\title{
Designing and Piloting a household filter for the peri-urban population of Douala (Cameroon)
}

\author{
Dissertation \\ zur Erlangung des mathematisch-naturwissenschaftlichen Doktorgrades \\ "Doctor rerum naturalium" \\ der Georg-August-Universität Göttingen \\ im Promotionsprogramm Geowissenschaften / Geographie \\ der Georg-August University School of Science (GAUSS)
}

vorgelegt von

TEPONG TSINDE, RAOUL

(M.Sc.-Ing, B. Sc.-Ing.)

Aus MBOUROUKOU, KAMERUN

Göttingen, 2020 


\section{List of advisers and examination committee}

\section{Betreuungsausschuss:}

- PD Dr. Chicgoua Noubactep, GZG - Abteilung Angewandte Geologie, Universität Göttingen

- Prof. Dr. Hans Ruppert, GZG - Abteilung Sedimentologie/Umweltgeologie, Universität Göttingen

\section{Mitglieder der Prüfungskommission}

\section{Referent:}

- PD Dr. Chicgoua Noubactep, GZG - Abteilung Angewandte Geologie, Universität Göttingen

\section{Koreferent:}

- Prof. Dr. Hans Ruppert, GZG - Abteilung Sedimentologie/Umweltgeologie, Universität Göttingen

\section{Weitere Mitglieder der Prüfungskommission:}

- Prof. Dr. Tobias Licha, AG Hydrogeochemie / Institut für Geologie, Mineralogie und Geophysik Fakultät für Geowissenschaften, Ruhr-Universität

- Prof. Dr. Achille NASSI, Lecturer, Electrochemical Laboratory, Faculty of Sciences, University of Douala, B.P.24157 Douala, Cameroon.

- Prof. Dr. Sebastian Vollmer, GZG - Abteilung, Entwicklungsökonomie / Centre for Modern Indian Studies (CeMIS), Universität Göttingen

- Prof. Dr. Rui Hu, School of Earth Science and Engineering, Hohai University, Fo Cheng Xi Road 8, 211100 Nanjing, P.R. China 


\section{Eidesstattliche Erklärung}

Ich gebe folgende Erklärung ab:

1. Die Gelegenheit zum vorliegenden Promotionsvorhaben ist mir nicht kommerziell vermittelt worden. Insbesondere habe ich keine Organisation eingeschaltet, die gegen Entgelt Betreuerinnen und Betreuer für die Anfertigung von Dissertationen sucht oder die mir obliegenden Pflichten hinsichtlich der Prüfungsleistungen für mich ganz oder teilweise erledigt.

2. Hilfe Dritter wurde bis jetzt und wird auch künftig nur in wissenschaftlich vertretbarem und prüfungsrechtlich zulässigem Ausmaß in Anspruch genommen. Insbesondere werden alle Teile der Dissertation selbst angefertigt; unzulässige fremde Hilfe habe ich dazu weder unentgeltlich noch entgeltlich entgegengenommen und werde dies auch zukünftig so halten.

3. Die Richtlinien zur Sicherung der guten wissenschaftlichen Praxis an der Universität Göttingen werden von mir beachtet.

4. Eine entsprechende Promotion wurde an keiner anderen Hochschule im In- oder Ausland beantragt; die eingereichte Dissertation oder Teile von ihr wurden nicht für ein anderes Promotionsvorhaben verwendet.

Mir ist bekannt, dass unrichtige Angaben die Zulassung zur Promotion ausschließen bzw. später zum Verfahrensabbruch oder zur Rücknahme des erlangten Grades führen.

Göttingen

(Ort)
$19 / 10 / 2020$

\section{(Unterschrift)}


"The scientific man does not aim at an immediate result. He does not expect his advanced ideas will be readily taken up. His work is like that of the planter ... for the future. His duty is to lay the foundation for those who are to come and to point the way. "

Nikola Tesla

"The Problem of Increasing Human Energy" (The Century Magazine, June, 1900) 


\section{Acknowledgements}

There are an uncountable number of people who supported me during this $\mathrm{Ph}$.D. study.

First and the foremost I would like to express my sincere gratitude to my supervisor PD. Dr. Chicgoua Noubactep. Thank you very much for valuable advice, fruitful discussions, and constant guidance all along this research work. Also, I fully acknowledge him the great freedom, the unconditional support during my several stays abroad, and the opportunity he gave me to seek and define my own research interests and apply them in this thesis. I owe him very much and my greatest thanks go to him because of his substantial contribution to my personal and professional development during these years being a good teacher, inspirer, and friend.

Loads and loads of thanks to my co-supervisor Prof. Dr. Hans Ruppert, for providing me with the best time I have ever had at the University of Göttingen. Your opinion, view, comments, and thoughts have been truly considered and appreciated along this time as Ph.D. student. I really appreciate the high standards you have set for me, which I would never have reached without your help.

I am particularly grateful to Prof. Dr. Achille Nassi of the University of Douala, who gave me the chance to spend these fabulous times of my research in Cameroon, in the beautiful city of Douala.

In this research work several people were involved during the development of some of the chapters/papers in which is comprised. I would like to express my gratitude to all of them.

Many thanks to my wife Tsadjeu Tsamo Mirabelle L. for her deep love and having braved all the difficulties to supervise our two sons Tsadjeu Tsinde Raoul and Manko Tsinde Nils Meyer during my long stay in Cameroon.

Last but not least, I should say thanks from the bottom of my heart to my beloved mother Manko Catherine, to my Father Tsinde Maurice, and my brothers (particularly Prof. Dr. Fokwa Tsinde B. P.) and sisters for their never-ending love, help, good food and unwavering support in so many ways through all this time. Thank you so much. 


\section{Dedication}

This project is dedicated to:

my parents and specially to my mother MANKO CATHERINE.

my lovely wife, my children,

for their endless love. 


\section{Abstract:}

In rural and peri-urban regions of the developing world, many tube wells used as drinking water sources are microbially and chemically polluted. Consequently, hundreds of millions of people lack access to "safe" drinking water worldwide. People drinking tube well water may suffer from preventable water-borne diseases including diarrhea, skin lesions, and cancer. To address this problem, the United Nations have launched the Sustainable Development Goals (UN SDGs) which are regarded as a global urgent call for action by all countries, in a global partnership. The UN SDGs for safe drinking water (Goal 6) aims to achieve universal water supply by 2030. This goal can only be achieved if affordable and efficient water treatment technologies are made available for households and small communities for simultaneous removal of chemicals and pathogens. Ideally, such systems should be constructed using locally available materials and labor. Filtration on metallic iron $\left(\mathrm{Fe}^{0}\right)$ based beds has been identified as such an appropriate technology and steel wool (SW) a universally available material. Moreover, $\mathrm{Fe}^{0}$-based filters have been designed and disseminated in some parts of the world but have not yet reached global applicability.

A critical review on the abundant literature on using $\mathrm{Fe}^{0}$-based filters for safe drinking water provision revealed that existing devices were not designed on the knowledge basis of the science of aqueous iron corrosion (corrosion science). Iron corrosion induces generation of solid iron corrosion products (FeCPs) which are well-documented contaminant scavengers. FeCPs consisting of Fe-oxide hydroxides are formed in the vicinity of the $\mathrm{Fe}^{0}$ surface and act as a diffusion barrier for dissolved species. Iron corrosion is additionally a volumetric expansive process because the volume of each oxide or hydroxide is at least twice larger than that of iron metal $\left(\mathrm{Fe}^{0}\right)$. These two main characteristics imply that (i) the efficiency of each $\mathrm{Fe}^{0}$-based filter depends on the kinetics of production of FeCPs (reactivity loss), and (ii) $\mathrm{Fe}^{0}-$ based filters will experience porosity loss with increasing service life (permeability loss). In other words, reactivity loss and permeability loss are inherent characteristics of $\mathrm{Fe}^{0}$-based filters which should be addressed in the design stage. Moreover, designed systems should be tested for months or years, given the incertitude on the kinetics of iron corrosion.

The objective of the present work was to design a science-based household filter and to test it for one year in the coastal city of Douala (Cameroon). The work started with a systematic review of available designs and a presentation of two main potentially durable designs. The one with a $\mathrm{Fe}^{0} /$ sand filter sandwiched between two biological sand filters (BSFs) was tested with polluted well water from Logpom (Douala, Cameroon) using $300 \mathrm{~g}$ of a commercial SW (grade 000; $\mathrm{d}=50 \mu \mathrm{m}$ ) as $\mathrm{Fe}^{0}$ source. Previous works using $\mathrm{Fe}^{0} \mathrm{SW}$ in water filters revealed 
that grade $00(\mathrm{~d}=25 \mu \mathrm{m})$ was depleted after some 6 months. The used well water was slightly turbid, polluted with pathogens (total coliforms $=1950 \mathrm{UFC} \mathrm{mL}^{-1}$ ), and contaminated with nitrate $\left(\left[\mathrm{NO}_{3}{ }^{-}\right]=24.0 \mathrm{mg} \mathrm{L}^{-1}\right)$. The following parameters were monitored twice per month for one year in the influent and effluent water of the filter unit: (i) nitrate concentration, (ii) coliform level, (iii) $\mathrm{pH}$ value, and (iv) turbidity. The iron concentration and the hydraulic conductivity (permeability) were also determined. Prior to pilot testing, the impact of chloride ions $\left(\mathrm{Cl}^{-}\right)$on the efficiency of $\mathrm{Fe}^{0}$ filters was characterized in laboratory column experiments, using the methylene blue discoloration method.

Results of laboratory column experiments revealed that the chloride concentrations expected in well waters in Douala would not negatively impact the efficiency of $\mathrm{Fe}^{0}$ filters. The tested design could produce safe drinking water for at least one year. Coliforms ( $>99 \%$ decrease), nitrate $(>99 \%)$ and turbidity $(>96 \%)$ were nearly quantitatively removed over the whole testing period and well below the recommended limits of the World Health Organization (WHO). The effluent $\mathrm{pH}$ increased continuously from 6.6 to 8.4. The effluent iron concentration was constantly lower than $0.2 \mathrm{mg} \mathrm{L}^{-1}$. These values are within the WHO drinking water quality standards. The initial flow velocity of $20 \mathrm{~L} \mathrm{~h}^{-1}$ decreased to $\sim 8.33 \mathrm{~L} \mathrm{~h}^{-1}$ after one year, corresponding to a permeability loss of nearly $41.5 \%$. At the end, the filter was still producing $200 \mathrm{~L}$ of drinking water

These results confirmed the suitability of commercial $\mathrm{Fe}^{0} \mathrm{SW}$ as efficient material to construct durable water filters for households. It appears that the success of the design relied on the low ratio of $\mathrm{Fe}^{0} \mathrm{SW}(10 \mathrm{vol} \%)$ dispersed in the matrix of sand (90 vol \%). The tested design can be immediately be applied practically, provide that appropriate construction materials are found. Future research should include (i) testing lower $\mathrm{Fe}^{0} \mathrm{SW}$ ratios (same grade), (ii) testing other grades of $\mathrm{Fe}^{0} \mathrm{SW}$ in parallel experiments (1 year or more); (iii) testing the same systems for the removal of arsenic and uranium which are the most widespread natural pollutants. $\mathrm{Fe}^{0} \mathrm{SW}$ based water filters can be considered as one of the best tools for the achievement of Goal 6 of the United Nations sustainable development goals (SDGs), despite the threat of COVID-19.

Keywords: $\mathrm{Fe}^{0}$-based filter; household filter; permeability loss, steel wool, zero-valent iron. 


\section{List of Papers:}

This doctoral thesis is based on three appended papers. These papers are equally referred below by their Roman numerals and DOI. In general, six papers were published during this thesis in which I was either main author or co-author.

1. Tepong-Tsindé R., Ndé-Tchoupé A.I., Noubactep C., Nassi A., Ruppert H. (2019): Characterizing a newly designed steel-wool-based household filter for safe drinking water provision: Hydraulic conductivity and efficiency for pathogen removal. Processes 7, 966. DOI: 10.3390/pr7120966

2. Tepong-Tsindé R., Phukan M., Nassi A., Noubactep C., Ruppert H. (2015): Validating the efficiency of the MB discoloration method for the characterization of $\mathrm{Fe}^{0} / \mathrm{H}_{2} \mathrm{O}$ systems using accelerated corrosion by chloride ions. Chemical Engineering Journal 279, 353-362. DOI: 10.1016/j.cej.2015.04.129

3. Tepong-Tsindé R., Crane R., Noubactep C., Nassi A., Ruppert H. (2015): Fundamentals for designing sustainable metallic iron-based filters for water treatment. Water 7, 868-897. DOI: 10.3390/w7030868

4. Ebelle T.C., Makota S., Tepong-Tsindé R., Nassi A., Noubactep C. (2016): Metallic iron and the dialogue of the deaf. Fresenius Environmental Bulletin 28 (11A), 83318340 .

5. Makota S., Ndé-Tchoupé A.I., Mwakabona H.T., Tepong-Tsindé R., Noubactep C., Nassi A., Njau K.N. (2017): Metallic iron for water treatment: leaving the valley of confusion. Appl Water Sci. 7, 4177-4196, DOI 10.1007/s13201-017-0601-x.

6. Arnaud Igor Ndé-Tchoupé*, Raoul Tepong-Tsindé, Mesia Lufingo, Zuleikha PembeAli, Innocent Lugodisha, Risala Iddi Mureth, Mihayo Nkinda, Janeth Marwa, Willis Gwenzi*, Tulinave Burton Mwamila, Mohammad Azizur Rahman, Chicgoua Noubactep, Karoli N. Njau. (2018): White teeth and healthy skeletons for all: The path to universal fluoride-free drinking water in Tanzania. Water 2018, 10, $\mathrm{x}$; DOI: 10.3390/w11010131 www.mdpi.com/journal/water 


\section{Table of content}

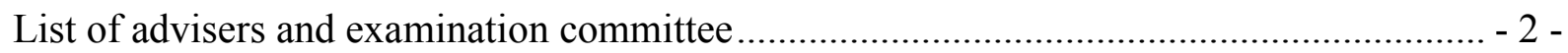

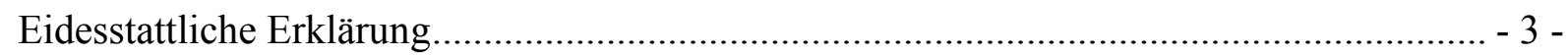

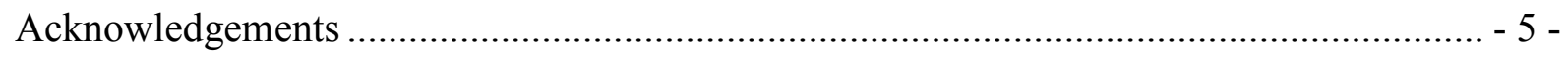

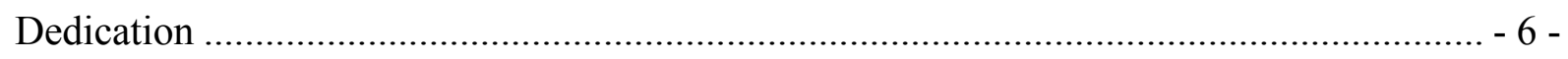

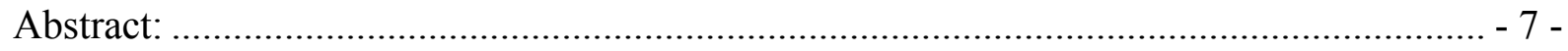

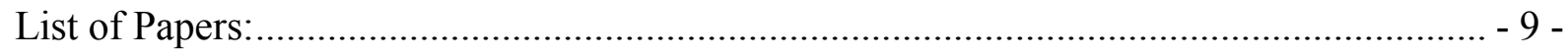

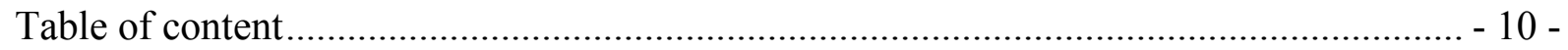

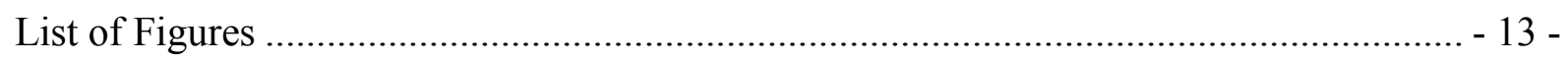

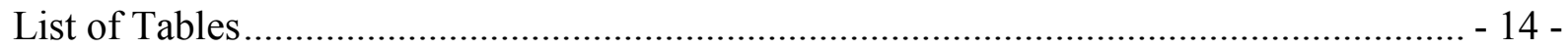

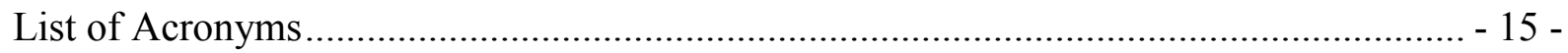

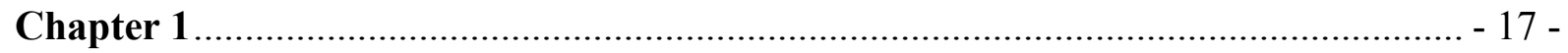

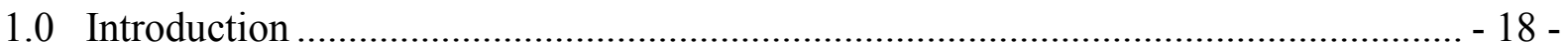

1.1 Access to safe drinking water in the developing world...................................... - 18 -

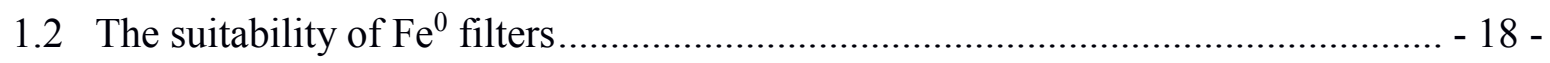

$1.3 \mathrm{Fe}^{0}$ materials for household filters ............................................................. 19 -

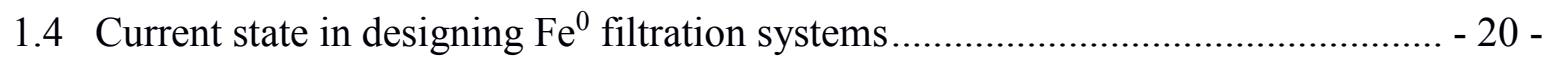

1.5 Access to safe drinking water in the peri-urban areas of Cameroon....................... - 21 -

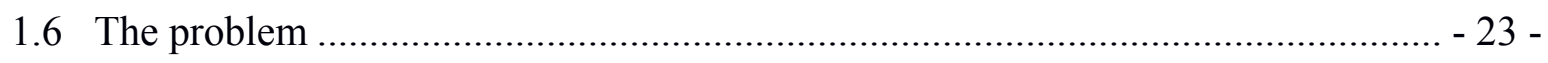

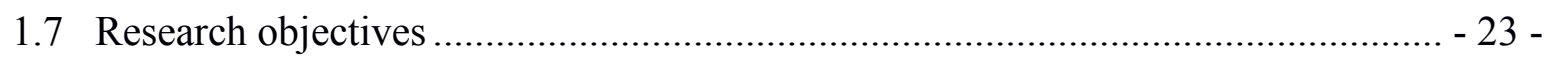

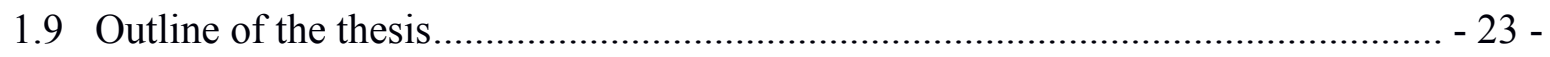

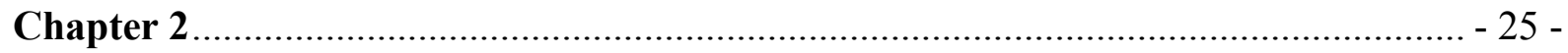

2.0 Preamble

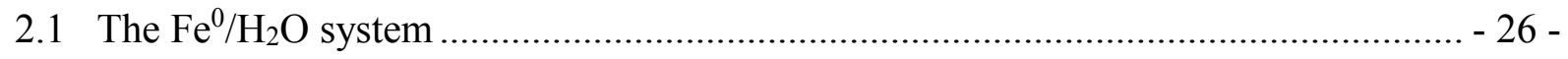

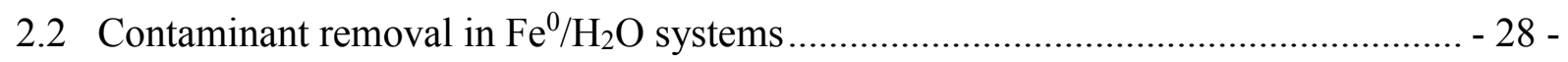

2.3 Testing $\mathrm{Fe}^{0}$-based filters for safe water provision ................................................. - 28 - 


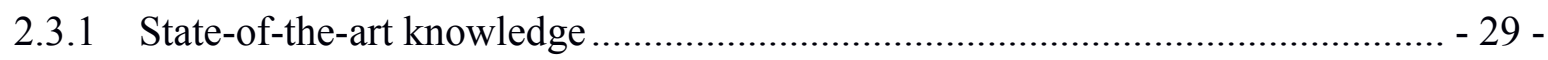

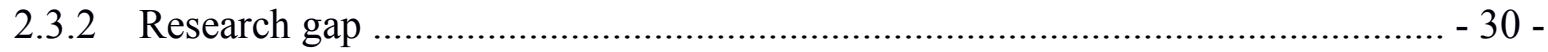

2.3.3 Research objective and research design .................................................... - 31 -

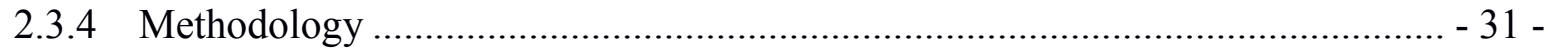

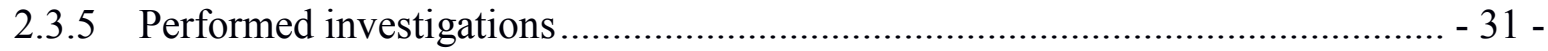

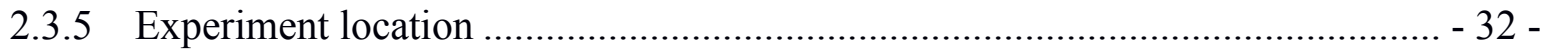

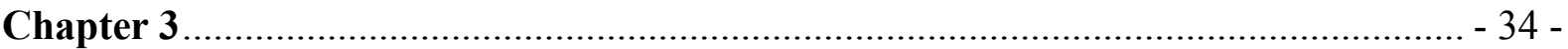

3.0 Preamble

3.1 The dynamic of the $\mathrm{Fe}^{0} / \mathrm{H}_{2} \mathrm{O}$ system and the $\mathrm{MB}$ method ....................................... $35-$

3.1.1 The conventional approach to investigate the $\mathrm{Fe}^{0} / \mathrm{H}_{2} \mathrm{O}$ system ........................ 36 -

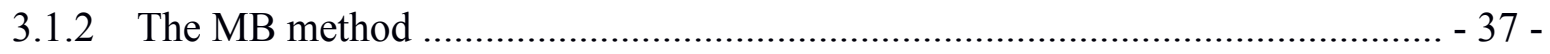

3.1.3 Past achievements of the MB method ............................................................... - 38 -

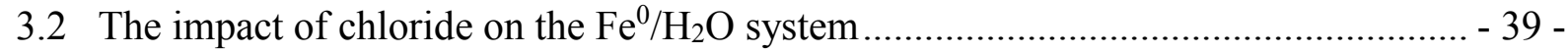

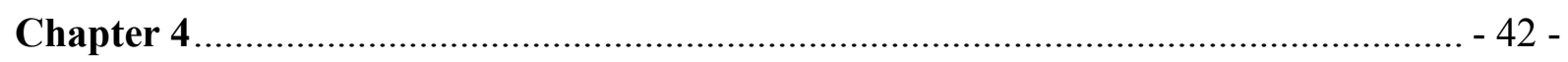

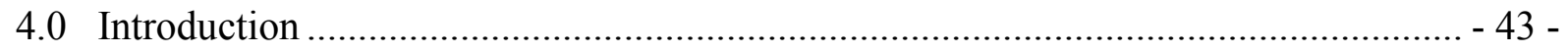

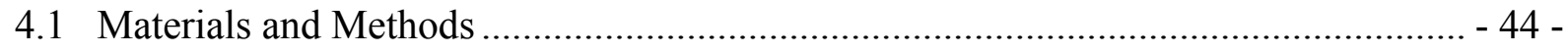

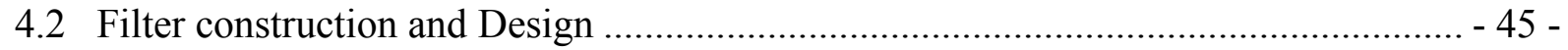

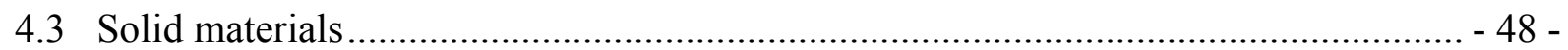

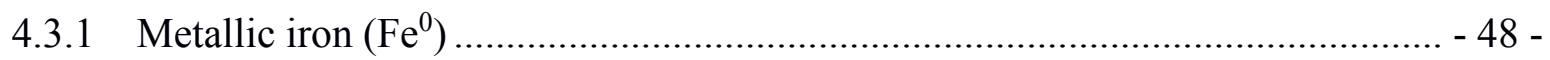

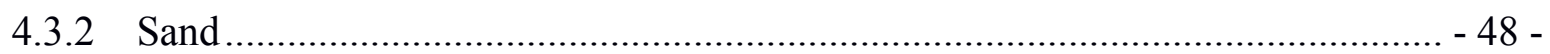

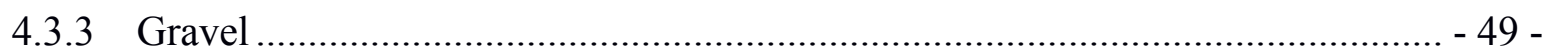

4.4 Construction protocol and guideline for the $\mathrm{Fe}^{0}$ based sand filter device.................. - 50 -

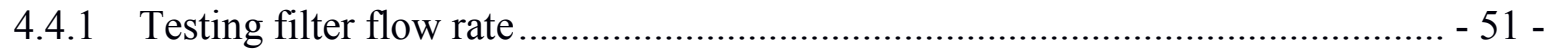

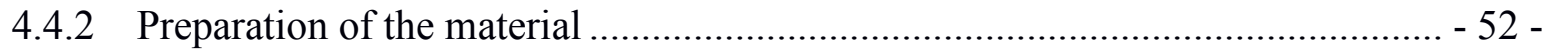

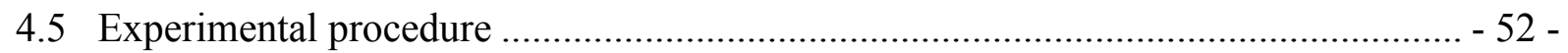

4.6 Sample collection and efficiency characterization ................................................ - 52 -

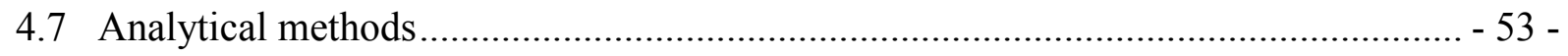

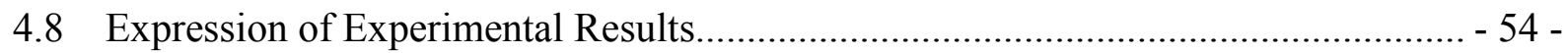

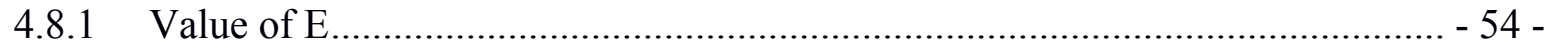

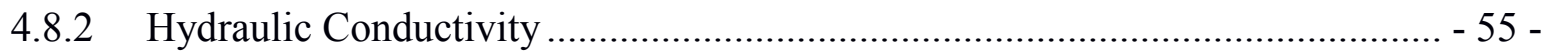




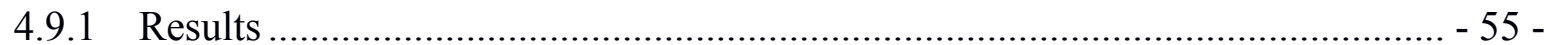

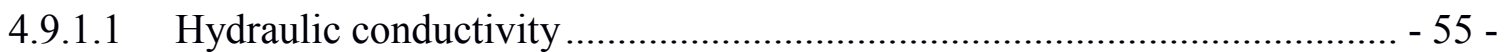

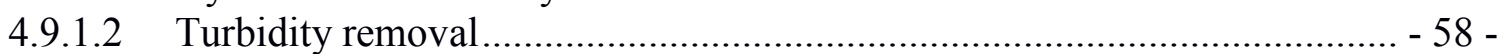

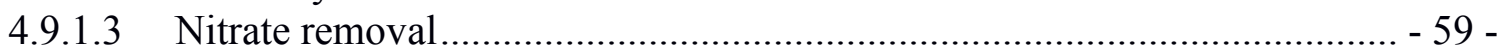

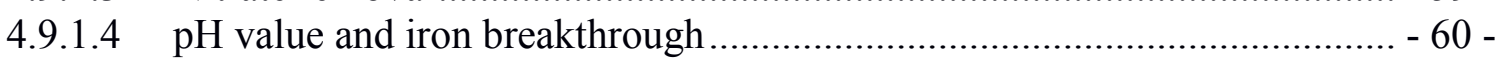

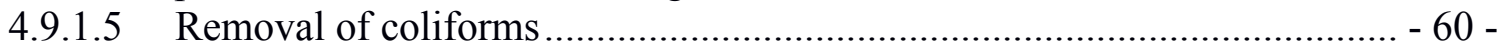

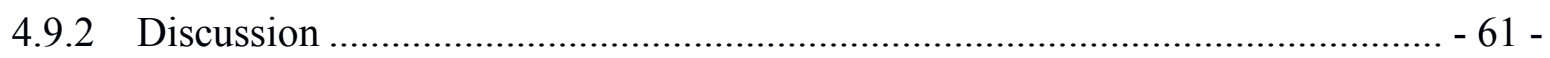

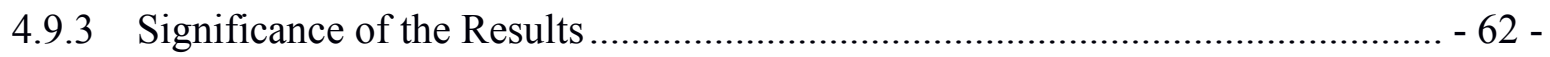

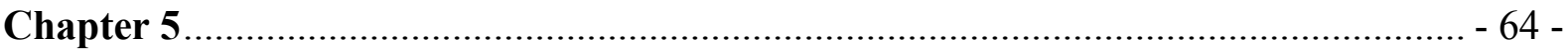

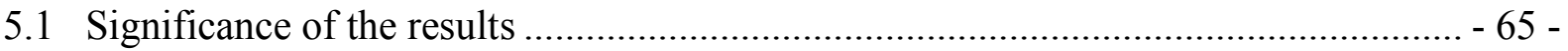

5.1.1 The validation of the MB discoloration method …......................................... - 66 -

5.1.2 Reasons for existing designs failure ............................................................. 67 -

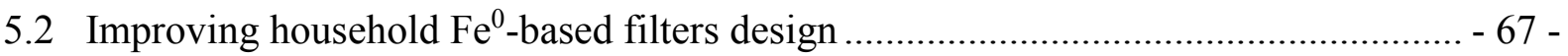

5.2.1 Considerations for efficient household $\mathrm{Fe}^{0}$-based on-site filters......................... - 67 -

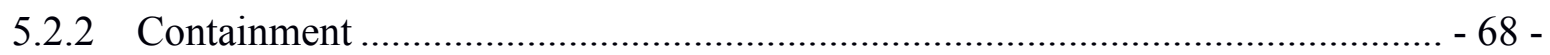

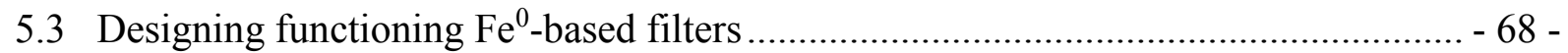

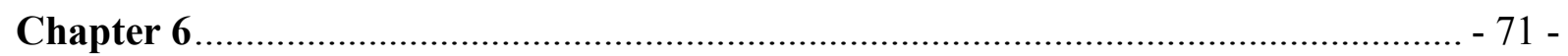

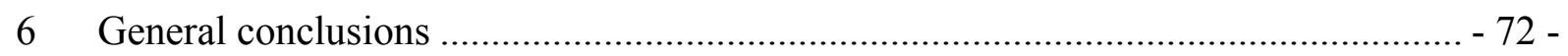

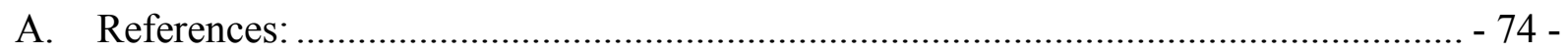

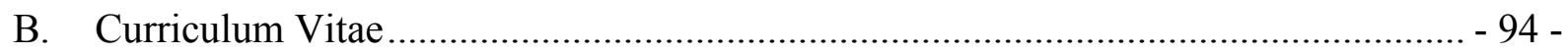

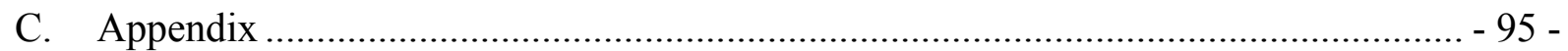




\section{List of Figures}

Figure 1: Evolution of percentage of households with access to safe drinking water in Douala and in Cameroon during the MDG era. (Source: Ako et al. 2010, modified). $-22-$

Figure 2: Location of water sources (well) in the study site (Douala Logpom). $-33-$

Figure 3: Photograph of a column design depicting the typical sequence of coloration described by Westerhoff and James (2003). The picture shows that the entrance zone of the $\mathrm{Fe}^{0} /$ sand zone is colored brown while the upper section is black. The sand layer after the $\mathrm{Fe}^{0}$ /sand zone more or less maintains its "white" / brownish color by $\mathrm{Fe}^{\mathrm{III}}$ iron oxide from the $\mathrm{Fe}^{0} /$ sand zone. Sand in the reference system (first column) and the sand layers preceding the $\mathrm{Fe}^{0} /$ sand zone are blue colored by methylene blue. (Picture from Miyajima 2012) -40 -

Figure 4: Picture of the designed filtration system: Well water was stored in blue $200 \mathrm{~L}$ tank. The first and the third columns are conventional bio sand filters (BSF). In the middle of column 2 is $\mathrm{Fe}^{0} \mathrm{SW}$ mixed with sand coarse (Picture B). The columns are connected to each other with a PET tube. $-45-$

Figure 5: Schematic diagram of the designed filtration system: Well water was stored in 200 L tank. The first and the third columns are conventional bio sand filters (BSF). In the middle of column 2 is $\mathrm{Fe}^{0} \mathrm{SW}$ mixed with coarse sand. The columns are connected to each other with a PET tube. -47 -

Figure 6: This step needed to sieve the grad of medium sand media. Sand coarse is maintained between $\mathrm{A}$ ( $2 \mathrm{~mm}$ in diameter) and $\mathrm{B}(0.63 \mathrm{~mm}$ in diameter). The sieve material for sieve A is a metal net and for the sieve B is the mosquito net. Each sieve is made with wooden frame. - 49 -

Figure 7: Scheme of the steps to obtain gravel with 4 to $8 \mathrm{~mm}$ diameter. A' is the first step of sieve to obtain gravel but the step B' is to eliminate all sand size contain in gravel from A'. The sieve materials in sieves A' and B' consist of metal wire meshes fixed in a wooden frame. - 49 -

Figure 8: Flow rate variation over the length of filter runs for the $\mathrm{Fe}^{0} \mathrm{SW}$ ratios of $50 \%$ and 10 vol.\% respectively. Experimental conditions: $800 \mathrm{~g} \mathrm{SW}$ for $50 \% \mathrm{Fe}^{0}$ and $300 \mathrm{~g} \mathrm{SW}$ for 10 $\% \mathrm{Fe}^{0}$ of $\mathrm{Fe}^{0} \mathrm{SW}$ (grade 0 ) of $35 \mu \mathrm{m}$ fiber thickness from "Grand Menage"; filling material: sand. Column length $100 \mathrm{~cm}$, column diameter $20 \mathrm{~cm}$. The system was fed with natural well water polluted by fecal coliforms. -57 -

Figure 9: Permeability loss (percent) of the filter material and efficiencies of the removal of fecal coliform, turbidity, and nitrate (percent) in the effluent water over the length of filter run for the experiment with $10 \% \mathrm{Fe}^{0} \mathrm{SW}$ (vol/vol). Experimental conditions: $300 \mathrm{~g} \mathrm{SW}$ at $26 \pm 2$ ${ }^{\circ} \mathrm{C}$; filling material: Sand; column length: $100 \mathrm{~cm}$, column diameter: $20 \mathrm{~cm}$. The system was fed by natural well water polluted by fecal coliform. -59 - 


\section{List of Tables}

Table 1: Summary of the used experimental set up. $H_{\text {gravel1 }}$ and $H_{\text {gravel2 }}$ are the heights of the underdrain and the upper layer respectively; $\mathrm{H}_{\text {sand1 }}$ the heights of medium sand; $\mathrm{H}_{\text {Sand } 1}$ is the medium sand layer (BSF) and $\mathrm{H}_{\mathrm{RZ}}$ is the height of the reactive layer $\left(\mathrm{Fe}^{\%} / \mathrm{sand}\right)$ sandwiched by $\mathrm{H}_{\text {sand2 }}$ $-47-$

Table 2: Average composition of the used well water. The well is polluted with coliforms and depicts high levels of conductivity and turbidity compared to the WHO guidelines (2017). WHO stands for World Health Organization. $-53-$

Table 3: Analytical method used in this study for physico-chemical and biological parameters $-54-$

Table 4: Characteristics of the effluent water over the testing period. The effluent iron concentration was constantly lower than the detection limit of the UV-Vis spectrophotometer $\left([\mathrm{Fe}]<0.2 \mathrm{mg} \mathrm{L}^{-1}\right) . \varphi$ is the water flow velocity in $\mathrm{L} \mathrm{h}^{-1}$ $-58-$

Table 5: Summary of parameters of column experiments for the removal of biological contamination compared with data from six selected peer-reviewed articles. - 62 - 


\section{List of Acronyms}

\begin{tabular}{|c|c|}
\hline $\mathrm{Fe}^{0}$ & Metallic iron \\
\hline UN & United nations \\
\hline SDG & Sustainable development goals \\
\hline $\mathrm{FeCP}$ & Iron corrosion product \\
\hline SW & Steel wool \\
\hline BSF & Biological sand filters \\
\hline $\mathrm{Cl}^{-}$ & chloride ions \\
\hline WHO & World health organization \\
\hline $\mathrm{pH}$ & Power of hydrogen \\
\hline CFU/UFC & Colony forming units \\
\hline $\mathrm{NO}_{3}^{-}$ & nitrate \\
\hline PET & PolyethyleneTerephthalate \\
\hline $\mathrm{Fe}^{\mathrm{II}} / \mathrm{Fe}^{2+}$ & Ferrous ion \\
\hline $\mathrm{Fe}^{3+}$ & Ferric ion \\
\hline$\mu \mathrm{mol}$ & micromole \\
\hline $\mathrm{mg} \mathrm{L}^{-1}$ & Milligrams per liter \\
\hline NTU & Nephelometric turbidity units \\
\hline $\mathrm{H}_{2}$ & Dihydrigen \\
\hline $\mathrm{HCO}_{3}^{-}$ & Hydrogencarbonate/Bicarbonate ion \\
\hline $\mathrm{PO}_{4}^{3-}$ & Phosphate ion \\
\hline MDG & Millennium development goals \\
\hline BSF & Biological sand filter \\
\hline Fig. & Figure \\
\hline RZ & Reactive zone \\
\hline $\mathrm{SO}_{4}{ }^{2-}$ & Sulfate ion \\
\hline Co & Cobalt \\
\hline $\mathrm{Cu}$ & Copper \\
\hline $\mathrm{Ni}$ & Nickel \\
\hline As & Arsenic \\
\hline $\mathrm{Cr}$ & Chromium \\
\hline PVC & Polyvinyl chloride \\
\hline Sec. & Seconde \\
\hline$\mu \mathrm{S} . \mathrm{cm}^{-1}$ & Microsencond per centimenter \\
\hline Tab. & Table \\
\hline $\mathrm{Cl}^{-}$ & Chloride ion \\
\hline MB & Methylene blue \\
\hline $\mathrm{MnO}_{2}$ & Manganese dioxide \\
\hline UV & Ultra violet \\
\hline ZVI & Zero-valent iron \\
\hline
\end{tabular}


-16 - 


\section{Chapter 1}

\section{Introduction}

This chapter corresponds to the introduction of the Thesis. 


\subsection{Introduction}

\subsection{Access to safe drinking water in the developing world}

Potable water is the most essential commodity on the earth for survival of human beings (Gleick 2000, Ali 2014). The availability of fresh water is decreasing continuously due to world population growth, increased use in agriculture, increased industrialization, and increased urbanization. Environmental, geological, and global changes are also continuously contaminating natural water resources (Gleick 2000, Shannon et al. 2008). As a consequence, the quality of an ever-increasing number of natural waters sources are no more safe for drinking purposes (Hussam and Munir 2007, Shannon et al. 2008, Etmannski et al. 2014, Ndé-Tchoupé et al. 2015). Therefore, the world community (including scientists and academicians) are working on affordable, applicable and efficient technologies for water treatment (Howe et al. 2012, Etmannski et al. 2014, Hering et al. 2016, Naseri et al. 2017, Nanseu-Njiki et al. 2019, Ogata et al. 2020, Huang et al. 2021a, Huang et al. 2021b, Mueller 2021, Mueller et al. 2021). The most important technologies for the water treatment are adsorption, coagulation, crystallization, distillation, oxidation, filtration, reverse osmosis, sedimentation and screening (Howe et al. 2012, Ali 2014). From these technologies, adsorption on fixed beds has been proven an easy to handle and affordable technology for low-income communities, including remote and scattered villages in the developing world (Hussam and Munir 2007, Noubactep et al. 2009, Noubactep et al. 2012, Ali 2014, Banerji and Chaudhari 2017, Bretzler et al. 2020, Ogata et al. 2020, Huang et al. 2021b, Mueller et al. 2021). Adsorption is also considered as one of the best wastewater treatment technologies due to its wide range of applications and ease of operation. During the past three decades, the scientific community has rediscovered metallic iron $\left(\mathrm{Fe}^{0}\right.$ also called zero-valent iron) as a powerful reactive material for water treatment on decentralized manner (Henderson and Demond 2007, Guan et al. 2015, Antia 2020, Cao et al. 2020, Hu et al. 2020, Yang et al. 2020, Huang et al. 2021b).

\subsection{The suitability of $\mathrm{Fe}^{0}$ filters}

Metallic iron $\left(\mathrm{Fe}^{0}\right)$ is a non-toxic and inexpensive reactive material that is readily available (Noubactep 2010, Gatcha-Bandjun et al. 2017, Antia 2020). Research over the last three decades has demonstrated the effectiveness of $\mathrm{Fe}^{0} /$ sand filter for the treatment of water contaminated physically (color, turbidity) (Tomizawa et al. 2016, Naidu and Birke 2015, Xiao et al. 2020a, Xiao et al. 2020b), chemically (dyes, anionic and cationic metal and metalloid ions, nitrogen compounds, radionuclides) (Heimann et al. 2018, Guan et al. 2015, Noubactep 
2015) and microbiologically (bacteria, viruses) (You et al. 2015, Ghauch 2015, Kim et al. 2021). The operating mode of $\mathrm{Fe}^{0}$ bed filters is based on the interactions between $\mathrm{Fe}^{0}$ in-situ generated corrosion products (example: $\mathrm{Fe}^{\mathrm{II}}, \mathrm{H}_{2}$, iron oxides and hydroxides) and water pollutants (Ndé-Tchoupé et al. 2015, Noubactep 2015, 2018, Xiao et al. 2020a, Xiao et al. 2020b). This knowledge was already familiar to the first designers of $\mathrm{Fe}^{0}$ filters about 150 years ago (Bischof 1873, 1877, 1878, Anderson 1883, 1884, 1885, Ogston 1885, Devonshire 1890, Mwakabona et al. 2017, Antia 2020, Noubactep 2020) but was little noticed since the 1990s (Guan et al. 2015, Naidu and Birke 2015). The application of the $\mathrm{Fe}^{0}$ technology for safe drinking water provision nearly 150 years ago contradicts the perception that this technology is recent or innovative (Devonshire 1890, Mwakabona et al. 2017, Antia 2020, Noubactep 2022). Despite its old age, there are not yet clear scientific design principles, which engineers can use to construct sustainable $\mathrm{Fe}^{0}$ filters on a site- and pollution-specific basis (Domga et al. 2015, Naseri et al. 2017, Noubactep 2018, Yang et al. 2020, Yang et al. 2021). Moreover, apart from sponge iron (Bischof 1873, Hussam and Munir 2007) no specific material for safe drinking water provision has been presented (Noubactep et al. 2005, Kim et al. 2014, Li et al. 2016, Hu et al. 2019, Li et al. 2019, Lufingo et al. 2019, Yang et al. 2020). The resolution of these two open issues would facilitate the conversion of existing knowledge of the science of aqueous corrosion of iron into an effectively practical solution for decentralized safe drinking water provision (Ndé-Tchoupé et al. 2015, Clasen et al. 2009, Noubactep et al. 2009, 2012, Tepong-Tsindé et al. 2015, Gatcha-Bandjun et al. 2017, Naseri et al. 2017, Noubactep 2018, Yang et al. 2020, Noubactep 2022). In other words, providing people with knowledge and tools to facilitate self-reliance in the supply of safe and healthy drinking water is an important goal (Shannon et al. 2008, Hering et al. 2016, Naseri et al. 2017, Noubactep 2018, Huang et al. 2021a).

\section{3 $\mathrm{Fe}^{0}$ materials for household filters}

A wide array of $\mathrm{Fe}^{0}$ materials have been tested and used as filters. Relevant materials include iron coils, iron composites (e.g. bimetallics), iron filings, iron nails, iron wire, scrap iron, nano-Fe ${ }^{0}$, sponge iron, and steel wool (Bischof 1877, Anderson 1886, Landis et al. 2001, Westerhoff and James 2003, Btatkeu-K et al. 2013, Lufingo et al. 2019). The reactivity of all these materials is characterized by the electrode potential of the redox couple $\mathrm{Fe}^{\mathrm{II}} / \mathrm{Fe}^{0}\left(\mathrm{E}^{0}=-\right.$ $0.44 \mathrm{~V}$ ). This implies that reactivity differences amount various $\mathrm{Fe}^{0}$ specimens are kinetic in nature. In fact, large differences in oxidation trends of $\mathrm{Fe}^{0}$ materials have been documented, even for materials from the same class (Landis et al. 2001, Btatkeu-K et al. 2013, Stefanoni et 
al. 2018, Li et al. 2019, Lufingo et al. 2019, Yang et al. 2020, Yang et al. 2021). It has therefore been posited that difficulties in comparing available results to each other is mostly due to differences in intrinsic reactivity (Noubactep et al. 2005, Btatkeu-K et al. 2013, Li et al. 2019, Lufingo et al. 2019). As an affordable and widely available material, steel wool ( $\mathrm{Fe}^{0}$ SW) has been largely tested for safe drinking water provision (Lauderdale and Emmons 1951, Bradley et al. 2011, Lufingo et al. 2019, Hildebrant 2018, George and Ahammed 2019) and wastewater treatment (James et al. 1992, Erickson et al. 2007, Erickson et al. 2017, Li et al. 2017).

There are seven grades of $\mathrm{Fe}^{0} \mathrm{SW}$ with filament widths varying from 10 to $90 \mu \mathrm{m}$ (Lufingo et al. 2019, Hildebrant et al. 2020). From these, only grade $000(\mathrm{~d}=25 \mu \mathrm{m})$ was tested in longterm experiments for water treatment and was depleted after 8 months. The present study tests grade $0(\mathrm{~d}=50 \mu \mathrm{m})$ to find out whether it will last for one year. One year is regarded as a reasonable duration to change filtration units and avoid the use of exhausted filters.

\subsection{Current state in designing $\mathrm{Fe}^{0}$ filtration systems}

$\mathrm{Fe}^{0}$ is an excellent material for water treatment in filtration systems (Gheju 2011, Ghauch 2015, Gheju 2018, Noubactep 2018). However, porosity decline due to the formation of expansive iron corrosion products and subsequent filter clogging is one of the major limitations to utilize such a system (Anderson 1886, Westerhoff and James 2003, Bartzas and Komnitsas 2010, Guan et al. 2015, Noubactep 2015, Yang et al. 2021). In order to prevent premature filter clogging (e.g. clogging occurs before $\mathrm{Fe}^{0}$ is exhausted), hybrid reactive zones (e.g. $\mathrm{Fe}^{0} / \mathrm{FeS}_{2}, \mathrm{Fe}^{0} / \mathrm{MnO}_{2}, \mathrm{Fe}^{0} /$ sand) have been recommended (Noubactep 2010, Noubactep and Care 2010, Noubactep 2011, Miyajima 2012, Noubactep 2012, Caré et al. 2013, Miyajima and Noubactep 2013, Ndé-Tchoupé et al. 2018). Because of its low cost and high availability, sand is a commonly used additive for this purpose ( $\mathrm{Bi}$ et al. 2009). $\mathrm{Fe}^{0} \mathrm{SW} / \mathrm{sand}$ filters for households are a promising class of cost-effective $\mathrm{Fe}^{0}$ amended sand filters which can be disseminated in remote communities (Bradley et al. 2011, George and Ahammed 2019, Hildebrant et al. 2020).

Despite almost seven decades of technical expertise on using $\mathrm{Fe}^{0} \mathrm{SW}$ in household water filters (Lauderdale and Emmons 1951, George and Ahammed 2019), available information is still weak for any rational design. The very first reason is that used materials were not characterized for their intrinsic reactivity (Noubactep et al, 2004, Noubactep et al, 2005, Li et al. 2019, Lufingo et al. 2019, Hu et al. 2021a). Some studies have not even specified the grade of used SW and the elemental composition is not specified as a rule (Nde-Tchoupe et al. 
2015, Hildebrant et al. 2020). However, as demonstrated by Lufingo et al. (2019), differences in the initial kinetics of $\mathrm{Fe}^{0} \mathrm{SW}$ dissolution in 1,10-Phenanthroline can be as large as factor 20. The second reason for the lack of design information is that available works have not always specified the used $\mathrm{Fe}^{0}$ :sand ratios and the thickness of the reactive zone (Hildebrant et al. 2020). To these two reasons, the use of column of different sizes, differences in experimental duration and in feeding water quality are further aggravating factors (Yang et al. 2020, Huang et al. 2021b). In particular, while the long-term kinetics of $\mathrm{Fe}^{0} \mathrm{SW}$ corrosion is certainly nonlinear (Nesic 2007, Lazzari 2008) and is yet to characterize in the context of water treatment, experimental duration exceeding four months are rare.

The following example illustrates the incompleteness of information regarding the design $\mathrm{Fe}^{0}$ SW/sand filters. Bradley et al. (2011) mixed $260 \mathrm{~g}$ of a Fe ${ }^{0} \mathrm{SW}$ (extra fine - Grade 000) with $1.563 \mathrm{~g}$ sieved sand (effective size $0.4 \mathrm{~mm}$ ) to form a $20 \mathrm{~cm}$-thick filter for virus removal over 300 days (10 months). The used $\mathrm{Fe}^{0} \mathrm{SW}\left(\mathrm{d}_{1}=25 \mu \mathrm{m}\right)$ was completely depleted after 170 days (8 months) but the system was still permeable. On the contrary, George and Ahammed (2019) tested a filter containing iron nails $\left(\mathrm{d}_{2}=2.0 \mathrm{~mm}\right)$ mixed with sand for just four months and did not consider the work of Bradley et al. (2011) in their discussion. Using larger particles $\left(\mathrm{d}_{2} / \mathrm{d}_{1}=80\right)$ and testing them for a shorter experimental duration $\left(\mathrm{t}_{1} / \mathrm{t}_{2}=2.5\right)$ is counterproductive, particularly in a context where long-term experiments are needed (Naseri et al. 2017, $\mathrm{Hu}$ et al. 2020, Yang et al. 2020, Huang et al. 2021b). There is a need to further investigate the relationship between SW proportion in a $\mathrm{Fe}^{0}$ filter, its long-term permeability, and its efficiency for water treatment.

\subsection{Access to safe drinking water in the peri-urban areas of Cameroon}

Cameroon has failed to meet the MDGs. Ako at al. (2010) noted that Cameroon is not yet on track to meet the targets of the MDGs for water and sanitation, but it has made notable progress since 1990. And Since 2015 the research work is orienting to the SDGs.

Figure 1 shows the comparative evolution of the percentage of household with access to a safe drinking water in the economic city of Douala and in Cameroon from 1990 to 2015.

It was established that in general, access to safe drinking water in Cameron decreased with a coverage rate of about 58\% in 1990 and a rate of about $48 \%$ in 2015. In Douala, the biggest and most populated city of Cameroon, there was a drop in its access rate from $45 \%$ in 1990 to about $22 \%$ in 2015 . 


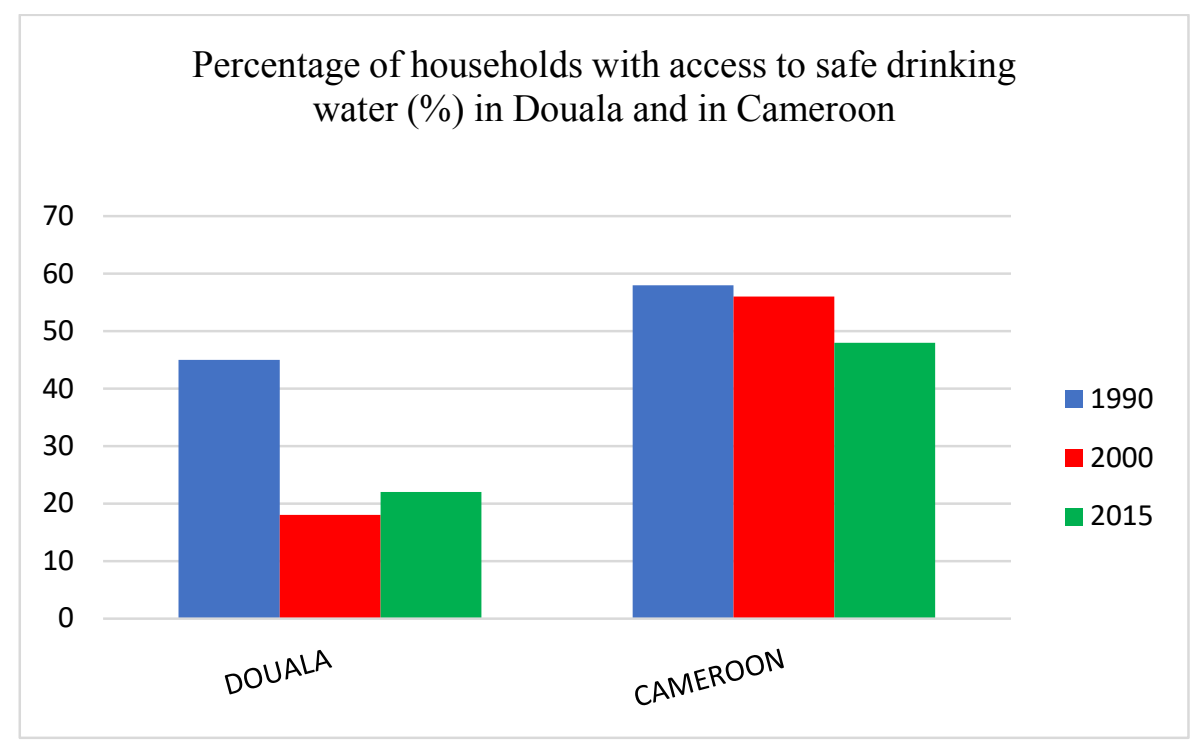

Figure 1: Evolution of percentage of households with access to safe drinking water in Douala and in Cameroon during the MDG era. (Source: Ako et al. 2010, modified).

From 1990 to 2000, country-wide there was a significant drop in access to potable water. This was attributed to the economic crisis of 1986-1993 in Cameroon which caused a significant reduction in public investments, therefore in the domain of water resources. For the Cameroon government to reach the 75 percent access rate it fixed by 2015, it had to increase access rate by 1.5 points per year (MINPLADAT, 2006). Instead from Figure 1, it is observed that the national access rate fell from about 58\% in 1990 to $56 \%$ in 2000 and then to about $49 \%$ in 2015. Based on this, Ako et al (2010) concluded that Cameroon will fail to reach the safe drinking water MDG target.

Due to poor planning and uncontrolled urbanization, peri-urban areas in Cameroon emerge spontaneously (Nya 2020, Nya and Mougoué 2020). Most of the inhabitants of the peri-urban areas are urban poor who cannot afford the cost of living in the city or rural people who move to the city in search of greener pastures as well as a few middle-class people. The absence of roads, water, electricity, housing, schools, and other services makes living in the peri-urban areas challenging (Fonjong and Fokum, 2017, Hope and Ballon 2019, Hope et al. 2020).

CAMWATER, the national water utility oversees production and distribution of potable water in urban areas of Cameroon while the Ministry of Water and Energy and NGOs supply the rural population (Ako et al., 2009, Nya 2020). CAMWATER is present in only $35 \%$ of Cameroonian cities and towns (Tanawa et al., 2002, Nya 2020). According to WHO (2008b), $82 \%$ of the Cameroon's urban population and $42 \%$ of the rural population are covered in terms of water supply with $23 \%$ of households having direct access to drinking water. Rapid urbanization in cities and towns has often rendered existing infrastructure inadequate, with 
frequent service interruptions and many peri-urban dwellers lacking access to safe drinking water. All this clearly indicates that the access to save drinking water in Cameroon for periurban population is difficult. This can be caused by the rural exodus, that can justify the proliferation of wells and rivers in peri-urban areas of the city of Douala.

\subsection{The problem}

Peri-urban area can be designed as a territory (or rather a set of territories) for which the inhabitants develop a feeling of identification or belonging, while maintaining links with the city, which provides them with jobs, goods and services. One of the main difficulties of these peri-urban areas is access to save drinking water. But these difficulties which hamper access to drinking water in homes are mainly linked to technical, social, legal, or governance resources (Hope and Ballon 2019, Nya 2020, Hope et al. 2020). So, the main problem is how to bring water to people in the peri-urban areas without need of electricity, without high maintenance and at a lower cost.

To solve this problem, a household $\mathrm{Fe}^{0} \mathrm{SW}$ water filter for the supply of people living in poor settlements in the developing world is designed and pilot tested. Natural well water from Logpom (Douala) was used for the experiments. The well water is polluted with coliforms, suspension, and contains up to $24 \mathrm{mg} \mathrm{L}^{-1}$ nitrate.

\subsection{Research objectives}

The goal of this thesis is to shape a practical application of $\mathrm{Fe}^{0} \mathrm{SW} /$ sand filter combination for household water purification. An important feature of the design is to treat contaminated water without any use of chemicals or electricity, but to provide a cheap, simple, and easily manageable device that brings clean drinking water into the reach of single dwellings in periurban and rural areas.

\subsection{Outline of the thesis}

In the chapter 1 (Introduction) of this thesis the theoretical background and application of existing $\mathrm{Fe}^{0}$-based filters are summarized. Chapter 2 describes the designing of $\mathrm{Fe}$ filters for small communities: An overview corresponds to the literature review and has already been published.

Chapter 3 investigates the impacts of chloride ions on the efficiency of $\mathrm{Fe}^{0}$ filters. This Chapter corresponds to the literature review and has also been published. The insights gained from the previous Chapters made it possible to carry out the designing and pilot-testing a 
household $\mathrm{Fe}^{0} \mathrm{SW}$ filter in Douala (Cameroon). This is the subject of Chapter 4. The results of the experiment are presented and discussed. The Chapter has been published.

Chapter 5 deals with general discussion and limitations.

The manuscripts of these publications are also included. Chapter 6 provides a general conclusion of this work and gives some suggestions for further research. The appendix includes the measurement data of most experiments, my curriculum vitae, a list of journal articles, and miscellaneous publications was compiled authored or co-authored by me and directly related to the presented work.

The cumulative nature of this thesis includes the papers published in the framework of this work.

Please note, that references are provided at the end of all chapters. 


\section{Chapter 2}

\section{Designing Fe ${ }^{0}$ filters for small communities: An overview}

This chapter corresponds to the literature review and has been published as:

Tepong-Tsindé R., Crane R., Noubactep C., Nassi A., Ruppert H. (2015): Testing metallic iron filtration systems for decentralized water treatment at pilot scale. Water 7, 868-897. 


\subsection{Preamble}

During the past five years, some important innovations were made available which can be summarized in two key points: (i) the ancient technology of using metallic iron $\left(\mathrm{Fe}^{0}\right)$ for safe drinking water was rediscovered (Mwakabona et al. 2017, Antia 2020), and (ii) new articles validating the 2015 designs (Tepong-Tsindé et al. 2015) were published (Etmannski 2014, Etmannski and Darton 2014, Casentini et al. 2016, Smith et al. 2017, Ahmed et al. 2018, Abbas et al. 2018, Bretzler et al. 2020). The net result is that new $\mathrm{Fe}^{0}$ filter designs co-exist with old ones, while a critical literature review consolidating available information is yet to be written (Yang et al. 2021). Therefore, this chapter is not only giving an overview of the appended Tepong-Tsindé et al. (2015), but rather a general overview of the 170 years of using metallic iron for safe drinking water provision. The presentation will start with the chemistry of the $\mathrm{Fe}^{0} / \mathrm{H}_{2} \mathrm{O}$ system.

\subsection{The $\mathrm{Fe}^{0} / \mathrm{H}_{2} \mathrm{O}$ system}

When a reactive piece of $\mathrm{Fe}^{0}$ is immersed in water, its oxidative dissolution is spontaneous. This occurs because the electrode potential of the redox couple $\mathrm{H}_{2} \mathrm{O} / \mathrm{H}_{2}$ or $\mathrm{H}^{+} / \mathrm{H}_{2}\left(\mathrm{E}^{0}=0.00\right.$ $\mathrm{V}$ ) is higher than that of $\mathrm{Fe}^{\mathrm{II}} / \mathrm{Fe}^{0}\left(\mathrm{E}^{0}=-0.44 \mathrm{~V}\right.$ ) (Whitney 1903, Landolt 2007, Groysman 2010). The corresponding electrochemical reaction is given by Equation 2.1:

$$
\begin{aligned}
& \mathrm{Fe}^{0}+2 \mathrm{H}_{2} \mathrm{O} \Rightarrow \mathrm{Fe}^{2+}+2 \mathrm{OH}^{-}+\mathrm{H}_{2} \\
& \mathrm{Fe}^{0}+2 \mathrm{H}^{+} \Rightarrow \mathrm{Fe}^{2+}+\mathrm{H}_{2} \\
& \mathrm{Fe}^{0}+2 \mathrm{H}_{2} \mathrm{O} \Rightarrow \mathrm{Fe}(\mathrm{OH})_{2}+\mathrm{H}_{2}
\end{aligned}
$$

Equation 2.1a specifies that oxidizing protons $\left(\mathrm{H}^{+}\right)$from water dissociation are the real oxidizing agents. Equation $2.1 \mathrm{~b}$ recalls that one mole $\mathrm{Fe}^{2+}$ is combined with 2 moles of $\mathrm{OH}^{-}$ to form one mole of $\mathrm{Fe}(\mathrm{OH})_{2}$ which polymerizes and precipitates in the vicinity of the $\mathrm{Fe}^{0}$ surface (Nesic 2007, Lazzari 2008, Groysman 2010, Noubactep 2010a, Cao et al. 2020, Noubactep 2022).

As reaction after Equation $2.1 \mathrm{~b}$ proceeds, $\mathrm{Fe}(\mathrm{OH})_{2}$ may disproportionate to magnetite and $\mathrm{H}_{2}$ according to the Schikorr reaction (Equation 2.2) (Beverskog and Puigdomenech 1996, Qin et al. 2018).

$$
3 \mathrm{Fe}(\mathrm{OH})_{2} \Rightarrow \mathrm{Fe}_{3} \mathrm{O}_{4}+2 \mathrm{H}_{2} \mathrm{O}+\mathrm{H}_{2}
$$

Combining Equation 2.1b and Equation 2.2 yields to Equation 2.3: 


$$
3 \mathrm{Fe}^{0}+4 \mathrm{H}_{2} \mathrm{O} \Rightarrow \mathrm{Fe}_{3} \mathrm{O}_{4}+4 \mathrm{H}_{2}
$$

Equation 2.3 reveals that the oxidation of 3 moles of $\mathrm{Fe}^{0}$ releases 4 moles of $\mathrm{H}_{2}$. In other words, the overall stoichiometry of $\mathrm{H}_{2}$ production from $\mathrm{Fe}^{0}$ varies from 1:1 (Equation 2.1) to 4:3 (Equation 2.3) (Reardon 1995, Reardon 2005, Velimirovic et al. 2013, Qin et al. 2018). The reaction shown in Equation 2.1 is the stoichiometrically dominant reaction under anoxic conditions $\left(\mathrm{O}_{2}\right.$ free). However, even under oxic conditions, Equation 2.1 is the sole path for iron corrosion because the in-situ generated oxide film acts as a diffusion barrier for dissolved species (including $\mathrm{O}_{2}$ ) (Whitney 1903, Stratmann and Müller 1994) and a conduction barrier for electrons from the metal body ( $\mathrm{Hu}$ et al. 2019a, Noubactep 2022). In the recent remediation literature, it has been largely considered that reducible contaminants compete with water for $\mathrm{Fe}^{0}$ oxidation (Liu et al. 2013, Qui et al. 2018, He et al. 2020, Hu et al. 2021b). The electron efficiency concept will not be discussed herein. Interested readers are referred to the excellent recent review article by $\mathrm{He}$ et al. (2020). For the presentation in this dissertation, it suffices to consider that each oxidized mole of $\mathrm{Fe}^{0}$ potentially yields one mole of $\mathrm{Fe}(\mathrm{OH})_{2}$ or other iron hydroxides (e.g. $\left.\mathrm{Fe}(\mathrm{OH})_{3}\right)$ and oxides (e.g. $\mathrm{Fe}_{2} \mathrm{O}_{3}, \mathrm{Fe}_{3} \mathrm{O}_{4}$ ) that are all larger in volume than the parent iron $\left(\mathrm{Fe}^{0}\right)$ : $\mathrm{V}_{\text {oxide }}>\mathrm{V}_{\text {iron }}$.

The expansive nature of metal corrosion was described in the 1920s (Pilling and Bedworth 1923, Caré et al. 2008) and first considered in the $\mathrm{Fe}^{0}$ remediation literature only a decade ago (Noubactep 2011, Caré et al. 2013, Domga et al. 2015). The key issue of the volumetric expansion of iron corrosion is that the process which is put into use (iron corrosion) is the first cause of permeability loss of $\mathrm{Fe}^{0}$-based filters. Accordingly, pure $\mathrm{Fe}^{0}$ filters $\left(100 \% \mathrm{Fe}^{0}\right)$ can be efficient but never sustainable. This pure physical consideration rationalizes the need of using hybrid systems (e.g. Fe\%sand) to design sustainable systems (Noubactep et al. 2011, Nanseu-Njiki et al. 2019, Yang et al. 2020, Yang et al. 2021). During the past decade, Noubactep and colleagues have developed a facile method to characterize the reactivity of the $\mathrm{Fe}^{0} / \mathrm{H}_{2} \mathrm{O}$ system: The methylene blue method or $\mathrm{MB}$ method (Chapter 3 ). Using the $\mathrm{MB}$ method Miyajima (2012) and Btatkeu-K (2015) have demonstrated that sustainable filters should contain less than $50 \%(\mathrm{vol} / \mathrm{vol}) \mathrm{Fe}^{0}$. These experiments have validated theoretical predictions by Togue-Kamga (2013) and rationalized observations by several authors, that some systems with less $\mathrm{Fe}^{0}$ performed better than pure $\mathrm{Fe}^{0}$ systems as summarized in TepongTsindé et al. (2015).

For $\mathrm{Fe}^{0} \mathrm{SW}$ used in water treatment, there are investigations with $100 \% \mathrm{Fe}^{0}$ (Lauderdale and Emmons 1951, Hildebrant 2018) and some few with up to $5 \%$ (Wakatsuki et al. 1993, Erickson et al. 2007, 2017, Latrach et al. 2018). Only Bradley et al. (2011) have worked with 
$10 \% \mathrm{Fe}^{0} \mathrm{SW}$. Accordingly, the range 5 to $50 \% \mathrm{Fe}^{0} \mathrm{SW}$ is largely unexplored. This work was also designed to contribute to fill this knowledge gap.

\subsection{Contaminant removal in $\mathrm{Fe}^{0} / \mathrm{H}_{2} \mathrm{O}$ systems}

The evidence that iron corrosion is volumetric expansive implies that in filtration beds, available pores are filled with in-situ generated solid corrosion products (FeCPs) (Yang et al. 2020, Yang et al. 2021). This also implies that contaminant removal by size-exclusion is improved with increasing service life, at least as long as the filter is still permeable. This predictable result has been observed in several systems (Westerhoff and James 2003, Hussam 2009, Tepong-Tsindé et al. 2015, Guan et al. 2015). Noubactep (2010, 2011) has demonstrated that the described volumetric expansion is factually a cycle of expansions and compressions going through the colloid phase and implying contaminant enmeshment (coprecipitation). In other words, a species entering a $\mathrm{Fe}^{0} / \mathrm{H}_{2} \mathrm{O}$ system can be (i) adsorbed onto aged FeCPs, (ii) co-precipitated by nascent FeCPs or (iii) be removed by pure size-exclusion. Contaminant removal by adsorption and co-precipitation corresponds to the operating mode of coagulation/flocculation and was known by Gustav Bischof already (Bischof 1873, Anderson 1883). In the Bischof Process, $\mathrm{Fe}^{0}$ (sponge iron) was used to remove pathogens and color from river waters (Antia 2020). In the design of Lauderdale and Emmons (1951), $\mathrm{Fe}^{0}$ in the form of steel wool was also used to generate scavengers of radionuclides. After 1990 and the advent of $\mathrm{Fe}^{0}$ permeable reactive barriers, $\mathrm{Fe}^{0}$ was used for the first time to selectively remove contaminant by (i) a reductive mechanism (e.g. $\mathrm{Cr}, \mathrm{Cu}$ ), (ii) an adsorptive mechanism (e.g. As), (iii) by co-precipitation (e.g. As) or a synergy of several mechanisms. However, the abundance of water (the solvent) and the spontaneous nature of Equation 2.1 implies that $\mathrm{Fe}^{0}$ oxidation by a contaminant is not likely to occur. Thus, $\mathrm{Fe}^{0}$ should be regarded as a generator of contaminant scavengers, regardless from the redox properties of the contaminants (Gheju 2011, Ghauch 2015, Gheju 2018). It follows that, a key question to answer while designing $\mathrm{Fe}^{0} / \mathrm{H}_{2} \mathrm{O}$ systems is: What is the long-term kinetics of generation of contaminant scavengers? In other words, which parameters should be considered for the design of efficient and sustainable $\mathrm{Fe}^{0}$ filters?

\subsection{Testing $\mathrm{Fe}^{\mathbf{0}}$-based filters for safe water provision}

Already during the $19^{\text {th }}$ Century, it was acknowledged that designing a water filter is a complex issue that is possibly surrounded with "much ignorance and misapprehension" 
(Notter 1878). The reactive nature of $\mathrm{Fe}^{0}$ and its nonlinear corrosion kinetics are further aggravating factors (Moraci et al. 2016, Noubactep 2016, Qin et al. 2018). The success of any filter depends on at least four groups of variables: (i) the quality of raw water (e.g. $\mathrm{pH}$, salinity, extent of contamination), (ii) the quality and volume of water to produce by unit time (e.g. daily), (iii) the speciation of the contaminants of concern (e.g. $\mathrm{As}^{\mathrm{III}}$ or $\mathrm{As}^{\mathrm{V}}$ ), (iv) the characteristics of used $\mathrm{Fe}^{0}$ and admixing aggregates. Relevant characteristics of $\mathrm{Fe}^{0}$ include its size, form, surface state, intrinsic reactivity and storing conditions or pre-treatment.

Rationally designing a water filter implies combining the named variables to determine the $\mathrm{Fe}^{0}$ amount (mass), its proportion in the mixture (e.g. $10 \% \mathrm{vol} / \mathrm{vol}$ ), the thickness of the reactive zone, and the service life of the filter in satisfactorily treating a given polluted water. Given that each water source, each $\mathrm{Fe}^{0}$ and each $\mathrm{Fe}^{0}$ /aggregate combination are unique, there is an infinite number of possible filters capable at efficiently treating any polluted water. All is needed is a systematic testing program and the readiness for long term experiments (Naseri et al. 2017, Nanseu-Njiki et al. 2019, Yang et al. 2020).

\subsubsection{State-of-the-art knowledge}

The current state-of-the-art knowledge on designing $\mathrm{Fe}^{0} / \mathrm{H}_{2} \mathrm{O}$ systems is excellently summarized in a recent publication by Antia (2020). As far as drinking water is concerned, there is an expanded use of small-scale $\mathrm{Fe}^{0}$ reactors for households and small communities (Hussam 2009, Banerji and Chaudhari 2017, Bretzler et al. 2020). Treated water sources are mostly wells and tube wells, mostly in regions without municipal water treatment infrastructures. The current production capacity for small communities is 150,000 to 250,000 $\mathrm{m}^{3} \mathrm{~d}^{-1}$ (Antia 2020). $\mathrm{Fe}^{0} / \mathrm{H}_{2} \mathrm{O}$ systems have also been discussed for their suitability to produce potable water for emergency relief (Noubactep et al. 2009, Antia 2020). The potential global commercial market for $\mathrm{Fe}^{0}$-based technologies is huge, but its current coverage is rather very small. If the technology can be downscaled to meet the needs of individual households, then its future global commercial market may exceed any actual predictions.

To meet the needs of households on a global level, the first issue is to find a suitable $\mathrm{Fe}^{0}$ material (Btatkeu-K 2015, Ndé-Tchoupé 2019). Steel wool and iron nails are currently the most used (Nanseu-Njiki et al. 2019). However, their intrinsic reactivity has not been characterized (Hu et al. 2019b, Hu et al. 2019c, Lufingo et al. 2019, Hildebrant et al. 2020). Our research group has tested several classes of $\mathrm{Fe}^{0}$ materials (Btatkeu-K 2015, Ndé-Tchoupé 2019) before opting for steel wool. The rationale for this choice is the tiny size of the filaments $(<100 \mu \mathrm{m})$ and the probability of their depletion under field applications. The 
hypothesis is supported by results from Bradley et al. (2011) reporting on the depletion of $\mathrm{Fe}^{0}$ SW grad $000(\mathrm{~d}=25 \mu \mathrm{m})$ after 6 months in their experiments. $\mathrm{Fe}^{0} \mathrm{SW}$ grade $0(\mathrm{~d}=50 \mu \mathrm{m})$ was tested herein.

The most efficient $\mathrm{Fe}^{0}$ materials for water treatment in filters over the decades are porous ones (Bischof 1873, Hussam 2009). Contrary to compact materials (e.g. iron filings, iron nails, scrap iron) they are likely to be extensively corroded under natural conditions. This is because the "extraction" of iron from deeper layers of compact materials is uncertain in the long term ('reactivity loss'). Once a $\mathrm{Fe}^{0}$ material is selected for the construction of a filter, an appropriate arrangement of the materials should be sought (Tepong-Tsindé et al. 2015).

\subsubsection{Research gap}

The literature on $\mathrm{Fe}^{0}$ household filters until 2014 (start of this work) was full of different designs of which only the SONO filters were sustainable (Neumann et al. 2013, Wenk et al. 2014). Devices for small communities were rare and long-term experience was similarly missing (Gottinger et al. 2013, Chaudhari et al. 2014, Kowalski and Søgaard 2014). Caré et al. (2013) justified the success of SONO filters by the porous nature of the used $\mathrm{Fe}^{0}$-based composite. However, the system was patented and thus not universally accessible. The calculations of Caré et al. (2013) demonstrated that admixing $\mathrm{Fe}^{0}$ and non-expansive aggregates would result in efficient and sustainable systems.

The science-based hypothesis of Caré et al. (2013) was in frontal contradiction with the then prevailing view that $\mathrm{Fe}^{0} /$ sand mixture are best used as $\mathrm{O}_{2}$ scavenger pre-treatment layers to enable anoxic systems where contaminants are reduced by electrons from $\mathrm{Fe}^{0}$, non-disturbed by dissolved $\mathrm{O}_{2}$ (Mackenzie et al. 1999, Westerhoff and James 2003, Henderson and Demond 2007). Fortunately, some researchers had used $\mathrm{Fe}^{0} /$ sand column to treat water (Khan et al. 2000, Lackovic et al. 2000). In particular, Khan et al. (2000) used $\mathrm{Fe}^{0}$ to in-situ increase aqueous iron concentration and induce As co-precipitation. In other words, a $\mathrm{Fe}^{0} / \mathrm{sand}^{\mathrm{mix}} \mathrm{mure}$ cannot be regarded as a pre-treatment zone. The open question was how long such a mixture can efficiently treat water? One partial answer was that, under oxic conditions, filter clogging is more likely because larger corrosion products are generated (Domga et al. 2015). In other words, creating conditions of low $\mathrm{O}_{2}$ concentrations is a tool to sustain the service life of $\mathrm{Fe}^{0}$ filters.

The conventional water treatment system suggests that a low-cost way to consume dissolved $\mathrm{O}_{2}$ from water is to let it flow through a slow sand filter (SSF) (Campos 2002, Haig et al. 2011), of which a miniature version is available and termed as biological sand filter (BSF) 
(Lea 2008). Accordingly, a BSF preceding a $\mathrm{Fe}^{0} /$ sand filter would result in a more sustainable system. Given that $\mathrm{Fe}^{0}$ alone, sand alone and $\mathrm{Fe}^{0} /$ sand systems were already compared for water treatment efficiency and the superiority of $\mathrm{Fe}^{0} /$ sand systems demonstrated (Miyajima 2012, Phukan 2016) that the discussion was limited to the design of $\mathrm{Fe}^{0} /$ sand systems. The main operational variable is the $\mathrm{Fe}^{0}$ :sand ratio. Based on previous works in Cameroon, commercial steel wool ( $\mathrm{SW}$ ) was used as $\mathrm{Fe}^{0}$ source. The rationale of using $\mathrm{Fe}^{0} \mathrm{SW}$ was that given their tiny diameters $(\mu \mathrm{m})$ compared to granular materials $(\mathrm{mm})$ there is a chance that they are exhausted in a test. Moreover, Bradley et al. (2011) had already experienced the depletion of extra-fine SW $(\mathrm{d}=25 \mu \mathrm{m})$.

\subsubsection{Research objective and research design}

The objective of the paper was to make recommendations based on the current state of the science concerning (i) aqueous iron corrosion and (ii) contaminant removal by iron oxides/hydroxides in the environment. Tested SONO-like with grade $0 \mathrm{SW}(\mathrm{d}=50 \mathrm{~mm})$ using well water for one year in Douala is the specific objective of this work.

One objective of the research has been to design a long-lasting drinking water filter for coastal regions with fluctuating salt intrusion into the aquifer.

\subsubsection{Methodology}

The technical steps to realize a water purification unit are: (i) developing, as a prelude to the pragmatic laboratory tests, a concept for the dimensioning of such filters; (ii) characterize and rationalize the suitability of the $\mathrm{Fe}^{0}$-material for the construction and the guideline of the $\mathrm{Fe}^{0}$ Filter; (iii) solve the well-known clogging (loss of permeability) problem of $\mathrm{Fe}^{0}$ bed filters; (iv) test the applicability and effectiveness of $\mathrm{Fe}^{0}$ filters for domestic use.

In this thesis, the production of quality drinking water by removing dissolved iron, nitrate, turbidity, and pathogens from influent water could successfully be accomplished.

\subsubsection{Performed investigations}

In the framework of this dissertation, experimental research has been carried out in two domains: (i) characterizing the effects of chloride on the efficiency of $\mathrm{Fe}^{0} / \mathrm{H}_{2} \mathrm{O}$ systems (Chapter 3), and (ii) testing a steel wool-based household filter for safe drinking water provision in Douala, Cameroon (Chapter 4). 


\subsubsection{Experiment location}

The field experiments were conducted in the peri-urban area of the city of Douala in Cameroon's Littoral Region. Douala is located between $4^{\circ} 04^{\prime}$ Nord latitude and $9^{\circ} 45^{\prime}$ Est longitude, $13 \mathrm{~m}$ above sea level, it is directly at the estuary of Wouri River which discharges into the Atlantic (Direct in the Gulf of Guinea). The Wouri River is at least brackish. The city and its surrounding area had an estimated population of 3638237 in 2019. Douala is divided into five districts. The region has a humid equatorial climate which is characterized by a long rainy season from April to October and a short dry season from November to March (Suchel 1988). The peak rainfall occurs from July to September. The average annual rainfall is around $4.000 \mathrm{~mm}$. The annual temperature is between $23^{\circ} \mathrm{C}$ and $33^{\circ} \mathrm{C}$ (average $27^{\circ} \mathrm{C}$ ), January and February being the hottest months of the year. The ferralitic soils of the area vary from yellow through brown to black, freely drained and are sandy, while being sandier at the top and more sandy clayey in the subsoil (Asaah et al. 2006). The groundwater table is generally located less than $10 \mathrm{~m}$ below the surface (Mafany et al. 2006), the aquifer being continuously recharged by rainfalls. Wastewater from drainage channels also infiltrates into this aquifer. Several streams run in the area and may recharge the aquifer depending on season and water level. The fluctuations of the average groundwater levels range from 0.3 to 2.1 meter between the dry and wet seasons.

Given its coastal location, it seems theoretically possible, that upon excessive groundwater extraction, seawater intrusion may occur in the more coastal areas of Douala (Mafany et al. 2006). To account for slightly saltwater affected groundwaters, the influence of chloride $\left(\mathrm{Cl}^{-}\right)$ on the cleaning efficiency of the $\mathrm{Fe}^{0} / \mathrm{H}_{2} \mathrm{O}$ system is also characterized in this thesis (chapter $3)$. 


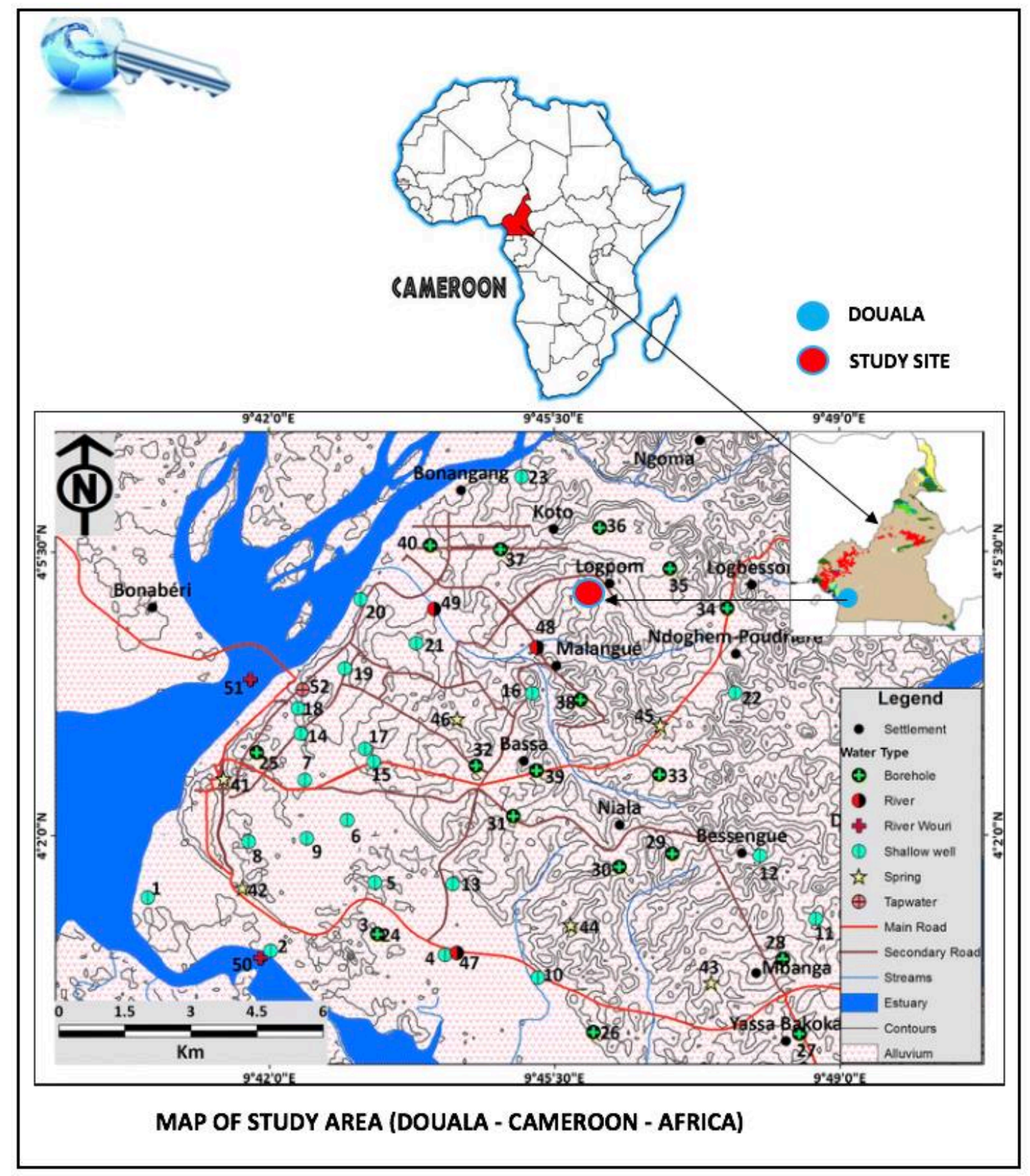

Figure 2: Location of water sources (well) in the study site (Douala Logpom). 


\section{Chapter 3}

\section{Characterizing the impacts of chloride ions on the efficiency of $\mathrm{Fe}^{\mathrm{0}}$}

\section{filters}

This chapter corresponds to the literature review and has been published as:

Tepong-Tsindé R., Phukan M., Nassi A., Noubactep C., Ruppert H. (2015): Validating the efficiency of the MB discoloration method for the characterization of $\mathrm{Fe}^{0} / \mathrm{H}_{2} \mathrm{O}$ systems using accelerated corrosion by chloride ions. Chemical Engineering Journal 279, 353-362. 


\subsection{Preamble}

This chapter evaluates the potential effects of salt intrusion (presence of $\mathrm{NaCl}$ ) on the efficiency of $\mathrm{Fe}^{0}$ filters. The evidence that chloride ions affect the extent of iron corrosion is given by the comparison of the chemical potential (Gibbs energy $-\mathrm{G}^{\circ} \mathrm{T}$ ) of iron corrosion by $\mathrm{H}_{2} \mathrm{O}$ (Equation 3.1) and $\mathrm{HCl}$ (Equation 3.2). Changes in Gibbs energy of substances are used to judge whether a chemical process can occur spontaneously under specific conditions of temperature and pressure (Groysman 2010).

Like for any other chemical process, corrosion occurs only if $\mathrm{G}_{\mathrm{T}}^{\circ}<0$.

$$
\begin{aligned}
& \mathrm{Fe}^{0}+2 \mathrm{H}_{2} \mathrm{O} \Rightarrow \mathrm{Fe}(\mathrm{OH})_{2}+\mathrm{H}_{2} \\
& \mathrm{Fe}^{0}+2 \mathrm{HCl} \Rightarrow \mathrm{FeCl}_{2}+\mathrm{H}_{2}
\end{aligned}
$$

The corresponding Gibbs energy changes at $\mathrm{T}=25{ }^{\circ} \mathrm{C}$ are -15.7 and $-84.9 \mathrm{~kJ} \mathrm{~mol}^{-1}$ respectively (Groysman 2010), showing that the presence of $\mathrm{Cl}^{-}$significantly accelerates iron corrosion. Another comparative lecture of Equations 3.1 and 3.2 is that $\mathrm{FeCl}_{2}$ is more stable than $\mathrm{Fe}(\mathrm{OH})_{2}$. In other words, in the presence of $\mathrm{NaCl}$, iron precipitation is delayed.

The current state-of-the-art knowledge on contaminant removal in $\mathrm{Fe}^{0} / \mathrm{H}_{2} \mathrm{O}$ systems is that it is the precipitation and further transformation of $\mathrm{Fe}(\mathrm{OH})_{2}$ which implies contaminant removal, mainly by adsorption and co-precipitation (Miyajima 2012, Miyajima and Noubactep 2012, Miyajima and Noubactep 2013, Miyajima and Noubactep 2015, Btatkeu-K et al. 2016, Gatcha-Bandjun et al. 2017). By complexing $\mathrm{Fe}^{2+}$, chloride ions avoid or delay the formation of contaminant scavengers. In this chapter, the impact of chloride ions on the efficiency of $\mathrm{Fe}^{0} / \mathrm{H}_{2} \mathrm{O}$ systems will be characterized using the methylene blue method (MB method) (Miyajima and Noubactep 2012, Btatkeu-K et al. 2016, Xiao et al. 2020b).

\subsection{The dynamic of the $\mathrm{Fe}^{0} / \mathrm{H}_{2} \mathrm{O}$ system and the $\mathrm{MB}$ method}

When a reactive piece of $\mathrm{Fe}^{0}$ is immersed in water, its spontaneous oxidative dissolution occurs after Equation 3.3. Generated $\mathrm{Fe}^{2+}$ ions may form complexes with available ligands, including $\mathrm{HO}^{-}$from water dissociation (Equation 3.4) and chloride from $\mathrm{NaCl}$ addition (Equation 3.5). Deriving from the solvent (water). $\mathrm{HO}^{-}$is stoichiometrically very abundant, meaning that whatever the chloride concentration, there shall be $\mathrm{Fe}(\mathrm{OH})_{2}$ precipitation if enough $\mathrm{Fe}^{0}$ is available. 


$$
\begin{aligned}
& \mathrm{Fe}^{0}+2 \mathrm{H}^{+} \Rightarrow \mathrm{Fe}^{2+}+\mathrm{H}_{2} \\
& \mathrm{Fe}^{2+}+2 \mathrm{OH}^{-} \Rightarrow \mathrm{Fe}(\mathrm{OH})_{2} \\
& \mathrm{Fe}^{2+}+2 \mathrm{Cl}^{-} \Rightarrow \mathrm{FeCl}_{2}
\end{aligned}
$$

The profound investigation of the $\mathrm{Fe}^{0} / \mathrm{H}_{2} \mathrm{O}$ system is complicated by the difficulty to perform Fe mass balance. Equation 3.3 implies that there are three ways to quantify the extent iron corrosion: (i) quantifying $\mathrm{Fe}^{0}$ depletion (e.g. mass loss), (ii) quantifying $\mathrm{H}_{2}$ evolution and (iii) quantifying soluble $\mathrm{Fe}^{2+}$ (Groysman 2010). At $\mathrm{pH}>4.5$ where iron precipitation is quantitative, this task is a very challenging because of the very low solubility of iron (Reardon 1995, Lewis 2010) and the interactions of $\mathrm{H}_{2}$ with both, solid iron corrosion products and metallic iron (Reardon 1995, Reardon 2014). According to Lee et al. (2004), "no carbon balances between reactants and products have ever been successfully done for many chlorinated hydrocarbons, which indicates that reduction pathways of metal-mediated reactions are not fully understood yet". The situation is not better for other species, including inorganic ones. One thinking mistake in this endeavor has been that the fraction of reactants enmeshed in the matrix of FeCPs has been considered reductively transformed (Noubactep 2007, Noubactep 2008). The digestion of FeCPs is known to be challenging (Heron et al. 1994, Noubactep et al. 2006) but has not been considered in the discussion of mass balance within the $\mathrm{Fe}^{0}$ research community (Noubactep 2007, Noubactep 2008).

\subsubsection{The conventional approach to investigate the $\mathrm{Fe}^{0} / \mathrm{H}_{2} \mathrm{O}$ system}

The use of $\mathrm{Fe}^{0}$ in permeable reactive barriers (PRBs) has emerged in the 1990s (Gillham 2008, Guan et al. 2015, Chen et al. 2019, Li et al. 2021). Fe ${ }^{0}$ PRBs are currently established as an effective and sustainable approach for the remediation of polluted groundwater. Several technical documents for the design and use of $\mathrm{Fe}^{0}$ PRBs have been developed (ITRC 1999, Schirmer 2003, ITRC 2005, ITRC 2011, CRC CARE 2016). These documents are regarded as useful guidance for assessing the suitability of $\mathrm{Fe}^{0}$ materials, designing $\mathrm{Fe}^{0}$-based systems, as well as operating, monitoring, and decommissioning the same. Laboratory testing as described in CRC CARE (2016) will be presented herein. CRC CARE (2016) is one of the most recently developed documents and can be considered as the state-of-the-art knowledge. Laboratory testing typically includes batch and column experiments. Where possible, testing should be performed by laboratories with proven expertise on individual aspects (CRC CARE 2016). Column experiments are designed from results of batch studies and should typically use site groundwater. Polluted water is pumped through the column at a velocity similar to 
field conditions. Concentrations of contaminants of concern, major ions, the $\mathrm{pH}$ value, and changes of the hydraulic conductivity are usually monitored to assess the efficiency of the design, including mineral precipitation (McGuire et al. 2003). The time-dependent changes of these parameters are plotted as a function of distance along the column. This experiment is replicated for each contaminant to determine the rate constant and calculate the half-life. Estimated half-lives for common contaminants using $\mathrm{Fe}^{0}$ are tabulated (CRC CARE 2016). Even though such values are just indicative and should be confirmed using site-specific information, the usefulness of half-live values is questionable because the intrinsic reactivity of used $\mathrm{Fe}^{0}$ materials also matters (McGeough et al. 2007, Li et al. 2019, Lufingo et al. 2019). On the other side, given the huge number of species that are potential pollutants at many sites, it would be difficult to determine their half-lives even under standardized conditions (Kim et al. 2014, Li et al. 2016, Li et al. 2019). The methylene blue method was introduced to consider the limitations of the half-life approach (Xiao et al. 2020b).

\subsubsection{The MB method}

Methylene blue (MB) adsorption on several minerals has been largely tested and used in environmental research (Mitchell et al. 1955, Barker and Linge 1981, Avom et al. 1997, Attia et al. 2008, Kurth 2008, Frost et al. 2010, Abdel Muslim et al. 2014, Btatkeu-K et al. 2016). Its applications include the measurement of specific surface areas (Barker and Linge 1981) and the characterization of the material's porosity (Attia et al. 2008). In investigating $\mathrm{Fe}^{0} / \mathrm{H}_{2} \mathrm{O}$ systems, MB is mostly considered as a model contaminant (Kurth 2008, Frost et al. 2010, Abdel Muslim et al. 2014). However, considering the evidence, that MB is a cationic dye (Mitchell et al. 1955) and that the $\mathrm{Fe}^{0}$ surface is permanently shielded with a positively charged oxide scale, more attention should be paid to the real mechanism of MB discoloration in the presence of metallic iron. The historical work of Mitchell et al. (1955) has supported this reasoning.

In the neutral $\mathrm{pH}$ range, the surface of sand is negatively charged (Kosmulski 2016). This makes sand an excellent adsorbent for positively charged MB. When sand is coated with positively charged iron oxides, its affinity to MB automatically decreases. Mitchell et al. (1955) have excellently demonstrated this evidence using sixty-five (65) natural sand specimens. In fact, after freeing sand specimens from the inter-granular material (including iron oxides), their adsorption for MB considerably increased. In other words, if the same sand is coated with iron oxides (FeCPs) to several, then differential extents of MB discoloration will be achieved. The MB method is grounded on this premise (Miyajima 2012, Btatkeu-K et 
al. 2016). If the same $\mathrm{Fe}^{0}$ mass is admixed to various masses of sand for the same duration, sand will be deferentially coated with FeCPs. For a given experimental design ( $\mathrm{pH}$ value, shaking intensity, temperature, volume of solution), the relative mass of $\mathrm{Fe}^{0}$ and sand to be used are to be determined in primarily experiments.

The MB method consists in following the time-dependent extent of MB discoloration in various $\mathrm{Fe}^{0}$ :sand mixtures (including pure sand). Observed changes correspond to the extent of sand coating by in-situ generated FeCPs. Thus, without any iron mass balance nor any identification or quantification of the generated FeCPs, their impact is characterized. For this reason, $\mathrm{MB}$ is an operational tracer of the reactivity in $\mathrm{Fe}^{0} / \mathrm{H}_{2} \mathrm{O}$ system (Xiao et al. 2020b).

\subsubsection{Past achievements of the MB method}

Noubactep and his collaborators have introduced the MB method around 2012 (Miyajima 2012, Miyajima and Noubactep 2012). Its first merit was to consolidate past results that coprecipitation is a stand-alone path in the process of contaminant removal in $\mathrm{Fe}^{0} / \mathrm{H}_{2} \mathrm{O}$ systems (Noubactep et al. 2005, 2006). In fact, because of electrostatic non-favorable conditions, MB adsorption by FeCPs is negligible. Thus, MB discoloration is due to its enmeshment in precipitating nascent FeCPs. Btatkeu-K et al. (2013, 2014a, 2014b) and explains that FeCPs for MB discoloration represent the excess after sand coating. Sand coating also competes with $\mathrm{MB}$ discoloration as both $\mathrm{Fe}^{2+}$ and $\mathrm{Fe}^{3+}$ are positively charged (like $\mathrm{MB}$ ). However, $\mathrm{MB}$ adsorption onto sand is suppressed only after coating with FeCPs (Btatkeu-K et al. 2016). As a result, the MB method implicitly demonstrates the ion selective nature of the $\mathrm{Fe}^{0} / \mathrm{H}_{2} \mathrm{O}$ system (Sato 2001). Phukan (2015) has confirmed this selectivity in parallel experiments using MB and Orange II (Phukan et al. 2015, 2016).

The most important achievement of the MB method is that is has ended the discussion as whether admixing $\mathrm{Fe}^{0}$ to sand (and other aggregates) is beneficial to $\mathrm{Fe}^{0}$ filtration systems or not. $\mathrm{Fe}^{0} /$ sand mixtures were considered useful as $\mathrm{O}_{2}$ scavengers designed to enable that pure $\mathrm{Fe}^{0}$ systems operate under anoxic conditions (Westerhoff and James 2003). Admixing sand to $\mathrm{Fe}^{0}$ was considered as " $\mathrm{Fe}^{0}$ dilution" with the potential to negatively impact the efficiency of the systems. The MB method has clearly demonstrated that, due to the volumetric expansive nature of iron corrosion, admixing non-expensive aggregates with $\mathrm{Fe}^{0}$ is even a prerequisite for sustainability (Btatkeu-K et al., 2014a, 2014b, 2016), validating the concept of Domga et al. (2015). 


\subsection{The impact of chloride on the $\mathrm{Fe}^{0} / \mathrm{H}_{2} \mathrm{O}$ system}

One objective of the research has been to design a long-lasting drinking water filter for coastal regions with fluctuating salt intrusion into the aquifer.

The effect of the chloride ions $\left(\mathrm{Cl}^{-}\right)$on the efficiency of $\mathrm{Fe}^{0} /$ sand systems was characterized in column studies for 4 months on basis of methylene blue (MB) discoloration. Tested systems were: pure sand $\left(0 \% \mathrm{Fe}^{0}\right)$ as reference and a $\mathrm{Fe}^{0} /$ sand mixture $\left(50\right.$ vol.\% $\mathrm{Fe}^{0}$ and 50 vol.\% sand). Tested $\mathrm{Cl}^{-}$concentrations were 0.0, 2.1, 21.1 and $42.2 \mathrm{mM}$. The used $\mathrm{MB}$ concentration was $16 \mu \mathrm{M}\left(5 \mathrm{mg} \mathrm{L}^{-1}\right)$ and used $\mathrm{Fe}^{0}$ mass was $100 \mathrm{~g}$. Discoloration experiments lasted for 89 days and were followed by a 26 days desorption experiment. Each system was characterized by the time-dependent changes of the $\mathrm{pH}$ value, the iron breakthrough, the MB breakthrough, and the hydraulic conductivity (permeability). During the discoloration experiments, a total of 17.4 L (184 pore volumes) of the MB solution flowed through each column (279 $\mu \mathrm{M}$ dye or $87.2 \mathrm{mg}$ ). No significance changes in $\mathrm{pH}$ value and permeability were observed. Discoloration and desorption results confirmed that sand is an excellent $\mathrm{MB}$ adsorbent (only $11 \%$ discoloration in the reference system). In the absence of $\mathrm{Cl}^{-}, 15 \mathrm{mg} \mathrm{MB}$ was discolored. Up to $18 \mathrm{mg}$ of $\mathrm{MB}$ was discolored in the presence of $\mathrm{Cl}^{-}$. A similar trend was observed for the iron release which was $7.3 \mathrm{mg}$ at $0.0 \mathrm{mM} \mathrm{Cl}^{-}$and $16.2 \mathrm{mg}$ at $42.2 \mathrm{mM} \mathrm{Cl}^{-}$. This confirms that chloride ions enhance the kinetics of $\mathrm{Fe}^{0}$ corrosion and thus the production of contaminant collectors (for MB co-precipitation). Results confirmed the suitability of MB as a powerful operative indicator for the characterization of processes in the $\mathrm{Fe}^{0} / \mathrm{H}_{2} \mathrm{O}$ system. 


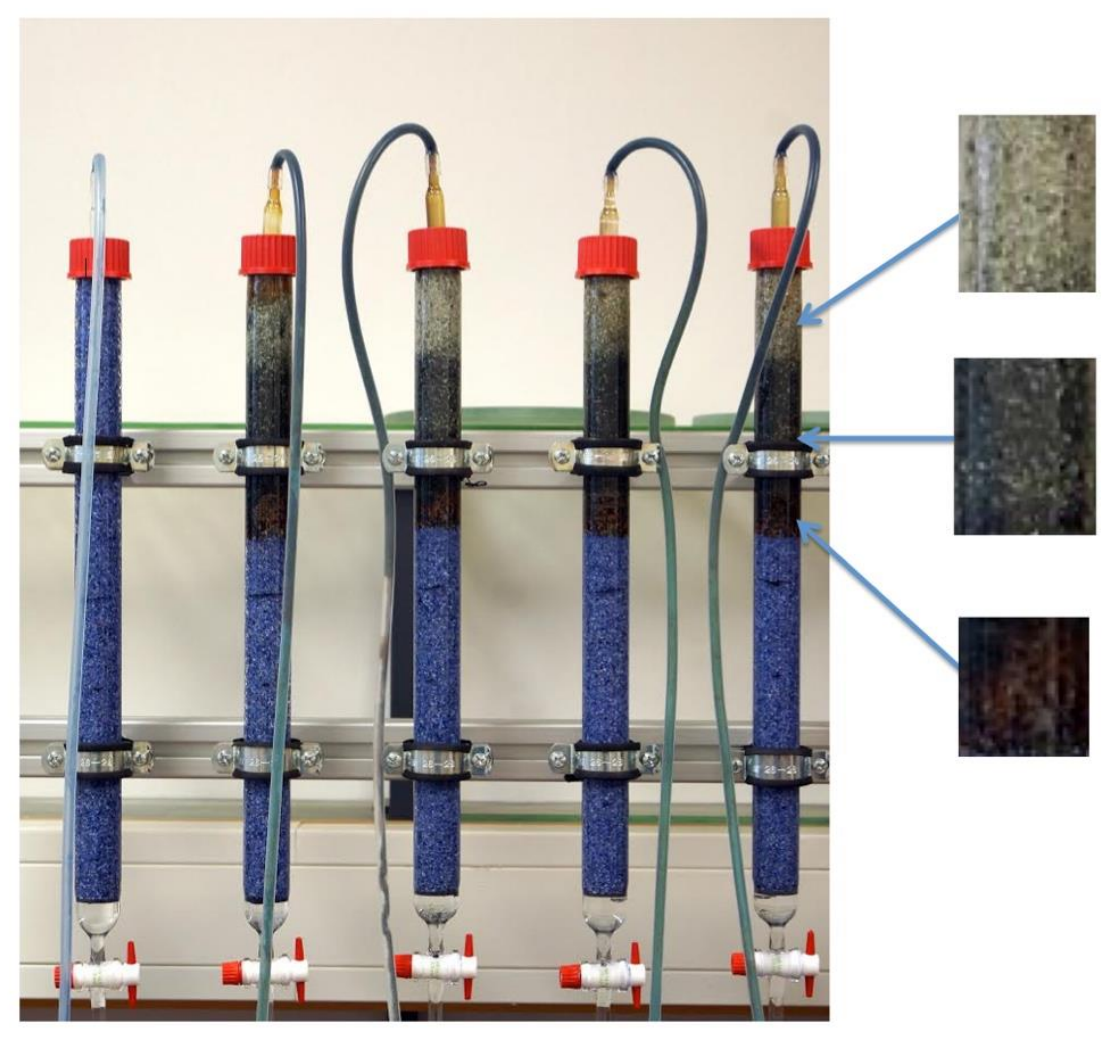

Figure 3: Photograph of a column design depicting the typical sequence of coloration described by Westerhoff and James (2003). The picture shows that the entrance zone of the $\mathrm{Fe}^{\mathrm{0}}$ /sand zone is colored brown while the upper section is black. The sand layer after the $\mathrm{Fe}^{0}$ /sand zone more or less maintains its "white" / brownish color by $\mathrm{Fe}^{\mathrm{III}}$ iron oxide from the $\mathrm{Fe}^{0}$ /sand zone. Sand in the reference system (first column) and the sand layers preceding the $\mathrm{Fe}^{0}$ /sand zone are blue colored by methylene blue. (Picture from Miyajima 2012)

Five glass columns were used for the design. Four columns filled with sand and granular iron (sandwiched with sand in the column) and one reference column (sand alone). It is seen that the reference system (sand alone) and the sand layer preceding the reactive layer are uniformly blue-colored. A brownish coloration of the tubing material is also observed in all $\mathrm{Fe}^{0}$-based systems (Figure 3 ).

These experiments have clearly demonstrated that seawater intrusion would enhance the concentration of dissolved iron in the effluent of any $\mathrm{Fe}^{0}$-based filter that is initially designed for low saline or fresh water. For this reason, in case of a saltwater intrusion, new $\mathrm{Fe}^{0}$ filters should be designed which incorporate for example a subsequent unit containing biochar for iron removal (Gwenzi et al. 2017). However, elevated concentration of dissolved iron is not the sole potential problem, because effluent iron concentration increases due to the higher solubility of $\mathrm{FeCl}_{2}$ and $\mathrm{FeCl}_{3}$ relative to $\mathrm{Fe}(\mathrm{OH})_{2}$ and $\mathrm{Fe}(\mathrm{OH})_{3}$ (Gatcha-Bandjun et al. 2017). The hydroxides are the real contaminant scavengers, meaning that thicker $\mathrm{Fe}^{0}$-based beds 
would be necessary to achieve the expected efficiency. $\mathrm{Fe}^{0}$ systems have been reported to induce water desalination (Antia 2015a, 2015b, 2016, 2917), but this aspect is not presented herein. It is certain that water desalination is complex and expensive. It is better to avoid it, for example by increasing artificial groundwater recharge to balance extracted groundwater (Marwa et al. 2018, Qi et al. 2019, Pembe-Ali et al. 2020). 


\section{Chapter 4}

\section{Designing and pilot-testing a household $\mathrm{Fe}^{0} \mathrm{SW}$ filter in Douala (Canmeroon)}

This chapter has been published as:

Tepong-Tsindé R., Ndé-Tchoupé A.I., Noubactep C., Nassi A., Ruppert H. (2019): Characterizing a newly designed steel-wool-based household filter for safe drinking water provision: Hydraulic conductivity and efficiency for pathogen removal. Processes 7, 966. DOI: 10.3390/pr7120966 


\subsection{Introduction}

Lack of safe drinking water is one of the most characteristics and most serious health issues in the developing world (Ali 2014). All the 46 nations of Sub-Sahara Africa for example, currently have not achieved universal access to safe drinking water and most of them are not on track to meet the UN SDGs in 2030 (Hering et al. 2016, Nanseu-Njiki et al. 2019). This sad situation calls for the development of applicable and affordable tools to treat available water sources on a decentralized manner (Shannon et al. 2008). In the city of Douala, well water is by far the main source of drinking water (Ako et al. 2010), but its quality is largely unknown (Mafany et al. 2006). During the past two decades, intensive efforts have been made to establish metallic iron $\left(\mathrm{Fe}^{0}\right)$ based filtration systems as a universal tool for potable water production (Ngai et al. 2006, Hussam and Munir 2007, Banerji and Chaudhari 2017, NanseuNjiki et al. 2019, Yang et al. 2020).

Although $\mathrm{Fe}^{0}$-based filters are the most extensively investigated approach in the last two decades, scientifically sound, economically viable, and sustainable strategies for their design remain elusive (Etmannski 2014, Banerji and Chaudhari 2017, Bretzler 2018, Bretzler et al. 2020, Ullah et al. 2020, Yang et al. 2020). To date, the design of sustainable $\mathrm{Fe}^{0}$ filters is impaired by the evidence that the kinetics of iron corrosion under environmental conditions is rather slow and could continue for several years or even decades (Wilkin et al. 2014). While the kinetics of $\mathrm{Fe}^{0}$ specimens typically used in water treatment is yet to be characterized, the greatest challenge will be to couple "residual corrosion" and contaminant removal. Given that each $\mathrm{Fe}^{0}$ specimen and each water source are unique, it is rather difficult to generate transferable results. There have been little efforts in this sense as for example the seven or eight classes of iron steel wool $\left(\mathrm{Fe}^{0} \mathrm{SW}\right)$ have been mistakenly presented as $\mathrm{Fe}^{0} \mathrm{SW}$, without even specifying the used grade (Lufingo et al. 2019). Additionally, the tested experimental duration has rarely accounted for the non-linear kinetics of $\mathrm{Fe}^{0}$ corrosion (Cao et al. 2020, Xiao et al. 2020a, Xiao et al. 2020b, Yang et al. 2020).

Any sustainable $\mathrm{Fe}^{0}$-based solution for decentralized safe drinking water provision should be presented with an appropriate business model. Such a model includes the price of the used $\mathrm{Fe}^{0}$ specimen, the admixing material (e.g. sand), and the filter container. The business model also includes the service life of filters and how they will be decommissioned (Etmannski 2014). In the absence of reliable and accurate knowledge on the long-term reactivity of used $\mathrm{Fe}^{0}$ serious business models are possible. The present work aims at contributing to fill this knowledge gap using $\mathrm{Fe}^{0} \mathrm{SW}$ as reactive material. 
The used $\mathrm{Fe}^{0} \mathrm{SW}(\mathrm{d}=50 \mu \mathrm{m})$ corresponds to grade 0 which is twice larger in diameter than the one used by Bradley et al. (2011) in their experiments lasting for 10 months. $\mathrm{Fe}^{0} \mathrm{SW}(\mathrm{d}=$ $25 \mu \mathrm{m}$ ) represented $10 \%$ of the reactive mixture and was depleted after eight months. Herein, preliminary experiments were performed with $50 \%$ (vol/vol) $\mathrm{Fe}^{0} \mathrm{SW}$ and the filters were clogged after six months. The main experiments were performed with $10 \%$ (vol/vol) $\mathrm{Fe}^{0} \mathrm{SW}$ and lasted for one year. No material depletion was observed. The results are presented and discussed in this chapter.

\subsection{Materials and Methods}

The choice to experiment with this filter $\left(\mathrm{BSF}+\mathrm{Fe}^{0}\right.$-Filter) was based on the following three criteria:

First, the $\mathrm{Fe}^{0}-\mathrm{SW}$ is an excellent choice as a source of $\mathrm{Fe}^{0}$ for the design of $\mathrm{Fe}^{0}$ - filters. The second hypothesis is that to properly size a $\mathrm{Fe}^{0}$ bed filter, that will be efficient and durable, amounts to defining well the mixture of materials forming the heart of such a system (reactive zone - RZ). The last hypothesis is that to reiterate while also demonstrating that the $\mathrm{Fe}^{0}$ bed filters are efficient and reliable systems, amounts to putting in advance its capacity, to chemically eliminate a pollutant that is difficult to extract in the like fluorine, and from a biological point of view, to eliminate pathogens.

Furthermore, the choice of $\mathrm{SW}$ as $\mathrm{Fe}^{0}$ (materials for the construction of the RZ) for this study is due to the fact that the EDTA tests suggest that the SW are more reactive than most local materials (Ndé-Tchoupé 2019, Hildebrant et al. 2020). 


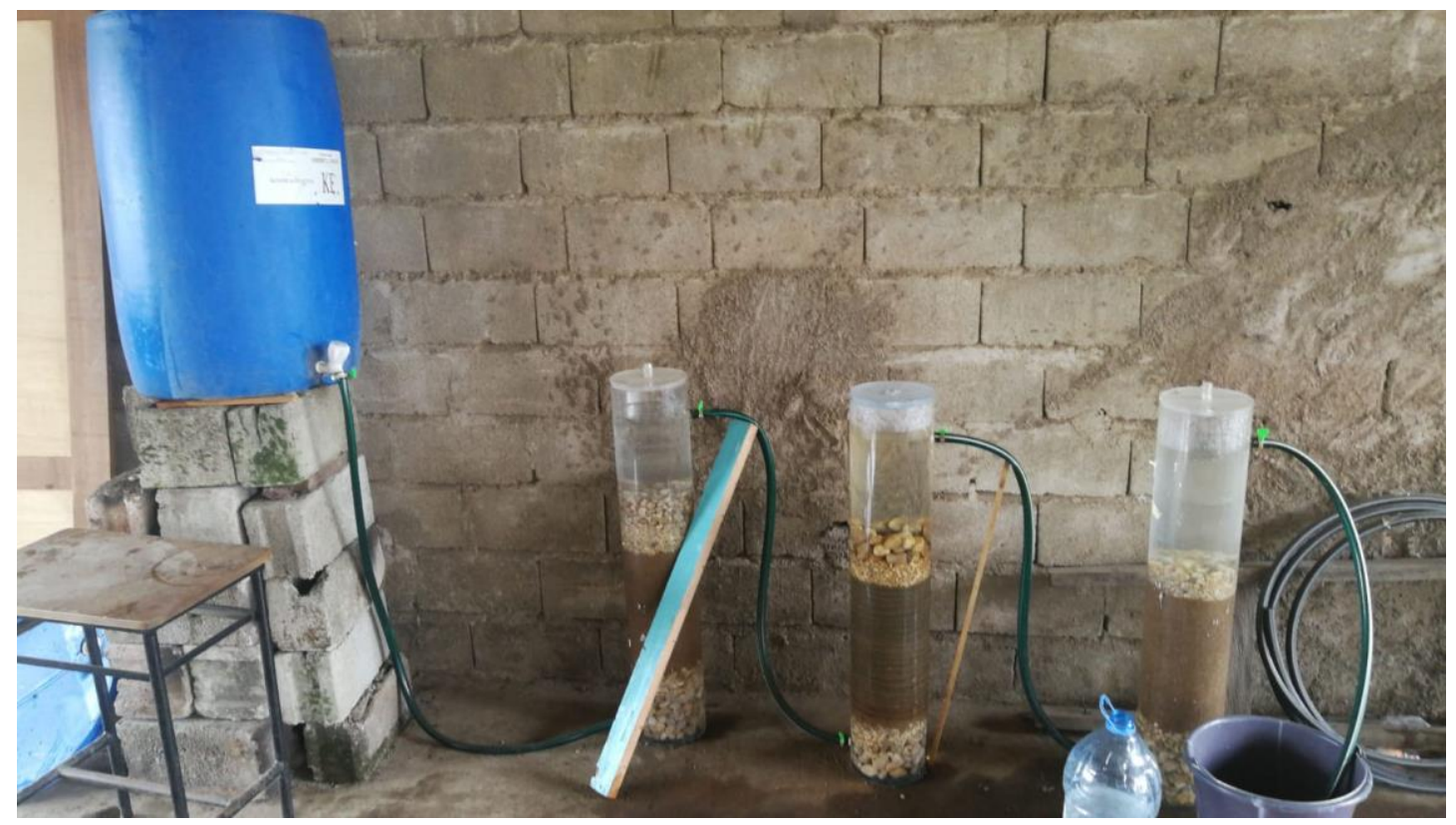

(A)

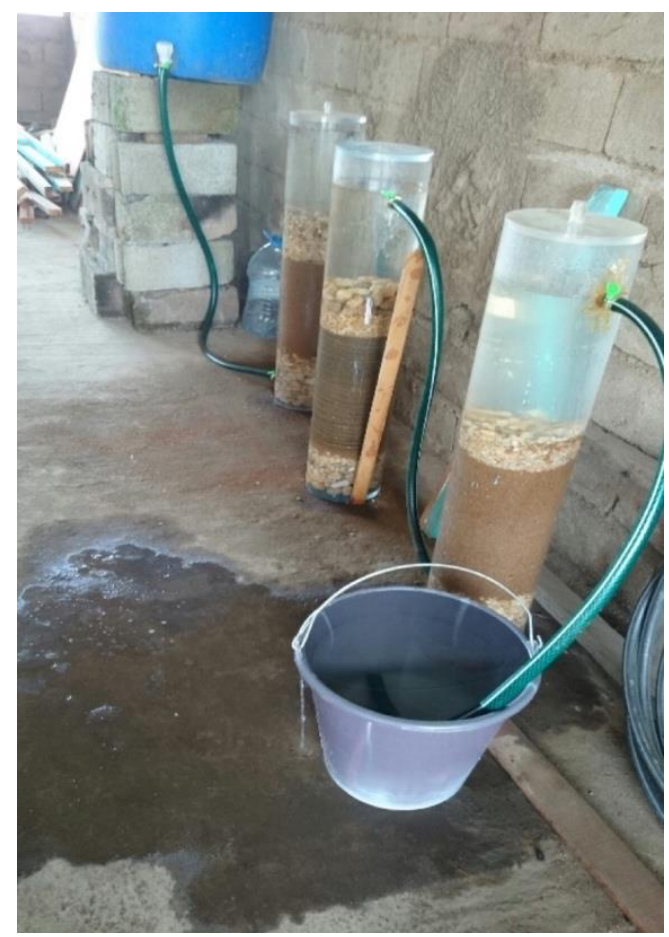

(B)

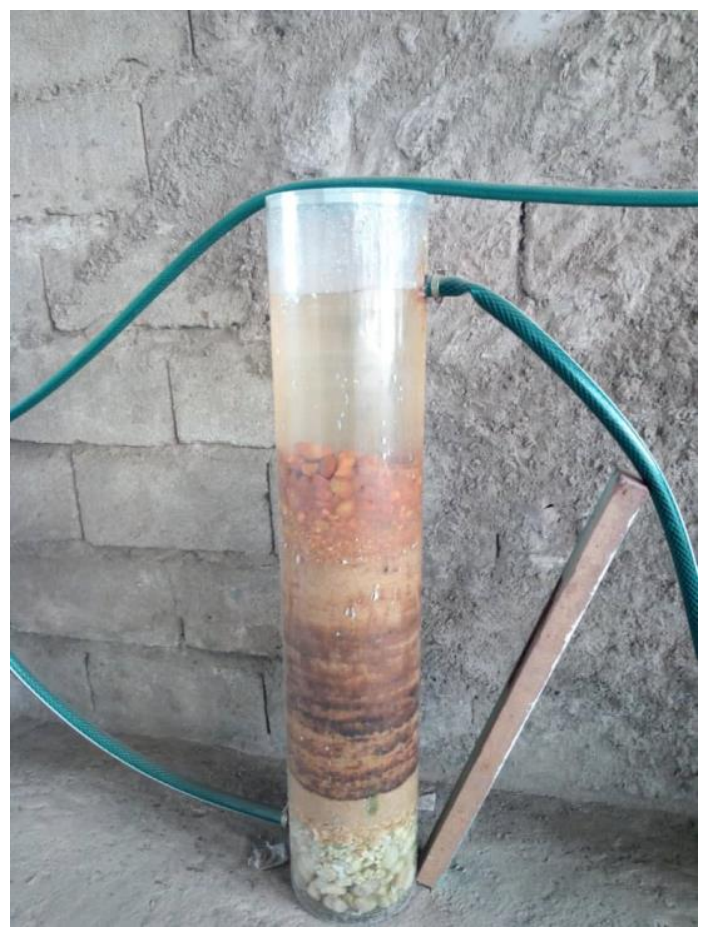

Figure 4: Picture of the designed filtration system: Well water was stored in blue $200 \mathrm{~L}$ tank. The first and the third columns are conventional bio sand filters (BSF). In the middle of column 2 is $\mathrm{Fe}^{0} \mathrm{SW}$ mixed with sand coarse (Picture B). The columns are connected to each other with a PET tube.

\subsection{Filter construction and Design}

The tested design is made up of three identical cylindrical Plexiglass columns with a length: of $100 \mathrm{~cm}$ and an inner diameter of $20.0 \mathrm{~cm}$ mounted in series: two conventional BSFs and 
one $\mathrm{Fe}^{0} \mathrm{SW}$ unit in between. Upon successful testing, the unit was intended to be transferred for use in households, but with a proper housing (e.g. concrete material). The test device was constructed inside a room of the Institute of Applied Technology in Douala. The used room was not a conventional experimental laboratory but offers representative conditions for a household situation. The room temperature range was $26 \pm 2{ }^{\circ} \mathrm{C}$.

Schematic diagram of the designed filtration system is presented in Fig. 4. The columns were connected to each other by using a $1.5 \mathrm{~m}$ PET (polyethylene terephthalate) tube with an inner diameter of $2.4 \mathrm{~cm}$. The columns were packed from the bottom to the top as follows (Table 2): $15.0 \mathrm{~cm}$ gravel $\left(\mathrm{H}_{\text {gravel, } 1}\right)$ followed by $40.0 \mathrm{~cm}$ of a reactive layer, and topped by a $15.0 \mathrm{~cm}$ gravel layer $\left(\mathrm{H}_{\text {gravel, }}\right)$. For column 1 and 3 , the reactive layer was a medium sand layer $\left(\mathrm{H}_{\text {sand, }}\right.$ 1). In column 2, the $40 \mathrm{~cm}$ consist of a mixture of $30.0 \mathrm{~cm} \mathrm{Fe}{ }^{0} \mathrm{SW}$ and coarse sand ( $\left.\mathrm{Fe}^{0} / \mathrm{sand}\right)$ (reactive zone RZ) sandwiched between two $5.0 \mathrm{~cm}$ medium sand layers $\left(\mathrm{H}_{\mathrm{sand}, 2}\right)$.

The reactive zone layer was prepared by carefully introducing sand grains and chopped $\mathrm{Fe}^{0}$ $\mathrm{SW}$ in small lofts into the column. The $\mathrm{Fe}^{0} /$ sand mixture $(10$ vol.\% $\mathrm{SW}+90$ vol.\% coarse sand) was previously mixed in a large beaker. Once in the column, water was added to the mixture and it was gently compacted by manual tapping using a $100 \mathrm{~mL}$ PET bottle filled with water. The $300 \mathrm{~g}$ of $\mathrm{Fe}^{0} \mathrm{SW}$ and $14,200 \mathrm{~g}$ of coarse sand mixed together, had a $\mathrm{Fe}^{0}$ concentration of 2.07 weight $\%$. The strong discrepancy between volume and weight percent is caused by the very low density of SW (low weight and large volume). To build a $20 \mathrm{~cm}$ reactive layer under their experimental conditions, Bradley et al. (2011) used $260 \mathrm{~g}$ of Fe $\mathrm{SW}^{0}$ (extra fine) with $1,563 \mathrm{~g}$ sieved sand (effective size $0.4 \mathrm{~mm}$ ). 


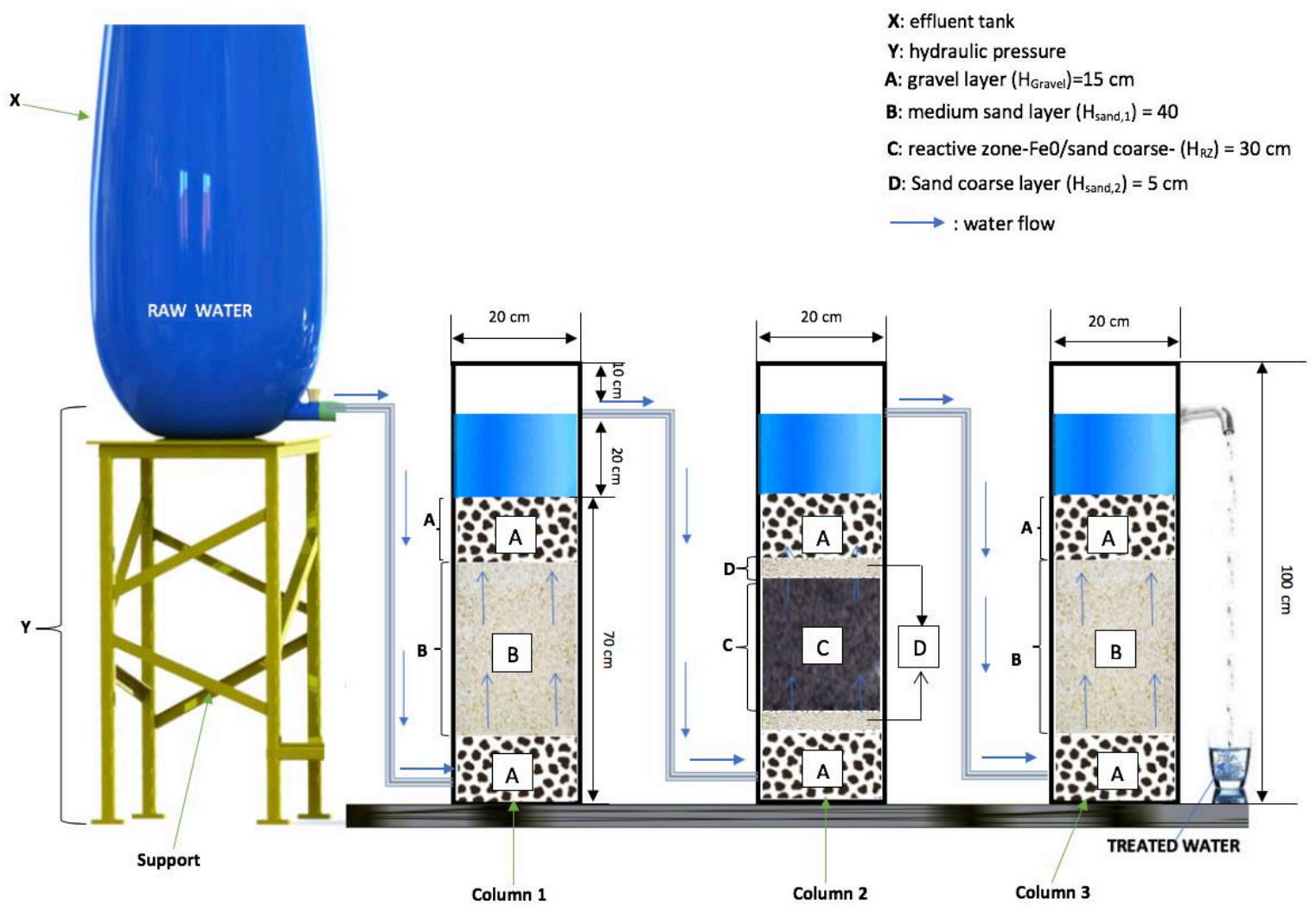

Figure 5: Schematic diagram of the designed filtration system: Well water was stored in $200 \mathrm{~L}$ tank. The first and the third columns are conventional bio sand filters (BSF). In the middle of column 2 is $\mathrm{Fe}^{0} \mathrm{SW}$ mixed with coarse sand. The columns are connected to each other with a PET tube.

Table 1: Summary of the used experimental set up. $\mathrm{H}_{\text {gravel1 }}$ and $\mathrm{H}_{\text {gravel2 }}$ are the heights of the underdrain and the upper layer respectively; $\mathrm{H}_{\text {sand1 }}$ the heights of medium sand; $\mathrm{H}_{\text {Sand1 }}$ is the medium sand layer (BSF) and $\mathrm{H}_{\mathrm{RZ}}$ is the height of the reactive layer $\left(\mathrm{Fe}^{0} /\right.$ sand) sandwiched by $\mathrm{H}_{\text {sand2. }}$.

\begin{tabular}{|l|c|c|c|}
\hline Designation & \multicolumn{3}{|c|}{ Height (cm) } \\
\hline & Column 1 & Column 2 & Column 3 \\
\hline Gravel ( $\left.\mathrm{H}_{\text {gravel 1 }}\right)$ & 15.0 & 15.0 & 15.0 \\
\hline Sand coarse (Hand2) & - & 5.0 & - \\
\hline medium sand (Hand1) & 40.0 & - & 40.0 \\
\hline $\mathrm{RZ}\left(\mathrm{Fe}^{0}\right.$ / Sand coarse) $\left(\mathrm{H}_{\mathrm{RZ}}\right)$ & - & 30.0 & - \\
\hline Sand coarse $\left(\mathrm{H}_{\text {Sand2 }}\right)$ & - & 5.0 & - \\
\hline Gravel $\left(\mathrm{H}_{\text {gravel } 2)}\right.$ & 15.0 & 15.0 & 15.0 \\
\hline
\end{tabular}


The total thickness of solid materials in each column was $70.0 \mathrm{~cm}$, the free water column was $15 \mathrm{~cm}$ thick.

\subsection{Solid materials}

\subsubsection{Metallic iron $\left(\mathrm{Fe}^{0}\right)$}

$\mathrm{Fe}^{0} \mathrm{SW}$ was used as a generator of iron hydroxides for contaminant scavenging (Noubactep et al. 2009, Jia et al. 2007, James et al. 1992). A fine-grade $\mathrm{Fe}^{0} \mathrm{SW}$ (grade 0) of $50 \mu \mathrm{m}$ fiber thickness from "Grand Menage" trademark brand purchased in Douala (Cameroon) was used. Its average elemental composition was not determined as it was proven to be not a stand-alone determining reactivity parameter for $\mathrm{Fe}^{0}$ in general. Recently, Lufingo et al. (2019) presented the first systematic study comparing the intrinsic reactivity of $\mathrm{Fe}^{0} \mathrm{SW}$. The elemental composition $(\%)$ of the grade $0(\mathrm{~d}=50 \mu \mathrm{m})$ material they tested was: Fe: $99.08 ; \mathrm{Co:} 0.05 ; \mathrm{Cu}$ : 0.27; Ni: 0.11; and Cr: 0.49 .

The $\mathrm{Fe}^{0} \mathrm{SW}$ used in this study was chopped in sections of 1.0 to $5.0 \mathrm{~mm}$ length.

\subsubsection{Sand}

The used sand was a natural material from the Mungo River (Cameroon). Mungo sand was selectively sieved, using a set of sieves to split the sand to gravel. The sieve A made with grain size of $2 \mathrm{~mm}$ in diameter (metal net) is used to select a more coarse sand. Sieve B made with mosquito net with grain size of $0.63 \mathrm{~mm}$ in diameter is used to obtain a medium sand. This medium sand is retained using a sieve with a size of $0.2 \mathrm{~mm}$ in diameter (Fig. 6).

The portion passing through $2 \mathrm{~mm}$ sieve and retained on $0.63 \mathrm{~mm}$ was mixed to $\mathrm{Fe}^{0}-\mathrm{SW}$ to build the reactive zone and to sandwich these RZ layer. The medium sand retained with the sieve with a size of $0.2 \mathrm{~mm}$ is used as filter media in the BSFs $\left(\mathrm{H}_{\text {sand1 }}\right)$. This step is also to eliminate all silt and clay contained in sand.

As received Mungo sand was washed several times using tap water until the wash water became clear. Retained fractions were separately warmed in boiling water for about $3.0 \mathrm{~h}$. The sand was further dried at the sun for about $6.0 \mathrm{~h}$. Sand was used because of its worldwide availability and its use as an admixing agent in $\mathrm{Fe}^{0} / \mathrm{H}_{2} \mathrm{O}$ systems (Ndé-Tchoupé 2019). 


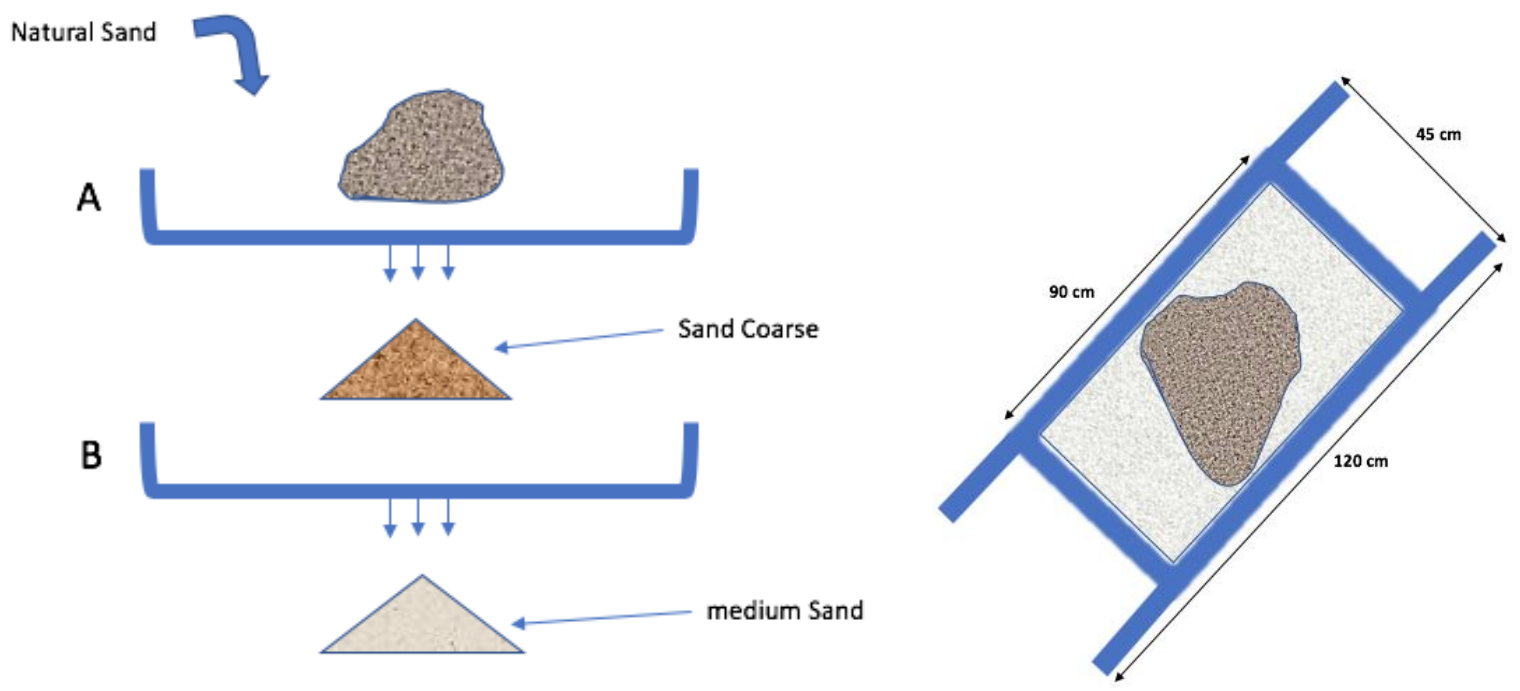

Figure 6: This step needed to sieve the grad of medium sand media. Sand coarse is maintained between $\mathrm{A}$ ( $2 \mathrm{~mm}$ in diameter) and $\mathrm{B}(0.63 \mathrm{~mm}$ in diameter). The sieve material for sieve $\mathrm{A}$ is a metal net and for the sieve B is the mosquito net. Each sieve is made with wooden frame.

\subsubsection{Gravel}

The Gravel was pre-treated like coarse sand. The particle size separated by two sieves ranged from (B') $4 \mathrm{~mm}$ to (A') $8 \mathrm{~mm}$ (Fig. 7). Gravel was used as lower supporting layer and as top layer in the individual columns. The bottom gravel layer partially removes solids from raw water entering the first column (Fig. 5). The gravel layer also prevents the entrance of sand particles into the inlet pipe and facilitates the water flow in the inlet of the column. Wegelin (1996) also recommended a gravel layer with grain sizes between 4 to $8 \mathrm{~mm}$.
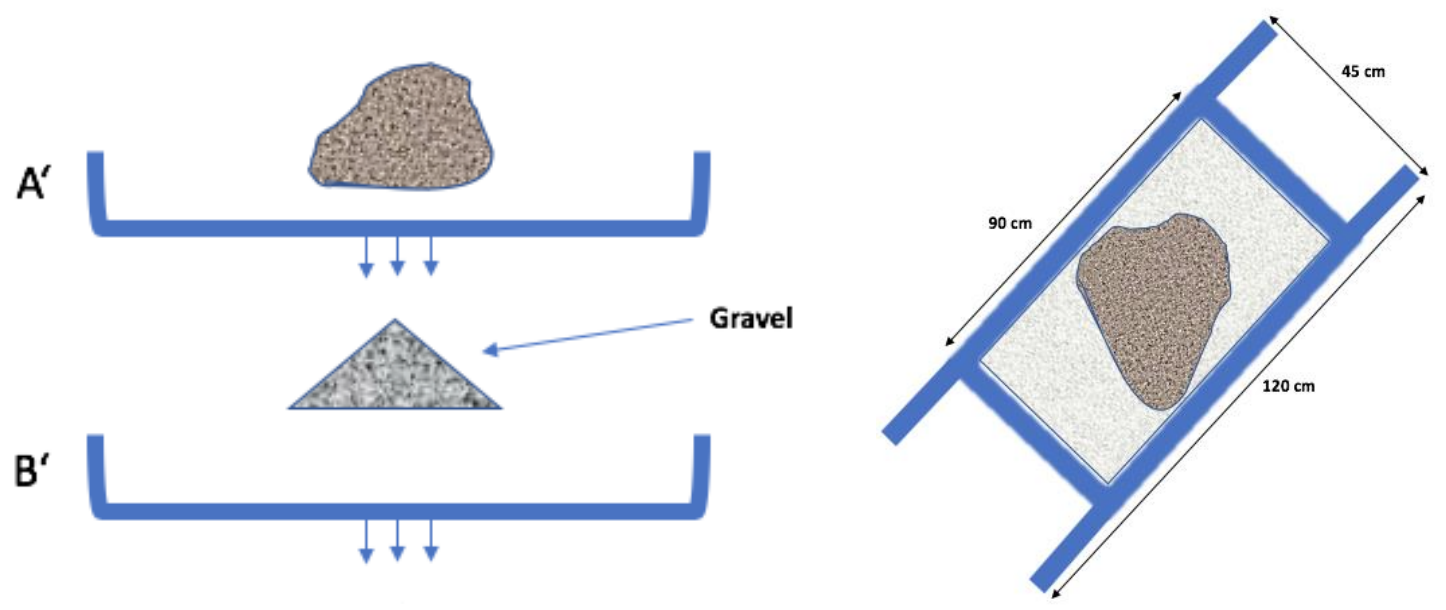

Figure 7: Scheme of the steps to obtain gravel with 4 to $8 \mathrm{~mm}$ diameter. A' is the first step of sieve to obtain gravel but the step B' is to eliminate all sand size contain in gravel from A'. The sieve materials in sieves A' and B' consist of metal wire meshes fixed in a wooden frame. 


\subsection{Construction protocol and guideline for the $\mathrm{Fe}^{0}$ based sand filter device}

This protocol describes the steps in preparing solid media (medium sand, coarse sand, gravel and $\mathrm{Fe}^{0}-\mathrm{SW}$ ) for use in a $\mathrm{Fe}^{0}$ based filter device.

\section{(1) Prepare the sand and gravel for their use in the filter device}

First, mixed sand and gravel must be separated into its different-sized grain sizes by passing through a series of sieves, because the filtration rate is strongly influenced by the grain size of media. Next, sand and gravel must be washed to remove finer particles such as silt, clay, and other impurities.

An important factor is the selecting of source of sand and gravel. Last, use natural water to wash the sand and gravel, and place the media in the sun to dry: the solar radiation will inactivate any possible attached pathogens. If this is not possible, remember that pathogens within the water or attached to sand grains will be consumed by the filter's normal biological processes or, when exposed to an anaerobic environment within the filter, will not survive.

\section{(2) The following items are necessary:}

one 200 liters (50 gallons) raw water tank, one 50 liters (12,5 gallons) drinking water tank,

Column integrated Tubes (diameter of $2 \mathrm{~cm}$, length $=3 \mathrm{~cm}$ ) to connect the columns, PVC pipe (inner diameter of $2 \mathrm{~cm}$, length $=150 \mathrm{~cm}$ ) and ring to attach $\mathrm{PVC}$ pipe and Column integrated Tubes.

One tap for flow rate regularization.

One $100 \mathrm{~mL}$ PET bottle filled with water to compact media in the column by manual tapping. Materials for testing filter flow rate including a measuring vessel (1-liter PET bottle is adequate) and one stopwatch.

(3) To place the media in the filter columns, certain procedures must be respected.

At first, place the empty filter units inside the house or in a corner of a yard. It must be an appropriate place because its location final. Secondly fill the column with media from the bottom to the top as follows: a) Gravel, sand, and gravel for the BSF filter column and b) Gravel, coarse sand, $\mathrm{Fe}^{0} \mathrm{SW} /$ coarse sand mixture ( $\mathrm{Fe}^{0} /$ sand), coarse sand, and gravel for the $\mathrm{Fe}^{0} \mathrm{SW}$ based filter column. After filling, make sure that the drain hole, PVC connect pipe, and outlet pipe are unobstructed.

Following steps are necessary for mounting the filter:

a) Installing the raw water tank by the height greater than that of the columns (to generate a gravity pressure) 
b) Place all the columns in order at the same horizontal level as follows: $\mathrm{BSF} 1, \mathrm{Fe}^{0} / \mathrm{Sand}$ Filter, BSF2.

c) Connect the raw tank and the columns with PVC connecting pipes as follows: outlet of raw tank and inlet of the first column. Then outlet of the BSF1 column to inlet of $\mathrm{Fe}^{0} / \mathrm{Sand}$ Filter column. At the end connect the outlet of this to the inlet of BSF2.

Ensure that the connecting pipes are securely attached to each column and to the raw water tank.

Water is required to be inside the filter before starting the filtration of the raw water. This prevents pockets of air from being trapped within the media. The presence of air pockets would slow down the flow rate. A reliable filling of media in the column is essential for a proper operation of the filter.

Fill natural raw water in 200 liters (50 gallons) and let it flow until all columns filling with water. After that, the level of water in all column is stable, let it flow through out of the outlet pipe of the last column for around 21 days. So that the filter should reach the maturation.

The circulation and pressure of the water in the filter is determined by the hydraulic pressure. Due to a siphoning effect, the water will stop coming out of the filter when the water is at the same level as the bottom of the column integrated tubes.

\subsubsection{Testing filter flow rate}

The amount of water that flows through the filter is controlled by the column diameter, the thickness and grain size distribution of sand media contained within the filter and the control tap place by outlet of the influent tank. If the rate is too fast, the efficiency of bacterial removal may be reduced by lowering the flow at the tap. If the flow rate is too slow, the amount of treated water is insufficient to meet the needs of the users and the flow should be increased at the tap.

The flow rates of a filter can be derived from the time it takes to fill up a container of a known volume with water. To test the flow rate, place a graduated 1-liter container under the outlet of the filter. The flow rate through the filter decreases as the height of the water in the influent reservoir drops. Measure with a stopwatch how long it takes to completely fill the 1-liter container with filtered water. For this study 0.34 liter has been obtained per min (that means $176.5 \mathrm{sec}$ for one liter).

The filter is still functional, but it will require more maintenance than normally due to frequent clogging. Some experimentation will be necessary to achieve the desired flow rate. 
Since the flow rate is controlled at the tap and by the porosity of the sand, the tap should be adjusted and/or the sand should be washed more intensively (removal of finer particles) to achieve the desired flow rate.

\subsubsection{Preparation of the material}

Consumers are required to disinfect the gravel and coarse and medium-sized sand by boiling it in water for approx. 3 hours, before drying it in the sun for about 6 hours. Afterwards, the SW chopped in small particles was mixed with coarse sand to obtain the reaction layer of the second column.

\subsection{Experimental procedure}

An intermittent gravity-driven filtration was performed for one year with the device described above (Fig. 4). Each filtration event was initiated by opening the outlet-controlled tap connected to column 1 and allowing the stored well water from the reservoir to flow through the entire system. Experiments were conducted on a daily basis from Monday to Friday. Two hundred liters of water were filtered per filtration event. Raw water was collected from a well, used for drinking and other domestic purposes (Tab. 2). Since the well water was polluted with microorganisms; there was no need for artificially seeding it. The volume of effluent recorded during the first $10 \mathrm{~min}$ was used to calculate the flow velocity. At the end of the filtration event, the reservoir was immediately refilled with $200 \mathrm{~L}$ well water. The initial flow rate was $0.34 \mathrm{~L} \mathrm{~min}^{-1}\left(20.40 \mathrm{~L} \mathrm{~h}^{-1}\right)$ and was not further modified. This approach perfectly mimics pilot-scale intermittent filtration using household filters for daily water need in lowincome communities. The $\mathrm{pH}$ value, the iron level, and the extent of water decontamination were monitored. Complete water analysis including search for pathogens was performed twice per month at the Centre Pasteur in Douala.

\subsection{Sample collection and efficiency characterization}

The $1 \mathrm{~L}$ sample bottles were provided by the Laboratory at the Centre Pasteur du Cameroon (Douala) and used to collect water samples from the filter unit twice per month for microbial analysis. These samples included the raw water from a private well (Tab. 2). The time from sample collection and transportation to the lab was less than 4 hours. It is considered that the effects of time and temperature on microbial survival is negligible. 
Table 2: Average composition of the used well water. The well is polluted with coliforms and depicts high levels of conductivity and turbidity compared to the WHO guidelines (2017). WHO stands for World Health Organization.

\begin{tabular}{|l|l|l|l|}
\hline Parameter & Unit & Well Water & WHO (guideline) \\
\hline Turbidity & $(\mathrm{NTU})$ & $35 \pm 2$ & $<5$ \\
\hline Conductivity & $\left(\mu \mathrm{S.cm}{ }^{-1}\right)$ & $296 \pm 7$ & 250 \\
\hline Total iron & $\left(\mathrm{mg} \mathrm{L}^{-1}\right)$ & $1.45 \pm 0.25$ & $<0.2$ \\
\hline Nitrate & $\left(\mathrm{mg} \mathrm{L}^{-1}\right)$ & $23.5 \pm 4.5$ & $<50$ \\
\hline pH value $\left(25^{\circ} \mathrm{C}\right)$ & $(-)$ & $4.9 \pm 0.2$ & $6.5-8.5$ \\
\hline Total coliform $(\mathrm{TC})$ & $\left(\mathrm{UFC} \mathrm{\textrm {mL } ^ { - 1 } )}\right.$ & $1949 \pm 45$ & 0.0 \\
\hline Faecal coliforms $(\mathrm{FC})$ & $\left(\mathrm{UFC} \mathrm{mL}^{-1}\right)$ & $1495 \pm 97$ & 0.0 \\
\hline
\end{tabular}

The efficacy of the designed filter to treat water was accessed by the extent of reducing the concentration of fecal coliform (FC) and total coliform (TC). In addition, turbidity, permeability loss, nitrate, and iron concentration were monitored.

\subsection{Analytical methods}

Iron concentrations were determined by using a UV-Vis spectrophotometer (Dr. Lange CADAS 200 LPG 392). The working wavelength was $510 \mathrm{~nm}$. A cuvette with $1.0 \mathrm{~cm}$ light path was used. The iron determination followed the o-phenanthroline method (Saywell and Gunningham 1937, Fortune and Mellon 1937). The spectrophotometer was calibrated for iron concentrations $\leq 10.0 \mathrm{mg} \mathrm{L}^{-1}$. The $\mathrm{pH}$ values were measured by a WTW $\mathrm{pH}$ meter. Conductivity was analyzed by the ISO 7888 method using a portable (WTW 340i) conductivity meter with automatic temperature compensation, so that all results refer to 20 ${ }^{\circ} \mathrm{C}$. All other parameters including turbidity and biological analysis were performed at the laboratory of the Institute Louis Pasteur in Douala using following analytical method (Tab.3): 
Table 3: Analytical method used in this study for physico-chemical and biological parameters

\begin{tabular}{|c|c|c|c|c|c|}
\hline $\begin{array}{c}\text { Physico-chemical } \\
\text { parameters }\end{array}$ & Abbreviation & Unit & Analytical method & Water fraction & $\begin{array}{c}\text { Location of } \\
\text { analysis }\end{array}$ \\
\hline Turbidity & Turb & NTU* & $\begin{array}{c}\text { NF EN ISO 7027: } \\
\text { nephelometry }\end{array}$ & Whole water & in situ \\
\hline Conductivity & $\overline{\mathrm{EC}}$ & $\mu \mathrm{S} \mathrm{cm}^{-1}$ & ISO 7888 & Whole water & in situ \\
\hline Total Iron & $\mathrm{Fe}$ & $\mathrm{mg} \mathrm{L}^{-1}$ & $\begin{array}{c}\text { Validated in-house method: } \\
\text { o-phenanthroline }\end{array}$ & \begin{tabular}{|c|}
$\begin{array}{c}\text { Dissolved fraction } \\
\text { (filtered at } 0.45 \\
\mu \mathrm{m})\end{array}$ \\
\end{tabular} & Laboratory \\
\hline Nitrates & NO3 & $\mathrm{mg} \mathrm{L}^{-1}$ & $\begin{array}{l}\text { Validated in-house method: } \\
\text { capillary electrophoresis }\end{array}$ & \begin{tabular}{|c|}
$\begin{array}{c}\text { Dissolved fraction } \\
\text { (filtered at } 0.45 \\
\mu \mathrm{m})\end{array}$ \\
\end{tabular} & Laboratory \\
\hline Power of hydrogen & $\mathrm{pH}\left(25^{\circ} / 77^{\circ} \mathrm{F}\right)$ & $(-)$ & NF T90-008 & Whole water & in situ \\
\hline Total coliforms & $\mathrm{TC}$ & $\left(\mathrm{UFC} \mathrm{mL} \mathrm{m}^{-1}\right)$ & NF ISO 4832 & \begin{tabular}{|c|}
$\begin{array}{c}\text { Dissolved fraction } \\
\text { (filtered at } 0.45 \\
\mu \mathrm{m})\end{array}$ \\
\end{tabular} & Laboratory \\
\hline Faecal coliforms & $\mathrm{FC}$ & $\left(\mathrm{UFC} \mathrm{mL} \mathrm{mL}^{-1}\right)$ & NF ISO 4832 & \begin{tabular}{|c|}
$\begin{array}{c}\text { Dissolved fraction } \\
\text { (filtered at } 0.45 \\
\mu \mathrm{m})\end{array}$ \\
\end{tabular} & Laboratory \\
\hline Temperature & $\mathrm{T}$ & ${ }^{\circ} \mathrm{C}$ & $\begin{array}{c}\text { Integrated temperature } \\
\text { probe of the combined } \mathrm{pH} \\
\text { electrode sensor }\end{array}$ & Whole water & in situ \\
\hline
\end{tabular}

*NTU $=$ Nephelometric Turbidity Units

\subsection{Expression of Experimental Results}

\subsubsection{Value of $\mathbf{E}$}

To characterize the extent of the decontamination for individual contaminants (e.g., coliform, nitrate, turbidity), the effectiveness of the treatment (E) or attenuation percentage was calculated as follows (Equation (1)):

$$
\mathrm{E}=\left[1-\left(\mathrm{C} / \mathrm{C}_{0}\right)\right] \times 100[\%]
$$

where $\mathrm{C}$ is the concentration after the experiment in the effluent concentration, and $\mathrm{C}_{0}$ the initial aqueous influent concentration. The effectiveness comprises adsorption in the filter and possible other reactions that may occur during water throughput. 


\subsubsection{Hydraulic Conductivity}

Changes of the hydraulic conductivity (permeability) were characterized by calculating the percentage of the relative permeability $\varphi$ at each filtration event relative to the initial value of the hydraulic conductivity $\varphi_{0}$ (Equation 2):

$$
\varphi=100 \times \varphi / \varphi_{0}[\mathrm{vol} . \%]
$$

\subsection{Results and Discussion}

\subsubsection{Results}

\subsubsection{Hydraulic conductivity}

Figure 8 and Table 4 (row 3) summarize the changes of relative filtration rate $(\varphi)$ in the investigated filter. The results of a previous experiment for 6 months with a 50:50 $\mathrm{Fe}^{0} / \mathrm{sand}$ volumetric ratio (experiment 1) are also shown. It is seen that the filter in experiment 1with the same $\mathrm{Fe}^{0}-\mathrm{SW}$ was not sustainable as an almost $90 \%$ permeability loss was observed. The present experiment with a $10 \% \mathrm{Fe}^{0}$ (vol/vol) was designed accordingly (experiment 2 ). The results of experiment 1 depict the typical profile of permeability loss in $\mathrm{Fe}^{0}$-based filtration systems (Westerhoff and James (2003), Mackenzie et al. (1999) with the $\varphi$ value dropping very abruptly. This behavior can be attributed to a local formation of a cake (more spongy, stratified form) within the filter (Santisukkasaem and Das 2019). Clearly most of the filter material stays still porous, but the inter-connectivity is suppressed in the domain where cake is formed. This is a testimony that the used $\mathrm{Fe}^{0}$ ratio is too high (Domga et al. 2015).

The progressive decrease of the $\varphi$ values observed in this work (41.5\% in 12 months) was mainly attributed to iron corrosion products. This assumption is supported by results of George and Ahammed (2019) who performed similar experiments but with three individual systems (BSF and $\mathrm{Fe}^{0}$-amended BSF) for 4 months. The $\varphi$ values were 50.0\%, 42.9\%, and $15.6 \%$ for the systems $\mathrm{Fe}^{0}$-nails/sand, $\mathrm{Fe}^{0}$ - scrap/sand, and $\mathrm{BSF}$ respectively. While George and Ahammed (2019) are still speculating about the presence of $\mathrm{Fe}^{0}$ as cause of decline in flow rate, the present study was designed to verify the textbook knowledge that iron corrosion is a volumetric expansive process (Landolt 2007), which implies that systems with lower $\mathrm{Fe}^{0}$ ratios are more permeable (Tepong-Tsinde et al. 2015a, Domga et al. 2015, Caré et al. 2013). The design tested in this work, a $\mathrm{Fe}^{0} \mathrm{SW}$ filter sandwiched between two BSF filters, was an attempt to prolong the service life of the filter by consuming dissolved $\mathrm{O}_{2}$ in the first BSF, therefore operating under $\mathrm{O}_{2}$ depleted conditions and avoiding rapid system clogging 
(Tepong-Tsinde et al. 2015a, Noubactep et al. 2012). The second BSF was used as Fe scavenger to fix iron escaping from the $\mathrm{Fe}^{0}$ filter. The results of George and Ahammed (2019) confirmed the $\mathrm{O}_{2}$ scavenging nature of both BSF and $\mathrm{Fe}^{0}$ filters. Westerhoff and James (2003) also used hybrid $\mathrm{Fe}^{0}$ /sand layers as $\mathrm{O}_{2}$ scavengers to sustain the efficiency of $\mathrm{Fe}^{0} / \mathrm{H}_{2} \mathrm{O}$ systems.

The qualitative similitude between this work and that of George and Ahammed (2019), Mackenzie et al. (1999) and Westerhoff and James (2003) should not be overemphasized. This study used $300 \mathrm{~g}$ of $\mathrm{Fe}^{0} \mathrm{SW}$ making up a volumetric ratio of $10 \%$ while George and Ahammed (2019) used $7.5 \mathrm{~kg}$ of mild steel nails and the same mass of iron filing scrap uniformly mixed with sand throughout the reactive layer (Tab. 4). Given differences in key characteristics including density, form, intrinsic reactivity, and size of the zerovalent iron used, a quantitative comparison is difficult or even impossible. Obviously, under the respective operative conditions, the permeability loss at the end was acceptable.

The results achieved herein are more comparable to those of Bradley et al. (2011). The authors used a different grade of steel wool $(\mathrm{d}=25 \mu \mathrm{m}$ vs. $50 \mu \mathrm{m}$ herein) in the same volumetric percentage (10\%) and reported a completed SW depletion after 170 days (almost 6 months). Upon $\mathrm{Fe}^{0}$ depletion, the $\mathrm{SW}$ filter performed worse than the parallel operating BSF. This key observation was postulated by Noubactep et al. (2012) and considered while designing the system tested by Tepong-Tsindé et al. (2015a). In fact, $\mathrm{O}_{2}$ depleted by $\mathrm{Fe}^{0}$ is essential for the formation of the biofilm (Schmutzdecke), and pore filling by iron corrosion products have created preferential flow paths (Miyajim 2012). 


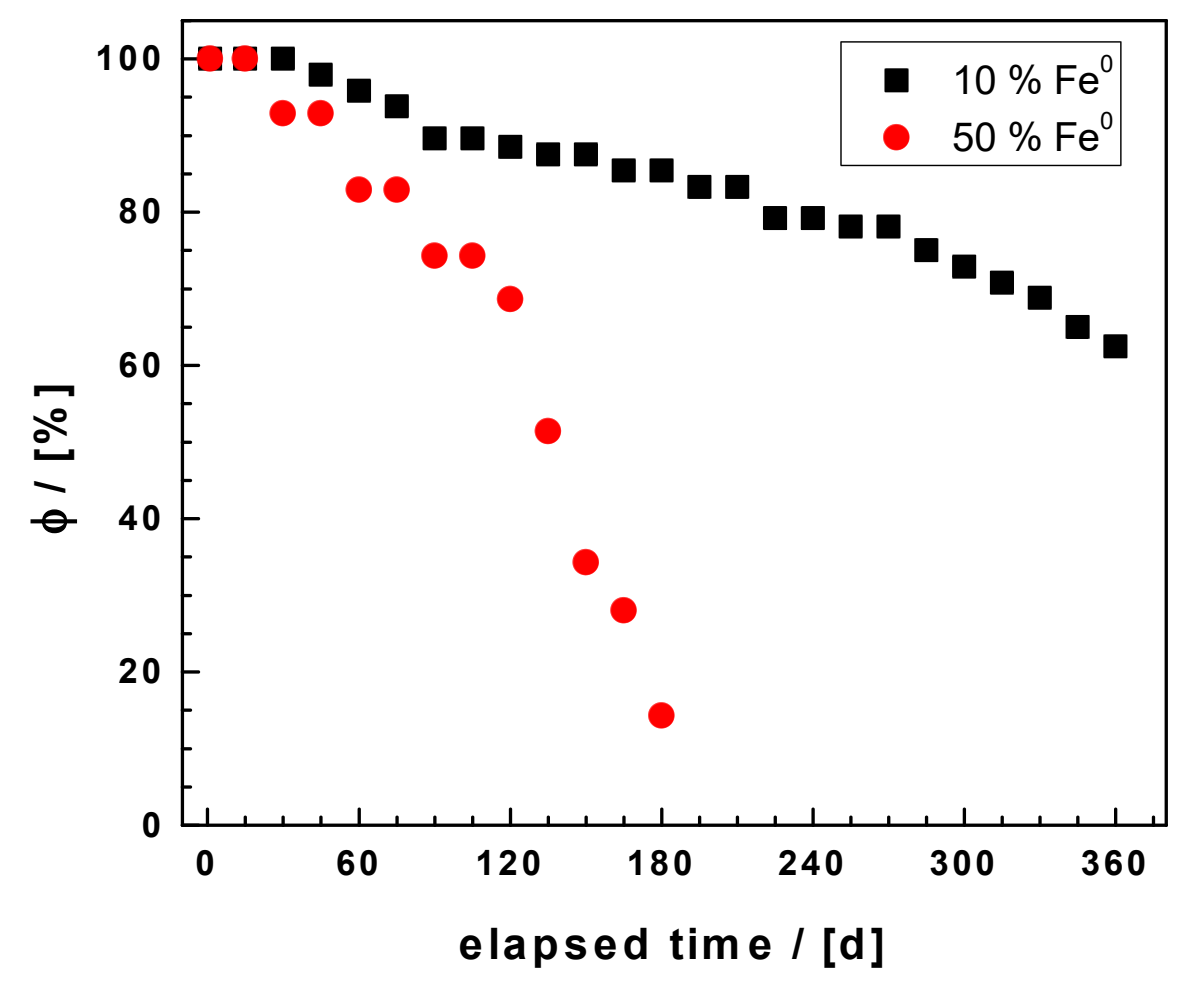

Figure 8: Flow rate variation over the length of filter runs for the $\mathrm{Fe}^{0} \mathrm{SW}$ ratios of $50 \%$ and 10 vol.\% respectively. Experimental conditions: $800 \mathrm{~g} \mathrm{SW}$ for $50 \% \mathrm{Fe}^{0}$ and $300 \mathrm{~g} \mathrm{SW}$ for $10 \% \mathrm{Fe}^{0}$ of $\mathrm{Fe}^{0} \mathrm{SW}$ (grade 0) of $35 \mu \mathrm{m}$ fiber thickness from "Grand Menage"; filling material: sand. Column length 100 $\mathrm{cm}$, column diameter $20 \mathrm{~cm}$. The system was fed with natural well water polluted by fecal coliforms.

Lufingo (2019) recently presented the first systematic characterization of $\mathrm{Fe}^{0} \mathrm{SW}$ specimens using their own developed tool (the Phen test). His results confirm the observed trends that neither the elemental composition, the size, or the surface state alone determine the kinetics and the extent of $\mathrm{Fe}^{0}$ dissolution in aqueous solution. However, because the $\mathrm{pH}$ value was still slightly increasing at the end of the experiment, it can be considered that SW was not depleted in his tests. Assuming that each natural water should be regarded as a unique system impacting the efficiency of $\mathrm{Fe}^{0}$ filters (Naseri et al. 2017), the results achieved herein are not easily transferable to other locations with different water qualities. The authors suggest, however, that it is possible to design an efficient SW containing $10 \% \mathrm{Fe}^{0}$ (vol/vol) for use at household level. More systematic research is needed using, for example, the seven grades of $\mathrm{Fe}^{0} \mathrm{SW}$ characterized by Lufingo et al. (2019) in combination with typical model (examples of water) waters representing the most common water sources (surface water, less and more saline groundwater) [Luo et al. 2013]. 
Table 4: Characteristics of the effluent water over the testing period. The effluent iron concentration was constantly lower than the detection limit of the UV-Vis spectrophotometer $\left([\mathrm{Fe}]<0.2 \mathrm{mg} \mathrm{L}^{-1}\right)$. $\varphi$ is the water flow velocity in $\mathrm{L} \mathrm{h}^{-1}$.

\begin{tabular}{|c|c|c|c|c|c|}
\hline $\mathbf{t}$ & pH & $\Phi$ & Total coliform & Turbidity & Nitrate \\
\hline (days) & & $\left(\mathrm{L} \mathrm{h}^{-1}\right)$ & $(\mathrm{CFU} / 100 \mathrm{~mL})$ & (NTU) & $\left(\mathrm{mg} \mathrm{L}^{-1}\right)$ \\
\hline Raw water & 4.9 & - & 1,950 & 35.0 & 23,5 \\
\hline 1 & 6.6 & 20.0 & 0.11 & 1.09 & 0.21 \\
\hline 15 & 6.7 & 20.0 & 0.11 & 1.07 & 0.19 \\
\hline 30 & 6.6 & 20.0 & 0.11 & 1.00 & 0.20 \\
\hline 45 & 6.8 & 20.0 & 0.10 & 1.00 & 0.20 \\
\hline 60 & 6.8 & 19.6 & 0.10 & 1.01 & 0.15 \\
\hline 75 & 6.9 & 19.6 & 0.10 & 1.00 & 0.15 \\
\hline 90 & 6.7 & 18.8 & 0.10 & 0.99 & 0.12 \\
\hline 105 & 6.6 & 18.8 & 0.08 & 0.80 & $<0.1$ \\
\hline 120 & 6.8 & 17.9 & 0.08 & 0.90 & $<0.1$ \\
\hline 135 & 7.0 & 17.5 & 0.08 & 0.90 & $<0.1$ \\
\hline 150 & 7.1 & 17.5 & 0.08 & 0.80 & $<0.1$ \\
\hline 165 & 7.3 & 17.1 & 0.08 & 0.80 & $<0.1$ \\
\hline 180 & 7.4 & 17.1 & 0.08 & 0.80 & $<0.1$ \\
\hline 195 & 7.5 & 16.7 & 0.02 & 0.90 & $<0.1$ \\
\hline 210 & 7.5 & 16.7 & $<0.02$ & 0.90 & $<0.1$ \\
\hline 225 & 7.5 & 15.8 & $<0.02$ & 0.80 & $<0.1$ \\
\hline 240 & 7.6 & 15.8 & $<0.02$ & 0.90 & $<0.1$ \\
\hline 255 & 7.6 & 15.6 & $<0.02$ & 0.90 & $<0.1$ \\
\hline 270 & 7.7 & 15.6 & $<0.02$ & 0.80 & $<0.1$ \\
\hline 285 & 7.5 & 15.0 & $<0.02$ & 0.80 & $<0.1$ \\
\hline 300 & 7.6 & 15.8 & $<0.02$ & 0.70 & $<0.1$ \\
\hline 315 & 7.9 & 15.2 & $<0.02$ & 0.80 & $<0.1$ \\
\hline 330 & 8.1 & 13.8 & $<0.02$ & 0.70 & $<0.1$ \\
\hline 345 & 8.3 & 13.0 & $<0.02$ & 0.80 & $<0.1$ \\
\hline 360 & 8.6 & 12.5 & $<0.02$ & 0.70 & $<0.1$ \\
\hline
\end{tabular}

\subsubsection{Turbidity removal}

Table 4 (row 5) summarizes the results of turbidity removal by listing the residual turbidity; the corresponding percent removal is depicted in Figure 9. The average influent turbidity was 35 NTU. The average effluent turbidity from the system was 0.7 NTU. The average turbidity removal efficiency from the influent was $>98 \%$ during the experiment. This corroborates the results of George and Ahammed (2019) and Bradley et al. (2011) reporting about quantitative 
turbidity removal in both BSF and $\mathrm{Fe}^{0}$-amended BSF. George and Ahammed (2019) also reported that the amendment of $\mathrm{Fe}^{0}$ filters does not improve their turbidity removal efficiency. The results presented herein seem to confirm this assertion. However, the removal efficiency depends on the design and the operational conditions. In essence, $\mathrm{Fe}^{0}$ amendment should improve turbidity removal because of pore space reduction (expansive corrosion) [Domga et al. 2015].

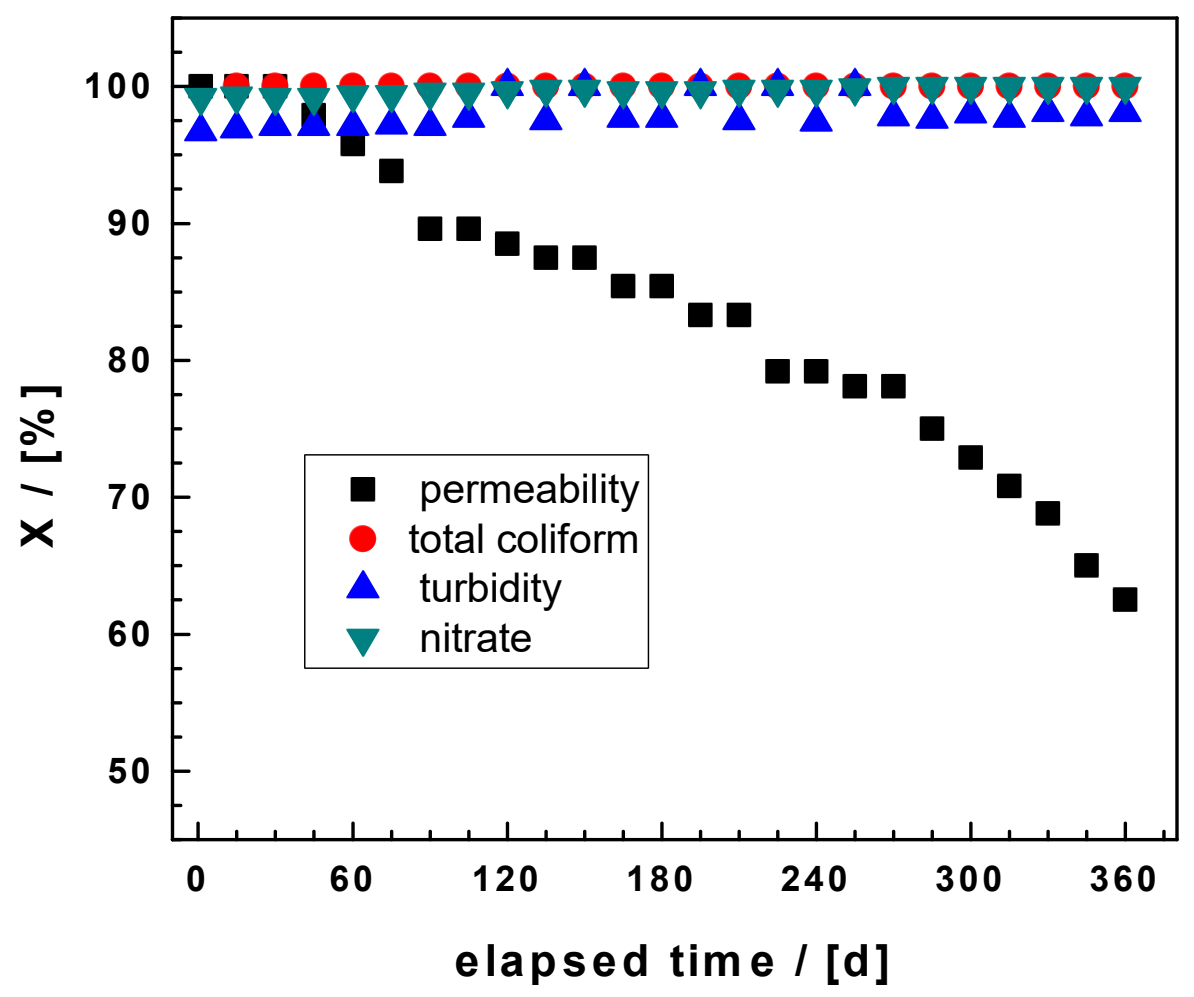

Figure 9: Permeability loss (percent) of the filter material and efficiencies of the removal of fecal coliform, turbidity, and nitrate (percent) in the effluent water over the length of filter run for the experiment with $10 \% \mathrm{Fe}^{0} \mathrm{SW}$ (vol/vol). Experimental conditions: $300 \mathrm{~g} \mathrm{SW}$ at $26 \pm 2{ }^{\circ} \mathrm{C}$; filling material: Sand; column length: $100 \mathrm{~cm}$, column diameter: $20 \mathrm{~cm}$. The system was fed by natural well water polluted by fecal coliform.

\subsubsection{Nitrate removal}

Table 4 (row 6) lists the results of $\mathrm{NO}_{3}{ }^{-}$concentration in the outlet water over time. The corresponding percent removal is presented in Figure 9. The average influent $\mathrm{NO}_{3}{ }^{-}$ concentration was $23.5 \mathrm{mg} \mathrm{L}^{-1}$. Compared to the results of George and Ahammed (2019), it is clear that $\mathrm{NO}_{3}{ }^{-}$removal mainly occurs in the $\mathrm{Fe}^{0} \mathrm{SW}$ column. In fact, the authors spiked their influent solution with $26.0 \mathrm{mg} \mathrm{L}^{-1} \mathrm{NO}_{3}{ }^{-}$and observed $\mathrm{NO}_{3}{ }^{-}$removal in all the three systems. 
The conventional BSF showed the lowest $\mathrm{NO}_{3}{ }^{-}$removal. The $\mathrm{NO}_{3}{ }^{-}$removal in BSF is welldocumented, but the removal is never quantitative (Nakhla and Faroow 2003, Murphy et al. 2010). Thus, although the influent water used herein was not additionally spiked by $\mathrm{NO}_{3}{ }^{-}$ (Table 2), its removal was quantitative and occurred presumably in the $\mathrm{Fe}^{0} \mathrm{SW}$ column (Westerhoff and James 2003).

The mechanism of $\mathrm{NO}_{3}{ }^{-}$removal is complex and implies microbiological process in the BSF units (George and Ahammed 2019, Murphy et al. 2010) and both abiotic and biotic processes in the $\mathrm{Fe}^{0} \mathrm{SW}$ unit (Westerhoff and James 2003, George and Ahammed 2019).

\subsubsection{4 $\quad \mathrm{pH}$ value and iron breakthrough}

Table 4 lists the $\mathrm{pH}$ values (row 2) in the system's effluent. No iron breakthrough was observed. The iron concentration was constant below the detection limit of $0.2 \mathrm{mg} \mathrm{L}^{-1}$. The $\mathrm{pH}$ value progressively increased within the operational time and reached 8.5 at the end of the experiments. The iron concentration was monitored to check whether any breakthrough occurred. The results showed that the second BSF quantitatively fixed iron for the whole duration of the experiment. Systems without scavenging BSF contain higher iron concentrations (Westerhoff and James 2003, Heimann et al. 2018). For example, Westerhoff and James (2003) reported on up to $6 \mathrm{mg} \mathrm{L}^{-1} \mathrm{Fe}$ in their effluent solutions. The very low iron concentration recorded herein is also in agreement with the $\mathrm{pH}$ dependent solubility of $\mathrm{Fe}$ hydroxides (Liu and Millero 1999) as discussed for the "Fe ${ }^{0}$ remediation" literature by Ghauch (2015). The fact that no iron breakthrough is observed herein suggests that the amount of iron (mainly $\mathrm{Fe}^{2+}$ ) escaping column 2 could not saturate the amount of sand in the second BSF. $\mathrm{Fe}^{2+}$ is adsorbed onto sand by pure electrostatic interactions (Btatkeu-K et al. (2014a and 2014b)).

\subsubsection{Removal of coliforms}

Table 4 (row 4) and Figure 9 show a very pronounced reduction in total coliform concentration over the whole operation time: There was a quantitative coliform removal already at the beginning of the experiment ( $\mathrm{E}>99.99 \%$ ), and this trend kept through to the end (one year). This is due to three synergy processes: (i) formation of the biofilm in BSF, (ii) in situ generation of iron corrosion products (FeCPs), and (iii) reduction of the flow rate. As discussed in Section 4.9.1.1, accumulation of FeCPs reduces the porosity and the permeability, what improves coliform removal through adsorption (Bradley et al. 2011, Noubactep et al. 2012). It is essential to recall that the intrinsic bacterial inactivation capacity 
of $\mathrm{Fe}^{0}$ was already reported in the 19th century (Bischof $(1873,1877,1878)$, Notter $(1878)$, Hatton (1881), Bache (1891), Tweeddale (1898), Baker (1934), and Leffmann(1991)) and has been independently demonstrated in the recent " $\mathrm{Fe}^{0}$ remediation" research (Bojic et al. 2001, Lee et al. 2008, Diao and Yao (2009), Crampon et al. 2019, Hu et al. 2019, Sun et al. 2019). In the 19th century, quantitative pathogen removal in $\mathrm{Fe}^{0}$ filters was demonstrated before the nature of individual bacteria was established. On the contrary, current research efforts are trying to demonstrate the efficiency of $\mathrm{Fe}^{0}$ filters for pathogen removal on a case-by-case basis (You et al. 2005, Ingram et al. 2011, Shi et al. 2012, Marik et al. 2019).

\subsubsection{Discussion}

Previous studies testing contaminant removal from water by using $\mathrm{Fe}^{0}$-based column household water filters are numerous (Naseri et al. 2017). They were mostly designed to test diverse $\mathrm{Fe}^{0}$ specimens for the removal of selected contaminants (George and Ahammed 2019) and/or to compare the efficiency of $\mathrm{Fe}^{0}$ filters to that of other systems, including BSFs (Noubactep et al. 2012). In a recent review, $\mathrm{Hu}$ and Noubactep (2019c) compiled available results to demonstrate the suitability of $\mathrm{Fe}^{0}$ filters for water treatment. However, results from independent research are difficult to compare to each other. This section illustrates this difficulty based on selected references on the removal of pathogens from water. The six selected publications (Table 6) were not only focused on pathogen removal, they were selected to reflect the large diversity of experimental designs. The focus is not on achieved results but on operational conditions. They determine the results, but are rarely considered while discussing achieved results (Naseri et al. 2017).

Six operational parameters were selected for this discussion: (i) the column dimensions (D and $\mathrm{L}$ ), (ii) the $\mathrm{Fe}^{0}$ /sand ratio, (iii) the initial flow velocity $\left(\mathrm{F}_{0}\right)$, (iv) the experimental duration (t), (v) the $\mathrm{Fe}^{0}$ type, and (vi) the used $\mathrm{Fe}^{0}$ mass. Only $\mathrm{Fe}^{0}$ sand ratio and the $\mathrm{Fe}^{0}$ type were specified by all six publications. The used volumetric $\mathrm{Fe}^{0}$ ratio varied between $10 \%$ and $50 \%$, while $\mathrm{Fe}^{0} \mathrm{SW}$ and granular materials were used. Concerning the column dimensions, smallscale columns and columns pertinent to pilot-scale tests were used while the flow velocities differed by more than three orders of magnitude. Lastly, 0.15 to $23 \mathrm{~kg}$ of $\mathrm{Fe}^{0}$ materials were used for operational duration varying from 10 to 365 days. There is no scientific basis to compare results from such experiments, particularly because the kinetics of iron corrosion are never linear, and the systems are dynamic in nature ( $\mathrm{Hu}$ and Noubactep 2019c).

Table 5 compiles some results of six selected peer- reviewed articles with column experiments for the removal of biological contamination including column dimension (length 
and diameter), the $\mathrm{Fe}^{0}$ to sand ratio, the initial flow velocity $\left(\varphi_{0}\right)$, the experimental duration (t), $\mathrm{Fe}^{0}$ type, and the used $\mathrm{Fe}^{0}$ mass it is seen that one paper has not explicitly given the experimental duration. Shi et al. (2012) used the number of pore volumes in their discussion. Two papers tested periods exceeding four months (120 days). In general, there is a large variability of the considered operational parameters. * is given in weight/weight; 'n.s.' stands for not specified and 'non SI' for units given in a not known system, for example ' 2 " x 2' PVC plain-end-pipe'.

Table 5: Summary of parameters of column experiments for the removal of biological contamination compared with data from six selected peer-reviewed articles.

\begin{tabular}{|c|c|c|c|c|c|c|c|}
\hline $\mathbf{L}$ & $\mathbf{D}$ & $\mathbf{F e}^{\mathbf{0}}$ to sand & $\boldsymbol{\Phi}_{\mathbf{0}}$ & $\mathbf{t}$ & $\mathbf{F e}^{\mathbf{0}}$ type & miron & Reference \\
\hline$(\mathrm{cm})$ & $(\mathrm{cm})$ & $(\mathrm{vol} / \mathrm{vol})$ & $\left(\mathrm{L} \mathrm{h}^{-1}\right)$ & $($ days $)$ & & $(\mathrm{kg})$ & \\
\hline 10 & 3.8 & $50 / 50$ & 0.06 & 10 & granular & 0.15 & You et al. 2005 \\
\hline 20 & n.s. & $10 / 90$ & 0.03 & 300 & SW & 0.26 & Bradley et al. 2011 \\
\hline 0.77 & 0.14 & $50 / 50^{*}$ & n.s. & 15 & granular & 23.0 & Ingram et al. 2011 \\
\hline 10 & 3.8 & $50 / 50$ & 4.38 & n.s. & granular & n.s. & Shi et al. 2012 \\
\hline non SI & non SI & $35 / 65$ & 222 & 154 & granular & n.s. & Marik et al. 2019 \\
\hline n.s. & n.s. & n.s. & n.s. & 120 & granular & 7.5 & George et al. 2019 \\
\hline 100 & 20 & $10 / 90$ & 20.4 & 365 & SW & 0.30 & This study \\
\hline
\end{tabular}

* is given in weight/weight; "n.s." stands for not specified and "non SI" for units given in a not known system, for example " 2 " $\times 2$ PVC plain-end pipe".

Table 5 additionally shows a general weakness of the research projects undertaken to date: the long-term efficiency of $\mathrm{Fe}^{0}$ systems for water treatment has not been investigated. Experiments designed for more than three months are rare. The time span of most tests is rather counter-intuitive in a context where long-term monitoring data is urgently needed $(\mathrm{Hu}$ and Noubactep 2019c, Hu et al. 2019).

\subsubsection{Significance of the Results}

$\mathrm{Fe}^{0}$ materials have demonstrated their suitability for the design and dissemination of affordable, efficient, and sustainable safe drinking water provision systems over the past 170 years (Devonshire 1890, Tucker 1892, Lauderdale and Emmons 1951, Hussam 2009, Banerji and Chaudhari 2017). For the most recent success stories in decentralized systems, Hussam (2009) used a proprietary material and Banerji and Chaudhari (2017) used affordable iron nails. Progress in the large-scale realization of these and similar devices has been highly 
impeded by the lack of easy transferable designs. Using universally available steel wool $\left(\mathrm{Fe}^{0}\right.$ SW) in this study was a step toward achieving a universal access to safe drinking water (Noubactep et al. 2009, Ndé-Tchoupé et al. 2015, Tepong-Tsindé et al. 2015a, Nanseu-Njiki et al. 2019, Ndé-Tchoupé 2019, Yang et al. 2020).

Based on a concept presented by Noubactep et al. (2009) and a mathematical model reasonably predicting optimal $\mathrm{Fe}^{0} /$ sand ratio for a sustainable filter (Caré et al. 2013, Domga et al. 2015), the present work has tested a volumetric $\mathrm{Fe}^{0} /$ sand ratio of 10:90 (300 $\mathrm{g} \mathrm{Fe}^{0} \mathrm{SW}$ plus $14,200 \mathrm{~g}$ coarse sand) and obtained a filter that is able to treat well water polluted with pathogens for one year while depicting a permeability loss of only $41.5 \%$. After one year the system was still capable of producing $200 \mathrm{~L}$ water per day, with an acceptable flow velocity $\left(8.33 \mathrm{~L} \mathrm{~h}^{-1}\right)$. This amount is far above the water needs of an average family. Assuming that each person needs $8 \mathrm{~L}$ water per day for drinking and cooking, the designed filter can supply 25 people with safe drinking water, whether they are living in a small village, an urban slum, or a modern city. The filter is relatively easy in design. The most challenging task is to homogeneously build up the reactive zone consisting of $\mathrm{Fe}^{0} \mathrm{SW}$ and sand. A dry packing approach in small lots was adopted. For future works, however, a wet packing approach as suggested by Sleiman et al. (2016) should be tested. These authors pre-wetted the $\mathrm{Fe}^{0}$ /sand mixture to facilitate homogeneous $\mathrm{Fe}^{0}$ distribution in the column material.

The most important result here is that a column containing $10 \%$ vol. $\%$ of $\mathrm{Fe}^{0} \mathrm{SW}$ and 90 vol.\% of sand corresponding to just 2 wt. $\%$ of $\mathrm{Fe}^{0}$ and fed with a turbid natural water was still permeable after one year of operation. This result might not be reproduced by another $\mathrm{Fe}^{0} \mathrm{SW}$ or a different water source, but the $\mathrm{Fe}^{0}$ /sand ratio can be further decreased (and the column length increased) until a satisfactory balance is identified for each specific case. Sleiman et al. (2016) used just $1 \%$ of $\mathrm{Fe}^{0}$ in their systems while Erickson et al. (2017) hardly used more than $5 \%(\mathrm{w} / \mathrm{w})$. Clearly, there is room for adjusting the operational conditions to any site-specific situation. Where necessary, additional units made of affordable materials should be added to remove contaminants that are not well addressed by $\mathrm{Fe}^{0} / \mathrm{H}_{2} \mathrm{O}$ systems such as some radioactive substances or fluoride (Lauderdale and Emmons 1951, Gwenzi et al. 2017). 


\section{Chapter 5}

\section{General discussion}

This chapter corresponds to the general discussion of the Thesis. 


\subsection{Significance of the results}

The present work is a continuation of an effort started some twelve years ago with the aim to make $\mathrm{Fe}^{0}$ filters a universal solution for safe drinking water provision (Noubactep and Woafo 2008, Noubactep et al. 2009, Noubactep and Schöner 2010a). One initial goal was to design a household filter which can operate for at least six months without any maintenance (Noubactep et al. 2009). The concept was rooted on experimental evidence achieved in the framework of the development of $\mathrm{Fe}^{0}$-based permeable reactive barriers for ground water remediation (O'Hannesin and Gillham 1998, Richardson and Nicklow 2002, Henderson and Demond 2007) where $\mathrm{Fe}^{0}$ used as filter material can quantitatively remove biological and chemical contaminants from polluted waters.

An initial survey of the literature revealed that $\mathrm{Fe}^{0}$ household filters have been often tested for arsenic removal (Khan et al. 2000, Ngai et al. 2006, Hussam and Munir 2007, Ngai et al. 2007). Reviewing the existing literature, it was observed that $\mathrm{Fe}^{0}$ filters designed for As removal eliminate beside arsenic up to 24 other contaminants including inorganic and organic components as well as pathogens (Tuladhar and Smith 2009). This observation was in tune with several previous works which have tested $\mathrm{Fe}^{0}$ for water treatment on a contaminant by contaminant basis (Bojic et al. 2001, Richardson and Nicklow 2002, Bojic et al. 2004, Purenovic et al. 2004, Bojic et al. 2007, Bojic et al. 2009). In particular, Bojic et al. (2001, 2004, 2007, 2009) clearly demonstrated that heavy metals, halogenated carbons and pathogens are removed by flocculation or coagulation in the vicinity of the $\mathrm{Fe}^{0}$ surface. This view is indeed known to scientists since the 1850s (Bischof 1873, Tucker 1892, Baker 1934, van Craenenbroeck 1998, Mwakabona et al. 2017, Antia 2020, Cao et al. 2020). Clearly, the corrosion products of $\mathrm{Fe}^{0}$ are contaminant scavengers but the kinetics of iron corrosion is not a linear function of time, but rather depends on a myriad of operational parameters including the $\mathrm{Fe}^{0}$ intrinsic reactivity, temperature, and water chemistry (Cao et al. 2020, Ogata et al. 2020, Müller et al. 2020, Yang et al. 2020, Lanet et al. 2021, Yang et al. 2021). Moreover, iron corrosion is a volumetric expansive process (Whitney 1903, Pilling and Bedworth 1923). The next question to answer was which species shall be used to test $\mathrm{Fe}^{0}$ filters? An operational indicator was one needed. Methylene blue (MB) was identified as a tracer to characterize the reactivity of $\mathrm{Fe}^{0} / \mathrm{H}_{2} \mathrm{O}$ systems (Miyajima 2012, Miyajima and Noubactep 2013). Mitchell et al. (1955) in their historical work already demonstrated the suitability of MB for this aim by showing that sand is an excellent adsorbent for MB but iron oxide-coated sand has practically no adsorptive affinity to MB. In order words, by rationally selecting the amount of $\mathrm{Fe}^{0}$ and sand in a system, it is possible to reconstruct the extent of sand coating by 
in-situ generated iron corrosion products (Xiao et al. 2020, Yang et al. 2021). The extent of porosity loss and the related permeability loss can also be evaluated (Njaramba et al. 2021, Yang et al. 2021). Permeability loss is due to initial pore space saturation as a result of the expansion of in-situ generated iron corrosion products which rapidly occurs under conditions accelerating the corrosion process (e.g. presence of chloride ions) (Zhao et al. 2011, Stefanoni et al. 2018).

\subsubsection{The validation of the MB discoloration method}

This thesis has particularly validated the suitability of MB to characterize the effects of chloride ions on the efficiency of $\mathrm{Fe}^{0} / \mathrm{H}_{2} \mathrm{O}$ systems for contaminant removal. In presence of chloride ions, aqueous iron corrosion is accelerated rendering $\mathrm{Fe}$ corrosion products abundantly available in the system. MB was observed to be weakly adsorbed onto the positively charged in-situ generated iron oxides (partly in-situ coated on sand). This confirms the ion-selective nature of $\mathrm{Fe}^{0} / \mathrm{H}_{2} \mathrm{O}$ systems reported by Phukan et al. (2015). Previous studies tested $\mathrm{Fe}^{0}$ as removing agent for dyes mostly in wastewater treatment (Miyajima and Noubactep 2013 and ref. cited therein). In successfully testing dyes in general and MB in particular as operative indicators for the characterization of $\mathrm{Fe}^{0}$-based systems, the practicability and cost-efficiency of experimental device using dyes in general (Noubactep 2009, Phukan et al. 2015) is made available for the investigation of various aspects relevant for the design of $\mathrm{Fe}^{0}$ filters. This aspect is important for scientific research under financially less favorable conditions (e.g. developing countries) (Cao et al. 2021a, 2021b, 2021c).

The MB method has for instance already been used to investigate the impact of the $\mathrm{Fe}^{0}$ /sand ratio on the durability of $\mathrm{Fe}^{0}$ filters (Miyajima 2012, Miyajima and Noubactep 2013). Results confirmed theoretical predictions that no pure $\mathrm{Fe}^{0}$ filter is sustainable and that the volumetric $\mathrm{Fe}^{0}$ proportion should not exceed $51 \%$. Many field applications have fortuitously used similar $\mathrm{Fe}^{0}$ ratios. However, the objective in using sand as admixing agent was to save iron costs (Mackenzie et al. 1999, Westerhoff and James 2003, Kaplan and Gilmore 2004, Bi et al. 2009). In other words, the MB method has demonstrated that admixing $\mathrm{Fe}^{0}$ with inert (e.g. pumice, sand) or reactive materials (e.g. $\mathrm{MnO}_{2}$ ) is a prerequisite for durable systems (Ullah et al. 2020, Njaramba et al. 2021). The next question to answer is: Why are sustainable household filters not been yet designed? 


\subsubsection{Reasons for existing designs failure}

The reasons for the failure of existing designs are numerous as summarized by Noubactep et al. (2012). Beside inappropriate $\mathrm{Fe}^{0} /$ sand ratios, the use of very different types of $\mathrm{Fe}^{0}$ materials was regarded as the main cause of lack of transferable results. This situation is exacerbated by experiments lasting for just some few weeks or months while there is a large uncertainty on the long-term corrosion rate (Moraci et al. 2016, Noubactep 2016, Naseri et al. 2017, Yang et al. 2020, Yang et al. 2021). The present work has successfully tested steel wool, a readily available $\mathrm{Fe}^{0}$ material for an experimental duration of 12 months. There are seven (7) grad of steel wool (Lufingo et al. 2019, Hildebrant et al. 2020) of which grade 000 (extra fine $-\mathrm{d} 1=25 \mu \mathrm{m}$ ) was successfully tested for pathogen removal until material depletion after some 8 months (Bradley et al. 2011). The grade of $\mathrm{Fe}^{0} \mathrm{SW}$ (fine) tested herein corresponds to twice larger filaments (fine $-\mathrm{d}_{2}=50 \mu \mathrm{m}$ ) than those tested by Bradley et al. (2011) and could clean polluted water for one year without material exhaustion.

\subsection{Improving household $\mathrm{Fe}^{0}$-based filters design}

The results of this study suggest that an effective and sustainable household $\mathrm{Fe}^{0}$-based filter for a large family (e.g. $\geq 10$ people) in the developing world should comprise: (i) at least one polyethylene tank ( $\geq 1000 \mathrm{~L})$ installed beside the water treatment plant for raw water storage; (ii) a slow sand filter (SSF) for pre-filtration (e.g. for the removal solid matters); (iii) a $\mathrm{Fe}^{0} /$ sand filter (which is the unit in which the reactive filtration effectively takes place), eventually (iv) SSF for the removal of $\mathrm{Fe}$ escaping from the $\mathrm{Fe}^{0} /$ sand filter; and finally (vi) a polyethylene tank to collect and store the produced drinking water. The number of filters in series depends on the extent of the raw water contamination and the required quality of potable water (Notter 1878, Naseri et al. 2017, Yang et el. 2020. Huang et al. 2021b).

\subsubsection{Considerations for efficient household $\mathrm{Fe}^{\mathbf{0}}$-based on-site filters}

A minimum of six variables including $\mathrm{Fe}^{0}$ intrinsic reactivity, $\mathrm{Fe}^{0}$ shape and size, $\mathrm{Fe}^{0}$ content (amount and proportion), solution $\mathrm{pH}$, and the redox potential have been demonstrated to have an important impact on the decontamination efficiency of $\mathrm{Fe}^{0} /$ sand filters (Tepong-Tsindé et al. 2015, Ndé-Tchoupé et al. 2015, Naseri et al. 2017, Huang et al. 2021b). This makes comparisons and correlation of available data difficult. However, a profound analysis of the fundamental reactions involved in the present work, together with some recently obtained design criteria (Noubactep 2012, Nde-Tchoupé et al. 2015, Naseri et al. 2017), have brought out a number of important considerations which may simplify design efforts. They can be 
summarized as (i) use only volumetric $\mathrm{Fe}^{0}$ ratios $\leq 50 \%$; (ii) characterize the intrinsic reactivity of used $\mathrm{Fe}^{0}$; (iii) use as little $\mathrm{Fe}^{0}$ as necessary for reliable observations; and (iv) avoid too short experimental times. Testing $\mathrm{Fe}^{0}$ materials at pilot scale can be summarized in the following: (i) test several well-characterized $\mathrm{Fe}^{0}$ materials; (ii) test several $\mathrm{Fe}^{0} / \mathrm{sand}$ ratios $\left(\mathrm{Fe}^{0}<50 \%\right.$ ), for a given $\mathrm{Fe}^{0}$ material and a $\mathrm{Fe}^{0} /$ sand ratio; (iii) test the number of each unit for satisfactory water treatment; (iv) insert wood charcoal units before $\mathrm{Fe}^{0} /$ sand units; (v) partly or totally replace sand by porous materials including: anthracite, gravel, $\mathrm{MnO} 2$ and pumice.

\subsubsection{Containment}

The household $\mathrm{Fe}^{0}$-based filter designed and presented herein is an open architecture which could be constructed, modified, adapted, and improved on a site-specific basis. Filters containers can be locally built, for example from stackable prefabricated concrete rings commonly used for tank construction. Commercially available plastic tanks can be also modified and used. Appropriately skilled masons can construct custom ferro-cement tanks. In this case the dimensions should enable facile filling of filter media and routine maintenance including the removal/replacement of all materials. Some cover material (lid) should be used to exclude sunlight and inhibit the growth of photosynthetic microorganisms (algae, cyanobacteria) in the system. Tank tops should be wrapped in fine mesh screening to prevent entrance of insects, bird droppings, leaves, and bits of debris, etc. into the system.

\subsection{Designing functioning $\mathrm{Fe}^{\mathbf{0}}$-based filters}

This thesis, was initiated to enable the design of $\mathrm{Fe}^{0}$ filters able at operating for 12 months without clogging nor material depletion. This objective was largely achieved: (i) a filter with a 1:1 volumetric $\mathrm{Fe}^{0}$ :sand ratio clogged after six months, while (ii) a second filter with a 1:9 volumetric $\mathrm{Fe}^{0}$ :sand ratio was still permeable after 12 months. To the best of the author's knowledge, this is the first study based on the science (Hu et al. 2019) of the system that has lasted for 12 months. Comparable studies have just lasted for some few months (George and Ahammed 2019, Njaramba et al. 2021) and are certainly of low operational value as clogging is very rapid once it starts (Westerhoff and James 2003). In other words, this work presents a prototype for a functioning household filter, provided the raw water is of comparable quality (e.g. E coli level, $\mathrm{NO}_{3}{ }^{-}$level, $\mathrm{pH}$ value). This prototype can be adapted to the treatment of more or less contaminated waters. A viable prototype for $\mathrm{Fe}^{0}$ filters using steel wool is presented. The tested 1:9 volumetric $\mathrm{Fe}^{0}$ :sand ratio can be also optimized for wastewater 
treatment and community-scale drinking water systems. Erickson et al. (2012) and Wakatsuki et al. (1993) used far lower $\mathrm{Fe}^{0}$ :sand ratios $(<5 \%)$ in this $\mathrm{Fe}^{0}$-based filters for wastewater treatment.

The other issue successfully addressed in this thesis is the mechanism of $\mathrm{NO}_{3}{ }^{-}$removal by $\mathrm{Fe}^{0}$. While active researchers are still reporting on " $\mathrm{NO}_{3}{ }^{-}$removal by reducing $\mathrm{Fe}^{0 "}$ (Khalil et al. 2018, Liu and Wang 2019. Kodikara et al. 2020, Villen-Guzman et al. 2020), the results of this work clearly demonstrate that the amount of removed $\mathrm{NO}_{3}{ }^{-}$is far larger than the $\mathrm{Fe}^{0}$ amount initially available in the system. In fact, during the 12 months $204 \mathrm{~g} \mathrm{of} \mathrm{NO}_{3}^{-}$were removed, which would have necessitated $1102 \mathrm{~g}$ of $\mathrm{Fe}^{0}$. However, the total amount of $\mathrm{Fe}$ available was $300 \mathrm{~g}$.

In fact, $\mathrm{NO}_{3}{ }^{-}$is reduced by $\mathrm{Fe}^{2+}$ from $\mathrm{Fe}^{0}$ oxidative dissolution. The oxidation of $\mathrm{Fe}^{2+}$ to $\mathrm{Fe}^{3+}$ releases one mole of electrons (Eq. 5.3-1) while the oxidation of one mole of $\mathrm{N}_{2}$ to $\mathrm{NO}_{3}{ }^{-}$ releases 10 electrons (Eq. 5.3-2). Eq. 5.3-3 gives the balance for the reduction of $\mathrm{NO}_{3}{ }^{-}$by $\mathrm{Fe}^{2+}\left(\right.$ from $\left.\mathrm{Fe}^{0}\right)$.

$$
\begin{aligned}
& \mathrm{Fe}^{2+} \Leftrightarrow \mathrm{Fe}^{3+}+\mathrm{e}^{-} \\
& 2 \mathrm{NO}_{3}{ }^{-}+10 \mathrm{e}^{-}+12 \mathrm{H}^{+} \Leftrightarrow \mathrm{N}_{2}+6 \mathrm{H}_{2} \mathrm{O} \\
& 10 \mathrm{Fe}^{2+}+2 \mathrm{NO}_{3}{ }^{-}+12 \mathrm{H}^{+} \Rightarrow 10 \mathrm{Fe}^{3+}+\mathrm{N}_{2}+6 \mathrm{H}_{2} \mathrm{O}
\end{aligned}
$$

In this study, $\mathrm{N}_{2}$ was not quantified; it is just assumed that the reduction of $\mathrm{NO}_{3}{ }^{-}$(to $\mathrm{N}_{2}$ ) is quantitative. From a pure kinetic perspective, it is even not likely that this reaction can be quantitative but discussing this issue is over the scope of this work. It suffices to elegantly exclude abiotic reduction by $\mathrm{Fe}^{0}$ as relevant reaction mechanism. These results clearly showed that $\mathrm{NO}_{3}{ }^{-}$microbial degradation occurred in the system and was event very significant. The importance of microbial activity in $\mathrm{Fe}^{0}$ filters corroborates the view that the long-term permeability is the main issue of $\mathrm{Fe}^{0}$-based filters (Naseri et al. 2017, Noubactep 2021, Njaramba et al. 2021, Huang et al. 2021b, Yang et al. 2021, Noubactep 2022).

The results achieved in this work (Tepong-Tsindé et al. 2019) have inspired the further development of the concept that $\mathrm{Fe}^{0}$ can be the cornerstone in global efforts for universal access to safe drinking water (Noubactep 2010, 2011). On the one hand, it is confirmed that a key issue to design functioning $\mathrm{Fe}^{0}$ filters is to spatially disperse reactive $\mathrm{Fe}^{0}$ materials in a matrix of a non-expansive aggregate (e.g. sand) (Caré et al. 2013, Domga et al. 2015). In this this regard, this work and related ones have recalled that steel wool is not an homogeny class of $\mathrm{Fe}^{0}$ materials (Lufingo et al. 2019). On the other hand, taking advantage of the modular 
multi-stage system for safe drinking water supply presented by Dr. Kearns (Kearns 2016, Huang et al. 2021b), $\mathrm{Fe}^{0}$ units can be simply replaced upon material depletion or bed clogging. In other words, despite the absence of reliable data on the long-term corrosion kinetics, functioning $\mathrm{Fe}^{0}$ filters can be designed and used. All is needed is to train user for maintenance, including the frequency of replacement. Clearly, unlike for subsurface permeable reactive barriers which need $\mathrm{Fe}^{0}$ materials able at reacting for the long term (decades) without maintenance, $\mathrm{Fe}^{0}$ based water filters can be designed to operate even for three months. In this regard, for the same polluted water, it can be expected that units with the material used herein are replaced twice less frequently than units using the $\mathrm{Fe}^{0} \mathrm{SW}$ from Bradley et al. (2011). This simple idea makes $\mathrm{Fe}^{0}$ filters probably the best design capable at enabling universal access to safe drinking water by 2030 (Naseri et al. 2017, Noubactep 2018, Yang et al. 2020, Huang et al. 2021b). In fact, the technical expertise is available since 1881 (140 years). All what is needed are systematic, and well monitored pilot-scale investigations with well-characterized $\mathrm{Fe}^{0}$-materials. 


\section{Chapter 6}

This chapter corresponds to the general conclusions of the Thesis. 


\section{General conclusions}

This dissertation provides novel insights into the dynamics of metallic iron $\left(\mathrm{Fe}^{0}\right)$ depletion in filtration systems. There is a 160 -years-old technical expertise on using $\mathrm{Fe}^{0}$ water filters for households (Antia 2020, Cao et al. 2020, Cao et al. 2021d). $\mathrm{Fe}^{0}$ water filters are affordable and easy to implement. However, designing new filters is fraught by the evidence that past research has not properly considered the sustainability as resulting from the intrinsic characteristics of $\mathrm{Fe}^{0}$ materials, in particular, the time-dependent and non-linear decrease of the corrosion kinetics. Taking steel wool $\left(\mathrm{Fe}^{0} \mathrm{SW}\right)$ as an example, several dozens of articles have presented $\mathrm{Fe}^{0} \mathrm{SW}$ as a good reactive material for water treatment without even specifying the used grade (Ndé-Tchoupé et al. 2015, Lufingo et al. 2019, Ndé-Tchoupé et al. 2019). In other words, the $\mathrm{Fe}^{0}$ filtration technology has been developed with little attention to its sustainability, which is indeed a pivotal factor in the implementation of any real applications. Clearly, despite plentiful availability of data, the emerging technology of $\mathrm{Fe}^{0}$ filters cannot be quantitatively assessed due to inhomogeneity of operational conditions, including the used $\mathrm{Fe}^{0}$ sand ratio and the experimental duration. As far as the experimental duration is concerned, only Bradley et al. (2011) have tested a $\mathrm{Fe}^{0} \mathrm{SW}(\mathrm{d}=25 \mu \mathrm{m})$ for ten months and realized a material depletion after eight months. A coarser $\mathrm{Fe}^{0} \mathrm{SW}(\mathrm{d}=50 \mu \mathrm{m})$ is tested herein for 12 months.

This work describes conditions for a water filter design and includes the results from a pilot study of a household filter in Douala (Cameroon). The presented $\mathrm{Fe}^{0}$-based filter is an innovation that combines two proven water treatment techniques: (i) removal of microbes by biological sand filtration (BSF) process and (ii) contaminant adsorption and co-precipitation with iron oxide-hydroxides. The BSF, preceding the $\mathrm{Fe}^{0} /$ sand layer, additionally contributed to lower the $\mathrm{O}_{2}$ level, thus sustaining the functionality of the filter overall. The designed $\mathrm{Fe}^{0}$ $\mathrm{SW}$ filter containing 10 vol. $\%$ of $\mathrm{Fe}^{0}$ is affordable and applicable for the water conditions generally encountered in scattered villages and pre-urban areas in developing countries. This technology is easily adaptable to many kinds of off-site treatment situations, including farms, health centers, hotels, restaurants, and rural schools. Beside $\mathrm{Fe}^{0}$, no chemicals must be used, therefore maintenance is easy.

The results indicate a clear advancement in designing $\mathrm{Fe}^{0}$-based household water units by rationally combining $\mathrm{BSF}$ and $\mathrm{Fe}^{0} /$ sand filters (Ullah et al. 2020, Yang et al. 2020). By using a comparable volumetric $\mathrm{Fe}^{0} / \mathrm{SW}$ ratio but a different $\mathrm{Fe}^{0} \mathrm{SW}$ grade than Bradley et al. (2011), a system still depicting acceptable permeability after one year was obtained. The designed system was able to convert polluted well water containing nitrate, particles, and 
microbes into clean drinking water according to WHO standards. The results of this study suggest that $\mathrm{Fe}^{0} \mathrm{SW}$ filters are very affordable as only small amount of affordable SW (300 g) is required to provide each day $200 \mathrm{~L}$ of clean water over one year.

Considering that the duration of effective decontamination of $\mathrm{Fe}^{0}$-based systems depends on both, the water composition and the nature of used $\mathrm{Fe}^{0}$, the achieved results are only qualitative. The presented results call for further systematic research, which can start by duplicating the experiments reported herein with the seven grades of $\mathrm{Fe}^{0} \mathrm{SW}$ from the same supplier. Another field for future research is the characterization of the effects of typical water constituents on the efficiency of $\mathrm{Fe}^{0} \mathrm{SW}$ filters to eliminate pollutants. Relevant parameters include the presence of $\mathrm{Cl}^{-}, \mathrm{HCO}_{3}{ }^{-}$, humic substances, $\mathrm{PO}_{4}{ }^{3-}$, and $\mathrm{SO}_{4}{ }^{2-}$. Filter containers can be locally designed and constructed.

Providing a chemistry- and electricity-free filter barrier against waterborne diseases by contaminants based on SW filtration appears possible for hundreds of millions of people. Up scaling the presented design for larger communities is one of the next steps. There is a real chance to achieve the US SDGs by implementing $\mathrm{Fe}^{0}$ filters everywhere (Nanseu-Njiki et al. 2019, Yang et al. 2020, Huang et al. 2021b). Strategies for the rapid dissemination of such household and small community $\mathrm{Fe}^{0}$-based filter designs have already been developed and presented in the literature (Ngai et al. 2007; Banerji and Chaudhari 2017). 


\section{A. References:}

Abbas Y., Majeed S., Ali S., Badaruddin-Ahmad H., Akhtar N., Yokota H. (2018): Design of gravel-sand filter for arsenic removal: A case study of Muzaffargarh district in Pakistan. Water Environ. Res. 90, 2106-2113.

Abdel Muslim M., Ali Hammoud Z. (2014): Removal of methylene blue from aqueous solution by using iron filings waste material in batch and continuous experiments. Journal of Babylon University Engineering Sciences 22 (1), 11 pages. DOI:

Ahmed J.U., Tinne W.S., Al-Amin M., Rahanaz M. (2018): Social innovation and SONO filter for drinking water. Soc. Bus. Rev. 13:15-26.

Ako, A., G. Eyong, and G. Nkeng. (2009): Water resources management and integrated water resources management in Cameroon. Water Resources Management 24 (5):871-88. doi:10.1007/ s11269-009-9476-4. DOI: 10.1007/s11269-009-9476-4

Ako Andrew Ako, Jun Shimada, Gloria Takem, FantongWilson. (2010): Access to Potable Water and Sanitation in Cameroon within the Context of Millennium Development Goals (MDGs). Journal of Water Science and Technology-WST/ 61.5/ 2010.1317-1338. DOI: $10.2166 /$ wst.2010.836

Ali, I. (2014): Water treatment by adsorption columns: Evaluation at ground level. Sep. Purif. Rev. 43, 175-205; DOI: 10.1080/15422119.2012.748671

Antia, D.D.J. (2015a): Desalination of groundwater and impoundments using nano-zero valent iron, Fe0. Meteor. Hydrol. Water Manag. 3, 21-38. DOI: 10.26491/mhwm/42201

Antia, D.D.J. (2015b): Desalination of water using ZVI, Fe0. Water 7, 3671-3831. DOI: 10.3390/w7073671

Antia, D.D.J. (2016): ZVI (Fe0) Desalination: Stability of product water. Resources 5, 15. DOI: $10.3390 /$ resources 5010015

Antia D.D.J. (2017): Provision of Desalinated Irrigation Water by the Desalination of Groundwater within a Saline Aquifer. Hydrology 4: 45; DOI:10.3390/hydrology4010001.

Antia D.D.J. (2020): Water treatment and desalination using the eco-materials n-Fe0 (ZVI), n$\mathrm{Fe} 3 \mathrm{O} 4, \mathrm{n}-\mathrm{FexOyHz}\left[\mathrm{mH}_{2} \mathrm{O}\right]$, and n-Fex[Cation]nOyHz[Anion]m $\left[\mathrm{rH}_{2} \mathrm{O}\right]$. In Handbook of Nanomaterials and Nanocomposites for Energy and Environmental Applications, O.V. Kharissova et al. (eds.), Springer Nature Switzerland AG, .

Anderson W. (1883): The Antwerp Waterworks. Minutes of the Proceedings of the Institution of Civil Engineers 72, 24-44. DOI: 10.1680/imotp.1883.21751 
Anderson W. (1884): The purification of water by means of iron on the large scale. Journal of the Society of Arts 32, 963-964.

Anderson W. (1885): The purification of water by means of iron on the large scale. Minutes of the Proceedings of the Institution of Civil Engineers 81, 279-284.

Anderson W. (1886): On the purification of water by agitation with iron and by sand filtration. Journal of the Society for Arts 35 (1775), 29-38.

Anderson W. (1889): The revolving purifier: An apparatus which effects purification of river water and sewage effluent. In the 1885 Anderson Patent.

Asaah, VA., A.F. Abimbola and C.E. Suh, (2006): Heavy metal concentration and distribution in surface soils of the Bassa Industrial Zone 1 Douala Cameroon. Arab. J. Sc. Eng., 31(2A): 147-158. http://www.scopus.com/inward/record.url?eid=2-s2.033846458638\&partnerID=MN8TOARS EID: 2-s2.0-33846458638

Attia A.A., Girgis B.S., Fathy N.A. (2008): Removal of methylene blue by carbons derived from peach stones by H3PO4 activation: Batch and column studies. Dyes and Pigments 76, 282-289.

Avom J., Ketcha J., Noubactep C., Germain P. (1997): Adsorption of methylene blue from an aqueous solution onto activated carbons from palm-tree cobs. Carbon 35, 365-369.

Bache, R.M. (1891): Possible sterilization of city water. Proc. Am. Phil. Soc. 1891, 29, 2639. https://www.jstor.org/stable/983016

Baker, M.N. (1934): Sketch of the history of water treatment. J. Am. Water Works Assoc. 26, 902-938. https://www.jstor.org/stable/41226050

Banerji, T.; Chaudhari, S. (2017): A cost-effective technology for arsenic removal: Case study of zerovalent iron-based iit bombay arsenic filter in west bengal. In Water and Sanitation in the New Millennium; Nath, K., Sharma, V., Eds.; Springer: New Delhi, India, 2017. DOI: 10.1007/978-81-322-3745-7_11

Barker N.W., Linge H.G. (1981): Methylene blue dye adsorption on sulphide minerals Relevance to surface area measurement. Hydrometallurgy 6, 311-326.

Bartzas G., Komnitsas K. (2010): Solid phase studies and geochemical modelling of low-cost permeable reactive barriers. J. Hazard. Mater. 183, 301-308.

Beverskog B., Puigdomenech I. (1996): Revised Pourbaix diagrams for iron at $25-300{ }^{\circ} \mathrm{C}$. Corros. Sci. 38, 2121-2135.

Bi E., Devlin J.F., Huang B. (2009): Effects of mixing granular iron with sand on the kinetics of trichloroethylene reduction. Ground Water Monit. Remed. 29, 56-62. DOI: $10.1111 / j .1745-6592.2009 .01234 . x$ 
Bischof G. (1873): The purification of water: Embracing the action of spongy iron on impure water. Bell and Bain, Glasgow, 1873, 19 pp.

Bischof, G. (1877): On putrescent organic matter in potable water. Proc. R. Soc. Lond. 1877, 26, 258-261. https://doi.org/10.1098/rspl.1877.0023

Bischof, G. (1878): On putrescent organic matter in potable water II. Proc. R. Soc. Lond. 1878, 27, 152-156. https://doi.org/10.1098/rspl.1878.0041

Bojic A., Purenovic M., Kocic B., Perovic J., Ursic-Jankovic J., Bojic D. (2001): The inactivation of Escherichia coli by microalloyed aluminium based composite. Facta Universitatis 2 , $115-124$. https://pdfs.semanticscholar.org/615b/1269c58533ac9877cdf466c712983f6dcf2e.pdf

Bojic A., Purenovic M., Bojic D. (2004): Removal of chromium (VI) from water by microalloyed aluminium based composite in flow conditions. Water SA 30 (3), 353-359. DOI: $10.4314 /$ wsa.v30i3.5084

Bojic A.Lj., Bojic D., Andjelkovic T. (2009): Removal of $\mathrm{Cu} 2+$ and $\mathrm{Zn} 2+$ from model wastewaters by spontaneous reduction-coagulation process in flow conditions. J. Hazard. Mater. 168, 813-819. DOI: 10.1016/j.jhazmat.2009.02.096

Bojic A.Lj., Purenovic M., Bojic D., Andjelkovic T. (2007): Dehalogenation of trihalomethanes by a micro-alloyed aluminium composite under flow conditions. Water SA $\quad 33 \quad(2), \quad 297-304 . \quad$ http://www.wrc.org.za/wpcontent/uploads/mdocs/WaterSA_2007_02_2071.pdf

Bradley I., Straub A., Maraccini P., Markazi S., Nguyen T.H. (2011): Iron oxide amended biosand filters for virus removal. Water Res. 45, 4501-4510. DOI: 10.1016/j.watres.2011.05.045

Bretzler A.M. (2018): Geogenic arsenic in groundwater of Burkina Faso. PhD Dissertation, Faculty of Science of the University of Neuchâtel, Switzerland.

Bretzler A., Nikiema J., Lalanne F. Hoffmann L., Biswakarma J., Siebenaller L., Demange D., Schirmer M., Hug S.J. (2020): Arsenic removal with zero-valent iron filters in Burkina Faso: Field and laboratory insights. Sci. Tot. Environ. 737, 139466.

Btatkeu K.B.D., Miyajima K., Noubactep C., Caré S. (2013): Testing the suitability of metallic iron for environmental remediation: Discoloration of methylene blue in column studies, Chem. Eng. J. 215-216, 959-968. DOI: 10.1016/j.cej.2012.11.072

Btatkeu-K., B.D.; Olvera-Vargas, H.; Tchatchueng, J.B.; Noubactep, C.; Caré, S. (2014a): Determining the optimum $\mathrm{Fe}^{0}$ ratio for sustainable granular $\mathrm{Fe}^{0} /$ sand water filters. Chem. Eng. J. 2014, 247, 265-274. DOI: 10.1016/j.cej.2014.03.008 
Btatkeu-K., B.D.; Olvera-Vargas, H.; Tchatchueng, J.B.; Noubactep, C.; Caré, S. (2014b): Characterizing the impact of $\mathrm{MnO} 2$ on the efficiency of $\mathrm{Fe}^{0}$-based filtration systems. Chem. Eng. J. 2014, 250, 416-422. DOI: 10.1016/j.cej.2014.04.059

Btatkeu-K B.D., Tchatchueng J.B., Noubactep C. Caré S. (2016): Designing metallic iron based water filters: Light from methylene blue discoloration. J. Environ. Manage. 166, $567-573$.

Cao V., Yang H., Ndé-Tchoupé A.I., Hu R., Gwenzi W., Noubactep C. (2020): Tracing the scientific history of $\mathrm{Fe}^{0}$-based environmental remediation prior to the advent of permeable reactive barriers. Processes 8, 977.

Cao V., Alyoussef G., Gatcha-Bandjun N., Gwenzi W., Noubactep C. (2021a): Characterizing the impact of $\mathrm{MnO}_{2}$ addition on the efficiency of $\mathrm{Fe}^{0} / \mathrm{H}_{2} \mathrm{O}$ systems. Sci. Rep. 11, 9814.

Cao V., Alyoussef G., Gatcha-Bandjun N., Gwenzi W., Noubactep C. (2021b): The key role of contact time in elucidating the mechanism of enhanced decontamination by $\mathrm{Fe}^{0} / \mathrm{MnO}_{2} /$ sand systems. Sci. Rep. 11, 12069.

Cao V., Alyoussef G., Gatcha-Bandjun N., Gwenzi W., Noubactep C. (2021c): The suitability of methylene blue discoloration ( $\mathrm{MB}$ method) to investigate the $\mathrm{Fe}^{0} / \mathrm{MnO}_{2}$ system. Processes 9, 548.

Cao V., Ndé-Tchoupé A.I., Hu R., Gwenzi W., Noubactep C. (2021d): The mechanism of contaminant removal in $\mathrm{Fe}(0) / \mathrm{H}_{2} \mathrm{O}$ systems: The burden of a poor literature review. Chemosphere 280, 130614.

Campos L. (2002): Modelling and simulation of the biological and physical processes of slow sand filtration. PhD Dissertation, University of London, UK.

Casentini B., Falcione F.T., Amalfitano S., Fazi S., Rossetti S. (2016): Arsenic removal by discontinuous ZVI two steps system for drinking water production at household scale. Water Res. 106, 135-145.

Caré S., Nguyen Q.T., L'Hostis V., Berthaud Y. (2008): Mechanical properties of the rust layer induced by impressed current method in reinforced mortar. Cement Concrete Res. 38, 1079-1091.

Caré S., Crane R., Calabrò P.S., Ghauch A., Temgoua E., Noubactep C. (2013): Modeling the permeability loss of metallic iron water filtration systems. CLEAN - Soil, Air, Water 41 , $275-282$. https://www.researchgate.net/publication/257764154_Modelling_the_permeability_loss _of_metallic_iron_water_filtration_systems 
Chaudhari S., Banerji T., Kumar P.R. (2014): Domestic and community-scale arsenic removal technologies suitable for developing countries. In: Ahuja, S. (Ed.), Water Reclamation and Sustainability. Elsevier, pp. 155-182. DOI: 10.1016/B978-0-12-411645-0.00007-9

Chen Q., Fan G., Na W., Liu J., Cui J., Li H. (2019): Past, present, and future of groundwater remediation research: A scientometric analysis. Int. J. Environ. Res. Public Health 16, 3975 .

Clasen T., Bartram J., Colford J., Luby S., Quick R., Sobsey M. (2009): Comment on "Household water treatment in poor populations: Is there enough evidence for scaling up now?”. Environ. Sci. Technol. 43 (14), 5542-5544.

Crampon, M.; Joulian, C.; Ollivier, P.; Charron, M.; Hellal, J. (2019): Shift in natural groundwater bacterial community structure due to zero-valent iron nanoparticles (nZVI). Front. Microbiol. 2019, 10, 533. DOI: 10.3389/fmicb.2019.00533

CRC CARE (2016), Guidance document: A framework for selecting, designing and implementing a permeable reactive barrier system, CRC CARE Technical Report no. 25, CRC for Contamination Assessment and Remediation of the Environment, Newcastle, Australia.

Devonshire E. (1890): The purification of water by means of metallic iron. J. Frankl. Inst. 129, 449-461. DOI: 10.1016/0016-0032(90)90189-P

Diao, M.; Yao, M. (2009): Use of zero-valent iron nanoparticles in inactivating microbes. Water Res. 2009, 43, 5243-5251. DOI: 10.1016/j.watres.2009.08.051

Domga R., Togue-Kamga F., Noubactep C., Tchatchueng J.B. (2015): Discussing porosity loss of $\mathrm{Fe}^{0}$ packed water filters at ground level. Chem. Eng. J. 263, 127-134. DOI: 10.1016/j.cej.2014.10.105

Erickson A.J., Gulliver J.S., Weiss P.T. (2007): Enhanced sand filtration for storm water phosphorus removal. J. Environ. Eng. 133, 485-497. DOI: 10.1061/(asce)07339372(2007)133:5(485)

Erickson A.J., Gulliver J.S., Weiss P.T. (2012): Capturing phosphates with iron enhanced sand filtration. Water Res. 46, 3032-3042.

Erickson A.J., Gulliver J.S., Weiss P.T. (2017): Phosphate removal from agricultural tile drainage with iron enhanced sand. Water 9, 672. DOI: 10.3390/w9090672

Etmannski, T.R., Darton, R.C., (2014): A methodology for the sustainability assessment of arsenic mitigation technology for drinking water. Sci. Total Environ. 488 - 489, 505511. 
Etmannski T.R. (2014): Accounting for sustainability in Bengal: Examining arsenic mitigation technologies using process analysis method. PhD thesis, University of Oxford.

Fonjong L., Fokum V. (2017): Water Crisis and Options for Effective Water Provision in Urban and Peri-Urban Areas in Cameroon, PP 1521-0723 ISSN: 0894-1920 DOI: $10.1080 / 08941920.2016 .1273414$

Fortune, W.B.; Mellon, M.G., (1938): Determination of iron with o-phenanthroline. Ind. Eng. Chem. Anal. Ed. 1938, 10, 60-64. DOI: 10.1021/ac50118a004

Frost R.L., Xi Y., He H. (2010): Synthesis, characterization of palygorskite supported zerovalent iron and its application for methylene blue adsorption. J. Colloid Interface Sci. $341,153-161$.

Gatcha-Bandjun N., Noubactep C., Loura Mbenguela B. (2017): Mitigation of contamination in effluents by metallic iron: The role of iron corrosion products. Environmental Technology \& Innovation 8, 71-83. DOI: 10.1016/j.eti.2017.05.002

George D., Ahammed A.M. (2019): Effect of zero-valent iron amendment on the performance of biosand filters. Water Supply 19, 1612-1618. DOI: 10.2166/ws.2019.032

Ghauch, A. (2015): Iron-based metallic systems: An excellent choice for sustainable water treatment. Freib. Online Geosci. 2015, 32, 1-80. ()

Gheju M. (2011): Hexavalent chromium reduction with zero-valent iron (ZVI) in aquatic systems. Water Air Soil Pollut. 222, 103-148.

Gheju M. (2018): Progress in understanding the mechanism of $\mathrm{Cr}^{\mathrm{VI}}$ Removal in $\mathrm{Fe} 0$-based filtration systems. Water 10, 651, doi:10.3390/w10050651.

Gillham R.W. (2008): Development of the granular iron permeable reactive barrier technology (good science or good fortune). In "Advances in environmental geotechnics: proceedings of the International Symposium on Geoenvironmental Engineering in Hangzhou, China, September 8-10, 2007"; Y. Chen, X. Tang, L. Zhan (Eds); Springer Berlin/London, pp. 5-15.

Gleick P.H. (2000): A look at twenty-first century water resources development. Water Int. 25, 127-138. DOI: 10.1080/02508060008686804

Gottinger A.M., McMartin D.W., Wild D.J., Moldovan B. (2013): Integration of zero valent iron sand beds into biological treatment systems for uranium removal from drinking water wells in rural Canada. Can. J. Civ. Eng. 40, 945-950. DOI: 10.1139/cjce-20120512 
Groysman A. (2010): Corrosion for Everybody. Springer Dordrecht, Heidelberg, London, New York.

Guan X., Sun Y., Qin H., Li J., Lo I.M.C., He D., Dong H. (2015): The limitations of applying zero-valent iron technology in contaminants sequestration and the corresponding countermeasures: The development in zero-valent iron technology in the last two decades (1994-2014). Water Res. 75, 224-248. DOI: 10.1016/j.watres.2015.02.034

Gwenzi W., Chaukura N., Noubactep C., Mukome F.N.D. (2017): Biochar-based water treatment systems as a potential low-cost and sustainable technology for clean water provision. J. Environ. Manage. 197, 732-749. DOI: 10.1016/j.jenvman.2017.03.087

Haig S.J., Collins G., Davies R.L., Dorea C.C., Quince C. (2011): Biological aspects of slow sand filtration: past, present and future. Water Sci. Technol., Water Supply 11, 468472. DOI: $10.2166 /$ ws. 2011.076

Hatton, F. (1881): On the oxidation of organic matter in water by filtration through various media; and on the reduction of nitrates by sewage, spongy iron, and other agents. J. Chem. Soc. Trans. 1881, 39, 258-276.

He F., Gong L., Fan D., Tratnyek P.G., Lowry G.V. (2020): Quantifying the efficiency and selectivity of organohalide dechlorination by zerovalent iron. Environ. Sci.: Processes Impacts 22, 528.

Heimann, S.; Ndé-Tchoupé, A.I.; Hu, R.; Licha, T.; Noubactep, C. (2018): Investigating the suitability of $\mathrm{Fe}^{0}$ packed-beds for water defluoridation. Chemosphere 2018, 209, 578587. DOI: 10.1016/j.chemosphere.2018.06.088

Henderson A.D., Demond A.H. (2007): Long-term performance of zero-valent iron permeable reactive barriers: a critical review. Environ. Eng. Sci. 24, 401-423. DOI: 10.1089/ees.2006.0071

Hering J.G., Maag S., Schnoor J.L. (2016): A call for synthesis of water research to achieve the sustainable development goals by 2030. Environ. Sci. Technol. 50, 6122-6123. DOI: $10.1021 /$ acs.est.6b02598

Heron G., Crouzet C., Bourg C.M.A., Christensen H.T. (1994): Speciation of Fe(II) and $\mathrm{Fe}(\mathrm{III})$ in contamninated aquifer sediments using chemical extraction techniques. Environ. Sci. Technol. 28, 1698-1705.

Hildebrant B. (2018): Characterizing the reactivity of commercial steel wool for water treatment. Freiberg Online Geosci. 53, 76 pp. DOI: 10.13140/RG.2.2.15181.90083 
Hildebrant B., Ndé-Tchoupé A.I., Lufingo M., Licha T., Noubactep C. (2020): Steel wool for water treatment: Intrinsic reactivity and defluoridation efficiency. Processes 8, 265. DOI: $10.3390 /$ pr8030265

Howe K.J., Hand D.W., Crittenden J.C., Trussell R.R., Tchobanoglous G. (2012): Principles of Water Treatment. John Wiley \& Sons, Inc., Hoboken, New Jersey, 674 pp. https://www.academia.edu/39985730/Principles_of_Water_Treatment_Howe_et_al._20 12

Hope R., Ballon P. (2019): Global water policy and local payment choices in rural Africa. npj Clean Water 2, 21.

Hope R., Thomson P., Koehler J., Foster T. (2020): Rethinking the economics of rural water in Africa. Oxford Rev. Econ. Pol. 36, 171-190.

Hu, R.; Gwenzi, G.; Sipowo, R.; Noubactep, C. (2019a): Water treatment using metallic iron: A tutorial review. Processes 2019, 7, 622. DOI: 10.3390/pr7090622

Hu R., Cui X., Xiao M., Qiu P., Lufingo M., Gwenzi W., Noubactep C. (2019b): Characterizing the suitability of granular $\mathrm{Fe}^{0}$ for the water treatment industry. Processes 7, 652. DOI: $10.3390 / \mathrm{pr} 7100652$

$\mathrm{Hu}, \mathrm{R}$; Noubactep, C. (2019c): Redirecting research on $\mathrm{Fe}^{0}$ for environmental remediation: The search for synergy. Int. J. Environ. Res. Public Health 2019, 16, 4465. DOI: 10.3390/ijerph16224465

Hu R., Yang H., Tao R., Cui X., Xiao M., Konadu-Amoah B., Cao V., Lufingo M., SoppaSangue N.P., Ndé-Tchoupé A.I., Gatcha-Bandjun N., Sipowo-Tala V.R., Gwenzi W., Noubactep C. (2020): Metallic iron for environmental remediation: Starting an overdue progress in knowledge. Water 12, 641. DOI: 10.3390/w12030641.

Hu R., Cui X., Xiao M., Gwenzi W., Noubactep C. (2021a): Characterizing the impact of pyrite addition on the efficiency of $\mathrm{Fe}^{0} / \mathrm{H}_{2} \mathrm{O}$ systems. Sci. Rep. 11, 2326.

Hu R., Ndé-Tchoupé A.I., Cao V., Gwenzi W., Noubactep C. (2021b): Metallic iron for environmental remediation: The fallacy of the electron efficiency concept. Frontiers Environ. Chem. 2, 677813.

Hu, Y.; Wang, J.; Sun, H.; Wang, S.; Liao, X.; Wang, J.; An, T. (2019): Roles of extracellular polymeric substances in the bactericidal effect of nanoscale zero-valent iron: Trade-offs between physical disruption and oxidative damage. Environ. Sci. Nano 2019, 6, 20612073. DOI: 10.1039/C9EN00354A

Huang Z., Nya E.L., Rahman M.A., Mwamila T.B., Cao V., Gwenzi W., Noubactep C. (2021a): Integrated water resource management: Rethinking the contribution of rainwater harvesting. Sustainability 13, 8338. 
Huang Z., Nya E.L., Cao V., Gwenzi W., Rahman M.A., Noubactep C. (2021b): Universal access to safe drinking water: Escaping the traps of non-frugal technologies. Sustainability 13,9645 .

Hussam A., Munir A.K.M. (2007): A simple and effective arsenic filter based on composite iron matrix: Development and deployment studies for groundwater of Bangladesh. J. Environ. Sci. Health A 42, 1869-1878. DOI: 10.1080/10934520701567122

Hussam, A. (2009): Contending with a Development Disaster: SONO Filters Remove Arsenic from Well Water in Bangladesh. Innovations 2009, 4, 89-102. DOI: 10.1162/itgg.2009.4.3.89

Ingram, D.T.; Callahan, M.T.; Ferguson, S.; Hoover, D.G.; Shelton, D.R.; Millner, P.D.; Camp, M.J.; Patel, J.R.; Kniel, K.E.; Sharma, M. (2011): Use of zero-valent iron biosand filters to reduce E. coli O157:H12 in irrigation water applied to spinach plants in a field setting. J. Appl. Microbiol. 2012, 112, 551-560. DOI: 10.1111/j.13652672.2011.05217.x

ITRC (1999): Interstate Technology Regulatory Council, Regulatory Guidance for Permeable Reactive Barriers Designed to Remediate Chlorinated Solvents.Washington D.C. www.itrcweb.org.

ITRC (2005): Interstate Technology Regulatory Council, Permeable Reactive Barriers: Lessons Learned/New Directions. PRB-4. Washington, D.C. www.itrcweb.org.

ITRC (2011): Interstate Technology Regulatory Council, Permeable reactive barrier: Technology update PRB-5. Washington, D.C. www.itrcweb.org.

James B.R., Rabenhorst M.C., Frigon G.A. (1992): Phosphorus sorption by peat and sand amended with iron oxides or steel wool. Water Environ. Res. 64, 699-705. DOI: 10.2175/WER.64.5.6

Jia, Y.; Aagaard, P.; Breedveld, G.D. (2007): Sorption of triazoles to soil and iron minerals. Chemosphere 2007, 67, 250-258. DOI: 10.1016/j.chemosphere.2006.10.021

Kaplan D.I., Gilmore T.J. (2004): Zero-valent iron removal rates of aqueous Cr(VI) Measured under flow conditions. Water Air Soil Pollut. 155, 21-33.

Kearns J.P. (2016): Biochar adsorbent for control of synthetic organic contaminants in affordable decentralized water treatment. PhD Dissertation, University of Colorado

Khan A.H., Rasul S.B., Munir A.K.M., Habibuddowla M., Alauddin M., Newaz S.S., Hussam A. (2000): Appraisal of a simple arsenic removal method for groundwater of bangladesh. J. Environ. Sci. Health A35, 1021-1041. DOI: $10.1080 / 10934520009377018$ 
Khalil A.M.E., Eljamal O., Saha B.B., Matsunaga N. (2018): Performance of nanoscale zerovalent iron in nitrate reduction from water using a laboratory-scale continuous-flow system. Chemosphere 197, 502-512.

Kim H., Yang H., Kim J. (2014): Standardization of the reducing power of zerovalent iron using iodine. Environ. Lett. 49, 514-523. DOI: 10.1080/10934529.2014.859029

Kim S., Eckart K., Sabet S., Chiu P.C., Sapkota A.R., Handy E.T., East C.L., Kniel K.E., Sharma M. (2021): Escherichia coli reduction in water by zero-valent iron-sand filtration is based on water quality parameters. Water 13, 2702.

Kodikara J., Gunawardana B., Jayaweera M., Sudasinghe M., Manatunge J. (2020): Nitrate removal in potable groundwater by nano zerovalent iron under oxic conditions. Water Practice Technol. 15, 1126-1143.

Kosmulski M. (2016): Isoelectric points and points of zero charge of metal (hydr)oxides: 50 years after Parks' review. Adv. Colloid and Interface Sci. 238, 1-61.

Kowalski K.P., Søgaard E.G. (2014): Implementation of zero-valent iron (ZVI) into drinking water supply - Role of the ZVI and biological processes. Chemosphere 117, 108-114. DOI: 10.1016/j.chemosphere.2014.05.088

Kurth A.-M. (2008): Discoloration of methylene blue by elemental iron - influence of the shaking intensity. Bachelor thesis, Universität Göttingen, 45 pp.

Lackovic J.A., Nikolaidis N.P., Dobbs G.M. (2000): Inorganic arsenic removal by zero-valent iron. Environ. Eng. Sci. 17, 29-39. DOI: 10.1089/ees.2000.17.29

Landis R.L., Gillham R.W., Reardon E.J., Fagan R., Focht R.M., Vogan J.L. (2001): An examination of zero-valent iron sources used in permeable reactive barriers. 3rd International Containment Technology Conference (10-13 June 2001), Florida State $\begin{array}{lllll}\text { University, } & \text { Tallahassee. } & \text { Orlando, } & \text { FL. } & 5\end{array}$ pages. https://www.researchgate.net/publication/268009510_An_Examination_of_Zerovalent_Iron_Sources_used_in_Permeable_Reactive_Barriers

Landolt, D. (2007): Corrosion and Surface Chemistry of Metals, 1st ed.; EPFL Press: Lausanne, Switzerland, 2007; p. 615. DOI:10.5860/choice.45-0897

Lanet P., Deluchat V., Baudu M. (2021): Relevant design parameters for a reactor used in P removal with ZVI-based materials. J. Ind. Eng. Chem., https://doi.org/10.1016/j.jiec.2021.08.005.

Latrach L., Ouazzani N., Hejjaj A., Mahi M:, Masunaga T., Mandi L. (2018): Two-stage vertical flow multi-soil-layering (MSL) technology for efficient removal of coliforms 
and human pathogens from domestic wastewater in rural areas under arid climate. Int. J. Hyg. Environ. Health 22, 64-80.

Lauderdale R.A., Emmons A.H. (1951): A method for decontaminating small volumes of radioactive water. Journal American Water Works Association 43, 327-331. DOI: .

Lazzari L. (2008): "General aspects of corrosion", Chapter 9.1, Vol.V, Encyclopedia of Hydrocarbons, Istituto Enciclopedia Italiana, Rome, Italy.

Lea M. (2008): Biological sand filters: Low-cost bioremediation technique for production of clean drinking water. Current Protocols in Microbiology 1G.1.1-1G.1.28, DOI: 10.1002/9780471729259.mc01g01s9. DOI: 10.1002/9780471729259.mc01g01s9

Lee G., Rho S., Jahng D. (2004): Design considerations for groundwater remediation using reduced metals. Korean J. Chem. Eng. 21, 621-628.

Lee, C.; Kim, J.H.; Lee, W.I.; Nelson, K.L.; Yoon, J.; Sedlak, D.L. (2008): Bactericidal effect of zero-valent iron nanoparticles on escherichia coli. Environ. Sci. Technol. 2008, 42, 4927-4933. DOI: 10.1021/es800408u

Leffmann, H. (1991): The purification of water by metallic iron. In Proceedings of the 11th Annual Meeting of the American Water Works Association, Philadelphia, PA, USA, 14-16 April 1991; pp 163-171.

Lewis A.E. (2010): Review of metal sulphide precipitation. Hydrometallurgy 104, 222-234.

Li S., Ding Y., Wang W., Lei H. (2016): A facile method for determining the Fe(0) content and reactivity of zero valent iron. Anal. Methods 8, 1239-1248. DOI: 10.1039/C5AY02182K

Li Z., Huang D., McDonald L.M. (2017): Heterogeneous selenite reduction by zero valent iron steel wool. Water Sci. Technol. 75, 908-915. DOI: 10.2166/wst.2016.574

Li J., Dou X., Qin H., Sun Y., Yin D., Guan X. (2019): Characterization methods of zerovalent iron for water treatment and remediation. Water Res. 148, 70-85. DOI: 10.1016/j.watres.2018.10.025

Li X., Li Z., Du C., Tian Z., Zhu Q., Li G., Shen Q., Li C., Li J., Li W., Zhao C., Zhang L. (2021): Bibliometric analysis of zerovalent iron particles research for environmental remediation from 2000 to 2019. Environ. Sci. Pollut. Res. 28, 4200-34210.

Liu, X.; Millero, F.J. (1999): The solubility of iron hydroxide in sodium chloride solutions. Geochim. Cosmochim. Acta 1999, 63, 3487-3497. DOI: 10.1016/S00167037(99)00270-7

Liu H., Wang Q., Wang C., Li X.-Z. (2013): Electron efficiency of zero-valent iron for groundwater remediation and wastewater treatment. Chem. Eng. J. 215-216, 90-95. 
Lufingo M., Ndé-Tchoupé A.I., Hu R., Njau K.N., Noubactep C. (2019): A novel and facile method to characterize the suitability of metallic iron for water treatment. Water 11, 2465. DOI: $10.3390 / \mathrm{w} 11122465$

Lufingo M. (2019): Investigation of Metallic Iron for Water Defluoridation. Master's Thesis, Nelson Mandela African Institution of Science and Technology, Arusha, Tanzania, 2019 .

Luo, P.; Bailey, E.H.; Mooney, S.J. (2013): Quantification of changes in zero valent iron morphology using X-ray computed tomography. J. Environ. Sci. 2013, 25, 2344-2351. DOI: 10.1016/S1001-0742(12)60237-X

Mackenzie, P.D.; Horney, D.P.; Sivavec, T.M. (1999): Mineral precipitation and porosity losses in granular iron columns. J. Hazard. Mater. 1999, 68, 1-17. DOI: 10.1016/S03043894(99)00029-1

Mafany, G.T., W.T. Fantong and G.E. Nkeng (2006): Groundwater quality in Cameroon and its vulnerability to pollution. DOI: 10.1201/9780203963548.ch4 In Y. Xu and B. Usher (Eds.): Ground Water Pollution in Africa. Taylor and Francis (Balkema), The Netherlands, pp: 47-55. DOI: https://doi.org/10.1201/9780203963548

Marik, C.M.; Anderson-Coughlin, B.; Gartley, S.; Craighead, S.; Kniel, K.E. (2019): The efficacy of zero valent iron-sand filtration on the reduction of Escherichia coli and Listeria monocytogenes in surface water for use in irrigation. Environ. Res. 2019, 173, 33-39. DOI: 10.1016/j.envres.2019.02.028

Marwa J., Lufingo M., Noubactep C., Machunda R. (2018): Defeating fluorosis in the East African Rift Valley: Transforming the Kilimanjaro into a rainwater harvesting park. Sustainability 10, 4194. DOI: 10.3390/su10114194

McGeough K.L., Kalin R.M., Myles P. (2007): Carbon disulfide removal by zero valent iron. Environ. Sci. Technol. 41, 4607-4612.

McGuire M.M., Carlson D.L., Vikesland P.J., Kohn T., Grenier A.C., Langley L.A., Roberts A.L., Fairbrother D.H. (2003): Applications of surface analysis in the environmental sciences: dehalogenation of chlorocarbons with zero-valent iron and iron-containing mineral surfaces. Anal. Chim. Acta 496 (1-2), 301-313.

MINPLADAT (Ministry of Planning, Programming and Regional Development) (2006):

Progress Report on the Implementation of the Poverty Reduction Strategy. Paper as of 31 Dec 2005. DOI:

https://pdfs.semanticscholar.org/01c4/e995ba73dd6c27e1fb249780a4046769e9ce.pdf 
Mitchell G., Poole P., Segrove H.D. (1955): Adsorption of methylene blue by high-silica sands. Nature 176, 1025-1026. DOI: 10.1038/1761025a0

Miyajima K. (2012): Optimizing the design of metallic iron filters for water treatment. Freiberg Online Geosci. 32, 1-60. DOI: https://tu-freiberg.de/geo/fog- Volume 32 (2012)

Miyajima K., Noubactep C. (2012): Effects of mixing granular iron with sand on the efficiency of methylene blue discoloration. Chem. Eng. J. 200-202, 433-438. DOI: 10.1016/j.cej.2012.06.069

Miyajima K., Noubactep C. (2013): Impact of $\mathrm{Fe}^{0}$ amendment on methylene blue discoloration by sand columns. Chem. Eng. J. 217, 310-319. DOI: 10.1016/j.cej.2012.11.128

Miyajima K., Noubactep C. (2015): Characterizing the impact of sand addition on the efficiency of granular iron for water treatment. Chem. Eng. J. 262, 891-896.

Moraci N., Lelo D., Bilardi S., Calabrò P.S. (2016): Modelling long-term hydraulic conductivity behaviour of zero valent iron column tests for permeable reactive barrier design. Canadian Geotech. J. 53, 946-961. DOI: 10.1139/cgj-2015-0453

Mueller B. (2021): Results of the first improvement step regarding removal efficiency of kanchan arsenic filters in the lowlands of Nepal - A case study. Water 13, 1765.

Mueller B., Dangol B., Ngai T.K.K., Hug S.J. (2021): Kanchan arsenic filters in the lowlands of Nepal: mode of operation, arsenic removal, and future improvements. Environ. Geochem. Health 43, 375-389, https://doi.org/10.1007/s10653-020-00718-9.

Murphy, H.M.; McBean, E.A.; Farahbakhsh, K. (2010): Nitrification, denitrification and ammonification in point-of-use biosand filters in rural Cambodia. J. Water Health 2010, 8, 803-817. DOI: $10.2166 /$ wh.2010.163

Mwakabona H.T., Ndé-Tchoupé A.I., Njau K.N., Noubactep C., Wydra K.D. (2017): Metallic iron for safe drinking water provision: Considering a lost knowledge. Water Res. 117, 127-142. DOI: 10.1016/j.watres.2017.03.001

Naidu R. Birke V. (2015): Permeable Reactive Barrier: Sustainable Groundwater Remediation. $\quad$ CRC Press, ISBN: 978-1-4822-2447-4, p. 333. DOI https://doi.org/10.1201/9781351228886.

Nakhla, G.; Farooq, S. (2003): Simultaneous nitrification-denitrification in slow sand filters. J. Hazard. Mater. 2003, 96, 291-303. DOI: 10.1016/S0304-3894(02)00219-4 
Nanseu-Njiki C.P., Gwenzi W., Pengou M., Rahman M.A., Noubactep C. (2019): $\mathrm{Fe}^{0} / \mathrm{H}_{2} \mathrm{O}$ filtration systems for decentralized safe drinking water: Where to from here? Water 11, 429. DOI: $10.3390 /$ w1 1030429

Naseri E., Ndé-Tchoupé A.I., Mwakabona H.T., Nanseu-Njiki C.P., Noubactep C., Njau K.N., Wydra K.D. (2017): Making $\mathrm{Fe}^{0}$-based filters a universal solution for safe drinking water provision. Sustainability 9, 1224. DOI: 10.3390/su9071224

Ndé-Tchoupé A.I., Crane R.A., Hezron T. Mwakabona, Noubactep C., Njau K.N. (2015): Technologies for decentralized fluoride removal: Testing metallic iron based filters. Water 7, 6750-6774. DOI: 10.3390/w7126657

Ndé-Tchoupé A.I, Makota S., Nassi A., Hu R., Noubactep C. (2018): The suitability of pozzolan as admixing aggregate for $\mathrm{Fe}^{0}$-based filters. Water 10, 417. DOI: 10.3390/w10040417

Ndé-Tchoupé, A.I. (2019): Design and Construction of Fe0-Based Filters for Households. Ph.D. Thesis, University of Douala, Douala, Cameroon, 2019. (In French).

Nesic S. (2007): Key issues related to modelling of internal corrosion of oil and gas pipelines - A review. Corros. Sci. 49, 4308-4338.

Neumann A., Kaegi R., Voegelin A., Hussam A., Munir A.K.M., Hug S.J. (2013): Arsenic removal with composite iron matrix filters in Bangladesh: A field and laboratory study. Environ. Sci. Technol. 47, 4544-4554. DOI: 10.1021/es305176x

Ngai T.K.K., Murcott S., Shrestha R.R., Dangol B., Maharjan M. (2006): Development and dissemination of Kanchan ${ }^{\mathrm{TM}}$ Arsenic Filter in rural Nepal, Water Sci. Technol. Water Supply 6, 137-146. DOI: 10.2166/ws.2006.807

Ngai T.K.K., Shrestha R.R., Dangol B., Maharjan M., Murcott S.E. (2007): Design for sustainable development - Household drinking water filter for arsenic and pathogen treatment in Nepal. J. Environ. Sci. Health A42, 1879-1888. DOI: 10.1080/10934520701567148

Njaramba L.K., Park J.-B., Lee C.-S., Nzioka A.M., Kim Y.-J. (2021): Permeable reactive barriers with zero-valent iron and pumice for remediation of groundwater contaminated with multiple heavy metals. Environ. Eng. Sci. 38, 245-255.

Notter, J.L. (1878): The purification of water by filtration. Br. Med. J. 1878, Oct. 12, 556557. DOI: $10.1136 / \mathrm{bmj} .2 .928 .556$

Noubactep C., Fall M., Meinrath G., Merkel B. (2004): A simple method to select zero valent iron material for groundwater remediation. paper presented at the Quebec 2004, $57^{\mathrm{TH}}$ 
Canadian Geotechnical Conference, $5^{\mathrm{TH}}$ Joint CGS/IAH-CNC Conference, Session 1A, pp. 6-13.

Noubactep C., Meinrath G., Dietrich P., Sauter M., Merkel B. (2005): Testing the suitability of zerovalent iron materials for reactive Walls. Environ. Chem. 2, 71-76. DOI: 10.1071/EN04014

Noubactep C., Schöner A., Meinrath G. (2006): Mechanism of uranium (VI) fixation by elemental iron. J. Hazard Mater. 132, 202-212.

Noubactep C. (2007): Processes of contaminant removal in " $\mathrm{Fe}^{0}-\mathrm{H}_{2} \mathrm{O}$ " systems revisited. The importance of co-precipitation. Open Environ. Sci. 1, 9-13.

Noubactep C. (2008): A critical review on the mechanism of contaminant removal in $\mathrm{Fe}^{0}$ $\mathrm{H}_{2} \mathrm{O}$ systems. Environ. Technol. 29, 909-920.

Noubactep C., Woafo P. (2008): Elemental iron $\left(\mathrm{Fe}^{0}\right)$ for better drinking water in rural areas of developing countries. In Merkel B.J., Hasche-Berger A. (Eds.) Uranium in the Environment. Springer, Berlin, Heidelberg; 121-130. DOI: 10.1007/978-3-540-87746$2 \_18$

Noubactep C., Schöner A., Woafo P. (2009): Metallic iron filters for universal access to safe drinking water. Clean: Soil Air Water 37, 930-937. DOI: 10.1002/clen.200900114

Noubactep C., Schöner A. (2010a): Metallic iron: dawn of a new era of drinking water treatment research? Fresenius Environ. Bull. 19, 1661-1668. DOI: http://resolver.sub.uni-goettingen.de/purl?gs-1/9028

Noubactep C., Caré S. (2010b): Enhancing sustainability of household water filters by mixing metallic iron with porous materials. Chem. Eng. J. 162, 635-642.

Noubactep C. (2010): Metallic iron for safe drinking water worldwide. Chem. Eng. J. 165, 740-749.

Noubactep C. (2011): Metallic iron for safe drinking water production. Freiberg Online Geosci. 27, 1-38.

Noubactep C., Temgoua E., Rahman M.A. (2012): Designing iron-amended biosand filters for decentralized safe drinking water provision. CLEAN - Soil, Air, Water 40, 798-807. DOI: $10.1002 /$ clen.201100620

Noubactep C. (2015): Metallic iron for environmental remediation: a review of reviews. Water Res. 85, 114-123. DOI: 10.1016/j.watres.2015.08.023

Noubactep C. (2016): Predicting the hydraulic conductivity of metallic iron filters: Modeling gone astray. Water 8, 162. DOI: 10.3390/w8040162 
Noubactep C. (2018): Metallic iron $\left(\mathrm{Fe}^{0}\right)$ provide possible solution to universal safe drinking water provision. J. Water Technol. Treat. Methods. 1(1):102.

Noubactep C. (2020): Metallic Iron for Environmental Remediation: Prospects and Limitations. Chap. 36, A Handbook of Environmental Toxicology: Human Disorders and Ecotoxicology. J.P.F. D’Mello (ed), CAB International, 531-544.

Noubactep C. (2021): Metallic iron for the removal of metals and metalloids from aqueous solutions: An old timer view. Curr. Opin. Environ. Sci. Health 22, 100256.

Noubactep C. (2022): Should the term 'metallic iron' appear in the title of a research paper? Chemosphere 287, 132314.

Nya E.L. (2020): Access to drinking water and sanitation in Nde Division, Cameroon. PhD Dissertation, University of Yaoundé I, 483.

Nya E.L., Mougoué B. (2020): Access to safe drinking water and sanitary risks in the town of Bangangté (West Region of Cameroon). Saudi J. Human. Soc. Sci., doi:10.36348/sjhss.2020.v05i03.007.

Ogata R., Dangol B., Sakamoto M. (2020): Sustainability assessment of long-term, widely used household Kanchan Arsenic Filters in Nepal, J. Environ. Sci. Healtht A 55, 517527.

Ogston F.H. (1885): The purification of water by metallic iron in Mr Anderson's revolving purifiers. Minutes of the Proceedings of the Institution of Civil Engineers 81, 285-294

O’Hannesin S.F., Gillham R.W. (1998): Long-term performance of an in situ "iron wall" for remediation of VOCs. Ground Water 36, 164-170. DOI: 10.1111/j.17456584.1998.tb01077.x

Pembe-Ali Z., Mwamila T.B., Lufingo M., Gwenzi W., Marwa J., Rwiza M.J., Lugodisha I., Qi Q., Noubactep C, Muzuka A.N.N.(2020): Defeating salt intrusion in Unguja Island, Zanzibar (Tanzania) using the Kilimanjaro Concept. Sustainable Development (Submitted)

Phukan M. (2015): Characterizing the $\mathrm{Fe} 0 /$ sand system by the extent of dye discoloration. Freiberg Online Geosci. 40, 1-70.

Phukan M., Noubactep C., Licha T. (2016): Characterizing the ion selective nature of $\mathrm{Fe}^{0}$ based filters using three azo dyes in batch systems. J Environ Chem. Eng. 4, 65-72.

Pilling N. B., Bedworth R.E. (1923): The oxidation of metals at high temperatures. J. Inst.

Metals, 29, 529-591. DOI:

https://www.researchgate.net/publication/265556796_The_Oxidation_of_Metals_in_Hi gh_Temperature 
Purenovic M., Perovic J., Bojic A., Andjelkovic T., Bojic D. (2004): Cu and Cd removal fromwastewater by microalloyed aluminium based composite, Environ. Chem. Lett. 2, 59-63. DOI: 10.1007/s10311-004-0074-7

Qi Q., Marwa J., Mwamila T.B., Gwenzi W., Noubactep C. (2019): Making Rainwater Harvesting a Key Solution for Water Supply: The Universality of the Kilimanjaro Concept. Sustainability 11, 5606. DOI: 10.3390/su11205606

Qin H., Guan X., Bandstra J.Z., Johnson R.L., Tratnyek P.G. (2018): Modeling the kinetics of hydrogen formation by zerovalent iron: effects of sulfidation on micro- and nano-scale particles. Environ. Sci. Technol. 52, 13887-13896.

Reardon J.E. (1995): Anaerobic corrosion of granular iron: Measurement and interpretation of hydrogen evolution rates. Environ. Sci. Technol. 29, 2936-2945.

Reardon E.J. (2005): Zerovalent irons: Styles of corrosion and inorganic control on hydrogen pressure buildup. Environ. Sci. Tchnol. 39, 7311-7317.

Reardon E.J. (2014): Capture and storage of hydrogen gas by zero-valent iron. J. Contam. Hydrol. 157, 117-124.

Richardson J.P., Nicklow J.W. (2002): In situ permeable reactive barriers for groundwater contamination. Soil and Sediment Contamination 11, 241-268. DOI: $10.1080 / 20025891106736$

Santisukkasaem, U.; Das, D.B. (2019): A non-dimensional analysis of permeability loss in zero-valent iron permeable reactive barrier (PRB). Transp. Porous Media 2019, 126, 139-159. DOI: 10.1007/s11242-018-1096-0

Sato N. (2001): Surface oxides affecting metallic corrosion. Corros. Rev. 19, 253-272.

Saywell, L.G.; Cunningham, B.B. (1937): Determination of iron: Colorimetric ophenanthroline method. Ind. Eng. Chem. Anal. Ed. 1937, 9, 67-69. DOI: $10.1021 / \mathrm{ac} 50106 \mathrm{a} 005$

Schirmer M. (2003): RUBIN - Reinigungswände und -barrieren im Netzwerkverbund. Grundwasser 3, 145.

Shannon M.A., Bohn P.W., Elimelech M., Georgiadis J.G., Marinas B.J., Mayes A.M. (2008): Science and technology for water purification in the coming decades. Nature 452, 301310. DOI: $10.1038 /$ nature06599

Shi, C.; Wei, J.; Jin, Y.; Kniel, K.E.; Chiu, P.C.(2012): Removal of viruses and bacteriophages from drinking water using zero-valent iron. Sep. Purif. Technol. 2012, 84, 72-78. DOI: 10.1016/j.seppur.2011.06.036 
Sleiman, N.; Deluchat, V.; Wazne, M.; Mallet, M.; Courtin-Nomade, A.; Kazpard, V.; Baudu, M. (2016): Phosphate removal from aqueous solution using $\mathrm{ZVI} /$ sand bedreactor: Behavior and mechanism. Water Res. 2016, 99, 56-65. DOI: 10.1016/j.watres.2016.04.054

Smith K., Li Z., Chen B., Liang H., Zhang X., Xu R., Li Z., Dai H., Wei C., Liu S. (2017): Comparison of sand-based water filters for point-of-use arsenic removal in China. Chemosphere 168, 155-162.

Stratmann M., Müller J. (1994): The mechanism of the oxygen reduction on rust-covered metal substrates. Corros. Sci. 36, 327-359.

Stefanoni M., Angst U.M., Elsener B. (2018): Electrochemistry and capillary condensation theory reveal the mechanism of corrosion in dense porous media. Sci. Rep. 8, 7407.

Suchel, B., (1988): Les Climats du Cameroun; La répartition des pluies et des régions pluviométriques au Cameroun. Travaux et document de géographie tropicale (C.E.G.CNRS), 5: 1-288.

Sun, H.; Wang, J.; Jiang, Y.; Shen, W.; Jia, F.; Wang, S.; Liao, X.; Zhang, L. (2019): Rapid aerobic inactivation and facile removal of escherichia coli with amorphous zero-valent iron microspheres: Indispensable roles of reactive oxygen species and iron corrosion products. Environ. Sci. Technol. 2019, 53, 3707-3717. DOI: 10.1021/acs.est.8b06499

Tanawa, E., H. B. D. Tchapnga, E. Ngnikam, E. Temgoua, and J. Siakeu. (2002): Habitat and protection of water resources in suburban areas in African cities. Building and Environment 37:269-75. DOI:10.1016/s0360-1323(01)00024-5

Tepong-Tsindé R., Crane R., Noubactep C., Nassi A., Ruppert H. (2015): Testing metallic iron filtration systems for decentralized water treatment at pilot scale. Water 7, 868897. DOI: $10.3390 /$ w7030868

Tepong-Tsindé R., Phukan M., Nassi A., Noubactep C., Ruppert H. (2015): Validating the efficiency of the MB discoloration method for the characterization of $\mathrm{Fe}^{0} / \mathrm{H}_{2} \mathrm{O}$ systems using accelerated corrosion by chloride ions. Chemical Engineering Journal 279, 353 362.

Tepong-Tsindé R., Ndé-Tchoupé A.I., Noubactep C., Nassi A., Ruppert H. (2019): Characterizing a newly designed steel-wool-based household filter for safe drinking water provision: Hydraulic conductivity and efficiency for pathogen removal. Processes 7, 966. DOI: $10.3390 /$ pr7120966 
Togue-Kamga F. (2013): Modelling, numerical simulation and experimental study of iron filters for safe drinking water provision. PhD Dissertation, University of Yaoundé I, Yaounde /Cameroon.

Tomizawa M., Kurosu S., Kobayashi M., Kawase Y. (2016): Zero-valent iron treatment of dark brown colored coffee effluent: Contributions of a core-shell structure to pollutant removals. J. Environ. Manag. 183, 478-487. DOI: https://doi.org/10.1016/j.biopen.2016.06.001.

Tuladhar S., Smith L.S. (2009): SONO filter: An excellent technology for save water in Nepal. SOPHEN 7, 18-24.

Tucker, W.G. (1892): The purification of water by chemical treatment. Science 1892, 20, 3438. DOI: 10.1126/science.ns-20.493.34-a

Tweeddale, W. (1898): Water purification. Trans. Ann. Meet. Kans. Acad. Sci. 1898, 16, 4852. URL: .

Ullah S., Guo X., Luo X., Zhang X., Li Y., Liang Z. (2020): The coupling of sand with ZVI/oxidants achieved proportional and highly efficient removal of arsenic. Front. Environ. Sci. Eng. 14, 94.

UNESCO (2009) Facing the Challenges: The United Nations World Water Report 3. Case studies Volume, UNESCO, Paris.

Van Craenenbroeck W. (1998): Easton \& Anderson and the water supply of Antwerp (Belgium). Ind. Archaeol. Rev. 20, 105-116.

Velimirovic M., Larsson P.-O., Simons Q., Bastiaens L. (2013): Reactivity screening of microscale zerovalent irons and iron sulfides towards different CAHs under standardized experimental conditions. J. Hazard. Mater. 252-253, 204-212.

Villen-Guzman M., Paz-Garcia J.M., Arhoun B., Cerrillo-Gonzalez M.d.M., RodriguezMaroto J.M., Vereda-Alonso C., Gomez-Lahoz C. (2020): Chemical reduction of nitrate by zero-valent iron: shrinking-core versus surface kinetics models. Int. J. Environ. Res. Public Health 17, 1241.

Wakatsuki T., Esumi H., Omura S. (1993): High performance and N, P removable on-site domestic wastewater treatment system by multi-soil-layering method. Water Sci. Technol. 27, 31-40.

Wegelin M (1996): Surface Water Treatment by Roughing Filters; a Design, Construction and Operation Manual. SANDEC Report No. 2/96, Swiss Centre for Development Cooperation in Technology and Management (SKAT), CH - 9000 St. Gallen, Switzerland. DOI https://www.ircwash.org/sites/default/files/Wegelin-1996-Surface.pdf 
Wenk C.B., Kaegi R., Hug S.J. (2014): Factors affecting arsenic and uranium removal with zero-valent iron: laboratory tests with Kanchan-type iron nail filter columns with different groundwaters. Environ. Chem. 11, 547-557. DOI: https://doi.org/10.1071/EN14020

Westerhoff P., James J. (2003): Nitrate removal in zero-valent iron packed columns. Water Res. 37, 1818-1830. DOI: https://doi.org/10.1016/S0043-1354(02)00539-0

WHO (2017): Progress on Drinking Water, Sanitation and Hygiene-2017 Update and SDG Baselines; WHO JMP launch version July 12, 2017; WHO Library Cataloguing-inPublication Data; WHO: Geneva, Switzerland, 2017; DOI:10.1007/s12686-011-9397-4. Whitney W.R. (1903): The corrosion of iron. J. Am. Chem. Soc. 25, 4, 394-406.

Wilkin R.T., Acree S.D., Ross R.R., Puls R.W., Lee T.R., Woods L.L. (2014): Fifteen-year assessment of a permeable reactive barrier for treatment of chromate and trichloroethylene in groundwater. Sci. Tot. Environ. 468-469, 186-194.

Xiao, M., Cui, X., Hu, R., Gwenzi, W., Noubactep, C. Validating the efficiency of the FeS2 method for elucidating the mechanisms of contaminant removal using $\mathrm{Fe}^{0} / \mathrm{H}_{2} \mathrm{O}$ systems. Processes 8, 1162 (2020). https://doi.org/10.3390/pr8091162

Xiao, M.; Hu, R.; Cui, X.; Gwenzi, W.; Noubactep, C. Understanding the operating mode of $\mathrm{Fe} 0 / \mathrm{Fe}-$ sulfide/H2O systems for water treatment. Processes 2020, 8, 409.

Yang H., Hu R., Ndé-Tchoupé A.I., Gwenzi W., Ruppert H., Noubactep C. (2020): Designing the next generation of $\mathrm{Fe}^{0}$-based filters for decentralized safe drinking water treatment. Processes 8, 745 .

Yang H., Hu R., Ruppert H., Noubactep C. (2021): Modeling porosity loss in $\mathrm{Fe}^{0}$-based permeable reactive barriers with Faraday's law. Sci. Rep. 11, 16998.

You, Y.; Han, J.; Chiu, P.C.; Jin, Y. (2005): Removal and inactivation of waterborne viruses using zerovalent iron. Environ. Sci. Technol. 2005, 39, 9263-9269. DOI: 10.1021/es050829j.

Zhao Y., Ren H., Dai H., Jin W. (2011): Composition and expansion coefficient of rust based on X-ray diffraction and thermal analysis. Corros. Sci. 53, 1646-1658. 
B.

Curriculum Vitae 


\section{Appendix}

- Equipment used for water analysis

- Practical example of calculation and ideas concerning porosity loss and clogging by using steel wool filters.

- Papers published in the framework of this work 


\section{- Equipment used for water analysis}

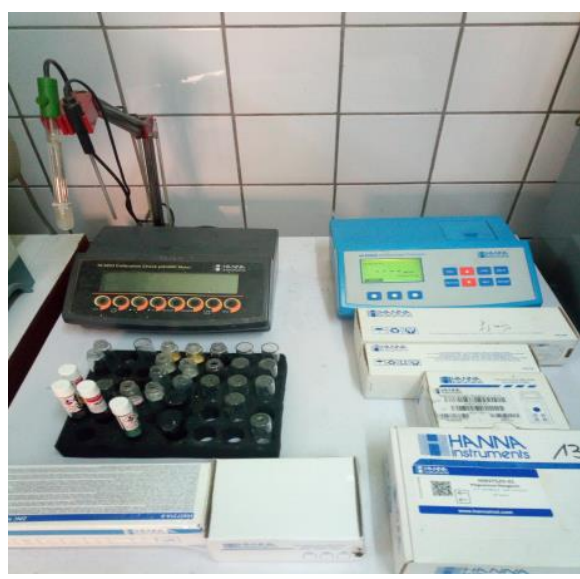

materials for physico-chemical analysis

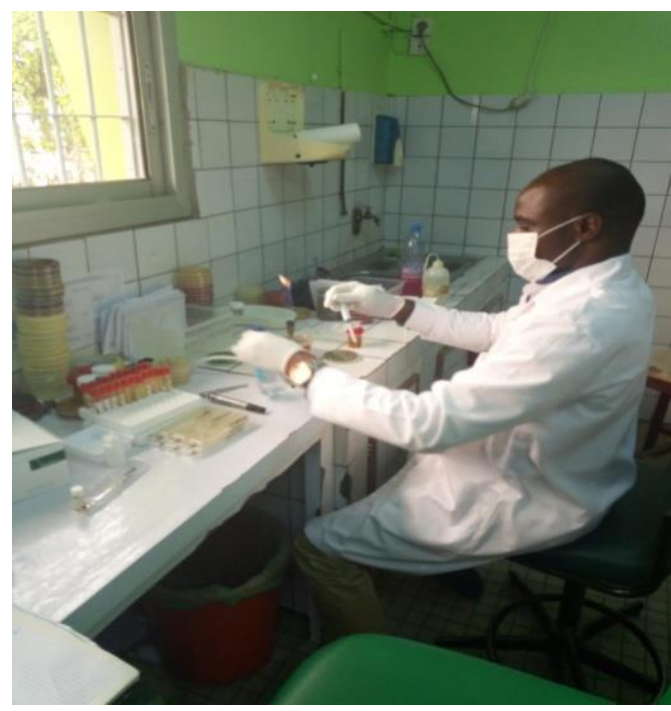

Inoculation of a water sample

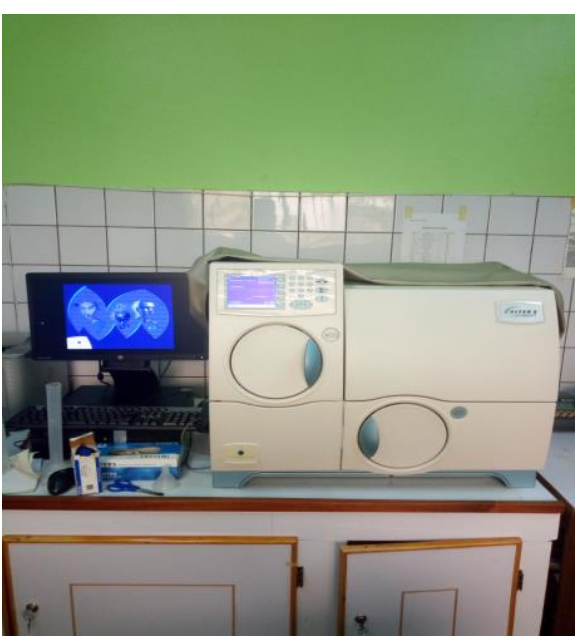

Vitex : germ identification device

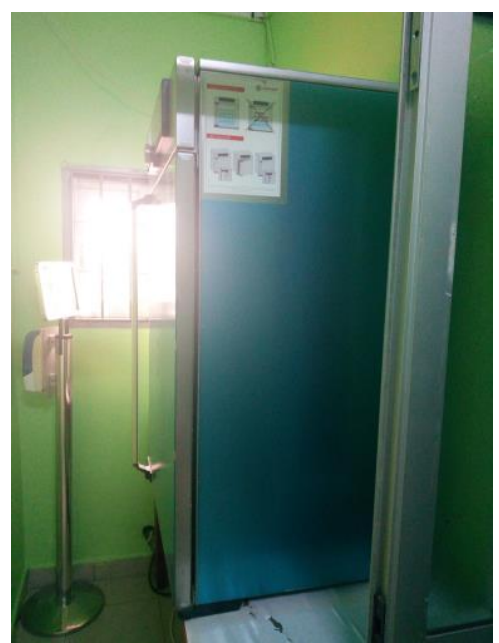

Bacterial incubator

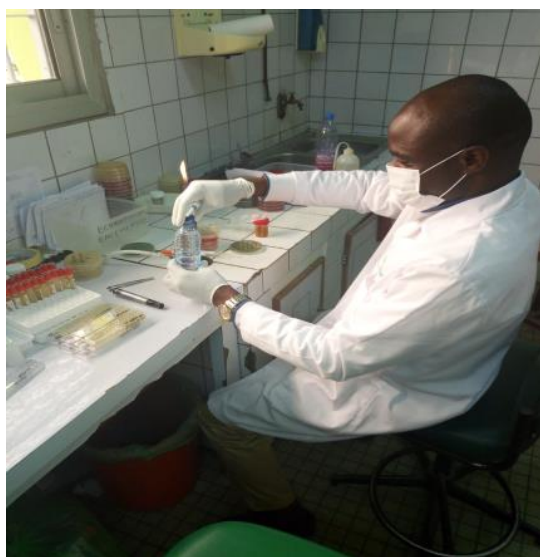

sample securing 


\section{Practical example of calculation and ideas concerning porosity loss and clogging by using steel wool filters.}

Assumption, calculations, and results in this part of work imply that per volume of sand it takes such a maximum quantity of iron to avoid clogging.

\section{Assumption:}

$100 \mathrm{~g} \mathrm{Fe}^{0}$ /sand mixture with 10 vol.\% steel wool +90 vol.\% coarse sand Fe concentration in the mixture: $2.07 \mathrm{wt} . \%=2.07 \mathrm{~g}$ per $100 \mathrm{~g}$ mixture

\section{Calculations:}

Full transformation of $2.07 \mathrm{~g} \mathrm{Fe}^{0}$ into ferrihydrite (assumed formula $\mathrm{Fe}(\mathrm{OH})_{3}$ ) : $2.07 * 1.9136$ $=3.96 \mathrm{wt} . \%$

This corresponds to $3.96 \mathrm{~g}$ ferrihydrite in $100+(3.96-2.07) \mathrm{g}=101,89 \mathrm{~g}$ mixture

Density of ferrihydrite: $3.8 \mathrm{~g} / \mathrm{cm}^{3} ; 3.96 \mathrm{~g}$ ferrihydrite per $101,89 \mathrm{~g}$ mixture correspond to 3.96 $/ 3.8=1.042 \mathrm{~cm}^{3}$

Density of $\mathrm{Fe}^{0}$ (not as steel wool): $7.87 \mathrm{~g} / \mathrm{cm} 3 ; 2.07 \mathrm{~g} \mathrm{Fe}^{0}$ per $100 \mathrm{~g}$ mixture correspond to $2.07 / 7.87=0.263 \mathrm{~cm}^{3}$

\section{Result:}

The volume of $\mathrm{Fe}^{0}$ of $0.263 \mathrm{~cm}^{3}$ increased to $1.042 \mathrm{~cm}^{3}$ through complete oxidation into ferrihydrite. At the same time, the 10 vol.\% of the steel wool space are vacated. This means, that altogether the pore space increased through the oxidation by nearly 9 vol.\% (rough calculation with rounded numbers). In addition, we have a huge pore space between the sand grains of at maximum $26 \%$ (value for closest packing of spheres/round grains with equal diameter).

\section{Consequence:}

Through the application of voluminous steel wool, as used in the manuscript, a clogging of the filters through oxidation of $\mathrm{Fe}^{0}$ can never happen, even at very high steel wool concentrations. On the contrary, steel wool amended filters should get an increased porosity in the iron-containing section. Fig.10 illustrate a cake formed in the filter during the elapsed time of 1 year. 


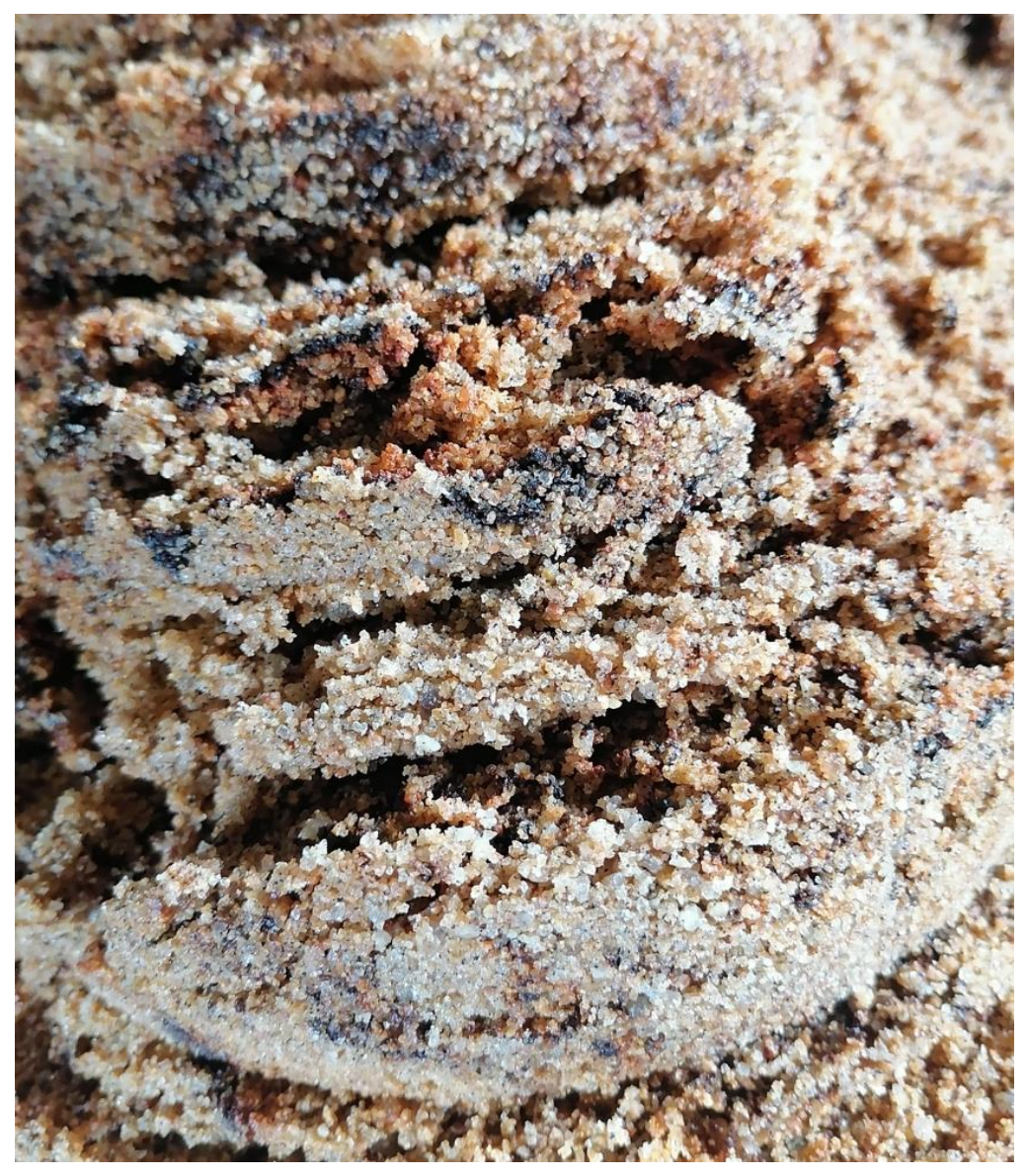

Picture of cake formed in the filter during the elapsed time of 1 year.

However, clogging could occur, if the formed ferrihydrite gels/nanoparticles would move up in the column and would accumulate in certain layers. Another explanation: under sub/anox conditions $\mathrm{Fe}^{2+}$ may migrate and accumulate in more oxidizing layers. The understanding of formation and transport behavior of the formed oxidized iron phase(s) is the key for understanding an eventual clogging. 
Article

\title{
Characterizing a Newly Designed Steel-Wool-Based Household Filter for Safe Drinking Water Provision: Hydraulic Conductivity and Efficiency for Pathogen Removal
}

\author{
Raoul Tepong-Tsindé ${ }^{1}$, Arnaud Igor Ndé-Tchoupé ${ }^{2}$, Chicgoua Noubactep ${ }^{1 *}$, Achille Nassi ${ }^{2}$ and \\ Hans Ruppert 3,* \\ 1 Department of Applied Geology, University of Göttingen, Goldschmidtstraße 3, D-37077 Göttingen, \\ Germany; raoultepong@googlemail.com \\ 2 Department of Chemistry, Faculty of Sciences, University of Douala, B.P. Douala 24157, Cameroon; \\ ndetchoupe@gmail.com (A.I.N.-T.); achillen@yahoo.fr (A.N.) \\ 3 Department of Sedimentology \& Environmental Geology, University of Göttingen, Goldschmidtstraße 3, \\ D-37077 Göttingen, Germany \\ * Correspondence: cnoubac@gwdg.de (C.N.); hrupper@gwdg.de (H.R.)
}

Received: 23 November 2019; Accepted: 16 December 2019; Published: 17 December 2019

\begin{abstract}
This study characterizes the decrease of the hydraulic conductivity (permeability loss) of a metallic iron-based household water filter ( $\mathrm{Fe}^{0}$ filter) for a duration of 12 months. A commercial steel wool (SW) is used as $\mathrm{Fe}^{0}$ source. The $\mathrm{Fe}^{0}$ unit containing $300 \mathrm{~g}$ of SW was sandwiched between two conventional biological sand filters (BSFs). The working solution was slightly turbid natural

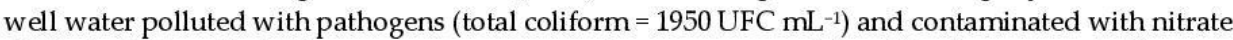
$\left(\left[\mathrm{NO}_{3}{ }^{-}\right]=24.0 \mathrm{mg} \mathrm{L}^{-1}\right)$. The system was monitored twice per month for $\mathrm{pH}$ value, removal of nitrate, coliforms, and turbidity, the iron concentration, as well as the permeability loss. Results revealed a quantitative removal of coliform $(>99 \%)$, nitrate $(>99 \%)$ and turbidity $(>96 \%)$. The whole column effluent depicted drinking water quality. The permeability loss after one year of operation was about $40 \%$, and the filter was still producing $200 \mathrm{~L}$ of drinking water per day at a flow velocity of $12.5 \mathrm{~L} \mathrm{~h}^{-1}$. A progressive increase of the effluent $\mathrm{pH}$ value was also recorded from about 5.0 (influent) to 8.4 at the end of the experiment. The effluent iron concentration was constantly lower than 0.2 $\mathrm{mg} \mathrm{L} \mathrm{L}^{-1}$, which is within the drinking-water quality standards. This study presents an affordable design that can be one-to-one translated into the real world to accelerate the achievement of the UN Sustainable Development Goals for safe drinking water.
\end{abstract}

Keywords: biosand filter; household filter; pathogen removal; permeability loss; zero-valent iron

\section{Introduction}

Accelerating universal access to safe drinking water (and sanitation) is the aim of the United Nations Sustainable Development Goals (SDG's six) [1,2]. "Leaving no one behind" without safe drinking water can only be achieved if efficient and affordable technologies are made available to people where they are currently living, including in their remote and scattered rural homes and in slums of crowded cities. Clearly, decentralized solutions, such as small-scale water treatment units, are needed [3-5]. Water filtration on granular $\mathrm{Fe}^{0}$ beds has been demonstrated to be one such affordable technology [2,6-9]. However, the large-scale implementation of $\mathrm{Fe}^{0}$ filters is impaired by several operational factors of which the decrease of the hydraulic conductivity (permeability loss) is the most crucial [10-12]. 
Gravity-driven $\mathrm{Fe}^{0}$ filters can be constructed, operated, and maintained by users with relatively low technical skills $[13,14]$. The present work is a part of an effort to facilitate the design of compact household $\mathrm{Fe}^{0}$ filters for the population of urban slums, taking Douala (Cameroon) as a model city [15]. Several conceptual filters were already discussed [16]. The present work presents the current state of efforts to characterize the longevity of a steel wool (SW)-based $\mathrm{Fe}^{0}$ filter in terms of permeability loss.

The tested water treatment train was conceptually derived from the seminal work of Westerhoff and James [16,17], wherein filtration is performed on a series of beds containing granular materials and including at least one biological sand filter (BSF) and one $\mathrm{Fe}^{\mathrm{o}} / \mathrm{sand}$ filter. BSFs preceding the $\mathrm{Fe}^{0} /$ sand filter(s) are designed to remove suspended solids by straining (size exclusion) and pathogens by metabolic breakdown, natural death, and predation [18,19]. However, because specific biological processes may also generate metal oxides and organic matter, quantitative scavenging chemical pollutants in BSFs have also been reported [20]. In this study, the removal of chemicals is mainly attributed to iron corrosion within $\mathrm{Fe}^{0} /$ sand columns $[9,16]$. BSFs coming after the $\mathrm{Fe}^{0} / \mathrm{sand}^{2}$ filter(s) act as a scavenger of dissolved $\mathrm{Fe}$ and can be regarded in the long-term as iron-oxide-coated sand units, able to remove pathogens and chemicals [21,22]. Clearly, the removal of pathogens and chemical contaminants in such designs is certain. The research question is how to design an efficient and sustainable system [8]. The main incertitude relies on the long-term permeability $[23,24]$.

The incertitude on the long-term permeability of $\mathrm{Fe}^{0}$ filters arises from the evidence that aqueous iron corrosion is a volumetric expansive process [25]. In fact, immersed $\mathrm{Fe}^{0}$ corrodes after reaction 1 (Equation (1)), and $\mathrm{Fe}(\mathrm{OH})_{2}$ is further transformed to various iron hydroxides and oxides (Equation (2)) [26]. Each iron oxide is larger in volume than the metallic iron (Voxide $>V_{\text {iron }}$ ) [25-27].

$$
\begin{gathered}
\mathrm{Fe}^{0}+2 \mathrm{H}_{2} \mathrm{O} \Rightarrow \mathrm{Fe}(\mathrm{OH})_{2}+\mathrm{H}_{2} \\
\mathrm{Fe}(\mathrm{OH})_{2} \Rightarrow \mathrm{Fe}^{\mathrm{II}} / \mathrm{Fe}^{\mathrm{III}} \text { and } \mathrm{Fe}^{\mathrm{III}} \text { hydroxide and oxides }
\end{gathered}
$$

Equations (1) and (2) imply that, at $\mathrm{pH}$ values of natural waters, $\mathrm{Fe}^{0}$ can universally be used to produce $\mathrm{H}_{2}$ and iron hydroxides/oxides. However, the kinetics and the extent of the generation of iron oxides have not been properly considered in past efforts $[24,28,29]$. On the other hand, it is known that: (i) the kinetics of iron corrosion are never linear [28-30], (ii) the size of $\mathrm{Fe}^{0}$ particles is a relevant parameter for the corrosion kinetics [22,23], and (iii) the service life of a hybrid $\mathrm{Fe}^{0}$ filter depends on its $\mathrm{Fe}^{0}$ content and the proportion of $\mathrm{Fe}^{0}$ in the (homogeneous) mixture [26].

Reports found in the literature on using $\mathrm{Fe}^{0} \mathrm{SW}$ for water treatment clearly demonstrate the need for systematic investigation to design sustainable SW-based filters [31]. For example, the filters of Laudale and Emmons [3] containing a pure $\mathrm{Fe}^{0} \mathrm{SW}$ layer were not sustainable (permeability loss). On the other hand, systems with SW ratios lower than $10 \%(\mathrm{w} / \mathrm{w})$ have not experienced any permeability loss [32,33]. The region between $10 \%$ and $100 \% \mathrm{Fe}^{0} \mathrm{SW}(\mathrm{w} / \mathrm{w})$ in filtration systems is yet to be investigated. It is theoretically established [27] and experimentally confirmed [34] that lower $\mathrm{Fe}^{0}$ ratios warrant a system's sustainability (long-term permeability) while higher $\mathrm{Fe}^{0}$ ratios care for higher efficiency. Thus, having an appropriate balance between reactive $\mathrm{Fe}^{0}$ and a less or non-reactive aggregate (e.g., gravel, pumice, sand) is essential for an efficient and sustainable $\mathrm{Fe}^{0}$ filter [23].

Insufficient information is available to determine the feasibility of using $\mathrm{Fe}^{0} \mathrm{SW}$ to design a household water filter. Despite its worldwide availability, steel wool has only been scarcely tested for situations applicable to decentralized safe drinking water provision [22,35-39]. Among these works, only the last two referenced performed column studies. Rao and Murthy [39] filled the hollow portion of an existing domestic candle filter with $\mathrm{Fe}^{0} \mathrm{SW}(100 \%)$ and tested its suitability for As removal. Bradley et al. [22] mixed $260 \mathrm{~g}$ of a Fe ${ }^{0} \mathrm{SW}$ (extra fine or grade 0000) with sieved sand (effective size $0.4 \mathrm{~mm}$ ) to form a $20 \mathrm{~cm}$-thick filter for virus removal for 300 days ( 10 months). The authors reported that the used SW $\left(\mathrm{d}_{1}=25 \mathrm{~mm}\right)$ was completely depleted after 170 days ( 8 months) while the system was still permeable. On the contrary, George and Ahammed [40] tested a filter containing iron nails $\left(\mathrm{d}_{2}=2.0 \mathrm{~mm}\right)$ for just four months and did not consider Bradley et al. [22] while discussing their results. Using a larger particle $\left(\mathrm{d}_{2} / \mathrm{d}_{1}=80\right)$ and testing it for a shorter experimental duration $\left(t_{1} / t_{2}=2.5\right)$ is counter-intuitive, particularly in a context where long-term experiments are 
needed $[2,9]$. There is a need to further investigate the relationship between SW proportion in a $\mathrm{Fe}^{0}$ filter, its long-term permeability and its efficiency for water treatment [19,41,42].

The objective of this work was to characterize long-term changes of the hydraulic conductivity (permeability loss) of a newly designed $\mathrm{Fe}^{0} \mathrm{SW}$ household water filter. The tested $\mathrm{Fe}^{0} \mathrm{SW}$ filter is considered as a "black box" made up of three columns (Figure 1). The compact system comprised a $\mathrm{Fe}^{0}$ /sand filter sandwiched between two biological sand filters (BSF) and was intermittently fed by natural well water. The well water was slightly turbid, polluted with pathogens, and contaminated with $\mathrm{NO}_{3}{ }^{-}$. The experiment lasted for one year.

\section{Materials and Methods}

\subsection{Filter Characteristics}

The tested design is made up of three identical cylindrical Plexiglass columns (length: $100 \mathrm{~cm}$; inner diameter: $20.0 \mathrm{~cm}$ ) mounted in series - two conventional BSFs and one $\mathrm{Fe}^{0} \mathrm{SW}$ unit in between. Upon successful testing, the unit is intended to be transferred for use in households, but with a proper housing (e.g., concrete material). The test device was constructed inside a room of the Institute of Applied Technology in Douala (Cameroon). The used room was not a conventional experimental laboratory but offered representative conditions for a household situation. The room temperature range was $26 \pm 2{ }^{\circ} \mathrm{C}$.

The columns were connected to each other by using a $1.5 \mathrm{~m}$ PET (poly-ethylene terephthalate) tube of $2.4 \mathrm{~cm}$ inner diameter. The columns were packed from the bottom to the top as follows (Table

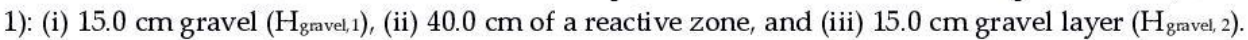
For column 1 and 3 , the reactive zone was a fine sand layer $\left(\mathrm{H}_{\text {sand, }}\right)$. For column 2, the $40 \mathrm{~cm}$ was filled with a $30.0 \mathrm{~cm}$ reactive zone $\left(\mathrm{H}_{\mathrm{rz}}\right)$ made up of a mixture of $\mathrm{Fe}^{0} \mathrm{SW}$ and coarse sand $\left(\mathrm{Fe}{ }^{0} / \mathrm{sand}\right)$ and sandwiched between two $5.0 \mathrm{~cm}$ fine sand layers $\left(\mathrm{H}_{\text {sand, }}\right)$.

The reactive layer was prepared by carefully introducing sand grains and chopped $\mathrm{Fe}^{0} \mathrm{SW}$ in small lofts into the column. The $\mathrm{Fe}^{0} / \mathrm{sand}$ mixture $(10 \% \mathrm{SW}-\mathrm{vol} / \mathrm{vol})$ was previously mixed in a large beaker. Once in the column, water was added to the mixture and it was gently compacted by manual tapping using a $100 \mathrm{~mL}$ PET bottle filled with water. The $300 \mathrm{~g}$ of $\mathrm{Fe}^{0} \mathrm{SW}$ and $14,200 \mathrm{~g}$ of coarse sand had a corresponding $\mathrm{Fe}^{0}$ weight ratio of $2.07 \%$. Bradley et al. [22] also reported on such a low weight percentage of $\mathrm{Fe}^{0} \mathrm{SW}$ in a Fe$/$ sand filter. This is justified by the very low density of SW (low weight and large volume). To build a $20 \mathrm{~cm}$ reactive layer under their experimental conditions, Bradley et al. [22] used $260 \mathrm{~g}$ of $\mathrm{Fe}^{0} \mathrm{SW}$.

Table 1. Summary of the used experimental setup. $\mathrm{H}_{\text {gravel } 1}$ and $\mathrm{H}_{\text {gravel } 2}$ are the heights of the underdrain and the upper layer, respectively; $\mathrm{H}_{\text {sand1 } 1}$ and $\mathrm{H}_{\text {sand2 } 2}$ the heights of fine sand; $\mathrm{H}_{\text {sand }}$ is the fine sand layer; and $\mathrm{Hrz}$ is the height of the reactive layer ( $\mathrm{Fe}^{\%} /$ sand coarse).

\begin{tabular}{cccc}
\hline Designation & \multicolumn{2}{c}{ Height (cm) } & \\
\hline & Column 1 & Column 2 & Column 3 \\
\hline Gravel $\left(\mathrm{H}_{\text {grave } 1)}\right)$ & 15.0 & 15.0 & 15.0 \\
\hline Sand $\left(\mathrm{H}_{\text {Sand2 }}\right)$ & - & 5.0 & - \\
\hline Sand $\left(\mathrm{H}_{\text {Sand1 })}\right.$ & 40.0 & - & 40.0 \\
\hline $\mathrm{RZ}\left(\mathrm{Fe}^{0} /\right.$ coarse sand) $(\mathrm{HRz})$ & - & 30.0 & - \\
\hline Sand $\left(\mathrm{H}_{\text {Sand2 }}\right)$ & - & 5.0 & - \\
\hline Gravel $\left(\mathrm{H}_{\text {grave } 2)}\right.$ & 15.0 & 15.0 & 15.0 \\
\hline
\end{tabular}

The total depth of materials in each column was $70.0 \mathrm{~cm}$ 


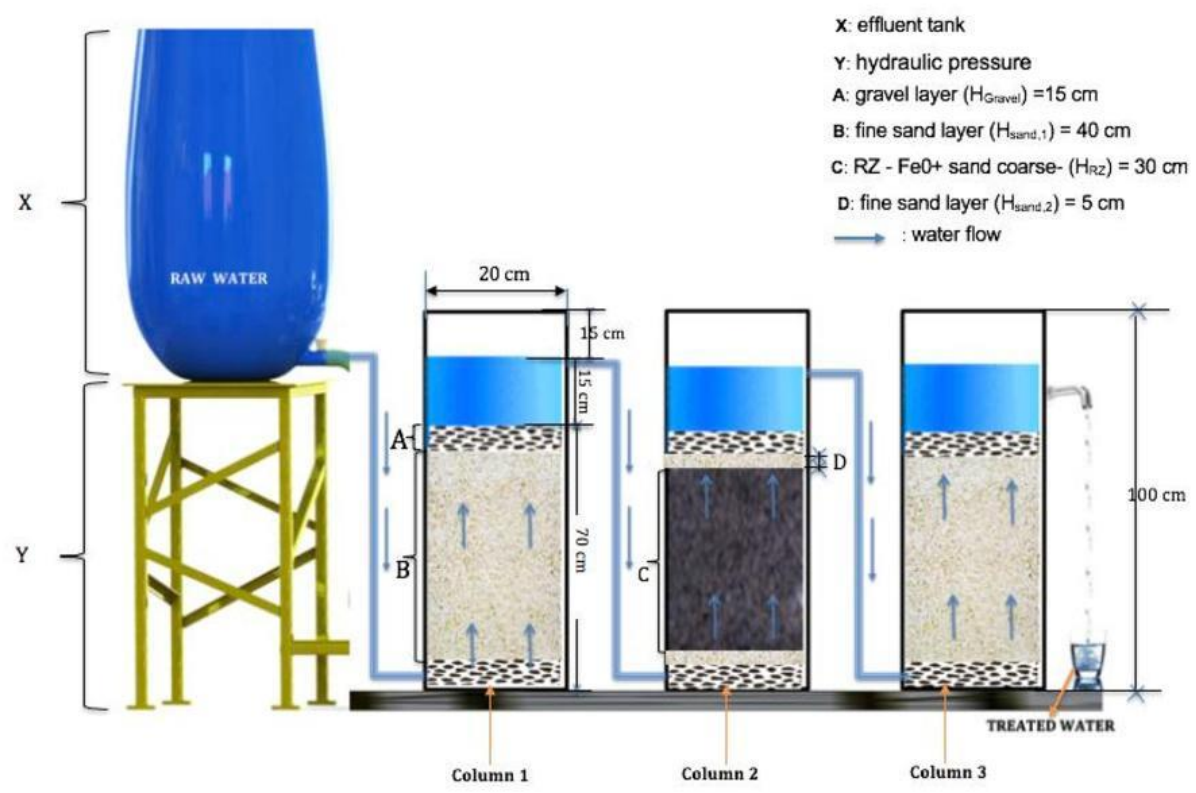

Figure 1. Schematic diagram of the designed filtration system. Well water was stored in a $200 \mathrm{~L}$ tank. The first and the third columns are conventional biosand filters (BSFs). The column in the middle is the $\mathrm{Fe}^{0}$ steel wool (SW) unit. The columns are connected to each other with a PET tube.

\subsection{Media and Their Preparation for Filter}

\subsubsection{Sand}

The used sand was a natural material from the Mungo River (Cameroon). Mungo sand was selectively sieved, using a set of sieves for sand analysis. The portion passing through a $1.0 \mathrm{~mm}$ sieve and retained by a $0.200 \mathrm{~mm}$ sieve was used as filter media in the BSFs and to build the separation layers $\left(\mathrm{H}_{\text {sand1 }}\right.$ and $\left.\mathrm{H}_{\mathrm{sand}} 2\right)$. Coarse sand $(1.00-4.00 \mathrm{~mm})$ was mixed with $\mathrm{Fe}^{0} \mathrm{SW}$ to build the reactive zone. The original Mungo sand was washed several times using tap water until the wash water became clear. Retained fractions were separately warmed in boiling water for about $3.0 \mathrm{~h}$. The sand was further dried in the sun for about $6.0 \mathrm{~h}$. Sand was used because of its worldwide availability and its use as a typical admixing agent in $\mathrm{Fe} / \mathrm{H}_{2} \mathrm{O}$ systems $[17,43]$.

\subsubsection{Gravel}

The used gravel $(4.00-8.0 \mathrm{~mm})$ was a natural material from a small river located in the vicinity of the University of Douala. Gravel was pre-treated like coarse sand and used as supporting layer and top layer in individual columns. The bottom gravel layer stores solids removed from raw water entering the first column (Figure 1). Gravel also prevents sand particles from falling and obstructing the inlet pipe.

\subsubsection{Metallic Iron}

A fine-grade $\mathrm{Fe}^{0} \mathrm{SW}$ (grade 0) from "Grand Menage" trademark brand purchased in Douala (Cameroon) was used. Its average elemental composition was not determined as it was proven to not be a stand-alone determining reactivity parameter for $\mathrm{Fe}^{0}$ in general. Recently, Lufingo et al. [31] presented the first systematic study comparing the intrinsic reactivity of $\mathrm{Fe}^{0} \mathrm{SW}$. The elemental 
composition (\%) of the grade $0(d=50 \mu \mathrm{m})$ material they tested was: $\mathrm{Fe}: 99.08 ; \mathrm{Co}: 0.05 ; \mathrm{Cu}: 0.27 ; \mathrm{Ni}$ : 0.11 ; and $\mathrm{Cr}: 0.49$. $\mathrm{Fe}^{0} \mathrm{SW}$ was chopped in sections of 1.0 to $5.0 \mathrm{~mm}$ length to use as a generator of iron hydroxides for contaminant scavenging $[8,21,44]$.

\subsection{Experimental Procedure}

An intermittent gravity-driven filtration was performed for one year. Each filtration event was initiated by opening the outlet-controlled tap connected to column 1 and allowing the stored well water from the reservoir to flow through the entire system (Figure 1). Experiments were conducted on a daily basis from Monday to Friday. Two hundred liters of water was filtered per filtration event. Raw water was collected from a well used for drinking and other domestic purposes (Table 2). The well water was polluted with microorganisms; there was no need for artificially seeding it. The volume of effluent recorded during the first $10 \mathrm{~min}$ was used to calculate the flow velocity. At the end of the filtration event, the reservoir was immediately refilled with $200 \mathrm{~L}$ well water. The initial flow rate was $0.34 \mathrm{~L} \mathrm{mn}^{-1}\left(20.40 \mathrm{~L} \mathrm{~h}^{-1}\right)$ and was not further modified. This approach perfectly mimics pilot-scale intermittent filtration using household filters for daily water need in low-income communities. Previous investigations on lab-scale using gravity-fed systems also filtered a constant volume daily $[45,46]$. In such an approach, changes in flow velocity are observed through variations of the recorded water volume during the fixed time (herein, $10 \mathrm{~min}$ ). The $\mathrm{pH}$ value, the iron level, and the extent of water decontamination were monitored. Complete water analysis including for pathogen was performed twice per month at the Centre Pasteur in Douala.

\subsubsection{Sample Collection}

The $1 \mathrm{~L}$ sample bottles were provided by the Laboratory at the Centre Pasteur du Cameroon (Douala) and used to collect water samples from the filter twice per month for microbial analysis. These samples included the raw water from a private well (Table 2). The time from sample collection and transportation to the lab was less than 4 hours. It is considered that the effects of time and temperature on microbial survival is negligible.

\subsubsection{Efficiency Characterization}

The efficacy of the designed filter to treat water was accessed by the extent of reducing the concentration of fecal coliform (FC) and total coliform (TC). In addition, turbidity, permeability loss, nitrate, and iron concentration were monitored.

Table 2. Average composition of the used well water. The well is polluted with coliforms and depicts high levels of conductivity and turbidity compared to the WHO guidelines [1]. WHO stands for World Health Organization.

\begin{tabular}{|c|c|c|c|}
\hline Parameter & Unit & Well Water & WHO (Guideline) \\
\hline Turbidity & (NTU) & $35 \pm 2$ & $<5$ \\
\hline Conductivity & $\left(\mu \mathrm{S} \mathrm{cm}^{-1}\right)$ & $296 \pm 7$ & 250 \\
\hline Total Iron & $\left(\mathrm{mg} \mathrm{L}^{-1}\right)$ & $1.45 \pm 0.25$ & $<0.2$ \\
\hline Nitrate & $\left(\mathrm{mg} \mathrm{L}^{-1}\right)$ & $23.5 \pm 4.5$ & $<50$ \\
\hline $\mathrm{pH}$ value $\left(25^{\circ} \mathrm{C}\right)$ & $(-)$ & $4.9 \pm 0.2$ & $6.5-8.5$ \\
\hline Total coliform (TC) & $\left(\mathrm{UFC} \mathrm{mL}^{-1}\right.$ ) & $1948.6 \pm 45$ & 0.0 \\
\hline Fecal coliforms (FC) & (UFC mL $\mathrm{mL}^{-1}$ ) & $1495.0 \pm 97$ & 0.0 \\
\hline
\end{tabular}

\subsection{Analytical Method}

Iron concentrations were determined by using a UV-Vis spectrophotometer (Dr. Lange CADAS 200 LPG 392). The working wavelength was $510 \mathrm{~nm}$. A cuvette with $1.0 \mathrm{~cm}$ light path was used. The iron determination followed the O-Phenanthroline method $[47,48]$. The spectrophotometer was calibrated for iron concentrations $\leq 10.0 \mathrm{mg} \mathrm{L}^{-1}$. The $\mathrm{pH}$ values were measured by a WTW $\mathrm{pH}$ meter. Conductivity was analyzed by the ISO 7888 method using a portable (WTW 340i) conductivity meter 
with automatic temperature compensation, so that all results refer to $20^{\circ} \mathrm{C}$. All other parameters including turbidity and biological analysis were performed at the laboratory of the Institute Louis Pasteur in Douala.

\subsection{Expression of Experimental Results}

\subsubsection{Value of $\mathrm{E}$}

To characterize the extent of the decontamination for individual contaminants (e.g., coliform, nitrate, turbidity), the effectiveness of the treatment (E) or attenuation percentage was calculated as follows (Equation (3)):

$$
E=\left[1-\left(C / C_{0}\right)\right] \times 100
$$

where $\mathrm{C}$ is the concentration after the experiment (residual effluent concentration), and $\mathrm{C}_{0}$ the initial aqueous concentration (initial influent concentration). The effectiveness comprises adsorption in the filter and possible other reactions that may occur during water throughput.

\subsubsection{Hydraulic Conductivity}

Changes of the hydraulic conductivity (permeability) were characterized by calculating the relative permeability " $\phi$ " (in\%) at each filtration event using Equation (4):

$$
\phi=100 \times \phi / \phi 0
$$

where $\phi_{0}$ is the initial value of the hydraulic conductivity and $\phi$ its value at a later time.

\section{Results and Discussion}

\subsection{Hydraulic Conductivity}

Figure 2 and Table 3 (row 3) summarize the changes of relative filtration rate $(\phi)$ in the investigated filter. The results of a primary experiment for 6 months with a $50: 50 \mathrm{Fe}^{0} / \mathrm{sand}$ volumetric ratio (experiment 1 ) are also shown. It is seen that the filter in experiment 1 was not sustainable as an almost $90 \%$ permeability loss was observed [15]. The present experiment with a $10 \% \mathrm{Fe}^{0}(\mathrm{vol} / \mathrm{vol})$ was designed accordingly (experiment 2). The results of experiment 1 depict the typical profile of permeability loss in $\mathrm{Fe}^{0}$-based filtration systems $[17,49]$ with the $\phi$ value dropping very abruptly. This behavior has been attributed to a local formation of a cake within the filter [50]. Clearly the system stays still mostly porous, but the inter-connectivity is suppressed in a domain where cake is formed. This is a testimony that the used $\mathrm{Fe}^{0}$ ratio is too high [23].

The progressive decrease of the $\phi$ values observed herein ( $40 \%$ in 12 months) was mainly attributed to iron corrosion. This assumption is supported by results of George and Ahammed [40] who performed similar experiments but with three individual systems (BSF and $\mathrm{Fe}^{0}$-amended BSF) for 4 months. The $\phi$ values were $50.0 \%, 42.9 \%$, and $15.6 \%$ for the systems $\mathrm{Fe}^{0}$-nails $/ \mathrm{sand} \mathrm{Fe}^{0}-$ scrap/sand, and BSF respectively. While George and Ahammed [40] are still speculating about the presence of $\mathrm{Fe}^{0}$ as cause of decline in flow rate, the present study was designed to verify the textbook knowledge that iron corrosion is a volumetric expansive process [26], which implies that systems with lower $\mathrm{Fe}^{0}$ ratios are more permeable $[15,16,23,27,34]$.

The design tested herein, a Fe ${ }^{0} \mathrm{SW}$ filter sandwiched between two BSF filters, was an attempt to prolong the service life of the filter by consuming dissolved $\mathrm{O}_{2}$ in the first BSF, therefore operating under $\mathrm{O}_{2}$ low conditions and avoiding rapid system clogging $[16,51]$. The second BSF was used as $\mathrm{Fe}$ scavenger, to fix iron escaping from the $\mathrm{Fe}^{0}$ filter. The results of George and Ahammed [40] confirmed the $\mathrm{O}_{2}$ scavenging nature of both $\mathrm{BSF}$ and $\mathrm{Fe}^{0}$ filters. Mackenzie et al. [49] and Westerhoff and James [17] also used hybrid $\mathrm{Fe}^{0} /$ sand layers as $\mathrm{O}_{2}$ scavengers to sustain the efficiency of $\mathrm{Fe}^{0} / \mathrm{H}_{2} \mathrm{O}$ systems.

The qualitative similitude between this work and that of George and Ahammed [40] should not be overemphasized. This study used $300 \mathrm{~g}$ of $\mathrm{Fe}^{0}$ SW making up a volumetric ratio of $10 \%$ while George and Ahammed [40] used $7.5 \mathrm{~kg}$ of mild steel nails and the same mass of scrap iron filing scrap 
uniformly mixed with sand throughout the reactive layer (Table 4). Given differences in key characteristics including density, form, intrinsic reactivity, and size, a quantitative comparison is difficult or even impossible. Obviously, under the respective operative conditions, the permeability loss at the end was acceptable.

The results achieved herein are more comparable to those of Bradley et al. [22]. The authors used a different grade of steel wool $(d=25 \mu \mathrm{m}$ vs. $50 \mu \mathrm{m}$ herein $)$ in the same volumetric percentage $(10 \%)$ and reported on completed SW depletion after 170 days (almost 6 months). Upon $\mathrm{Fe}^{0}$ depletion, the SW filter performed worse than the parallel operating BSF. This key observation was postulated by Noubactep et al. [51] and considered while designing the tested system [16]. In fact, $\mathrm{O}_{2}$ depleted by $\mathrm{Fe}^{0}$ is essential for the formation of the biofilm (Schmutzdecke), and pore filling by iron corrosion products have created preferential flow paths [52].

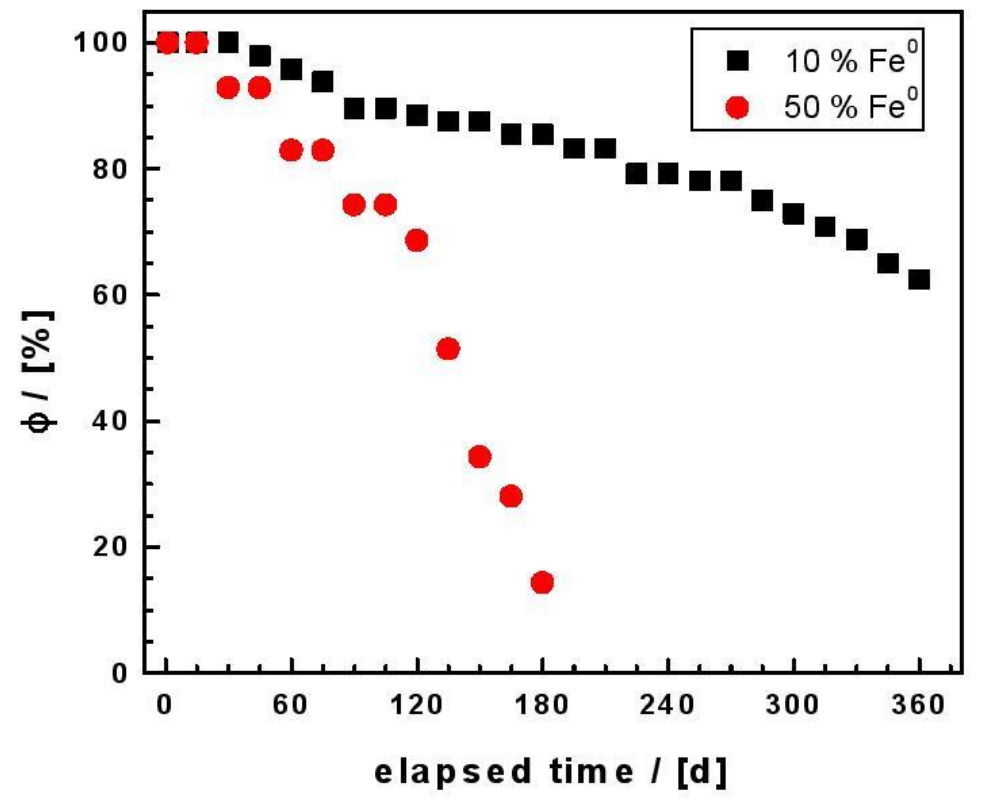

Figure 2. Flow rate variation over the length of filter runs for two different $\mathrm{Fe}^{0} \mathrm{SW}$ ratios (vol/vol): $50 \%$ and $10 \%$. Experimental conditions: $800 \mathrm{~g} \mathrm{SW}$ for $50 \% \mathrm{Fe}^{0}$ and $300 \mathrm{~g} \mathrm{SW}$ for $10 \% \mathrm{Fe}^{0}$; filling material: Sand. Column length $100 \mathrm{~cm}$, column diameter: $20 \mathrm{~cm}$. The system was fed by natural well water polluted by fecal coliforms.

Lufingo [53] recently presented the first systematic characterization of $\mathrm{Fe}^{0} \mathrm{SW}$ specimens using their own developed tool (the Phen test). His results confirm the observed trends that neither the elemental composition, the size, or the surface state alone determine the kinetics and the extent of $\mathrm{Fe}^{0}$ dissolution in aqueous solution [31]. However, because the $\mathrm{pH}$ value was still slightly increasing at the end of the experiment, it can be considered that SW was not depleted. Given that each natural water should be regarded as a unique system impacting the efficiency of $\mathrm{Fe}^{0}$ filters [9], the results achieved herein are not easily transferable to other locations with different water quality. The authors suggest, however, that it is possible to design an efficient SW containing $10 \% \mathrm{Fe}^{0}$ (vol/vol) for use at household level. More systematic research is needed using, for example, the seven grades of $\mathrm{Fe}^{0} \mathrm{SW}$ characterized by Lufingo et al. [31] in combination with typical model waters representing the most common water sources (surface water, less and more saline groundwater) [34]. 
Table 3. Characteristics of the effluent water over the testing period. The effluent iron concentration was constantly lower than the detection limit of the UV-Vis spectrophotometer $\left([\mathrm{Fe}]<0.2 \mathrm{mg} \mathrm{L}^{-1}\right)$. $\phi$ is the water flow velocity.

\begin{tabular}{|c|c|c|c|c|c|}
\hline$t$ & $\mathrm{pH}$ & $\phi$ & Total Coliforms & Turbidity & Nitrate \\
\hline (d) & $(-)$ & $\left(\mathrm{L} \mathrm{h}^{-1}\right)$ & $(\mathrm{CFU} / 100 \mathrm{~mL})$ & (NTU) & $\left(\mathrm{mg} \mathrm{L}^{-1}\right)$ \\
\hline Raw water & 4.9 & 0.0 & 1,950 & 35.0 & 24.0 \\
\hline 1 & 6.6 & 20.0 & 0.11 & 1.09 & 0.21 \\
\hline 15 & 6.7 & 20.0 & 0.11 & 1.07 & 0.19 \\
\hline 30 & 6.6 & 20.0 & 0.11 & 1.00 & 0.20 \\
\hline 45 & 6.8 & 20.0 & 0.10 & 1.00 & 0.20 \\
\hline 60 & 6.8 & 19.6 & 0.10 & 1.01 & 0.15 \\
\hline 75 & 6.9 & 19.6 & 0.10 & 1.00 & 0.15 \\
\hline 90 & 6.7 & 18.8 & 0.10 & 0.99 & 0.12 \\
\hline 105 & 6.6 & 18.8 & 0.08 & 0.80 & $<0.1$ \\
\hline 120 & 6.8 & 17.9 & 0.08 & 0.90 & $<0.1$ \\
\hline 135 & 7.0 & 17.5 & 0.08 & 0.90 & $<0.1$ \\
\hline 150 & 7.1 & 17.5 & 0.08 & 0.80 & $<0.1$ \\
\hline 165 & 7.3 & 17.1 & 0.08 & 0.80 & $<0.1$ \\
\hline 180 & 7.4 & 17.1 & 0.08 & 0.80 & $<0.1$ \\
\hline 195 & 7.5 & 16.7 & 0.02 & 0.90 & $<0.1$ \\
\hline 210 & 7.5 & 16.7 & $<0.02$ & 0.90 & $<0.1$ \\
\hline 225 & 7.5 & 15.8 & $<0.02$ & 0.80 & $<0.1$ \\
\hline 240 & 7.6 & 15.8 & $<0.02$ & 0.90 & $<0.1$ \\
\hline 255 & 7.6 & 15.6 & $<0.02$ & 0.90 & $<0.1$ \\
\hline 270 & 7.7 & 15.6 & $<0.02$ & 0.80 & $<0.1$ \\
\hline 285 & 7.5 & 15.0 & $<0.02$ & 0.80 & $<0.1$ \\
\hline 300 & 7.6 & 15.8 & $<0.02$ & 0.70 & $<0.1$ \\
\hline 315 & 7.9 & 15.2 & $<0.02$ & 0.80 & $<0.1$ \\
\hline 330 & 8.1 & 13.8 & $<0.02$ & 0.70 & $<0.1$ \\
\hline 345 & 8.3 & 13.0 & $<0.02$ & 0.80 & $<0.1$ \\
\hline 360 & 8.6 & 12.5 & $<0.02$ & 0.70 & $<0.1$ \\
\hline
\end{tabular}

Table 4. Summary of column dimension (length and diameter), the $\mathrm{Fe}^{0}$ to sand ratio, the initial flow velocity $\left(\phi_{0}\right)$, the experimental duration $(\mathrm{t}), \mathrm{Fe}^{0}$ type, and the used $\mathrm{Fe}^{0}$ mass of six selected peerreviewed articles using column experiments for the removal of biological contamination. It is seen that one paper has not explicitly given the experimental duration. The authors of reference [77] used the number of pore volumes in their discussion. Two papers tested periods exceeding four months (120 days). In general, there is a large variability of the considered operational parameters.

\begin{tabular}{|c|c|c|c|c|c|c|c|}
\hline $\mathrm{L}$ & D & $\mathrm{Fe}^{0} / \mathrm{S}$ and & $\phi_{0}$ & $t$ & $\mathrm{Fe}^{0} \mathrm{~T}$ ype & miron & Reference \\
\hline (cm) & (cm) & (vol/vol) & $\left(\mathrm{L} \mathrm{h}^{-1}\right)$ & (d) & $(-)$ & (kg) & \\
\hline 10 & 3.8 & $50: 50$ & 0.06 & 10 & granular & 0.15 & [75] \\
\hline 20 & n.s. & $10: 90$ & 0.03 & 300 & SW & 0.26 & [22] \\
\hline 0.77 & 0.14 & $50: 50 *$ & n.s. & 15 & granular & 23.0 & [76] \\
\hline 10 & 3.8 & $50: 50$ & 4.38 & n.s. & granular & n.s. & [77] \\
\hline non SI & non SI & $35: 65$ & 222 & 154 & granular & n.s. & [78] \\
\hline
\end{tabular}




\begin{tabular}{cccccccc}
\hline n.s. & n.s. & n.s. & n.s. & 120 & granular & 7.5 & {$[40]$} \\
\hline 100 & 20 & $10: 90$ & 20.4 & 365 & SW & 0.30 & This study \\
\hline
\end{tabular}

" is given in weight/weight; "n.s." stands for not specified and "non SI" for units given in a not known system, for example " 2 " $\times 2$ PVC plain-end pipe".

\subsection{Turbidity Removal}

Figure 3 and Table 3 (row 5) summarize the results of turbidity removal. The residual turbidity is listed, and the corresponding percent removal is depicted in Figure 3. The average influent turbidity was 35 NTU. The average effluent turbidity from the system was 0.7 NTU. The average turbidity removal efficiency from the influent was $>97.99 \%$ during the experiment. This corroborates the results of George and Ahammed [40] and Bradley et al. [22] reporting about quantitative turbidity removal in both BSF and $\mathrm{Fe}^{0}$-amended BSF. George and Ahammed [40] also reported that the amendment of $\mathrm{Fe}^{0}$ filters does not improve their turbidity removal efficiency. The results presented herein seem to confirm this assertion. However, this all depends on the design and the operational conditions. In essence, $\mathrm{Fe}^{0}$ amendment should improve turbidity removal because straining is improved by pore space reduction (expansive corrosion) [23].

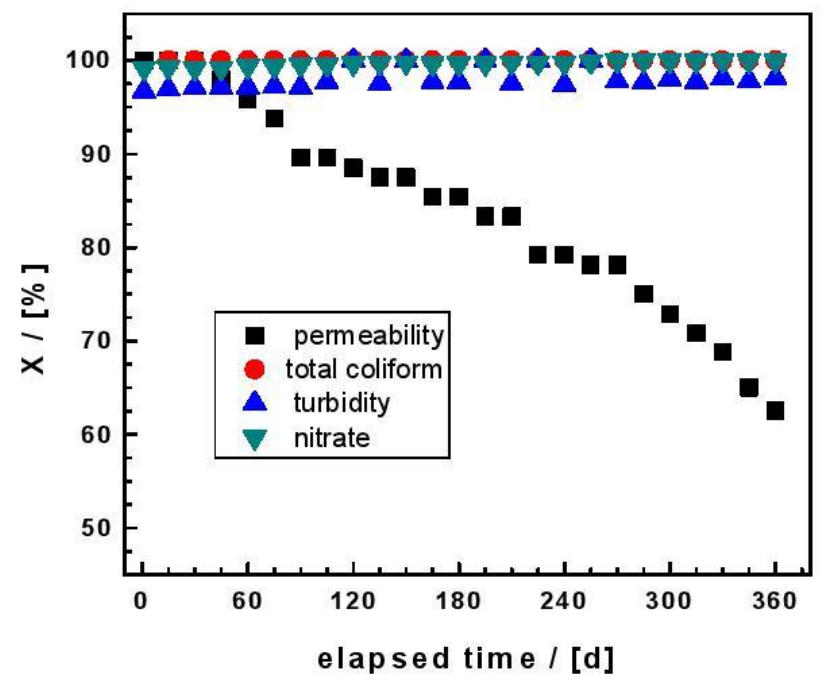

Figure 3. Permeability loss (percent) of the filter material and efficiencies of the removal of fecal coliform, turbidity, and nitrate (percent) in the effluent water over the length of filter run for the experiment with $10 \% \mathrm{Fe}^{0} \mathrm{SW}$ ( $\left.\mathrm{vol} / \mathrm{vol}\right)$. Experimental conditions: $300 \mathrm{~g} \mathrm{SW}$; filling material: Sand; column length $100 \mathrm{~cm}$, column diameter: $20 \mathrm{~cm}$. The system was fed by natural well water polluted by fecal coliform.

\subsection{Nitrate Removal}

Figure 3 and Table 3 (row 6) summarize the results of $\mathrm{NO}_{3}$ removal in the system. The corresponding percent removal is presented in Figure 3. The average influent $\mathrm{NO}_{3}-$ concentration was $23.5 \mathrm{mg} \mathrm{L}^{-1}$. Compared to the results of George and Ahammed [40], it is clear that $\mathrm{NO}_{3}^{-}$removal mainly occurs in the $\mathrm{Fe}^{0} \mathrm{SW}$ column. In fact, the authors spiked their influent solution with $26.0 \mathrm{mg}$ $\mathrm{L}^{-1} \mathrm{NO}_{3}^{-}$and observed $\mathrm{NO}_{3}^{-}$removal in all the three systems. The conventional BSF showed the lowest $\mathrm{NO}_{3}^{-}$removal. The $\mathrm{NO}_{3}{ }^{-}$removal in BSF is well-documented, but the removal is never 
quantitative $[54,55]$. Thus, al though the influent water used herein was not polluted by $\mathrm{NO}_{3}{ }^{-}$(Table 2 ), its removal was quantitative and occurred in the $\mathrm{Fe}^{0} \mathrm{SW}$ column [17].

The mechanism of $\mathrm{NO}_{3}{ }^{-}$removal is complex and implies microbiological process in the BSF units $[40,55]$ and both abiotic and biotic processes in the $\mathrm{Fe}^{0} \mathrm{SW}$ unit $[17,40]$.

\section{4. $p H$ Value and Iron Breakthrough}

Table 3 gives the $\mathrm{pH}$ values (row 2 ) in the system's effluent. No iron breakthrough was observed $\left([\mathrm{Fe}]<0.2 \mathrm{mg} \mathrm{L}^{-1}\right)$. It is seen that the $\mathrm{pH}$ value progressively increased within the operational time and reached 8.5 at the end of the experiments. The iron concentration was monitored to check whether any breakthrough occurred. The results showed that the second BSF quantitatively fixed iron for the whole duration of the experiment. Systems without scavenging BSF contain higher iron concentrations $[17,56]$. For example, Westerhoff and James [17] reported on up to $6 \mathrm{mg} \mathrm{L}^{-1} \mathrm{Fe}$ in their effluent solutions. The very low iron concentration recorded herein is also in agreement with the $\mathrm{pH}$ dependent solubility of Fe hydroxides [57] as discussed for the " $\mathrm{Fe}^{0}$ remediation" literature by Ghauch [58]. The fact that no iron breakthrough is observed herein suggests that the amount of iron (mainly $\mathrm{Fe}^{2+}$ ) escaping column 2 could not saturate the amount of sand in the second BSF. $\mathrm{Fe}^{2+}$ is adsorbed onto sand by pure electrostatic interactions $[46,59]$.

\subsection{Removal of Coliform}

Table 3 (row 4) and Figure 3 show reduction in total coliform concentration during the whole operation. There was a quantitative coliform removal already at the beginning of the experiment $(\mathrm{E}>$ $99.99 \%$ ), and this trend kept through to the end (one year). This is due to three synergy processes: (i) formation of the biofilm in BSF, (ii) in situ generation of iron corrosion products (FeCPs), and (iii) reduction of the filtration rate. As discussed in Section 3.1, accumulation of FeCPs reduces the porosity and the permeability. They also improve coliform removal through adsorption [22,51]. It is essential to recall that the intrinsic bacterial inactivation capacity of $\mathrm{Fe}^{0}$ was already reported in the 19th century [60-68] and has been independently demonstrated in the " $\mathrm{Fe}^{0}$ remediation" research [69-74]. In the 19th century, quantitative pathogen removal in $\mathrm{Fe}^{0}$ filters was demonstrated before the nature of individual bacteria was established. The diversity of microbiological populations in rivers and streams is obvious. On the contrary, current research efforts are demonstrating the efficiency of $\mathrm{Fe}^{0}$ filters for pathogen removal on a case-by-case basis [75-78]. For example, You et al. [75] (re)demonstrated the suitability of $\mathrm{Fe}^{\%}$ /sand filters to inactivate waterborne viruses and refs. [76] to [78] tested the same (e.g. $\mathrm{Fe}^{\mathrm{o}} / \mathrm{sand}$ filters) to remove various bacteria and viruses. Given that it is the dynamic process of aqueous iron corrosion which induces the remove all pathogens (Equations (1) and (2)), testing $\mathrm{Fe}^{0} /$ sand filters on a case-by-case basis can be regarded superfluous [9].

\subsection{Discussion}

Previous studies testing contaminant removal from water by using $\mathrm{Fe}^{0}$-based column household water filters are numerous [9]. They were mostly designed to test diverse $\mathrm{Fe}^{0}$ specimens for the removal of selected contaminants [40] and/or to compare the efficiency of $\mathrm{Fe}^{0}$ filters to that of other systems, including BSFs [51]. As recently stated by Hu and Noubactep [24], available results demonstrate the suitability of $\mathrm{Fe}^{0}$ filters for water treatment. However, results from independent research are difficult to compare to each other. This section illustrates this difficulty based on selected references on the removal of pathogens from water. The six selected publications (Table 4) were not only focused on pathogen removal. They were selected to reflect the large diversity of reported experimental conditions. Achieved results are not addressed; the focus is on operational conditions as they are determinant for achieved results but are rarely considered while discussing achieved results [9].

Six operational parameters were selected for this discussion: (i) the column dimensions (D and $\mathrm{L}$ ), (ii) the $\mathrm{Fe}^{\mathrm{0}}$ /sand ratio, (iii) the initial flow velocity ( $\mathrm{F}_{0}$ ), (iv) the experimental duration ( $\mathrm{t}$ ), (v) the $\mathrm{Fe}^{0}$ type, and (vi) the used $\mathrm{Fe}^{0}$ mass. It is seen that only $\mathrm{Fe}^{0} /$ sand ratio and the $\mathrm{Fe}^{0}$ type were specified 
by all six publications. The used volumetric $\mathrm{Fe}^{0}$ ratio varied between $10 \%$ and $50 \%$, while $\mathrm{Fe}^{0} \mathrm{SW}$ and granular materials were used. Concerning the column dimensions, small-scale columns and columns pertinent to pilot-scale tests were used while using flow velocities differing by more than three orders of magnitude. Lastly, 0.15 to $23 \mathrm{~kg}$ of Fe ${ }^{0}$ materials were used for operational duration varying from 10 to 365 days. There is no scientific basis to compare results from such experiments, particularly because the kinetics of iron corrosion are never linear, and the systems are dynamic in nature [24].

Table 4 clearly shows that a general weakness of the research projects undertaken to date on testing $\mathrm{Fe}^{0}$ systems for water treatment is that the long-term efficiency has not been investigated. Experiments designed for more than three months are in a large minority. This strategy is rather counter-intuitive in a context where long-term monitoring data are urgently needed $[9,24,79]$.

\subsection{Significance of the Results}

$\mathrm{Fe}^{0}$ materials have demonstrated their suitability for the design and dissemination of affordable, efficient, and sustainable safe drinking water provision systems over the past 170 years $[3,10,11,14,61,62,80,81]$. For the most recent success stories in decentralized systems, Hussam [11] used a proprietary material and Banerji and Chaudhari [14] used affordable iron nails. Progress in the large-scale realization of these and similar devices has been highly impeded by the lack of easy transferable designs. Using universally available steel wool $\left(\mathrm{Fe}^{0} \mathrm{SW}\right)$ in this study was a step toward achieving universal access to safe drinking water [2,8,15,16,41,42].

Based on a concept presented by Noubactep et al. [8] and a mathematical model reasonably predicting optimal $\mathrm{Fe}^{\%}$ ssand ratio for a sustainable filter [23,27], the present work has tested a volumetric $\mathrm{Fe}^{0} / \mathrm{sand}$ ratio of $10: 90\left(300 \mathrm{~g} \mathrm{Fe}^{0} \mathrm{SW}\right)$ and obtained a filter that is able to treat natural well water polluted with pathogens for one year while depicting a permeability loss of only $40 \%$. After one year the system was still capable of producing $200 \mathrm{~L}$ water per day, with an acceptable flow velocity $\left(12.5 \mathrm{~L} \mathrm{~h}^{-1}\right)$. This water volume is far above the needs of an average family. If it is assumed that each person needs $7.5 \mathrm{~L}$ water per day for drinking and cooking, the designed filter can supply 25 people with safe drinking water, whether they are living in a small village, an urban slum, or a modern city. The filter is relatively easy in design; the most challenging task is homogeneously building the reactive zone, giving the huge difference in density between $\mathrm{Fe}^{0} \mathrm{SW}$ and sand [22]. Herein, a dry packing approach in small lots was adopted. For future works, however, a wet packing approach as suggested by Sleiman et al. [82] should be tested. These authors pre-wetted the $\mathrm{Fe} / \mathrm{sand}$ mixture to facilitate homogeneous $\mathrm{Fe}^{0}$ distribution in the column.

It should be insisted on that the most important result here is that a column containing $10 \%$ of $\mathrm{Fe}^{0} \mathrm{SW}(\mathrm{vol} / \mathrm{vol})$ or just $2 \%(\mathrm{w} / \mathrm{w})$ and fed with natural water was still permeable after one year of operation. This result might not be reproduced by another $\mathrm{Fe}^{0} \mathrm{SW}$ or a different water source, but the $\mathrm{Fe}^{0}$ ratio can be further decreased (and the column length increased) until a satisfactory balance is identified for each specific case. Sleiman et al. [82] used just $1 \%$ of $\mathrm{Fe}^{0}$ in their systems while Erickson et al. [33] hardly used more than $5 \%(w / w)$. Clearly, there is room for adjusting the operational conditions to any site-specific situation. Where necessary, additional units made of affordable materials should be added to remove contaminants that are not well-addressed by $\mathrm{Fe}^{0} / \mathrm{H}_{2} \mathrm{O}$ systems $[3,9,83]$.

\section{Conclusions}

The results of the present study indicate a clear advancement in designing $\mathrm{Fe}^{0}$-based household water units by rationally combining BSF and $\mathrm{Fe}^{0}$ /sand filters. By using a comparable volumetric $\mathrm{Fe}^{0} / \mathrm{SW}$ ratio but a different $\mathrm{Fe}^{0} \mathrm{SW}$ grade than Bradley et al. [22], a system still depicting acceptable permeability after one year was obtained. The designed system was able to convert a polluted well water into clean drinking water according to WHO standards. Considering that the duration of effective decontamination of $\mathrm{Fe}^{0}$-based systems depends on both the water source and the nature of used $\mathrm{Fe}^{0}$, the achieved results are highly qualitative. The achieved results call for further systematic research, which can start by duplicating the experiments reported herein with the seven grades of $\mathrm{Fe}^{0}$ SW from the same supplier. 
Another field for future research is the characterization of the effects of typical water constituents on the efficiency of $\mathrm{Fe}^{0} \mathrm{SW}$ filters. Relevant parameters include the presence of $\mathrm{Cl}^{-}, \mathrm{HCO}_{3}$, humic substances, $\mathrm{SO}_{4}{ }^{2-}$, and $\mathrm{PO}_{4}{ }^{3-}$. The results of this study suggest that $\mathrm{Fe}^{0} \mathrm{SW}$ filters are very affordable as only small amount of cheap SW (here $300 \mathrm{~g}$ ) is required per household per year. Filter containers can be locally designed and constructed. A systematic approach for providing a chemistry-free, electricity-free barrier against waterborne diseases to millions of people based on SW filtration seems possible.

Author Contributions: The experiments were conceived and performed by R.T.-T., R.T.-T., A.I.N.-T., A.N., H.R., and C.N. contributed equally to manuscript compilation and revisions.

Funding: This research received no external funding.

Acknowledgments: The manuscript was improved thanks to the insightful comments of anonymous reviewers from Processes. We acknowledge support by the German Research Foundation and the Open Access Publication Funds of the Göttingen University.

Conflicts of Interest: The authors declare no conflict of interest.

\section{References}

1. Progress on Drinking Water, Sanitation and Hygiene-2017 Update and SDG Baselines; WHO JMP launch version July 12 2017; WHO Library Cataloguing-in-Publication Data; WHO: Geneva, Switzerland, 2017; doi:10.1007/s12686-011-9397-4.

2. Nanseu-Njiki, C.P.; Gwenzi, W.; Pengou, M.; Rahman, M.A.; Noubactep, C. $\mathrm{Fe}^{0} / \mathrm{H}_{2} \mathrm{O}$ filtration systems for decentralized safe drinking water: Where to from here? Water 2019, 11, 429.

3. Lauderdale, R.A.; Emmons, A.H. A method for decontaminating small volumes of radioactive water. J. Am. Water Works Assoc. 1951, 43, 327-331.

4. Baig, S.A.; Mahmood, Q.; Nawab, B.; Shafqat, M.N.; Pervez, A. Improvement of drinking water quality by using plant biomass through household biosand filter-A decentralized approach. Ecol. Eng. 2011, 37, 1842 1848.

5. Moglia, M.; Alexander, K.S.; Sharma, A. Discussion of the enabling environments for decentralised water systems. Water Sci. Technol. 2011, 63, 2331-2339.

6. Hussam, A.; Munir, A.K.M. A simple and effective arsenic filter based on composite iron matrix: Development and deployment studies for groundwater of Bangladesh. J. Environ. Sci. Health A 2007, 42, 1869-1878.

7. Ngai, T.K.K.; Murcott, S.; Shrestha, R.R.; Dangol, B.; Maharjan, M. Development and dissemination of Kanchan ${ }^{\mathrm{TM}}$ Arsenic Filter in rural Nepal. Water Sci. Technol. Water Supply 2006, 6, 137-146.

8. Noubactep, C.; Schöner, A.; Woafo, P. Metallic iron filters for universal access to safe drinking water. Clean Soil Air Water 2009, 37, 930-937.

9. Naseri, E.: Ndé-Tchoupé, A.I.; Mwakabona, H.T.; Nanseu-Njiki, C.P.; Noubactep, C.; Njau, K.N.; Wydra, K.D. Making $\mathrm{Fe}^{0}$-based filters a universal solution for safe drinking water provision. Sustainability 2017, 9, 1224.

10. Devonshire, E. The purification of water by means of metallic iron. J. Frankl. Inst. 1890, 129, 449-461.

11. Hussam, A. Contending with a Development Disaster: SONO Filters Remove Arsenic from Well Water in Bangladesh. Innovations 2009, 4, 89-102.

12. Henderson, A.D.; Demond, A.H. Impact of solids formation and gas production on the permeability of ZVI PRBs. J. Environ. Eng. 2011, 137, 689-696.

13. Ngai, T.K.K.; Shrestha, R.R.; Dangol, B.; Maharjan, M.; Murcott, S.E. Design for sustainable development Household drinking water filter for arsenic and pathogen treatment in Nepal. J. Environ. Sci. Health A 2007, $42,1879-1888$.

14. Banerii, T.; Chaudhari, S. A cost-effective technology for arsenic removal: Case study of zerovalent ironbased iit bombay arsenic filter in west bengal. In Water and Sanitation in the New Millennium; Nath, K., Sharma, V., Eds.; Springer: New Delhi, India, 2017.

15. Tepong-Tsindé, R. Metallic Iron Filters for Safe Drinking Water in Informal Settlements of Douala (Cameroun): A Pilot Scale Study. Ph.D. Thesis, University of Göttingen, Göttingen, Germany, 2020. 
16. Tepong-Tsindé, R.; Crane, R.; Noubactep, C.; Nassi, A.; Ruppert, H. Testing metallic iron filtration systems for decentralized water treatment at pilot scale. Water 2015, 7, 868-897.

17. Westerhoff, P.; James, J. Nitrate removal in zero-valent iron packed columns. Water Res. 2003, 37, 18181830 .

18. Ahammed, M.M.; Davra, K. Performance evaluation of biosand filter modified with iron oxide-coated sand for household treatment of drinking water. Desalination 2011, 276, 287-293.

19. Haig, S.J.; Collins, G.; Davies, R.L.; Dorea, C.C.; Quince, C. Biological aspects of slow sand filtration: Past, present and future. Water Sci. Technol. Water Supply 2011, 11, 468-472.

20. Nitzsche, K.S.; Lan, V.M.; Trang, P.T.K.; Viet, P.H.; Berg, M.; Voegelin, A.; Planer-Friedrich, B.; Zahoransky, J.; Müller, S.-K.; Byrne, J.M.; et al. Arsenic removal from drinking water by a household sand filter in Vietnam-Effect of filter usage practices on arsenic removal efficiency and microbiological water quality. Sci. Total Environ. 2015, 502, 526-536.

21. Jia, Y.; Aagaard, P.; Breedveld, G.D. Sorption of triazoles to soil and iron minerals. Chemosphere 2007, 67, 250-258.

22. Bradley, I.; Straub, A.; Maraccini, P.; Markazi, S.; Nguyen, T.H. Iron oxide amended biosand filters for virus removal. Water Res. 2011, 45, 4501-4510.

23. Domga, R.; Togue-Kamga, F.; Noubactep, C.; Tchatchueng, J.B. Discussing porosity loss of $\mathrm{Fe}^{0}$ packed water filters at ground level. Chem. Eng. J. 2015, 263, 127-134.

24. $\mathrm{Hu}, \mathrm{R}$; Noubactep, C. Redirecting research on $\mathrm{Fe}^{0}$ for environmental remediation: The search for synergy. Int. J. Environ. Res. Public Health 2019, 16, 4465.

25. Pilling, N.B.; Bedworth, R.E. The oxidation of metals at high temperatures. J. Inst. Met. 1923, 29, 529-591.

26. Landolt, D. Corrosion and Surface Chemistry of Metals, 1st ed.; EPFL Press: Lausanne, Switzerland, 2007; p. 615.

27. Caré, S.; Crane, R.; Calabrò, P.S.; Ghauch, A.; Temgoua, E.; Noubactep, C. Modeling the permeability loss of metallic iron water filtration systems. CLEAN Soil Air Water 2013, 41, 275-282.

28. Moraci, N.; Lelo, D.; Bilardi, S.; Calabrò, P.S. Modelling long-term hydraulic conductivity behaviour of zero valent iron column tests for permeable reactive barrier design. Can. Geotech. J. 2016, 53, 946-961.

29. Noubactep, C. Predicting the hydraulic conductivity of metallic iron filters: Modeling gone astray. Water 2016, 8, 162.

30. Hammonds, P. An Introduction to Corrosion and its Prevention (Chapter 4). Compr. Chem. Kinet. 1989, 28, 233-279.

31. Lufingo, M.; Ndé-Tchoupé, A.I.; Hu, R.; Njau, K.N.; Noubactep, C. A novel and facile method to characterize the suitability of metallic iron for water treatment. Water 2019, 11, 2465

32. Wakatsuki, T.; Esumi, H.; Omura, S. High performance and N, P removable on-site domestic wastewater treatment system by multi-soil-layering method. Water Sci. Technol. 1993, 27, 31-40.

33. Erickson, A.J.; Gulliver, J.S.; Weiss, P.T. Phosphate removal from agricultural tile drainage with iron enhanced sand. Water 2017, 9, 672 .

34. Luo, P.; Bailey, E.H.; Mooney, S.J. Quantification of changes in zero valent iron morphology using X-ray computed tomography. J. Environ. Sci. 2013, 25, 2344-2351.

35. Özer, A.; Altundogan, H.S.; Erdem, M.; Tümen, F. A study on the $\mathrm{Cr}$ (VI) removal from aqueous solutions by steel wool. Environ. Pollut. 1997, 97, 107-112.

36. Campos, V. The effect of carbon steel-wool in removal of arsenic from drinking water. Environ. Geol. 2002, $42,81-82$.

37. Cornejo, L.; Lienqueo, H.; Arenas, M.; Acarapi, J.; Contreras, D.; Yáñez, J.; Mansilla, H.D. In field arsenic removal from natural water by zero-valent iron assisted by solar radiation. Environ. Pollut. 2008, 156, 827831

38. Triszcz, J.M.; Porta, A.; Einschlag, F.S.G. Effect of operating conditions on iron corrosion rates in zero-valent iron systems for arsenic removal. Chem. Eng. J. 2009, 150, 431-439.

39. Rao, T.S.; Murthy, D.S. Removal of arsenic (V) from water by adsorption onto low-cost and waste materials. Int. J. Res. Eng. Technol. 2013, 2, 206-212.

40. George, D.; Ahammed, M.A. Effect of zero-valent iron amendment on the performance of biosand filters. Water Supply 2019, 19, 1612-1618.

41. Ndé-Tchoupé, A.I.; Crane, R.A.; Mwakabona, H.T.; Noubactep, C.; Njau, K.N. Technologies for decentralized fluoride removal: Testing metallic iron based filters. Water 2015, 7, 6750-6774. 
42. Ndé-Tchoupé, A.I. Design and Construction of Fe-Based Filters for Households. Ph.D. Thesis, University of Douala, Douala, Cameroon, 2019. (In French).

43. Varlikli, C.; Bekiari, V.; Kus, M.; Boduroglu, N.; Oner, I.; Lianos, P.; Lyberatos, G.; Icli, S. Adsorption of dyes on Sahara desert sand. J. Hazard. Mater. 2009, 170, 27-34.

44. James, B.R.; Rabenhorst, M.C.; Frigon, G.A. Phosphorus sorption by peat and sand amended with iron oxides or steel wool. Water Environ. Res. 1992, 64, 699-705.

45. Chiew, H.; Sampson, M.L.; Huch, S.; Ken, S.; Bostick, B.C. Effect of groundwater iron and phosphate on the efficacy of arsenic removal by iron-amended biosand filters. Environ. Sci. Technol. 2009, 43, 6295-6300.

46. Btatkeu-K., B.D.; Olvera-Vargas, H.; Tchatchueng, J.B.; Noubactep, C.; Caré, S. Determining the optimum $\mathrm{Fe}^{0}$ ratio for sustainable granular $\mathrm{Fe}$ /sand water filters. Chem. Eng. J. 2014, 247, 265-274.

47. Saywell, L.G.; Cunningham, B.B. Determination of iron: Colorimetric o-phenanthroline method. Ind. Eng. Chem. Anal. Ed. 1937, 9, 67-69.

48. Fortune, W.B.; Mellon, M.G., Determination of iron with o-phenanthroline. Ind. Eng. Chem. Anal. Ed. 1938, 10, 60-64.

49. Mackenzie, P.D.; Horney, D.P.; Sivavec, T.M. Mineral precipitation and porosity losses in granular iron columns. J. Hazard. Mater. 1999, 68, 1-17.

50. Santisukkasaem, U.; Das, D.B. A non-dimensional analysis of permeability loss in zero-valent iron permeable reactive barrier (PRB). Transp. Porous Media 2019, 126, 139-159.

51. Noubactep, C.; Temgoua, E.; Rahman, M.A. Designing iron-amended biosand filters for decentralized safe drinking water provision. CLEAN Soil Air Water 2012, 40, 798-807.

52. Miyajima, K. Optimizing the design of metallic iron filters for water treatment. Freib. Online Geosci. 2012, 32, 1-60.

53. Lufingo, M. Investigation of Metallic Iron for Water Defluoridation. Master's Thesis, Nelson Mandela African Institution of Science and Technology, Arusha, Tanzania, 2019.

54. Nakhla, G.; Farooq, S. Simultaneous nitrification-denitrification in slow sand filters. J. Hazard. Mater. 2003, 96, 291-303.

55. Murphy, H.M.; McBean, E.A.; Farahbakhsh, K. Nitrification, denitrification and ammonification in pointof-use biosand filters in rural Cambodia. J. Water Health 2010, 8, 803-817.

56. Heimann, S.; Ndé-Tchoupé, A.I.; Hu, R.; Licha, T.; Noubactep, C. Investigating the suitability of Fe ${ }^{0}$ packedbeds for water defluoridation. Chemosphere 2018, 209, 578-587.

57. Liu, X.; Millero, F.J. The solubility of iron hydroxide in sodium chloride solutions. Geochim. Cosmochim. Acta 1999, 63, 3487-3497.

58. Ghauch, A. Iron-based metallic systems: An excellent choice for sustainable water treatment. Freib. Online Geosci. 2015, 32, 1-80.

59. Btatkeu-K., B.D.; Olvera-Vargas, H.; Tchatchueng, J.B.; Noubactep, C.; Caré, S. Characterizing the impact of $\mathrm{MnO}_{2}$ on the efficiency of $\mathrm{Fe}^{0}$-based filtration systems. Chem. Eng. J. 2014, 250, 416-422.

60. Bischof, G. Über das Reinigen des Wassers und über die Wirkung des Eisenschwammes auf unreines Wasser. Polytech. J. 1873, 210, 40-59.

61. Bischof, G. On putrescent organic matter in potable water. Proc. R. Soc. Lond. 1877, 26, 258-261.

62. Bischof, G. On putrescent organic matter in potable water II. Proc. R. Soc. Lond. 1878, 27, 152-156.

63. Notter, J.L. The purification of water by filtration. Br. Med. J. 1878, Oct. 12, 556-557.

64. Hatton, F. On the oxidation of organic matter in water by filtration through various media; and on the reduction of nitrates by sewage, spongy iron, and other agents. J. Chem. Soc. Trans. 1881, 39, 258-276.

65. Bache, R.M. Possible sterilization of city water. Proc. Am. Phil. Soc. 1891, 29, 26-39.

66. Leffmann, H. The purification of water by metallic iron. In Proceedings of the 11th Annual Meeting of the American Water Works Association, Philadelphia, PA, USA, 14-16 April 1991; pp 163-171.

67. Tweeddale, W. Water purification. Trans. Ann. Meet. Kans. Acad. Sci. 1898, 16, 48-52.

68. Baker, M.N. Sketch of the history of water treatment. J. Am. Water Works Assoc. 1934, 26, 902-938.

69. Bojic, A.; Purenovic, M.; Kocic, B.; Perovic, J.; Ursic-Jankovic, J.; Bojic, D. The inactivation of escherichia coli by microalloyed aluminium based composite. Facta Univ. Phys. Chem. Technol. 2001, 2, 115-124.

70. Lee, C.; Kim, J.H.; Lee, W.I.; Nelson, K.L.; Yoon, J.; Sedlak, D.L. Bactericidal effect of zero-valent iron nanoparticles on escherichia coli. Environ. Sci. Technol. 2008, 42, 4927-4933.

71. Diao, M.; Yao, M. Use of zero-valent iron nanoparticles in inactivating microbes. Water Res. 2009, 43, 52435251. 
72. Crampon, M.; Joulian, C.; Ollivier, P.; Charron, M.; Hellal, J. Shift in natural groundwater bacterial community structure due to zero-valent iron nanoparticles (nZVI). Front. Microbiol. 2019, 10, 533.

73. Hu, Y.; Wang, J.; Sun, H.; Wang, S.; Liao, X.; Wang, J.; An, T. Roles of extracellular polymeric substances in the bactericidal effect of nanoscale zero-valent iron: Trade-offs between physical disruption and oxidative damage. Environ. Sci. Nano 2019, 6, 2061-2073.

74. Sun, H.; Wang, J.; Jiang, Y.; Shen, W.; Jia, F.; Wang, S.; Liao, X.; Zhang, L. Rapid aerobic inactivation and facile removal of escherichia coli with amorphous zero-valent iron microspheres: Indispensable roles of reactive oxygen species and iron corrosion products. Environ. Sci. Technol. 2019, 53, 3707-3717.

75. You, Y.; Han, J.; Chiu, P.C.; Jin, Y. Removal and inactivation of waterborne viruses using zerovalent iron. Environ. Sci. Technol. 2005, 39, 9263-9269.

76. Ingram, D.T.; Callahan, M.T.; Ferguson, S.; Hoover, D.G.; Shelton, D.R.; Millner, P.D.; Camp, M.J.; Patel, J.R.; Kniel, K.E.; Sharma, M. Use of zero-valent iron biosand filters to reduce E. coli O157:H12 in irrigation water applied to spinach plants in a field setting. J. Appl. Microbiol. 2012, 112, 551-560.

77. Shi, C.; Wei, J.; Jin, Y.; Kniel, K.E.; Chiu, P.C. Removal of viruses and bacteriophages from drinking water using zero-valent iron. Sep. Purif. Technol. 2012, 84, 72-78.

78. Marik, C.M.; Anderson-Coughlin, B.; Gartley, S.; Craighead, S.; Kniel, K.E. The efficacy of zero valent ironsand filtration on the reduction of Escherichia coli and Listeria monocytogenes in surface water for use in irrigation. Environ. Res. 2019, 173, 33-39.

79. Hu, R.; Gwenzi, G.; Sipowo, R.; Noubactep, C. Water treatment using metallic iron: A tutorial review. Processes 2019, 7, 622

80. Tucker, W.G. The purification of water by chemical treatment. Science 1892, 20, 34-38.

81. Mwakabona, H.T.; Ndé-Tchoupé, A.I.; Njau, K.N.; Noubactep, C.; Wydra, K.D. Metallic iron for safe drinking water provision: Considering a lost knowledge. Water Res. 2017, 117, 127-142.

82. Sleiman, N.; Deluchat, V.; Wazne, M.; Mallet, M.; Courtin-Nomade, A.; Kazpard, V.; Baudu, M. Phosphate removal from aqueous solution using ZVI/sand bedreactor: Behavior and mechanism. Water Res. 2016, 99, $56-65$.

83. Gwenzi, W.; Chaukura, N.; Noubactep, C.; Mukome, F.N.D. Biochar-based water treatment systems as a potential low-cost and sustainable technology for clean water provision. J. Environ. Manag. 2017, 197, 732749.

(c) 2020 by the authors. Licensee MDPI, Basel, Switzerland. This article is an open access article distributed under the terms and conditions of the Creative Commons Attribution (CC BY) license (http://creativecommons.org/licenses/by/4.0/). 


\section{Validating the efficiency of the MB discoloration method for the characterization of $\mathrm{Fe}^{0} / \mathrm{H}_{2} \mathrm{O}$ systems using accelerated corrosion by chloride ions}

Raoul Tepong-Tsindéa ${ }^{\mathrm{a}, \mathrm{b}}$, Meghalim Phukan $^{\mathrm{a}}$, Achille Nassi ${ }^{\mathrm{b}}$, Chicgoua Noubactep ${ }^{\mathrm{a}, \mathrm{c}, \mathrm{d}, *}$, Hans Ruppert $^{\mathrm{e}}$

a Department of Applied Geology, Universität Göttingen, Goldschmidtstraße 3, D-37077 Göttingen, Germany

${ }^{b}$ Department of Chemistry, Faculty of Sciences, University of Douala, Cameroon

'Comité Afro-européen, Avenue Léopold II, 41, 5000 Namur, Belgium

${ }^{\mathrm{d}}$ Kultur und Nachhaltige Entwicklung CDD e.V., Postfach 1502, D-37005 Göttingen, Germany

eDepartment of Sedimentology \& Environmental Geology, University of Göttingen, Goldschmidtstraße 3, D-37077 Göttingen, Germany

\section{H I G H L I G H T S}

- Granular metallic iron $\left(\mathrm{Fe}^{0}\right)$ is a powerful material for water treatment.

- Methylene blue (MB) discoloration eases $\mathrm{Fe}^{0}$ testing at lab scale.

- Early MB breakthrough is

documented is systems with large $\mathrm{Cl}^{-}$ levels.

- In the long term, MB discoloration is enhanced in the presence of chloride ions $\left(\mathrm{Cl}^{-}\right)$.

- MB discoloration is recommended for characterizing the effects of $\mathrm{PO}_{4}{ }^{3-}$. $\mathrm{SO}_{4}{ }^{2-}$, etc.

\section{A R T I C L E I N F O}

\section{Article history:}

Received 4 February 2015

Received in revised form 23 April 2015

Accepted 24 April 2015

Available online 15 May 2015

\section{Keywords:}

Aqueous corrosion

Chloride ions

Packed-bed filter

Water treatment

Zero-valent iron
G R A P H I C A L A B S T R A C T

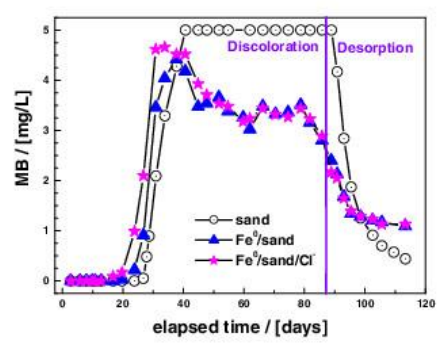

A B S T R A C T

The effect of the chloride ions $\left(\mathrm{Cl}^{-}\right)$on the efficiency of $\mathrm{Fe}^{0}$ /sand systems for methylene blue (MB) discoloration was characterized in column studies for 4 months. Tested systems were: pure sand $\left(0 \% \mathrm{Fe}^{0}-\right.$ reference) and $\mathrm{Fe}^{0} / \mathrm{sand}\left(50 \% \mathrm{Fe}^{0}-\mathrm{vol} / \mathrm{vol}\right)$. Tested $\mathrm{Cl}^{-}$concentrations were $0.0,2.1,21.1$ and $42.2 \mathrm{mM}$. The used $\mathrm{MB}$ concentration was $16 \mu \mathrm{M}\left(5 \mathrm{mg} \mathrm{L}^{-1}\right)$ and used $\mathrm{Fe}^{0}$ mass was $100 \mathrm{~g}$. Discoloration experiments lasted for 89 days and was followed by a 26 days desorption experiment. Each system was characterized by the time-dependent changes of the $\mathrm{pH}$ value, the iron breakthrough, the MB breakthrough, and the hydraulic conductivity (permeability). During the discoloration experiments, a total of $17.4 \mathrm{~L}$ (184 pore volumes) of the MB solution flowed through each column $(279.0 \mu \mathrm{M}$ dye or $87.2 \mathrm{mg})$. No significance changes in $\mathrm{pH}$ value and permeability could be documented. Discoloration and desorption results confirmed that sand is an excellent MB adsorbent (only $11 \%$ desorption in the reference system). In the absence of $\mathrm{Cl}^{-}, 15 \mathrm{mg} \mathrm{MB}$ was discolored. Up to $18 \mathrm{mg}$ of $\mathrm{MB}$ was discolored in the presence of $\mathrm{Cl}^{-}$. The same trend was observed in changes of the extent of iron release which was $7.3 \mathrm{mg}$ at $0.0 \mathrm{mM} \mathrm{Cl}^{-}$and $16.2 \mathrm{mg}$ at $42.2 \mathrm{mM} \mathrm{Cl}^{-}$. These results confirm that chloride ions enhance the kinetics of $\mathrm{Fe}^{0}$ corrosion and thus the production of contaminant collectors (for MB co-precipitation). Results confirmed the suitability of $\mathrm{MB}$ as a powerful operative indicator for the characterization of processes in the $\mathrm{Fe}^{0} / \mathrm{H}_{2} \mathrm{O}$ system. (c) 2015 Elsevier B.V. All rights reserved.

* Corresponding author at: Department of Applied Geology, Universität Göttingen, Goldschmidtstraße 3, D-37077 Göttingen, Germany. Tel.: +49 5513933191 ; fax: +49 551399379.

E-mail address: cnoubac@gwdg.de (C. Noubactep).

http://dx.doi.org/10.1016/j.cej.2015.04.129

1385-8947/으 2015 Elsevier B.V. All rights reserved. 


\section{Introduction}

Metallic iron $\left(\mathrm{Fe}^{0}\right)$ has been introduced as reactive material for environmental remediation [1,2]. During the past two decades, water filtration through packed beds containing $\mathrm{Fe}^{0}$ ( $\mathrm{Fe}^{0}$ filters) has developed to an established remediation technology for both in situ permeable reactive barriers (PRBs) [1-6] and above ground reactors $[7,8]$. Contaminant removal in $\mathrm{Fe}^{0}$ filters is mediated by aqueous iron corrosion which kinetic is typically low under environmental conditions $(\mathrm{pH}>4.5)$ [9,10]. Several attempts were focused at improving the rates of these processes to: (i) reduce the remediation time and (ii) increase the cost-effectiveness of the technology [2-4].

Despite 20 years of intensive research, the exact mechanisms responsible for contaminant removal in $\mathrm{Fe}^{0}$ filters is still not established $[2,11]$. This frustrating situation complicates efforts to properly design $\mathrm{Fe}^{0}$-based systems [11]. The effective design and operation of $\mathrm{Fe}^{0}$ filters would be greatly improved by a more detailed, process-level understanding of the mechanisms (adsorption, chemical reaction, co-precipitation, size-exclusion) by which aqueous contaminants are removed. Furthermore, increasing the kinetics of these processes would extend the applicability of $\mathrm{Fe}^{0}$ filters by decreasing the remediation time. Progress in understanding the relative importance of key operational parameters (particle size and particle size distribution, particle shape, thickness of the filter, water flow velocity) was also not satisfactorily $[12,13]$. For example, it is still not established that pure $\mathrm{Fe}^{0}$ filters $\left(100 \% \mathrm{Fe}^{0}\right)$ are not sustainable [13] because volumetric expansion of all $\mathrm{Fe}^{0}$ particles implies that complete clogging is just a matter of time. The acceptance of this evidence is delayed by the slowness of iron corrosion and the shortness of laboratory experiments [8,9,14].

Owing to the slowness of aqueous iron corrosion under environmental conditions $[8,9]$, some tools have been applied to get reliable results at relative short experimental durations [2]. These tools expand from shaking batch experiments, using multi-metallic systems, using nano-scale $\mathrm{Fe}^{0}$ materials, increasing the flow velocity in column experiments and using rapid small scale column tests (RSSCTs) $[1,2,15]$. RSSCT is an established tool for the design of packing beds containing inert or less reactive adsorbents [16]. In RSSCTs, small columns are loaded with grounded adsorbents ( $\mu \mathrm{m}$-sized particles). This simulates the performance of a pilot or a full scale system. The similarity of mass transfer processes and hydrodynamic characteristics between the two columns imply similarities in the breakthrough curves. Due to its small size, the RSSCT requires a fraction of the time and water volume compared to pilot columns $[15,16]$.

The suitability of RSSCT for the investigation of the $\mathrm{Fe}^{0} / \mathrm{H}_{2} \mathrm{O}$ system has been questioned due to two major interrelated factors: (i) $\mu \mathrm{m}$-size particles corrode with a higher kinetic, and (ii) the smaller pore spaces (inter-particle voids or bed porosity) are quickly filled by iron oxides (corrosion products). Each iron oxide molecule (e.g. $\mathrm{Fe}_{3} \mathrm{O}_{4}$ ) occupies the same volume; either it results from a $\mu \mathrm{m}$ or $\mathrm{mm} \mathrm{Fe}{ }^{0}$ parent. Therefore, there is still a need to properly shorten the experimental duration while still achieving reliable results. The use of methylene blue (MB) as an operation indicator has been recently introduced [17]. The idea is to exploit the low affinity of $\mathrm{MB}$ (cationic) for iron oxides (positively charged at $\mathrm{pH}>6.0$ ) to characterize the evolution of processes in $\mathrm{Fe}^{0} / \mathrm{H}_{2} \mathrm{O}$ systems. First results of the $\mathrm{MB}$ discoloration method have fixed the discussion on the suitability of mixing $\mathrm{Fe}^{0}$ with non-expansive aggregates (including sand) for sustainable $\mathrm{Fe}^{0}$ filters [17] and demonstrated the ion-selective nature of $\mathrm{Fe}^{0} / \mathrm{H}_{2} \mathrm{O}$ systems [18]. The suitability of $\mathrm{MB}$ discoloration to characterize the impact of various ubiquitous species on the efficiency of $\mathrm{Fe}^{0}$ filters is yet to be established.

The present study aims at investigating the suitability of the MB discoloration method to characterize the effects of chloride ions on the efficiency of $\mathrm{Fe}^{0} / \mathrm{H}_{2} \mathrm{O}$ systems for contaminant removal. The chloride ion is selected because it is univocally reported that its presence accelerates $\mathrm{Fe}^{0}$ corrosion by retarding the formation the oxide scale on $\mathrm{Fe}^{0}$ [19]. MB discoloration is investigated in four systems differing by the $\mathrm{Cl}^{-}$concentration: $0.0,2.1,21.1$ and $42.2 \mathrm{mM}$. The experiments were performed in duplicates. An accompanying experiment with sand alone $\left(0 \% \mathrm{Fe}^{0}\right)$ was performed to account for quantitative MB adsorptive discoloration by sand [17,18]. The systems are mainly characterized by the extent of iron breakthrough, MB breakthrough and the evolution of the $\mathrm{pH}$ values. The results are comparatively discussed.

\section{Background of the experimental methodology}

\subsection{Working hypothesis}

The two universal separation mechanisms of filtration systems are (i) steric hindrance ( size-exclusion or straining) and (ii) electrostatic interactions (attraction or repulsion). When a solution flows through a fixed bed of granular particles, there is adsorptive filtration for dissolved species experiencing electrostatic attractions with fixed particles. On the contrary, dissolved species experiencing electrostatic repulsions to fixed particles are rejected (charge exclusion) and are practically not retarded in the fixed bed. A particular case of charge exclusion is the Donnan exclusion, which is generally described as the decrease of the concentration of mobile ions within an ion exchange membrane due to the presence of fixed ions of the same sign as the mobile ions.

MB (size: about $15 \AA$ ) discoloration through a filter containing $\mathrm{Fe}^{0}$ and sand particles of $\mathrm{mm}$ size is primarily not a size-exclusion process. In fact the inter-granular spaces between $\mathrm{Fe}^{0}$ and/or sand particles (bed porosity) are necessarily in the order of $\mathrm{mm}$. This evidence reveals the paramount importance of electrostatic interactions for the process of MB discoloration with granular particle of $\mathrm{mm}$ size. It has already been demonstrated that cationic MB readily adsorbs onto negatively charged sand particles, but is repulsed by the positively charged iron oxide surface [20]. When $\mathrm{Fe}^{0}$ is mixed to sand, $\mathrm{Fe}^{0}$ is corroded by inflowing water and resulting $\mathrm{Fe}^{2+}$ and $\left(\mathrm{Fe}^{3+}\right)$ compete with MB for adsorption onto sand [17]. When enough $\mathrm{Fe}^{0}$ is dissolved, all sand particles are in situ coated by iron oxides. From this time on the whole $\mathrm{Fe}^{\%} /$ sand mixture (and possibly the sand layer downwards) rejects MB (charge exclusion, ion-selectivity) resulting in an 'early' breakthrough.

The methodology used herein consists in following the extent of $\mathrm{MB}$ discoloration in a "sand- $\mathrm{Fe}^{\mathrm{O}} /$ sand-sand" system by varying the concentration of chloride ions $\left(\mathrm{Cl}^{-}\right)$of the inflowing solution. The two working hypothesis are the following: (i) 'Because $\mathrm{Cl}^{-}$accelerates iron corrosion early MB breakthrough is observed in the presence of $\mathrm{Cl}^{-}$' (Assumption 1), and (ii) 'the higher the $\mathrm{Cl}^{-}$ concentration, the earlier the MB breakthrough' (Assumption 2). The validity of both Assumptions is discussed while keeping in mine the suitability of the MB discoloration method to characterize the reactivity of $\mathrm{Fe}^{0} / \mathrm{H}_{2} \mathrm{O}$ systems.

\subsection{MB breakthrough from a $\mathrm{Fe}^{0} /$ sand system}

When a MB solution is pumped into a column containing a reactive zone (RZ) of $\mathrm{Fe}^{0}$ and sand, MB discoloration occurs preponderantly in the $R Z$ entrance but there is no discoloration front comparable to the adsorption front observed in a pure sand system $[17,18] . \mathrm{H}_{2} \mathrm{O}\left(\mathrm{H}^{+}\right)$is corrosive for $\mathrm{Fe}^{0}$ and iron corrosion products inhibit MB discoloration by sand (Section 2.1). The extend of inhibition depends on the intrinsic reactivity of the used $\mathrm{Fe}^{0}$ material or the kinetics of iron corrosion under operational conditions. 

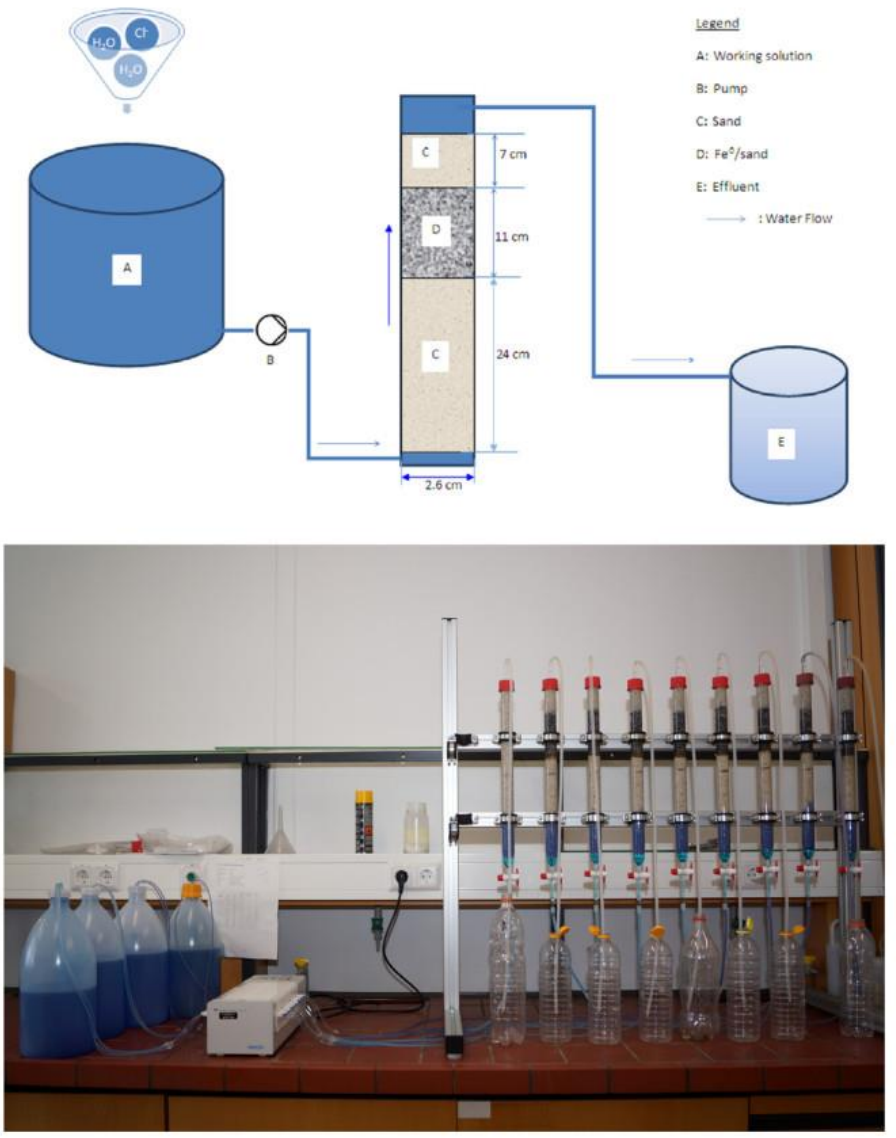

Fig. 1. (a) Schematic diagram of the design of a $\mathrm{Fe}^{0}$-based column. The reference system was made of sand alone. (b) Photograph of the design of column experiments. Working solution are stocked in $5 \mathrm{~L}$ polypropylene bottles. Tubing materials are in polypropylene (PP) and polyethylene terephthalate (PET). The samples were collected in PET bottles. The first column left is the reference system (sand alone). The eight other column are duplicates of the tested chloride concentrations. The columns were fed with a $5.0 \mathrm{mg} \mathrm{L}^{-1}$ methylene blue (MB) solution. Tested chloride concentrations were $0.0,7.5,750$ and $1500 \mathrm{mg} \mathrm{L}^{-1}$. It is evident that MB adsorption by bottle and tube materials was significant (blue color). (For interpretation of the references to color in this figure legend, the reader is referred to the web version of this article.)

Accordingly to Alamilla et al. [10], the function describing instantaneous rate of iron corrosion is expressed as follows:

$$
v(t)=v_{P}+\left(v_{0}-v_{P}\right)^{*} \exp \left(-q_{0}^{*} t\right)
$$

where $q_{0}$ is a constant, $v_{0}$ is the short-term and $v_{p}$ the long-term average rate of $\mathrm{Fe}^{0}$ corrosion. It can be seen that instantaneous rate drops exponentially from $v_{0}$ to $v_{\mathrm{p}} \quad v_{0}>v_{\mathrm{p}}$. Consequently, $v_{\mathrm{p}} \leqslant v(t) \leqslant v_{\mathrm{p}}$. The form of Eq. (1) allows relating the instantaneous rate, $v(t)$ to the average rate $\left(v_{P}\right)$. " $v_{0}$ " is associated to laboratory measurements while " $v_{P}$ " can be directly associated with the field measurements [10].

The form of Eq. (1) suggests that the contaminant breakthrough from a $\mathrm{Fe}^{\mathrm{O}}$-containing column will possibly have a S-shape but the effluent contaminant concentration remains lower than the influent concentration $\left(C / C_{0}<1\right)$ until the used $\mathrm{Fe}^{0}$ is exhausted, assuming that the column is designed to avoid clogging [17,18]. In other words, a $\mathrm{Fe}^{0}$ filter can be designed to achieve a certain level of contaminant mitigation in the long-term [1,2]. All is needed are the $v_{0}$ and $v_{p}$ values. For example a filter can be designed such that a $60 \%$ breakthrough for a named contaminant corresponds to values bellow the maximum contamination level (MCL).

In the present study, the $\mathrm{Fe}^{0}$ /sand zone (RZ) is sandwiched between two sand layers: $H_{\text {sand }, 1}=24 \mathrm{~cm}$ and $H_{\text {sand }, 2}=7 \mathrm{~cm}$ (Fig. 1a). This means that the MB solution ([MB $\left.]_{0}=5 \mathrm{mg} \mathrm{L}^{-1}\right)$ is first adsorptive discolored in the $H_{\text {sand, } 1}$ layer $(24 \mathrm{~cm})$ prior to enter the RZ. Here, a clear adsorption front can be observed (Fig. 1b). Selecting these values of $H_{\mathrm{sand}, 1}$ and [MB] $]_{0}$ aimed at better characterizing the effect of chloride concentrations $(0.0,7.5,750$ and $1500 \mathrm{mg} \mathrm{L}^{-1}$ ) on the efficiency of the $\mathrm{Fe}^{0} / \mathrm{H}_{2} \mathrm{O}$ system.

It should be recalled that the most efficient system is operatively the one in which $\mathrm{Fe}^{0}$ corrodes intensively. Intensive $\mathrm{Fe}^{0}$ corrosion is coupled with: (i) more $\mathrm{Fe}^{2+}$ and $\mathrm{Fe}^{3+}$ ions for inhibiting MB adsorptive discoloration by sand (Assumption 1), (ii) more iron hydroxides to in situ coat the sand surface and thus inhibiting MB adsorptive discoloration by sand (Assumption 1), (iii) more iron hydroxides for MB co-precipitation, and (iv) more iron oxides MB discoloration by size-exclusion. Summarizes, early MB breakthrough is observed until the surface of sand is completely coated with iron oxides, afterwards increased $\mathrm{MB}$ discoloration is expected due to $\mathrm{MB}$ co-precipitation and improved size-exclusion (Assumption 3). 


\section{Materials and methods}

\subsection{Solutions}

\subsubsection{Methylene blue}

Methylene blue (MB) is widely used as model contaminant to characterize the suitability of various systems for water treatment [21]. MB used herein was of analytical grade and is selected for its differential affinity to sand and iron oxides [17]. The working solution has a molar concentration of $15.8 \mu \mathrm{M}\left(5 \mathrm{mg} \mathrm{L}^{-1}\right)$ and was weekly prepared by diluting a 200 fold concentrated stock solution $(3150 \mu \mathrm{M})$ using the tap water of the city of Göttingen. Its average composition (in $\mathrm{mg} \mathrm{L}^{-1}$ ) was: $\mathrm{Cl}^{-}: 12.9 ; \mathrm{NO}_{3}^{-}: 7.5 ; \mathrm{SO}_{4}^{2-}: 35.5 ; \mathrm{Na}^{+}$; 9.7; $\mathrm{K}^{+}: 0.9 ; \mathrm{Mg}^{2+}: 8.2 ; \mathrm{Ca}^{2+}: 37.3$. The $\mathrm{pH}$ value of the initial solution was 8.2. The used initial concentration $\left(5 \mathrm{mg} \mathrm{L}^{-1}\right)$ was selected to approach the concentration range of natural waters (MB as model micro-pollutant)

\subsubsection{Iron}

A standard iron solution ( $1000 \mathrm{mg} \mathrm{L}^{-1}$ ) from Baker $\mathrm{JT}^{\circledR}$ was used to calibrate the spectrophotometer used for analysis. All other chemicals used were of analytical grade. In preparation for spectrophotometric analysis, ascorbic acid was used to reduce $\mathrm{Fe}^{\mathrm{III}}$ in solution to $\mathrm{Fe}^{\mathrm{II}}$. 1,10 orthophenanthroline was used as reagent for $\mathrm{Fe}^{\mathrm{II}}$ complexation. Other chemicals used in this study included $\mathrm{L}(+)$-ascorbic acid and $\mathrm{L}$-ascorbic acid sodium salt.

\subsubsection{Chloride}

The selected chloride salt was commercial cooking salt $(\mathrm{NaCl})$. Table salt was used to mimic the characteristic elevated salt levels of costal cities like Douala (Cameroon). Four different $\mathrm{NaCl}$ concentrations were tested: $0.0,7.5,750$ and $1500 \mathrm{mg} \mathrm{L}^{-1}$. The stock solution was prepared by dissolving $247.2 \mathrm{~g}$ of $\mathrm{NaCl}$ in $1.0 \mathrm{~L}$ tap water. The working solutions were prepared by diluting $0.0,2.5,25.0$ and $50.0 \mathrm{~mL}$ of the stock solution in $5 \mathrm{~L}$ water containing already $25 \mathrm{~mL}$ of the MB stock solution (Section 3.1.1).

\subsection{Solid materials}

3.2.1. Metallic iron $\left(\mathrm{Fe}^{0}\right)$

The used $\mathrm{Fe}^{0}$ material was purchased from iPutech (Rheinfelden, Germany). The material is available as fillings with a particle size between 0.3 and $2.0 \mathrm{~mm}$. Its elemental composition as specified by the supplier was: C: $3.52 \%$; $\mathrm{Si}: 2.12 \%$; $\mathrm{Mn}$ : $0.93 \%$; $\mathrm{Cr}$ : $0.66 \%$. The material was used without any further pre-treatment. $\mathrm{Fe}^{0}$ was proven a powerful discoloration agent for MB with the particularity, that discoloration agents are progressively generated in situ [22]. Therefore, the discoloration capacity of used $\mathrm{Fe}^{0}$ cannot be exhausted within the experimental duration ( 4 months).

\subsubsection{Sand}

The used sand was a commercial material for aviculture ("Papagaiensand" from RUT - Lehrte/Germany). Papagaiensand was used as received without any further pre-treatment or characterization. The particle size was between 0.5 and $2.0 \mathrm{~mm}$. Sand was used because of its worldwide availability and its use as admixing agent in $\mathrm{Fe}^{0} / \mathrm{H}_{2} \mathrm{O}$ systems [23].

\section{3. $M B$ discoloration}

\subsubsection{Batch experiments}

Batch experiments shaken at $75 \mathrm{rpm}$ were performed in essay tubes for an experimental duration of 14 days. The batches consisted of 0.0 or $0.4 \mathrm{~g}$ of sand, 0.0 or $0.1 \mathrm{~g}$ of $\mathrm{Fe}^{0}$ and mixtures thereof in $22.0 \mathrm{~mL}$ of a $31.5 \mu \mathrm{M}$ dye solution. The experiments were performed under the laboratory desk to protect MB from direct sunlight. The efficiency of individual systems for MB discoloration was characterized at laboratory temperature (about $22 \pm 4{ }^{\circ} \mathrm{C}$ ). Initial $\mathrm{pH}$ was $\sim 8.2$. After equilibration, up to $3.0 \mathrm{~mL}$ of the supernatant solutions were carefully retrieved (no filtration) for immediate MB measurements (no dilution). Each experiment was performed in triplicates, averaged values are presented. The operational reference was the MB concentration of the essay tube containing no additives $\left(0.0 \mathrm{~g}\right.$ sand and $\left.0.0 \mathrm{~g} \mathrm{Fe}^{0}\right)$.

\subsubsection{Column experiments}

As-received $\mathrm{Fe}^{0}$ from iPutec $\mathrm{GmbH}$ (Rheinfelden, Germany) was used. The materials were packed into columns in a dual manner. Sand layers $\left(H_{\mathrm{sand}, 1}=24.0 \mathrm{~cm}\right.$ and $\left.H_{\mathrm{sand}, 2}=7.0 \mathrm{~cm}\right)$ were wet packed (Table 1$)$. For reactive layers $\left(H_{R z}=11 \mathrm{~cm}\right)$ (Fig. 1a), dry homogenized $\mathrm{Fe}^{0}$ :sand mixtures $(1: 1(\mathrm{vol} / \mathrm{vol}))$ were introduced into the column in small lofts (about $2 \mathrm{~cm}$ each), which were wetted and compacted with manual tapping. To warrant optimal compaction, columns were gently tapped with a $100 \mathrm{~mL}$ PET flacon containing water. The reactive zone was built while using the volume occupied by $100 \mathrm{~g}$ of $\mathrm{Fe}^{0}(32 \mathrm{~mL}$ - apparent volume) as unity. The resulting sand mass is $48 \mathrm{~g}$ (weight ratio $32.5 \%$ ).

The $15.8 \mu \mathrm{M}$ MB solution was pumped upwards from PE bottles using a peristaltic pump (Ismatec, ICP 24). Tygon tubes were used to connect inlet reservoir, pump, column and outlet. Nine glass columns (42 cm long, $2.6 \mathrm{~cm}$ inner diameter) having a section of $5.31 \mathrm{~cm}^{2}$ were used. The pore volume of the columns was determined as $95 \mathrm{~mL}$ using a concentrated $\mathrm{NaCl}$ solution (results not shown). The columns were mostly packed with sand (Table 1 , Fig. $1 \mathrm{a}$ and b). The experiment lasted for 62 days, corresponding to $16.8 \mathrm{~L}$ or $117 \mathrm{PV}$ of the MB solution. The extent of MB discoloration as impacted by individual chloride levels was the major target. The experiments were performed in duplicates at room temperature $\left(22 \pm 3{ }^{\circ} \mathrm{C}\right)$. A stable flow rate of $0.1 \mathrm{~mL} \mathrm{~min}^{-1}$ was maintained throughout the experiment. The $\mathrm{Fe}^{0}$-free system (reference) contained $360 \mathrm{~g}$ of sand.

The whole effluent was collected. The volume recorded as function of the elapsed time served for the assessment of flow velocity or hydraulic conductivity. Each collected fraction was analysed for $\mathrm{MB}$ and dissolved $\mathrm{Fe}$. The $\mathrm{pH}$ value of the effluent was measured once a week.

\section{Table 1}

Summary of the experimental set up of the column experiments and the distribution of discolored methylene blue (MB). $\left[\mathrm{Cl}^{-}\right]$is the chloride concentration of the influent MB solution. $H_{\text {sand,1 }}$ is the height of sand preceding the $\mathrm{Fe}^{0} /$ sand layer. $\mathrm{MB}_{\text {tot }}$ is the total amount of $\mathrm{MB}$ discolored in the column, $\mathrm{MB}_{\text {sand }}$ the fraction discolored by sand and $\mathrm{MB}_{\mathrm{ZV}}$ the fraction discolored after $H_{\text {sand,1 }}$.

\begin{tabular}{|c|c|c|c|c|c|c|}
\hline Column & Material & $\begin{array}{l}{\left[\mathrm{Cl}^{-}\right]} \\
(\mathrm{mg} / \mathrm{L})\end{array}$ & $\begin{array}{l}H_{\text {sand, } 1} \\
(\mathrm{~cm})\end{array}$ & $\begin{array}{l}\mathrm{MB}_{\text {tot }} \\
(\mathrm{mg})\end{array}$ & $\begin{array}{l}\mathrm{MB}_{\text {sand }} \\
(\mathrm{mg})\end{array}$ & $\begin{array}{l}\mathrm{MB}_{\mathrm{ZV} \mid} \\
(\mathrm{mg})\end{array}$ \\
\hline 1 & Sand & 0.0 & 40.0 & 79.8 & 79.8 & 0.0 \\
\hline 2 & $\begin{array}{l}\mathrm{Fe}^{0} / \\
\text { sand }\end{array}$ & 0.0 & 24.0 & 60.1 & 45.6 & 14.5 \\
\hline 3 & $\begin{array}{l}\mathrm{Fe}^{0} / \\
\text { sand }\end{array}$ & 0.0 & 24.0 & 61.2 & 45.6 & 15.6 \\
\hline 4 & $\begin{array}{l}\mathrm{Fe}^{0} / \\
\text { sand }\end{array}$ & 75 & 24.0 & 64.0 & 45.6 & 18.4 \\
\hline 5 & $\begin{array}{l}\mathrm{Fe}^{0} / \\
\text { sand }\end{array}$ & 75 & 24.0 & 62.9 & 45.6 & 17.4 \\
\hline 6 & $\begin{array}{l}\mathrm{Fe}^{0} / \\
\text { sand }\end{array}$ & 750 & 24.0 & 60.6 & 45.6 & 15.0 \\
\hline 7 & $\begin{array}{l}\mathrm{Fe}^{0} / \\
\text { sand }\end{array}$ & 750 & 24.0 & 63.3 & 45.6 & 17.7 \\
\hline 8 & $\begin{array}{l}\mathrm{Fe}^{0} / \\
\text { sand }\end{array}$ & 1500 & 24.0 & 60.8 & 45.6 & 15.2 \\
\hline 9 & $\begin{array}{l}\mathrm{Fe}^{0} l \\
\text { sand }\end{array}$ & 1500 & 24.0 & 65.8 & 45.6 & 20.2 \\
\hline
\end{tabular}




\subsection{Intermittent filtrations}

After 62 days of continuous filtration, an intermittent filtration was initiated for 6 weeks (02.10.-24.11.2014). During this time, variable stop durations lasting from 2 to 9 days were tested. After each stop, about $12 \mathrm{PV}$ of MB $(1.2 \mathrm{~L})$ were allowed to filter continuously like in Section 3.3.2 The idea was to test the possibility of optimising $\mathrm{Fe}^{0}$ filter performance by alternating filtration and resting times. It was speculated that during the (long) stops iron corrosion products could accumulate in the inter-particle space, reduce the porosity and thus the permeability and improve MB discoloration by size-exclusion (Assumption 3 ). The intermittent filtration experiment lasted for a total of 54 days with 27 days of filtration.

\subsection{Desorption experiments}

After intermittent filtrations (in total 89 days of filtration or 116 days of column operation), each column was washed with the tap water of the city of Göttingen (operational solvent) in order to assess the extent of irreversible removal. The flow rate and all other parameters of the discoloration experiment were maintained. Only the feeding solutions were replaced by tap water. Each column was washed with $6.71 \mathrm{~L}$ water (70.6 PV).

3.6. Compaction of the column material

Three weeks after the end of the desorption experiments (break due to Christmas holidays), the columns were characterized by visual observations and the extent of the compaction of material within the reactive zone [24]. As the columns had operated in an up flow mode with a $H_{\text {sand, } 1}$ of $24 \mathrm{~cm}$ (blue in color), the challenge was reduced to observe the reactive zone $(11 \mathrm{~cm})$ and $H_{\mathrm{sand}}$ $(7 \mathrm{~cm})$. In particular, the ease with which the reactive zone would remove from the column was described.

\subsection{Analytical methods}

MB and aqueous iron concentrations were determined by a Cary 50 UV-vis spectrophotometer (Varian). The working wavelength for $M B$ was $664.5 \mathrm{~nm}$. Dissolved iron was determined at $510 \mathrm{~nm}$. Cuvettes with $1.0 \mathrm{~cm}$ light path were used. The iron determination followed the 1,10 orthophenanthroline method [25]. The spectrophotometer was calibrated for $\mathrm{MB}$ and iron concentrations $\leqslant 10.0 \mathrm{mg} \mathrm{L}^{-1}$. The $\mathrm{pH}$ value was measured by combined glass electrodes (WTW Co., Germany).

\subsection{Presentation of experimental results}

The MB breakthrough curves are expressed in terms of normalized concentration defined as the ratio of effluent dye concentration to inlet dye concentration $\left(C / C_{0}\right)$ as a function of time. For each column set-up, the extent of dye discoloration (efficiency, $E$ in \%) at each time was calculated according to the following equation (Eq. (2)):

$E=\left[\left(\sum V_{i}^{*} C_{0}-\sum V_{i}^{*} C_{i}\right) / \sum V_{i}^{*} C_{0}\right]^{*} 100 \%$

BT $(\%)=100-E$

where $C_{0}$ is the initial MB concentration $\left(5 \mathrm{mg} \mathrm{L}^{-1}\right)$, while $C_{i}$ gives the corresponding MB concentration of the sample collected $V_{i}$ at $t_{i}$. This means that at any time the $E$ value is related to the total amount of dye which has flowed through the column. With increasing experimental duration $C_{0}$ needed corrections to account for adsorption on PE bottles and possible biodegradation/photodegrada tion. To this end, the dye concentration of the reference system (100\% sand) was set to $100 \%\left(5 \mathrm{mg} \mathrm{L}^{-1}\right)$ and the concentrations of the effluent from other systems were corrected accordingly. BT (Eq. (3)) corresponds to the cumulative extent of dye breakthrough.

The extent of MB discoloration ( $m_{\mathrm{MB}}$ in $\mathrm{mg}$ ) within the reactive zone was calculated from $H_{\mathrm{s} a n d, 1}(24 \mathrm{~cm})$ using the rule of proportion. In this effort, the pure sand system $\left(0 \% \mathrm{Fe}^{0}\right)$ was used as reference ( $42 \mathrm{~cm}$ of sand for $79.8 \mathrm{mg} \mathrm{MB}$ ) (Eq. (3)). $79.8 \mathrm{mg}$ is the value of $m_{\text {discol }}\left(m_{\mathrm{discol}}=\Sigma V_{i}{ }^{*} C_{0}\right)$ at MB breakthrough in the pure sand column $[17,18]$ :

$m_{\mathrm{MB}}(\mathrm{mg})=\left(H_{\text {sand }, 1} / 42\right)^{*} 79.8$

The mass of $\mathrm{MB}$ removed by $H_{\mathrm{sand}, 1}=24 \mathrm{~cm}$ is $45.6 \mathrm{mg}$. Subtracting $45.6 \mathrm{mg}$ from the total mass of discolored MB gives the $\mathrm{MB}$ mass which discoloration is related to $\mathrm{Fe}^{0}$ (Table 1 ).

\section{Results and discussion}

\subsection{Rationale for the selection of tested $\mathrm{Cl}^{-}$concentrations}

Fig. 2 summarizes the results of the batch experiments with $\mathrm{Cl}^{-}$ concentration varying from 0 to $1000 \mathrm{mg} \mathrm{L}^{-1}$ in the pure sand and the $\mathrm{Fe}^{\mathrm{0}} / \mathrm{sand}$ systems. It can be seen that the pure sand system exhibited no significant change in the extent of $\mathrm{MB}$ discoloration as the $\mathrm{Cl}^{-}$concentration varied, the $E$ value was constant at $22 \pm 4 \%$. In the $\mathrm{Fe}^{0}$ /sand system on the contrary, there was a trend for decreasing $E$ value with increasing $\mathrm{Cl}^{-}$concentration (Assumption 2 is validated). The maximal $E$ value was $44 \pm 3 \%$ at $25 \mathrm{mg} \mathrm{L}^{-1} \mathrm{Cl}^{-}$. This value decreased to $28 \pm 5 \%$ at $1000 \mathrm{mg} \mathrm{L}^{-1}$ $\mathrm{Cl}^{-}$. This behavior is justified by the increased solubility of iron in the presence of $\mathrm{Cl}^{-}$as $\mathrm{FeCl}_{2}$ and $\mathrm{FeCl}_{3}$ are more soluble than the corresponding hydroxides. Less hydroxide precipitation means less opportunity for MB co-precipitation. A closed consideration of Fig. 2 suggests that the trend for MB discoloration could not be monotone at $\left[\mathrm{Cl}^{-}\right]<250 \mathrm{mg} \mathrm{L}^{-1}$. For this reason the concentration to be tested in column experiments were the following: $0.0,7.5$, 75,750 and $1500 \mathrm{mg} \mathrm{L}^{-1}$ corresponding to $0.0,2.1,21.1$ and $42.2 \mathrm{mM}$.

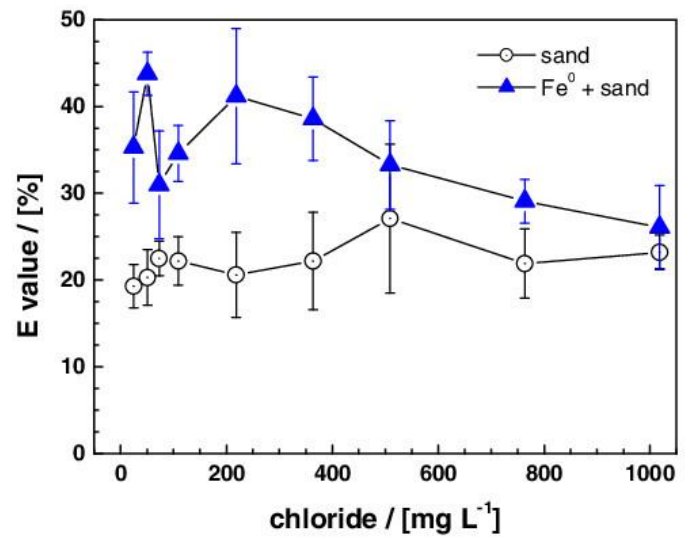
Fig. 2. Comparison of the efficiency of tested pure sand and $\mathrm{Fe}^{0} / \mathrm{sand}$ systems for
methylene blue (MB) discoloration for 14 days as function of the chloride concentration. The lines are not fitting functions, they simply connect points to facilitate visualization. 


\subsection{Validation of the experimental methodology}

Table 2 presents the MB breakthrough for reference system (0) and the mean value of each duplicate for the $\mathrm{Fe}^{0}$-based systems ( $\mathrm{I}$, II, III and IV) for the first 29 days of the experiment. During this time, a total of $8.2 \mathrm{~L}$ (86.3 PV) of MB flowed through each column. Data in Table 2 reveal that the earliest breakthrough was observed at day 17 in system IV ( $\mathrm{Fe}^{0} /$ sand, $\left.\mathrm{Cl}^{-}: 1500 \mathrm{mg} \mathrm{L}^{-1}\right)$ and the latest at day 27 in system 0 (sand, $\mathrm{Cl}^{-}: 0 \mathrm{mg} \mathrm{L}^{-1}$ ). The three other $\mathrm{Fe}^{0} /$ sand systems (I, II and III) all experienced a breakthrough three days after system IV (day 20). These results clearly validate Assumption 1 as early breakthrough is documented in the $\mathrm{Cl}^{-}$richest system. The lack of differential behavior in the three other systems (I, II and III) could be attributed to the high of $H_{\text {sand1 }}(24 \mathrm{~cm})$ in relation to the initial MB concentration and the tested flow velocity. Varying one of these parameters (or using a less reactive $\mathrm{Fe}^{0}$ material) would enable a proper testing of Assumption 2. In should be recalled that the operational solvent is tap water with $13 \mathrm{mg} \mathrm{L}^{-1} \mathrm{Cl}^{-}$. In other words, under the experimental conditions of this work, there was no significant impact of $\mathrm{Cl}^{-}$on the kinetic of in situ coating sand in the $\mathrm{RZ}$ and in $\mathrm{H}_{\mathrm{sand} 2}$ as the $\mathrm{Cl}^{-}$concentration varies from 13 to $750 \mathrm{mg} \mathrm{L}^{-1}$. It should be recalled here that Assumption 2 was validated in batch systems (Section 4.1).

The fact that the reference system experienced the latest breakthrough confirms the evidence that sand is a good adsorbent for MB $[18,19,26]$. The fact that the $\mathrm{Fe}^{0} /$ sand system fed by the largest concentration of chlorine $\left(1500 \mathrm{mg} \mathrm{L}^{-1}\right)$ experienced the earliest breakthrough confirms the evidence that $\mathrm{Cl}^{-}$ions accelerate corrosion (Section 4.1 and Assumption 1) [19]. During the 16 first days of the experiments, MB was quantitatively discolored within $H_{\text {sand } 1}$ $(24 \mathrm{~cm})$ and $\mathrm{Fe}^{\mathrm{II}}, \mathrm{Fe}^{\mathrm{III}}$ from the reactive zone have been quantitatively adsorbed onto sand in the reactive zone and in the $H_{\text {sand2 }}$ layer $(7 \mathrm{~cm}$ ), disfavoring MB adsorption (Section 2.1). The fact that systems I $\left(\mathrm{Cl}^{-}: 0.0 \mathrm{mg} \mathrm{L}^{-1}\right)$, II $\left(\mathrm{Cl}^{-}: 7.5 \mathrm{mg} \mathrm{L}^{-1}\right)$ and III $\left(\mathrm{Cl}^{-}\right.$: $750 \mathrm{mg} \mathrm{L}^{-1}$ ) all experienced breakthrough at day 20 suggests that tap water (operational solvent) could quantitatively leached $\mathrm{Fe}^{\mathrm{II}} / \mathrm{Fe}^{\mathrm{III}}$ species for coating sand in the reactive zone and in $H_{\text {sand2 }}$ layer. Fig. 3 shows clearly the absence of a blue coloration in the $H_{\mathrm{sand} 2}$ layer but blue coloration of the tubing material. A brownish coloration of the tubing material is also observed in all $\mathrm{Fe}^{0}$-based systems.

The results presented in Table 2 can be summarized in one sentence. In the medium-term, the whole zone downwards from a reactive zone ( $\mathrm{Fe}^{0} /$ sand) is an iron oxide coated system (Fig. 3). Accordingly, after the exhaustion of the adsorption capacity of

Table 2

Comparison of the extent of MB discoloration by sand (system 0) and the four investigated $\mathrm{Fe}^{0}$-based systems (I through IV) for the first 29 days. Experiments pertaining to systems I $\left(0.0 \mathrm{mg} \mathrm{L}^{-1} \mathrm{Cl}^{-}\right)$through IV $\left(1500 \mathrm{mg} \mathrm{L}^{-1} \mathrm{Cl}^{-}\right)$were performed in duplicates, mean values are given.

\begin{tabular}{cllllll}
\hline$t$ (day) & $V(\mathrm{~L})$ & \multicolumn{2}{l}{$\left.\mathrm{MB}^{2} \mathrm{mg} \mathrm{L}^{-1}\right)$} & & & \\
\cline { 3 - 7 } & & 0 & $\mathrm{I}$ & $\mathrm{II}$ & III & IV \\
\hline $\mathbf{2 . 8}$ & 0.82 & 0.00 & 0.00 & 0.00 & 0.00 & 0.00 \\
$\mathbf{5 . 8}$ & 0.88 & 0.00 & 0.00 & 0.00 & 0.00 & 0.00 \\
$\mathbf{7 . 9}$ & 0.62 & 0.00 & 0.00 & 0.00 & 0.00 & 0.00 \\
$\mathbf{9 . 8}$ & 0.54 & 0.00 & 0.00 & 0.00 & 0.00 & 0.00 \\
$\mathbf{1 0 . 8}$ & 0.28 & 0.00 & 0.00 & 0.00 & 0.00 & 0.00 \\
$\mathbf{1 2 . 8}$ & 0.58 & 0.00 & 0.00 & 0.00 & 0.00 & 0.00 \\
$\mathbf{1 6 . 7}$ & 1.12 & 0.00 & 0.00 & 0.00 & 0.00 & $\mathbf{0 . 1 0}$ \\
$\mathbf{1 9 . 7}$ & 0.84 & 0.00 & $\mathbf{0 . 0 3}$ & $\mathbf{0 . 0 4}$ & $\mathbf{0 . 0 3}$ & 0.32 \\
$\mathbf{2 3 . 8}$ & 1.16 & 0.00 & 0.21 & 0.34 & 0.39 & 1.17 \\
$\mathbf{2 6 . 8}$ & 0.82 & $\mathbf{0 . 0 5}$ & 0.89 & 1.22 & 1.38 & 2.03 \\
$\mathbf{2 7 . 9}$ & 0.31 & 0.48 & 3.27 & 3.96 & 3.84 & 4.43 \\
$\mathbf{2 8 . 7}$ & 0.22 & 0.89 & 4.08 & 4.26 & 3.96 & 4.62 \\
\hline
\end{tabular}

sand in the $H_{\text {sand } 1}$ layer, the behavior of $\mathrm{Fe}^{0}$ in mediating contaminant removal can be characterized.

Fig. 4 summarized the time-dependant changes in the kinetics of MB discoloration for the whole experiments (89 days). In the reference system, MB discoloration occurred at a constant kinetics of about $58 \mathrm{mg} \mathrm{h}^{-1}$ from the start of the experiment to days 27 . Afterwards the discoloration rate decreased rapidly and reached $0 \mathrm{mg} \mathrm{h}^{-1}$ after 40 days. The trend for all $\mathrm{Fe}^{0}$-based systems was similar for the first 30 days. Instead of reaching the value $0 \mathrm{mg} \mathrm{h}^{-1}$, the MB discoloration rate went through a minimum $\left(8 \mathrm{mg} \mathrm{h}^{-1}\right)$ at day 30 and then progressively increased to reach a value of about $18 \mathrm{mg} \mathrm{h}^{-1}$ around day 45 . This value was kept constant through the end of the experiment (day 89). The $18 \mathrm{mg} \mathrm{h}^{-1} \mathrm{MB}$ discoloration corresponds to a constant kinetic of iron corrosion, $v_{0}$ (Eq. (1)). This is the short-term average rate of $\mathrm{Fe}^{0}$ corrosion. Because MB discoloration is not mediated by a chemical reaction with $\mathrm{Fe}^{0}$, this removal kinetics cannot be easily correlated to the kinetics of iron corrosion $\left(v_{0}\right)$. On the other hand, the minimum at day 30 hat no physical meaning.

The minimum of discoloration rate $\left(8 \mathrm{mg} \mathrm{h}^{-1}\right)$ at day 30 arises from the fact that before the breakthrough in the reference system, the absolute value of the MB concentration was used. At this stage MB adsorption onto (i) feeding bottles, (ii) connection tubes, (iii) collection bottles (Fig. 3) and (iv) sample vials were neglected. After MB breakthrough in the reference system, the effluent MB concentration of this system was set to $5.0 \mathrm{mg} \mathrm{L}^{-1}$ (no discoloration) and the $\mathrm{MB}$ concentration of all other systems were deduced using the rule of proportion. Here, adsorption onto PE and PET materials is still not properly considered, it is simply operationally ignored. It should be recalled that samples were properly handled to minimized adsorptive loss and avoid photocatalytic reactions.

\subsection{MB discoloration}

Fig. $5 \mathrm{a}$ and $\mathrm{b}$ shows that all $\mathrm{Fe}^{0}$-based systems behaved very closely with respect to $\mathrm{MB}$ discoloration (see also values in Tables 1 and 3). The results are summarized as follows: (i) MB discoloration in the reference system was quantitative for the first 30 days; (ii) the intermittence of column feeding does not bring any significant difference in MB discoloration, (iii) initial quantitative discoloration of $\mathrm{MB}$ in $\mathrm{Fe}^{0}$-based systems corresponds to adsorption onto $H_{\mathrm{sand}, 1}$ and (iv) for the whole experiment, the reference system was the most efficient at discoloring MB (Fig. 5b). Fig. 5a shows that he extent of breakthrough in $\mathrm{Fe}^{0}$-based systems was leveled to about $70 \%$ after some $30-45$ days and remained constant toward the end of the experiment. As discussed in Section 4.2, this is an evidence for the existence of a short-term average rate of $\mathrm{Fe}^{0}$ corrosion.

Fig. 5a and b cannot enable a graphical differentiation of the impact of $\mathrm{Cl}^{-}$on the extent of $\mathrm{Fe}^{0}$ corrosion: Assumption 2 is not validated in column studies. Even the $\mathrm{MB}_{\mathrm{ZV}}$ values in Table 1 and the $\Sigma \mathrm{MB}(\mathrm{mg}) / \mathrm{MB}(\%)$ values in Table 3. suggest just a slight increase of MB discoloration as the $\mathrm{Cl}^{-}$concentration varied from 0.0 to $1500 \mathrm{mg} \mathrm{L}^{-1}$ : Assumption 3 is somewhat validated. However, as discussed in Section 4.2, MB discoloration is mostly mediated by excess iron corrosion products, favoring co-precipitation or size-exclusion. The trend that MB discoloration increases with increasing $\mathrm{Cl}^{-}$level (Assumption 3) should be regarded as satisfactorily. Remember that early $\mathrm{MB}$ breakthrough was observed only in the system fed with the highest $\mathrm{Cl}^{-}$concentration (1500 $\mathrm{mg} \mathrm{L}^{-1}$ ), validating Assumption 1.

\section{4. $\mathrm{pH}$ values}

Fig. 6 summarizes the results of the evolution of the $\mathrm{pH}$ value (Fig. 6a) and the difference $\left(\mathrm{pH}_{\text {reference }}-\mathrm{pH}_{\text {system }}\right)$ (Fig. $6 \mathrm{~b}$ ) in the 


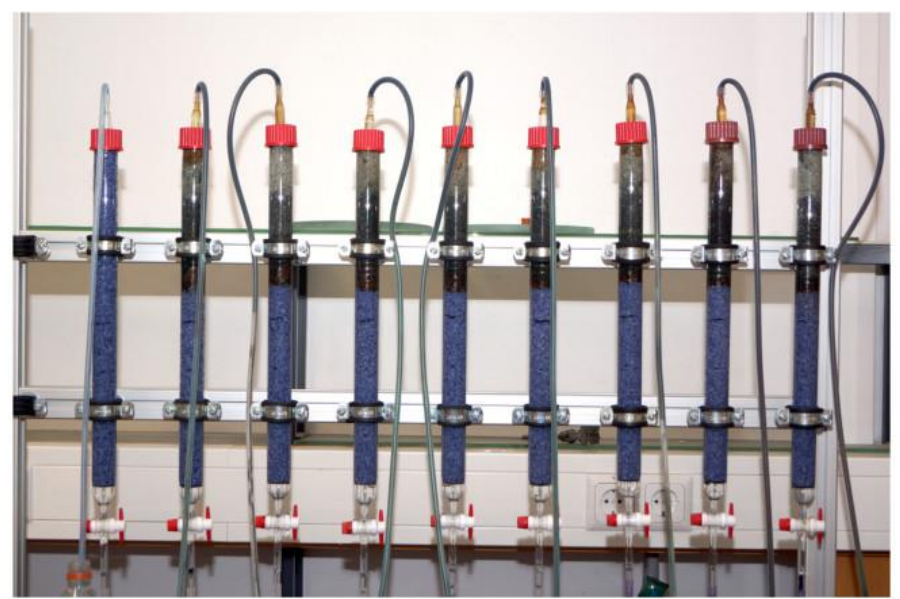

Fig. 3. Photograph of the column at the end of the experiments (after desorption). It is evident that: (i) MB adsorption onto sand is quantitative (first column left and all

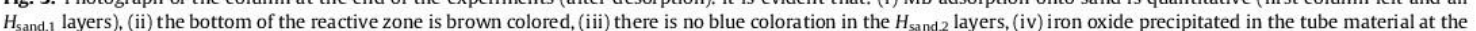
outlet, and (v) MB adsorbed onto the tube material. (For interpretation of the references to color in this figure legend, the reader is referred to the web version of this article.)

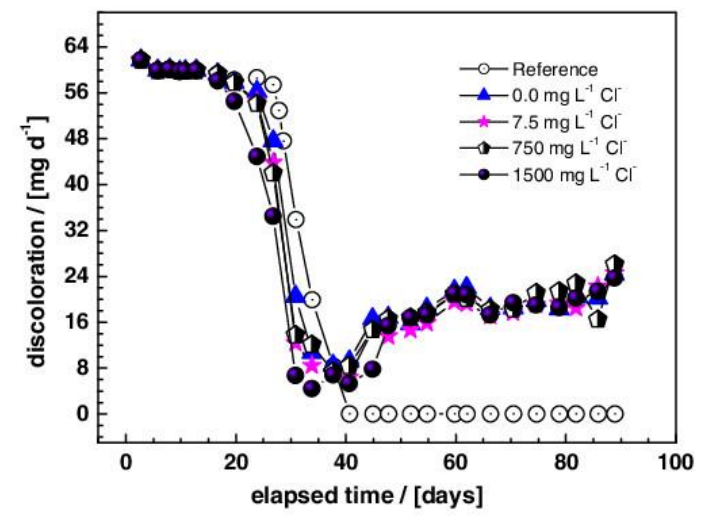

Fig. 4. Time-dependant extent of the kinetics $\left(\mathrm{mg} \mathrm{h}^{-1}\right)$ of methylene blue (MB) discoloration in the 9 investigated systems. Experimental conditions: $100 \mathrm{~g} \mathrm{Fe}^{0}$; $[\mathrm{MB}]=5.0 \mathrm{mg} \mathrm{L}^{-1}$; column length $42 \mathrm{~cm}$; column diameter $2.6 \mathrm{~cm}$. The lines are not fitting functions; they simply connect points to facilitate visualization.

effluent. It is seen that there is no significant change in the value of $\mathrm{pH}$ value in all the systems, including the reference system $(0 \%$ $\left.\mathrm{Fe}^{0}\right)$. This result is rationalized by the relative low mass of $\mathrm{Fe}^{0}$ used $(100 \mathrm{~g})$ and the low solubility of Fe for the concerned $\mathrm{pH}$ range (7.7-8.3). The absolute values related that the reference systems $\left(0 \% \mathrm{Fe}^{0}\right)$ exhibited a $\mathrm{pH}$ value of 8.3 and the $\mathrm{Fe}^{0}$-based systems lower $\mathrm{pH}$ values (7.7-8.1). However, these minor variations in $\mathrm{pH}$ value have no practical significance on the iron geochemistry of the system ([18] and ref. cited therein). The slight $\mathrm{pH}$ decreased is attributed to the buffer characteristics of iron hydroxides.

\subsection{Iron release}

Fig. 7 summarizes the results of iron release from the investigated systems. The results could be summarized as follows (Fig. 7a): (i) no iron was released from the reference system $(0 \%$ $\left.\mathrm{Fe}^{0}\right)$, (ii) moderate iron concentrations $\left(<1.0 \mathrm{mg} \mathrm{L}^{-1}\right)$ were leached
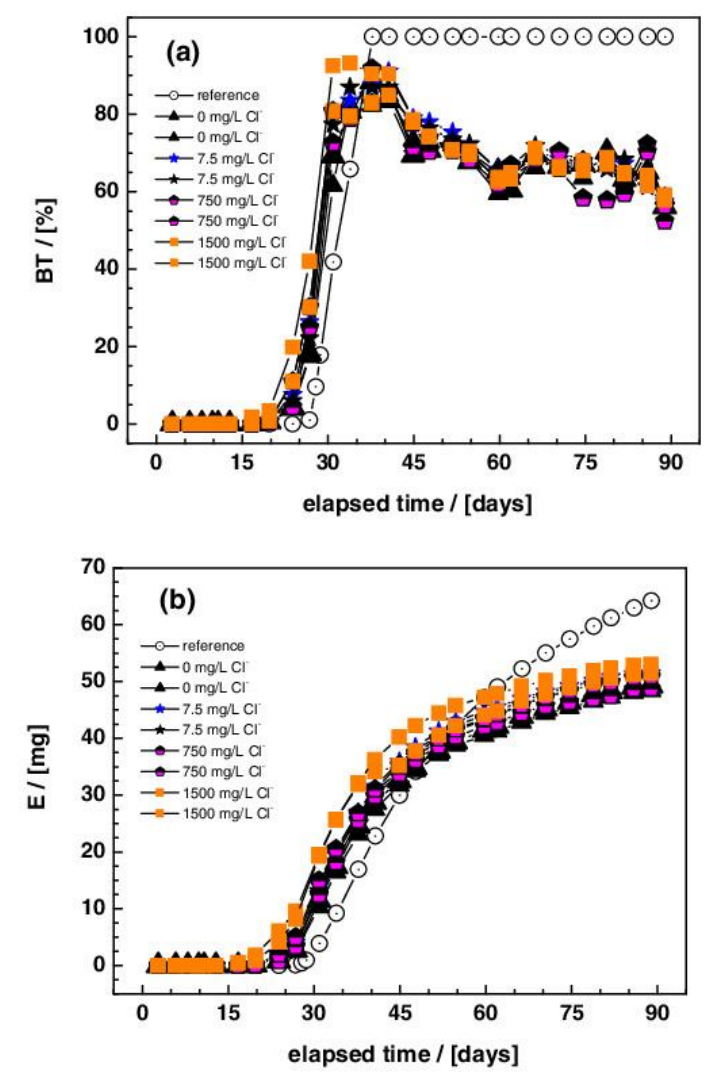

Fig. 5. Time-dependant extent of methylene blue (MB) discoloration in the 9 investigated systems: (a) MB breakthrough (\%) and (b) cumulative MB removal $(\mathrm{mg})$. Experimental conditions: $100 \mathrm{~g} \mathrm{Fe}^{0} ;[\mathrm{MB}]=5.0 \mathrm{mg} \mathrm{L}^{-1}$; column length $42 \mathrm{~cm}$; column diameter $2.6 \mathrm{~cm}$. The lines are not fitting functions; they simply connect points to facilitate visualization. 
Table 3

Summary of the results of column experiments; $\Sigma \mathrm{Fe}$ is the total mass of iron leached from the column and kept dissolved under the operational conditions; $\Sigma \mathrm{MB}$ is the total mass of MB discolored in the column. MB (\%) is the percent discoloration relative to the total MB mass that has flowed through the columns until the end of the discoloration experiment. $\mathrm{MB}_{\text {Desort }}(\mathrm{mg})$ is the total mass of $\mathrm{MB}$ leached from the column, $\mathrm{MB}_{\text {Desorpt }}(\%)$ the corresponding percentage relative to $\Sigma \mathrm{MB}$ and $[\mathrm{MB}]_{\text {final }}$ the $\mathrm{MB}$ concentration at the end of the desorption experiment. $d_{\text {compaction }}$ is the depth of compaction of the inlet site of the reactive zone at the end of the experiment.

\begin{tabular}{|c|c|c|c|c|c|c|c|c|c|c|}
\hline \multirow[t]{2}{*}{ Parameter } & \multirow[t]{2}{*}{ Unit } & \multicolumn{9}{|c|}{ Column } \\
\hline & & 1 & 2 & 3 & 4 & 5 & 6 & 7 & 8 & 9 \\
\hline$\Sigma \mathrm{Fe}$ & $(\mathrm{mg})$ & 0.0 & 6.0 & 8.6 & 15.5 & 14.7 & 8.7 & 8.3 & 11.6 & 20.8 \\
\hline$\Sigma \mathrm{MB}$ & (mg) & 79.8 & 60.1 & 61.2 & 64.0 & 62.9 & 60.6 & 63.3 & 60.8 & 65.8 \\
\hline MB & (\%) & 64.2 & 48.4 & 49.2 & 51.5 & 50.7 & 48.8 & 51.0 & 51.5 & 53.0 \\
\hline $\mathrm{MB}_{\text {Desorpt }}$ & (mg) & 8.9 & 9.6 & 9.6 & 9.7 & 11.0 & 9.7 & 10.1 & 9.1 & 9.5 \\
\hline $\mathrm{MB}_{\text {Desorpt }}$ & (\%) & 11.1 & 16.0 & 15.8 & 15.2 & 17.5 & 16.0 & 16.0 & 15.0 & 14.5 \\
\hline$[\mathrm{MB}]_{\text {final }}$ & $(\mathrm{mg} / \mathrm{L})$ & 0.44 & 1.13 & 1.09 & 1.09 & 1.12 & 1.17 & 1.19 & 1.20 & 1.13 \\
\hline$d_{\text {Compaction }}$ & $(\mathrm{cm})$ & 0.0 & 2.0 & 2.0 & 1.5 & 1.5 & 1.0 & 1.0 & 1.0 & 1.0 \\
\hline
\end{tabular}
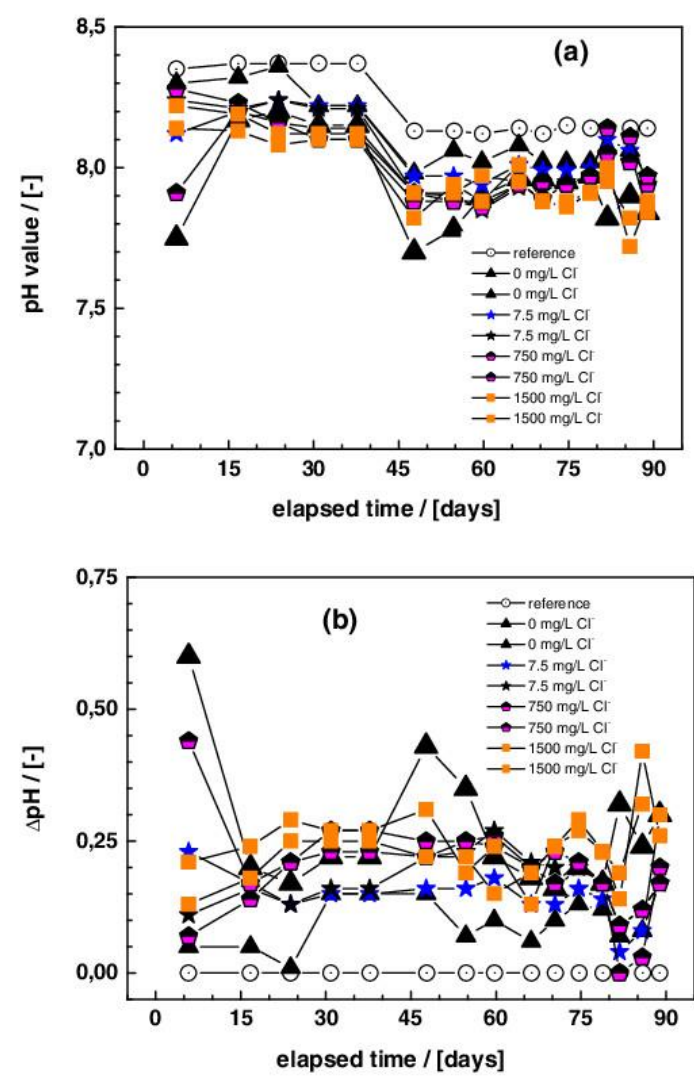

Fig. 6. Time-dependant extent of changes in $\mathrm{pH}$ value for the 9 investigated systems: (a) absolute value and (b) variation relative to the reference system. Experimental conditions: $100 \mathrm{~g} \mathrm{Fe}^{0} ;[\mathrm{MB}]=5.0 \mathrm{mg} \mathrm{L}^{-1}$; column length $42 \mathrm{~cm}$; column diameter $2.6 \mathrm{~cm}$. The lines are not fitting functions; they simply connect points to facilitate visualization.

from the system with $0.0 \mathrm{mg} \mathrm{L}^{-1} \mathrm{Cl}^{-}$, (iii) higher iron concentrations $\left(>1.0 \mathrm{mg} \mathrm{L}^{-1}\right)$ were leached from systems with added $\mathrm{Cl}^{-}$. A careful look of Fig. 7a suggests that the iron concentration of the column fed with $1500 \mathrm{mg} \mathrm{L}^{-1} \mathrm{Cl}^{-}$was significantly higher. This observation is clearer in Fig. 7b where the cumulative mass of leached $\mathrm{Fe}$ is represented as a function of the experimental duration. The $\Sigma$ Fe data from Table 3 confirm that system fed with $\mathrm{Cl}^{-}$quantitatively exhibited higher Fe release (Assumption 2 is validated).
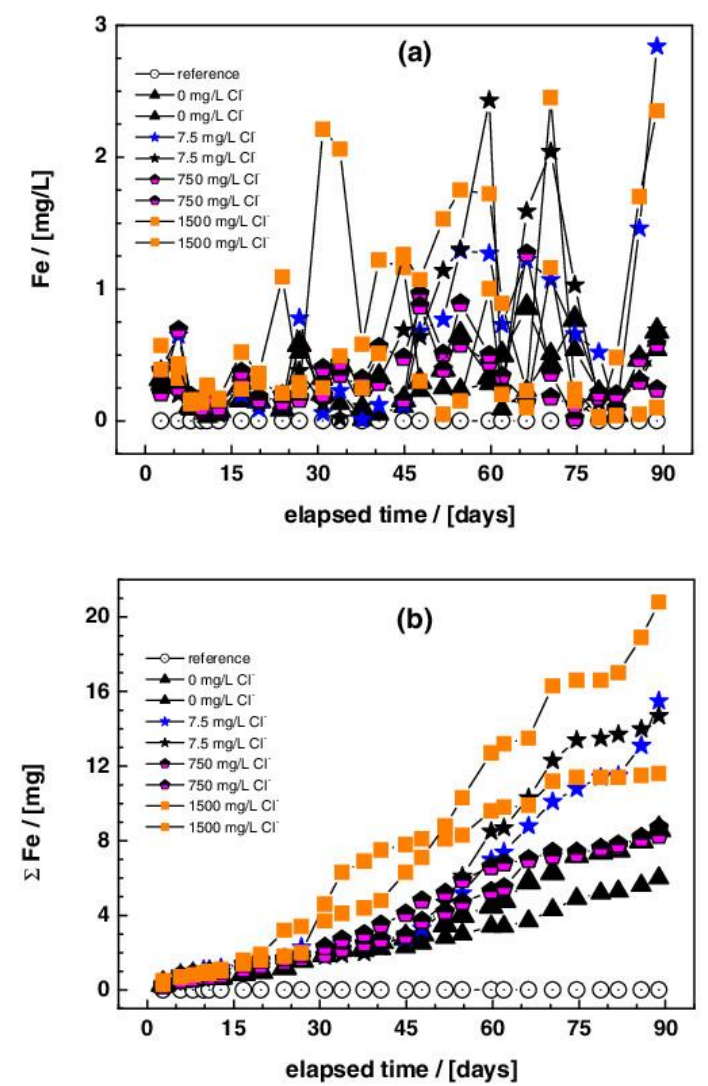

Fig. 7. Time-dependant extent of changes in effluent iron concentration for the 9 investigated systems: (a) absolute value ( $\mathrm{mg} \mathrm{L}^{-1}$ ) and (b) cumulative iron release (mg). Experimental conditions: $100 \mathrm{~g} \mathrm{Fe}^{0} ;[\mathrm{MB}]=5.0 \mathrm{mg} \mathrm{L}^{-1}$; column length $42 \mathrm{~cm}$; column diameter $2.6 \mathrm{~cm}$. The lines are not fitting functions; they simply connect points to facilitate visualization.

The mean values for the duplicates varies from $7.3 \mathrm{mg}$ for the $\mathrm{Cl}^{-}: 0.0 \mathrm{mg} \mathrm{L}^{-1}$ system to $16.2 \mathrm{mg}$ for the $\mathrm{Cl}^{-}: 1500 \mathrm{mg} \mathrm{L}^{-1}$ system. There was no (monotone) linear trend as the value for the $\mathrm{Cl}^{-}$: $7.5 \mathrm{mg} \mathrm{L}^{-1}$ system (15.1) was larger than that for the $\mathrm{Cl}^{-}$. $750 \mathrm{mg} \mathrm{L}^{-1}$ system (11.6). However, Fe release results from several interdependent complex processes [18]. Summarized, iron dissolved from $\mathrm{Fe}^{0}$ can only migrate in short distances at the $\mathrm{pH}$ range of the experiments. Due to the low solubility at $\mathrm{pH}>5.0$, dissolved 
Fe is adsorbed and precipitated on sand particle (in situ coating) and tubing materials as visually observed (Figs. 1 b and 3). These reaction products lower adsorption of $\mathrm{Fe}^{\mathrm{III}}$ and $\mathrm{Fe}^{\mathrm{III}}$ species onto sand and accelerated iron breakthrough.

Despite the complexity of processes yielding Fe release from the column, the time dependant changes of the iron concentration presented the most direct proof that $\mathrm{Cl}^{-}$ions accelerated iron corrosion, validating Assumption 2 also in column study. This explains early $\mathrm{MB}$ breakthrough from the systems with the largest $\mathrm{Cl}^{-}$concentration (Assumption 1) but also the low level of difference between the investigated systems. Remember that MB early breakthrough reveals a higher efficiency of the $\mathrm{Fe}^{0} / \mathrm{H}_{2} \mathrm{O}$ system for species readily removed by iron corrosion products (e.g. $\mathrm{As}^{\mathrm{V}}$ and $\mathrm{Cr}^{\mathrm{VI}}$ ).

\subsection{Hydraulic conductivity (permeability)}

The present work used the same experimental design as Miyajima and Noubactep [27] and Phukan et al. [18] but a shorter experimental duration. Thus, the used pump flow rate $\left(0.1 \mathrm{~mL} \mathrm{~min}^{-1}\right)$ was thus sufficient to transport enough in situ generated iron oxides out of the reactive zone to avoid significant loss of permeability due to cementation. The hydraulic conductivity had a constant value of about $11.5 \mathrm{~mL} \mathrm{~h}^{-1}$ for all systems during the whole experiment (results not shown). Intermittent filtration has not impacted the system permeability as well.

\subsection{Desorption experiments}

Fig. 8 and Table 3 summarize the results of MB desorption by $6.71 \mathrm{~L}\left(t_{f}=24.5\right.$ days $)$ of tap water following the discoloration experiment. Table 3 shows that the extent of MB desorption varied from $11.1 \%$ to $17.5 \%$ relative to the discoloration level in each system. Fig. 8 clearly shows a differential kinetics of the desorption process. MB desorption from sand (reference) was rapid and quantitative: from $5 \mathrm{mg} \mathrm{L}^{-1}$ at $t_{0}=0$ days to $0.44 \mathrm{mg} \mathrm{L}^{-1}$ at $t_{f}=24.5$ days (decreasing factor: 11.4). On the contrary, MB desorption from $\mathrm{Fe}^{0}$-based systems was initially relative low and only slowly decreased with the experimental duration. MB concentration decreased from $3.0 \mathrm{mg} \mathrm{L}^{-1}$ at $t_{0}=0$ days to about $1.15 \mathrm{mg} \mathrm{L}^{-1}$ at $t_{f}=24.5$ days (decreasing factor: 2.6 ). These results are rationalized by the differential discoloration mechanisms: (i) pure adsorption onto sand and (ii) adsorption (see Section 2), co-precipitation and

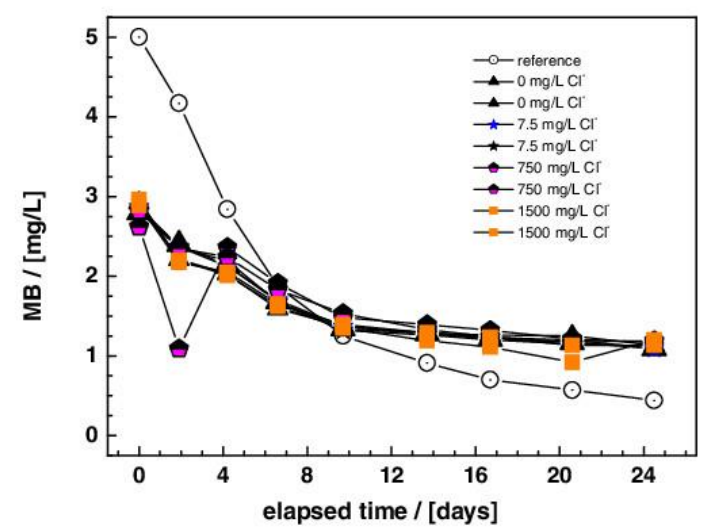

Fig. 8. Time-dependant extent of methylene blue (MB) release (desorption) from the 9 investigated systems. The leaching solution was the tap water of Göttingen used as solvent for the preparation of $\mathrm{MB}$ solutions. The lines are not fitting functions; they simply connect points to facilitate visualization. size-exclusion in the $\mathrm{Fe}^{0}$ /sand system. Essentially, co-precipitated MB cannot be leached by water, because water cannot dissolve iron oxides. Accordingly, leached MB mostly corresponds to the fraction weakly adsorbed onto iron-oxide coated sand.

The slowness of MB discoloration from iron oxides was recently documented by Phukan et al. [18] and corresponds to the observed slowness of contaminant desorption from geomaterials. This slow desorption kinetics is the main reason of the failure of the pump-and-treat technology for groundwater remediation [28].

\subsection{Compaction of column material}

A brown coloration was observed in the entrance zone of all $\mathrm{Fe}^{0}$-based columns. This coloration is characteristic for $\mathrm{Fe}^{\mathrm{III}}$ oxides commonly termed as rust. Usually solid materials ( $\mathrm{Fe}^{0}$ and sand) are cemented to a compact mass. This cementation corresponds to the progressive loss of interconnectivity of the initial inter-particular porosity $[17,18,29]$.

The observed brown coloration corresponds to $1.0-2.0 \mathrm{~cm}$ compacted solid in the lower part (entrance zone) of $\mathrm{Fe}^{0}$ (Table 3). As a matter of fact, no compaction was observed in the reference system, the $H_{\text {sand1 }}$ and the $H_{\text {sand2 }}$ layers. Table 3 reveals that the compaction depth was minimal $(1.0 \mathrm{~cm})$ for the systems fed with the both highest chlorine concentrations ( 750 and $1500 \mathrm{mg} \mathrm{L}^{-1}$ ). The materials in these systems were also harder compacted (more difficult to remove from the columns). Remember that iron release was higher for these both systems. The rest of the reactive zone was black in color and appeared visually similar to the original $\mathrm{Fe}^{0}$ material. This corresponds to the observation made in previous works $[18,29]$ and suggests that systems using more reactive $\mathrm{Fe}^{0}$ materials may be prone to rapid permeability loss. Investigating the systems herein for longer experimental duration would bring more light into this issue.

\subsection{Summary and applications}

The idea to test organic dyes for the characterization of the $\mathrm{Fe}^{0} /$ system was introduced some three years ago [27]. Previous works have tested $\mathrm{Fe}^{0}$ as removing agent for dyes mostly in wastewater treatment ([27] and ref. cited therein). In successfully testing dyes in general and MB in particular as operative indicators for the characterization of $\mathrm{Fe}^{0} /$ systems, the practicability and cost-efficiency of experimental devices using dyes [18,22] is made available for the investigation of various aspects relevant for the design of $\mathrm{Fe}^{0}$ filters. This aspect is important for scientific research under financially less favorable conditions (e.g. developing countries).

The results reported herein have validated the suitability of MB to characterize the effects of chloride ions on the efficiency of $\mathrm{Fe}^{0} / \mathrm{H}_{2} \mathrm{O}$ systems for contaminant removal. Little differentiation of the extent of chloride concentration varying from 0.0 to $1500 \mathrm{mg} \mathrm{L}^{-1}$ was possible in column experiments based on the extent of MB discoloration (Assumption 2). However, the extent of Fe release and the extend of material compaction enabled a clear conclusion. Results from batch experiments also validate Assumption 2. The seemingly less reliability of the results of MB discoloration in column experiments is attributed to the fact that, under operational conditions, MB discoloration is mediated by precipitating excess 'free' corrosion products (MB co-precipitation) (Assumption 3). This excess has not quantitatively accumulated in the system but was transported out of the column as observed on the coloration of tubing materials. In other words, a better differentiation on the basis of MB discoloration would have been obtained with a shorter $H_{\text {sand1 }}$ layer $(<24 \mathrm{~cm})$, a higher initial MB concentration or a less reactive $\mathrm{Fe}^{0}$ material. In turn, a shorter $H_{\text {sand } 1}$ layer implies difficulties in removing materials from the 
glass columns at the end of the experiment [18,24]. The early MB breakthrough in the system with the largest chlorine concentration (Table 2) evidences the suitability of MB discoloration to characterize the impact of $\mathrm{Cl}^{-}$on the efficiency of $\mathrm{Fe}^{0} / \mathrm{H}_{2} \mathrm{O}$ systems (Assumption 1).

The primary mechanism of contaminant removal by filtration is pure mechanical size exclusion (straining - size exclusion). The cross-sectional area of MB is $120 \AA^{2}$ and its molecular size 13$15 \AA$. In other words, the volume occupied by individual MB molecules is in the order of $1800 \AA^{3}$. An evaluation of the pore size (inter-granular distance) under tested experimental conditions is difficult to achieve. However, it is certain that the inter-granular distance between $\mathrm{Fe}^{\mathrm{O}}$ and sand grains is in the order of $\mathrm{mm}$ $\left(10^{7} \AA\right)$. Clark et al. [30] reported that the distance between grains of very fine sand ( 60 micrometers mean diameter) is in the order of $\mu \mathrm{m}$. Similarly the pore size for the investigations herein is in the order of mm (Section 2.1). Accordingly, MB can only be adsorbed onto sand (adsorptive filtration) or rejected by iron oxides and iron oxide coated sand (charge exclusion). Two other discoloration mechanisms, mostly relevant in the long term are: (i) MB co-precipitation by precipitating corrosion products and (ii) MB straining by virtue of pore size reduction through accumulation of corrosion products (Assumption 3, also validated herein). The results presented herein (Table 2 ) have clearly documented early MB breakthrough due to in situ coating of the sand layer after the reactive zone, validating Assumption 1. The less clear trend for other relevant processes (Assumption 2 and Assumption 3) is due to their stochastic nature [27] and corroborate the view that the abundance of controversial reports in the $\mathrm{Fe}^{0}$ literature is mostly due to differences in experimental designs $[2,17,18]$ and their appropriateness to resolve the research objectives. In fact, nobody would come to the idea that $\mathrm{Cl}^{-}\left(13-1500 \mathrm{mg} \mathrm{L}^{-1}\right)$ has no impact on the kinetics of iron corrosion, just because the expected trend is not observed at first glance. The real conclusion is thus, that the experimental conditions were not optimal for the expected observations. Tools for better observations are discussed. The experimental design used herein could be slightly modified and used to elucidate the role of environmental anions $\left(\mathrm{Cl}^{-}, \mathrm{HCO}_{3}^{-}, \mathrm{NO}_{3}^{-}, \mathrm{PO}_{4}^{3-}, \mathrm{SO}_{4}^{2-}\right)$ on the process of iron corrosion. This effort could start with parallel column studies using the $\mathrm{Fe}^{\mathrm{O}}$ material tested herein and the following parameters: $[\mathrm{MB}]=5 \mathrm{mg} \mathrm{L}^{-1}, H_{\mathrm{sand} 1}=12 \mathrm{~cm}$, [anions] $=21.1 \mathrm{mM}$ (corresponding to $750 \mathrm{mg} \mathrm{L}^{-1} \mathrm{Cl}^{-}$), flow velocity: $11.5 \mathrm{~mL} \mathrm{~h}^{-1}$.

\section{Concluding remarks}

The present work shows that MB is a powerful operative indicator for the characterization of the reactivity of $\mathrm{Fe}^{0} / \mathrm{H}_{2} \mathrm{O}$ systems. The univocally reported enhanced aqueous iron corrosion in the presence of chloride ions is confirmed. The ion-selective nature of $\mathrm{Fe}^{0} / \mathrm{H}_{2} \mathrm{O}$ systems is also confirmed: cationic $\mathrm{MB}$ is weakly adsorbed onto positively charged iron oxides (partly in situ coated on sand). This work provides useful guidance for subsequent laboratory investigations focused on the elucidation of the effects of water chemistry on the efficiency of $\mathrm{Fe}^{0} / \mathrm{H}_{2} \mathrm{O}$ systems for environmental remediation and water treatment. Relevant parameters to be investigated include the initial concentration of (i) carbonate ions, (ii) humic substances, (iii) nitrate ions, (iv) phosphate ions and (v) sulfate ions. More research is needed with MB and at least one anionic dye (e.g. Orange II or methyl orange).

\section{Acknowledgements}

Lothar Laake and Gerhard Max Hundertmark from the Geosciences Center (University of Göttingen) are acknowledged for technical support. The manuscript was improved by the insightful comments of anonymous reviewers from Chemical Engineering Journal.

\section{References}

[1] A.D. Henderson, A.H. Demond, Long-term performance of zero-valent iron permeable reactive barriers: a critical review, Environ. Eng. Sci. 24 (2007) $401-$ 423.

[2] X. Guan, Y. Sun, H. Qin, J. Li, L.M.C. Lo, D. He, H. Dong, The limitations of applying zero-valent iron technology in contaminants sequestration and the corresponding countermeasures: the development in zero-valent iron technology in the last two decades (1994-2014), Water Res. 75 (2015) 224248.

[3] G. Bartzas, K. Komnitsas, Solid phase studies and geochemical modelling of low-cost permeable reactive barriers, J. Hazard. Mater. 183 (2010) 301-308.

[4] L. Li, C.H. Benson, Evaluation of five strategies to limit the impact of fouling in permeable reactive barriers, J. Hazard. Mater. 181 (2010) 170-180.

[5] M. Gheju, Hexavalent chromium reduction with zero-valent iron (ZVI) in aquatic systems, Water Air Soil Pollut, 222 (2011) 103-148.

[6] R.T. Wilkin, S.D. Acree, R.R. Ross, R.W. Puls, T.R. Lee, L.L. Woods, Fifteen-year assessment of a permeable reactive barrier for treatment of chromate and trichloroethylene in groundwater, Sci. Total Environ. 468-469 (2014) 186 194.

[7] A. Hussam, A.K.M. Munir, A simple and effective arsenic filter based on composite iron matrix: development and deployment studies for groundwater of Bangladesh, J. Environ. Sci. Health A 42 (2007) 1869-1878.

[8] K.P. Kowalski, E.G. Søgaard, Implementation of zero-valent iron (ZVI) into drinking water supply - role of the ZVI and biological processes, Chemosphere 117 (2014) $108-114$

[9] S. Nesic, Key issues related to modelling of internal corrosion of oil and gas pipelines - a review, Corros. Sci. 49 (2007) 4308-4338.

10] J.L. Alamilla, M.A. Espinosa-Medina, E. Sosa, Modelling steel corrosion damage in soil environment, Corros. Sci. 51 (2009) 2628-2638.

[11] C. Noubactep, Designing metallic iron packed-beds for water treatment: a critical review, Clean - Soil, Air Water (2015), http://dx.doi.org/

[12] R. Firdous, J.F. Devlin, Consideration of grain packing in granular iron treatability studies, J. Contam. Hydrol. 164 (2014) 230-239.

[13] C. Noubactep, Flaws in the design of $\mathrm{Fe}(0)$-based filtration systems? Chemosphere 117 (2014) 104-107

[14] R. Tepong-Tsindé, R. Crane, C. Noubactep, A. Nassi, H. Ruppert, Testing metallic iron filtration systems for decentralized water treatment at pilot scale, Water 7 (2015) 868-897.

[15] W. Chen, R. Parette, F.S. Cannon, Pilot-scale studies of arsenic removal with granular activated carbon and zero-valent iron, Environ. Eng. Sci. 29 (2012)

[16] J.C. Crittenden, P.S. Reddy, H. Arora, J. Trynoski, D.W. Hand, D.L. Perram, R.S. Summers, Predicting GAC performance with rapid small-scale col umn tests, J. Am. Water Works Assoc, 83 (1991) 77-87.

[17] B.D. Btatkeu-K., H. Olvera-Vargas, J.B. Tchatchueng, C. Noubactep, S. Caré, Characterizing the impact of $\mathrm{MnO}_{2}$ on the efficiency of $\mathrm{Fe}^{0}$-based filtration systems, Chem. Eng. J. 250 (2014) 416-422.

[18] M. Phukan, C. Noubactep, T. Licha, Characterizing the ion-selective nature of $\mathrm{Fe}^{0}$-based filters using azo dyes, Chem. Eng. J. 259 (2015) 481-491.

[19] G. Kim, W. Jeong, S. Choe, Dechlorination of atrazine using zero-valent iron $\left(\mathrm{Fe}^{0}\right)$ under neutral pH conditions, Environ. Pollut. 147 (2007) 634-641.

[20] G. Mitchell, P. Poole, H.D. Segrove, Adsorption of methylene blue by high-silica sands, Nature 176 (1955) 1025-1026.

[21] S. Noonpui, P. Thiravetyan, Treatment of reactive azo dye from textile wastewater by burhead (Echinodorus cordifolius L.) in constructed wetland: effect of molecular size, J. Environ. Sci. Health A 46 (2011) 709-714.

[22] C. Noubactep, Characterizing the discoloration of methylene blue in $\mathrm{Fe}^{0} / \mathrm{H}_{2} \mathrm{O}$ systems, J. Hazard. Mater. 166 (2009) 79-87.

[23] C. Trois, A. Cibati, South African sands as a low cost alternative solution for arsenic removal from industrial effluents in permeable reactive barriers: column tests, Chem. Eng. J. 259 (2015) 981-989.

[24] P. Westerhoff, J. James, Nitrate removal in zero-valent iron packed columns, Water Res. 37 (2003) 1818-1830.

[25] W.B. Fortune, M.G. Mellon, Determination of iron with o-phenanthroline: spectrophotometric study, Ind. Eng. Chem. Anal. Ed. 10 (1938) 60-64.

[26] S.B. Bukallah, M.A. Rauf, S.S. AlAli, Removal of methylene blue from aqueous solution by adsorption on sand, Dyes Pigm, 74 (2007) 85-87.

[27] K. Miyajima, C. Noubactep, Impact of $\mathrm{Fe}^{0}$ amendment on methylene blue discoloration by sand columns, Chem, Eng. J. 217 (2013) 310-319.

[28] M.D. Mackay, J.A. Cherry, Groundwater contamination: pump-and-treat remediation, Environ. Sci. Technol. 23 (1989) 630-636.

[29] P.D. Mackenzie, D.P. Horney, T.M. Sivavec, Mineral precipitation and porosity losses in granular iron columns, J. Hazard, Mater. 68 (1999) 1-17.

[30] P.A. Clark, C.A. Pinedo, M. Fadus, S. Capuzzi, Slow-sand water filter: Design, implementation, accessibility and sustainability in developing countries, Med. Sci. Monit. 18 (2012) RA105-RA117. 
Water 2014, 6, 1-x manuscripts; doi:10.3390/w60x000x

Concept Paper

\title{
Testing metallic iron filtration systems for decentralized water treatment at pilot scale
}

Raoul Tepong-Tsindé ${ }^{1,2, \dagger}$, Richard Crane ${ }^{3, \dagger}$, Chicgoua Noubactep ${ }^{1,4,5, *}$ Achille Nassi ${ }^{2, \dagger}$ and Hans Ruppert ${ }^{6, \dagger}$

1 Department of Chemistry, Faculty of Sciences, University of Douala, B.P. 24157 Douala, Cameroon, raoultepong@googlemail.com; achillen@yahoo.fr;

2 Department of Applied Geology, University of Göttingen, Goldschmidtstraße 3, D - 37077 Göttingen, Germany, cnoubac@gwdg.de;

3 School of Civil and Environmental Engineering, University of South Wales, 110 King St, Manly Vale, NSW, 2093, Australia, r.crane@unsw.edu.au;

4 Kultur und Nachhaltige Entwicklung CDD e.V., Postfach 1502, D - 37005 Göttingen, Germany;

5 Comité Afro-européen - Avenue Léopold II, 41 - 5000 Namur, Belgium;

6 Department of Sedimentology \& Environmental Geology, University of Göttingen, Goldschmidtstraße 3, D - 37077 Göttingen, Germany; hrupper@gwdg.de.

$\dagger$ These authors contributed equally to this work.

* Author to whom correspondence should be addressed; E-Mail: cnoubac@gwdg.de; Tel.: +49 551393 3191; Fax: +49551399379.

External Editor:

Received: / Accepted: / Published:

\begin{abstract}
There are many factors to consider for the design of appropriate water treatment systems including: cost, the concentration and type of biological and/or chemical contamination, concentration limits at which contaminant(s) are required to be removed, required flow rate, level of local expertise for on-going maintenance, and social acceptance. An ideal technology should be effective at producing clean, potable water; however it must also be low-cost, low-energy (ideally energy-free) and require lowmaintenance. The use of packed beds containing metallic iron ( $\mathrm{Fe}^{0}$ filters) has the potential to become a cheap widespread technology for both safe drinking water provision and
\end{abstract}


wastewater treatment. $\mathrm{Fe}^{0}$ filters have been intensively investigated over the past two decades, however, sound design criteria are still lacking. This article presents an overview of the design of $\mathrm{Fe}^{0}$ filters for decentralized water treatment particularly in the developing world. A design for safe drinking water to a 100 people community is also discussed as starting module. It is suggested that $\mathrm{Fe}^{0}$ filters have the potential for significant worldwide applicability, but particularly in the developing world. The appropriate design of $\mathrm{Fe}^{0}$ filters, however, is site-specific and dependent upon the availability of local expertise/materials.

Keywords: Decentralized water treatment; Deep-bed filtration; Pilot study; Water supply; Zerovalent iron.

\section{Introduction}

\subsection{Background}

In recent years the use of decentralized water treatment systems has increased worldwide, but particularly in the developing world [1-10]. Due to their relatively small spatial scale and low carbon footprint, decentralized water filtration systems have a low environmental impact on water resources because they do not discharge effluent into waterways [4]. Furthermore, each decentralized water treatment system can be customized to suit local water quality objectives, climatic and topographic conditions and aesthetic requirements. Conventional water treatment is often a complex multistage processes (namely coagulation, disinfection, flocculation, sand filtration, screen-filtration, ozonisation, sedimentation) and requires a wide array of chemicals (namely chlorine, flocculent, hydrogen peroxide, lime, ozone). They therefore also typically require specialist expertise for installation and maintenance $[4,10,11-13]$. As a result conventional wastewater treatment facilities are often expensive to install and maintain and have a high carbon footprint. This has motivated the development of alternative "one-step" technologies which include membrane filters (e.g. reverse osmosis, ultrafiltration), functionalized adsorbents and ion exchange resins.

Membrane filtration technologies typically exhibit a number of advantageous attributes including $[3,7]$ : (i) the ability to produce very high quality water (low aqueous contaminant concentrations); (ii) simple modular design and the ability to be automated; (iii) no requirement for chemicals; and (iv) the 
ability to effectively remove bacteria, viruses and other microorganisms. Conventional membrane filtration can be divided into three stages: pre-filtration (media filtration), ultra-filtration and reverse osmosis. However, three key disadvantages associated with membrane filtration systems are the high installation cost, high energy requirement and the necessity for maintenance (removal of membrane fowling material). As a consequence, over the past few decades much research has been conducted into the development of more cost effective and simple water treatment systems for the developing world $[3,4,7,12-18]$. These efforts include the development of renewable energy powered membrane (REmembrane) technologies [19,20]. Resulting water treatment systems are flexibly scalable from devices using individual modules for household water supply (e.g. Lifestraws and Homespring) to large scale water supplies for mega-cities [20]. Process selection can be adjusted to any water quality and desired contaminant removal. The Portable Aqua Unit for Lifesaving (PAUL), also known as Water Backpack [13] will be presented as an example in the following section.

\subsection{Membrane technology can be a bridging solution}

PAUL is a portable membrane water filter (pore size: 20 to $100 \mathrm{~nm}$ ) developed at the University of Kassel (Germany) for humanitarian aid [13]. It is designed for the specific purpose of decentralized water treatment in emergency and disaster situations. PAUL functions without chemicals or energy input and during its "lifetime" there is no need for technical maintenance. A PAUL device can produce safe water for up to 700 persons for several months. Furthermore PAUL has been demonstrated as highly effective for the removal of $99.999 \%$ of bacteria (escherichia coli and coliform) and $99.9 \%$ of viruses (coliphages). The performance of PAUL and other similar gravity driven membrane filtration systems for the treatment of chemical contaminant species (e.g. hydrocarbons, metals, metalloids, radionuclides), however, has been demonstrated as less effective. PAUL and similar membrane filtration systems are therefore inappropriate for the procurement of potable water in remote communities where such aqueous contaminant species (including arsenic, fluoride and nitrate) are above minimal threshold levels. Accordingly, there remains a need for the development of alternative 
and/or complimentary technologies for water treatment. Gravity filtration using $\mathrm{Fe}^{0}$ has been discussed in the literature as a potential candidate technology due to the ability of $\mathrm{Fe}^{0}$ to both remove microorganisms, degrade organic contaminants and also immobilize metal and metalloid species $[14,15,18-27]$

\subsection{The suitability of $\mathrm{Fe}^{0}$ filters for safe water provision in the developing world}

The idea of using metal corrosion for the in-situ generation of metal hydroxides for aqueous contaminant removal is the basis of electro-coagulation, essentially using $\mathrm{Al}^{0}$ and $\mathrm{Fe}^{0}$ as electrodes. Noubactep and Schöner [28] have discussed the similarities between decontamination by electrocoagulation and by using granular metallic materials. According to Bojic et al. [29], the great efficacy of voluminous insoluble $\mathrm{Al}(\mathrm{OH})_{3}$ for aqueous removal of many chemical and microbiological pollutants implies efficient water decontamination by a microalloyed aluminium based composite. Bojic et al. [29] positively tested this idea to eliminate Escherichia coli from a model surface water and later for various chemical contaminants including $\mathrm{Cr}, \mathrm{Cu}$, halogenated trihalomethanes and $\mathrm{Zn}$ $[30-32]$.

In an independent approach, $\mathrm{Fe}^{0}$ was used as a reducing agent or generator of iron hydroxides for water treatment [33-35]. By 2002, $\mathrm{Fe}^{0}$ was already tested for many relevant groups of chemical contamination. With the publication of the work of You et al. [36] entitled "Removal and inactivation of waterborne viruses using zerovalent iron", $\mathrm{Fe}^{0}$ was demonstrated to be a universal material for water treatment. Since then, a great deal of work has established the potential of $\mathrm{Fe}^{0}$ for water desinfection [37-41].

The suitability of $\mathrm{Fe}^{0}$ filters for safe water provision in the developing world arises from their ability to treat chemical and biological contamination. Pathogens, arsenic and fluoride are arguably the three main pollutants of worldwide relevance [42-45]. The ability of $\mathrm{Fe}^{0}$ filters to remove salt ions (e.g. 
fluoride) and trace contaminants (e.g. arsenic) makes this technology more suitable than gravity-based membrane technology for deployment in remote areas.

\subsection{Fe filters for self-reliance in water supply}

This article presents a comprehensive overview of the science and rationale for the use of $\mathrm{Fe}^{0}$ for decentralized water treatment. In particular a working methodology is presented which is intended to function as a basis for future work, which comprises a hypothetic scenario wherein $\mathrm{Fe}^{0}$ is used for the provision of potable water to a community with 100 inhabitants $\left(1 \mathrm{~m}^{3}\right.$ water/day). This population size has been selected because it is considered to be one "production module" which can then be scaled upwards for communities of different population. For example, a community with 400 inhabitants would require 4 production modules. Downwards scaling for communities with less than 100 inhabitants is not discussed but the expertise from the present effort would also enable downscaling.

\section{Water supply systems}

\subsection{Centralized water supply}

Centralized water supply represents the conventional water supply approach $[4,6]$. This approach is based on providing water through water supply schemes including components such as: water source development (namely boreholes, rainwater or rivers), water distribution systems (namely piping systems), water storage systems (namely overhead tanks). A ready source of power supply is needed to run the schemes and a distribution network $[4,6,18,46,47]$. Individual homes are expected to be connected to the distribution network (Fig. 1). Centralized water supply systems are typically available in cities both in the developed and developing world, and small communities in the developed world. In urban areas of the developing world, water is often quantitatively available. However, ineffective water supply chains frequently result in low quality $[11,46]$.

\subsection{Disadvantages of the centralized water supply}


Centralized water supply systems may be prohibitively expensive to install, operate and maintain for low-income and/or remote communities. This is due to a number of reasons including: (i) intermittent power supply (e.g. lack of fuel); (ii) lack of infrastructure; and (iii) lack of technical knowledge to maintain infrastructure $[1,6,11,21]$. Accordingly, there is a urgent need to develop affordable yet also low maintenance technologies for the water supply of low-income and remote communities.

Figure 1. Concept of water treatment train based on filtration on granular materials and including at least one sand filter for media filtration (roughing filter). Further units may comprise: (i) biosand filter, (ii) activated carbon filter, $\mathrm{Fe}^{\%} /$ sand filter. Treated water is stored for distribution.

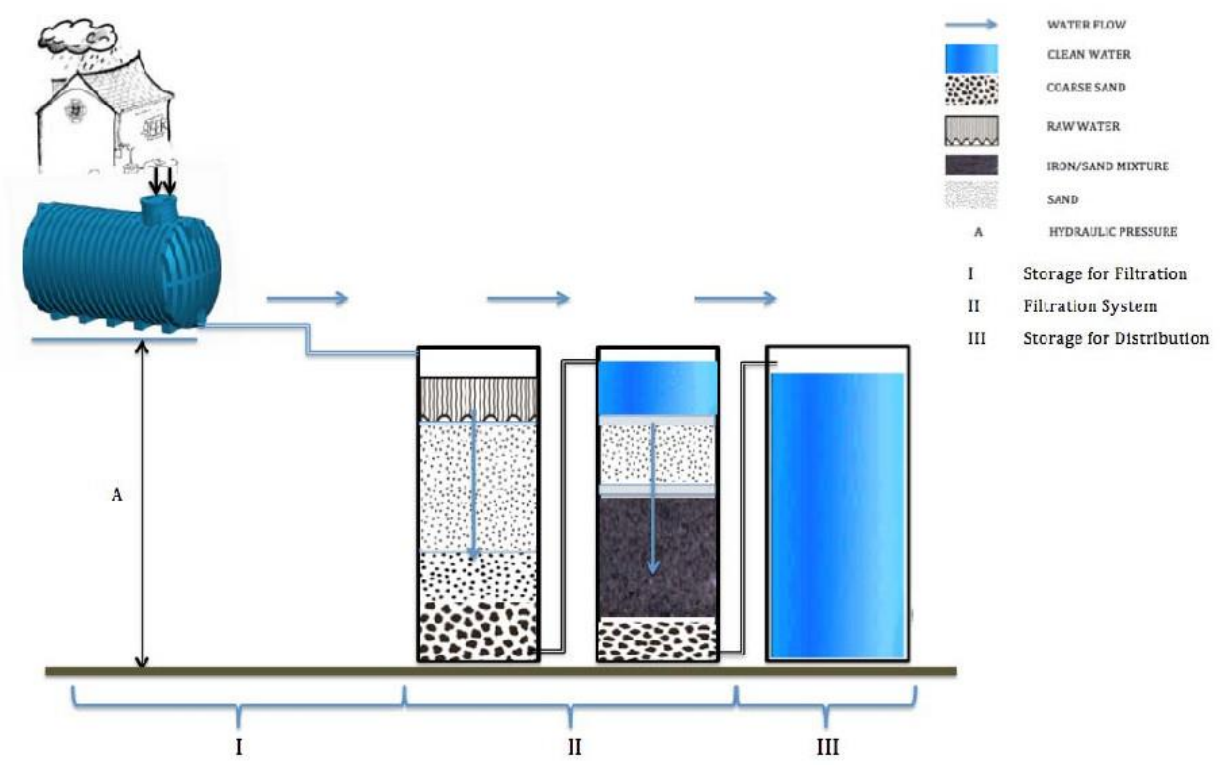

\subsection{Decentralized water supply}

Some rural locations are equipped with obsolete water supply systems with an overhead storage tank. In the developing world, however, such small scale centralized water supply systems are fraught with financial and managerial problems $[6,11,46]$. Boreholes are sometimes available for domestic water 
supply systems; however, the quality of these and all other water sources (rain, river, source) is not typically monitored $[11,48]$. Alternative decentralized technologies for the developing world should be small-scale, energy efficient, environmentally sound, and use locally available resources [7]. They should also be capable of being controlled and maintained by the local community.

\subsection{Appropriateness of decentralized water treatment systems}

Decentralized water treatment systems have three main unique advantages: (i) the ability to tailor the technology for specific contaminant species, (ii) low cost, and (iii) ability for deployment in remote locations. Ideal systems should be able to produce clean drinking water without power input, or with energy input via renewable sources such as solar power. Ideally, the system should also be constructed using local materials and use local technical labor. These requirements exclude the use of chemicals (including chlorine), particularly in low skill communities. The requirement of using endogenous or easily transferable technical skills exclude membrane technology (§ 1.2) as long as used membranes are not locally manufactured [49].

\section{Decentralized water treatment with metallic iron}

\subsection{An overview of the $\mathrm{Fe}^{0} / \mathrm{H}_{2} \mathrm{O}$ system for contaminant mitigation}

The potential utility of $\mathrm{Fe}^{0}$ filters for decentralized safe drinking water provision has been intensively investigated during the past 15 years $[14-16,18,24,26,27,50-52] . \mathrm{Fe}^{0}$ is considered an appropriate material for water treatment because it is a relatively strong reducing agent $\left(E^{0}=-0.44 \mathrm{~V}\right)$ and was applied initially to transform recalcitrant halogenated organic compounds into less toxic and/or biodegradable species [55-59]. In more recent years, $\mathrm{Fe}^{0}$ was been demonstrated as highly effective for the treatment of several other classes of substances, including aromatic nitro compounds, bacteria, heavy metals, herbicides, nitrates, pesticides, radionuclides and viruses [18,60-79]. $\mathrm{Fe}^{0}$ materials have also been used in Fenton oxidation reactions [71,72,80-82]. It appears from the overview of treatable contaminants that $\mathrm{Fe}^{0}$ might be regarded as a technology with the potential to manage all classes of contaminants (inorganic ions, organic poisons and harmful germs). This impression is supported by 
articles which reported on quantitative removal of species (e.g. 1,2-dichloroethane, dichloromethane, methylene blue, triazoles) which were proven to be not reducible by $\mathrm{Fe}^{0}$ [83-85].

The performance of $\mathrm{Fe}^{0}$ materials for water treatment has been adapted in recent years via multiple different methodologies, for a wide range of applications, including: (i) decreasing the particle size to nano-scale in order to enhance the reactivity of the material as a function of mass [86]; (ii) embedding noble bimetallic particles into the $\mathrm{Fe}^{0}$ structure in order to improve the galvanic properties of the material [87]; (iii) embedding $\mathrm{Fe}^{0}$ into appropriate porous support materials [14,48]; and (iv) embedding $\mathrm{Fe}^{0}$ with complimentary adsorbent materials [88-90]. In addition, other metallic elements (namely $\mathrm{Al}^{0}, \mathrm{Cu}^{0}, \mathrm{Sn}^{0}$ and $\mathrm{Zn}^{0}$ ) have also been tested as alternatives to $\mathrm{Fe}^{0}$ [91-95]. However, $\mathrm{Fe}^{0}$ has typically been demonstrated as superior due to its cost-effectiveness, bio-compatibility and long-term reactivity under natural conditions $[96,97]$. The presentation herein is limited to granular mm- and $\mu \mathrm{m}$ scale particles $(\mathrm{d}>215 \mu \mathrm{m})[25,98]$. Furthermore, the suitability of micron scale $\mathrm{Fe}^{0}$ particles arises from the evidence that resulting system ( $\mathrm{Fe}^{0}$ filters) must be efficient in the long term, with sub-micron scale particles becoming exhausted over relatively short timescales $[25,71,72,99,100]$.

\subsection{The nature of the $\mathrm{Fe}^{0} / \mathrm{H}_{2} \mathrm{O}$ system}

It has been demonstrated/recalled that under environmental conditions, the $\mathrm{Fe}^{0} / \mathrm{H}_{2} \mathrm{O}$ interface does not exist [101-106]. Rather, there a minimum of two interfaces: $\mathrm{Fe}^{0} / \mathrm{Fe}$-oxides and $\mathrm{Fe}-(\mathrm{hydr}) \mathrm{oxide} / \mathrm{H}_{2} \mathrm{O}$, with the material comprising a "core-shell" structure [80,81,107-112]. Moreover, the (hydr)oxide layer comprises the location for $\mathrm{H} / \mathrm{H}_{2}$ and $\mathrm{Fe}^{2+}$ formation which is driven by $\mathrm{Fe}^{0}$ corrosion. Given that the outermost (hydr)oxide layer is not typically electronic conductive extensive chemical reduction of aqueous contaminant species upon this interface does not typically occur [113]. In contrast, chemical reduction of aqueous contaminants due to chemical interactions with $\mathrm{H} / \mathrm{H}_{2}$ or $\mathrm{Fe}^{2+}$ has been demonstrated as more likely [114-118]. As a consequence $\mathrm{Fe}^{0}$ corrosion is an electrochemical reaction mediated by water $\left(\mathrm{H}_{2} \mathrm{O}\right.$ or $\left.\mathrm{H}^{+}\right)$and resulting in $\mathrm{H}_{2}$ evolution. But contaminant reduction, when it occurs, is not the primary coupled cathodic reaction $[82,112,118,119]$. 
This clarification coupled to the consideration of the formation of voluminous $\mathrm{Fe}^{0}$ corrosion products is the theoretical starting point for the design of next generation $\mathrm{Fe}^{0}$ filters $[16,17,25,98,100,120-123]$. Not considering these key issues has led to controversial reports which render the assessment of progress in designing $\mathrm{Fe}^{0}$ filters difficult. For example, in a recent article entitled "South African sands as a low cost alternative solution for arsenic removal from industrial effluents in permeable reactive barriers" Trois and Cibati [54] have demonstrated the suitability of admixing 25 or $50 \%$ (v/v) $\mathrm{Fe}^{0}$ with natural sand to treat As contamination. The title of their article is justified by the volumetric abundance of sand. But the experimental design has not tested any pure sand system (100 \% sand).

\section{Rationale for $\mathrm{Fe}^{0}$ filter design}

At present there are conflicting views with regard to the design of $\mathrm{Fe}^{0}$ filters $[8,9,54,58,88,89,90,125,126]$. In particular, the usefulness of mixing $\mathrm{Fe}^{0}$ and inert (anthracite, pumice, sand) or reactive but non-expansive $\left(\mathrm{Fe}_{3} \mathrm{O}_{4}, \mathrm{MnO}_{2}, \mathrm{TiO}_{2}\right)$ materials is still controversially discussed $[125,127,128]$. Furthermore, an empirical approach was used to screen selected operational factors like grain sizes and grain size distributions [126], grain packing [129] or the mixture of $\mathrm{Fe}_{3} \mathrm{O}_{4}$ and external $\mathrm{Fe}^{\mathrm{II}}$ solutions [88-90]. This empirical approach is certainly costly but not necessarily effective [121123]. An alternative approach is to develop the science of the system, which will serve as compass to evaluate experimental results $[25,130,131]$.

A key factor which prevents cross correlation between $\mathrm{Fe}^{0}$ water filtration studies is the absence of a standard reference material for $\mathrm{Fe}^{0}$ [132]. Accordingly, even results obtained under similar conditions are not really comparable. A methodology to compare the intrinsic reactivity of $\mathrm{Fe}^{0}$ materials has been introduced [133], and was recently revisited [132,134], however it is yet to receive universal acceptance. On the other hand, a universal design rationale for the design of $\mathrm{Fe}^{0}$ filters was presented by Noubactep and Caré $[130,131]$ and progressively revisited $[25,98,121-123]$. 
The following text provides the example of a pioneering work by Westerhoff and James [124] and enumerates the lesson, that could have been learnt from it. The discussion is limited to relevant design aspects.

\subsection{A non-exploited pioneering work}

Westerhoff and James [124] investigated nitrate removal in $\mathrm{Fe}^{0}$ packed beds both at lab and field scales. Laboratory columns $(\mathrm{V}=600 \mathrm{~mL}, \mathrm{D}=5 \mathrm{~cm}, \mathrm{~L}=30 \mathrm{~cm})$ were used. The columns were packed with two different $\mathrm{Fe}^{0}$ samples: $1636 \mathrm{~g}$ of ZVI1 $\left(6.32 \mathrm{~g} / \mathrm{cm}^{3}\right)$ and $2271 \mathrm{~g}$ of ZVI2 $\left(7.89 \mathrm{~g} / \mathrm{cm}^{3}\right)$. The field columns were packed with ZVI1. The dimensions of the field columns were: $\mathrm{V}=4000 \mathrm{~mL}, \mathrm{D}=$ $7.5 \mathrm{~cm}, \mathrm{~L}=91 \mathrm{~cm}$. While the lab columns contained $100 \% \mathrm{Fe}^{0}$, a series of field experiments implied a column with a bottom half packed with $50 \%$ sand and $50 \% \mathrm{Fe}^{0}$ to sustain the permeability. The other run had $100 \% \mathrm{Fe}^{0}$ throughout the column (Fig. 2).

Figure 2. Schematic diagrams of the common design of individual $\mathrm{Fe}^{0}$-based filters: (left) pure $\mathrm{Fe}^{0}(100 \%)$, (middle) a pre-treatment hybrid zone (e.g. $\mathrm{Fe}^{0} / \mathrm{sand}$ ) followed by $100 \%$ $\mathrm{Fe}^{0}$ and (right) a fully hybrid system. It is now established that only fully hybrid systems are sustainable because of the volumetric expansive nature of iron corrosion at $\mathrm{pH}>4.5$. 

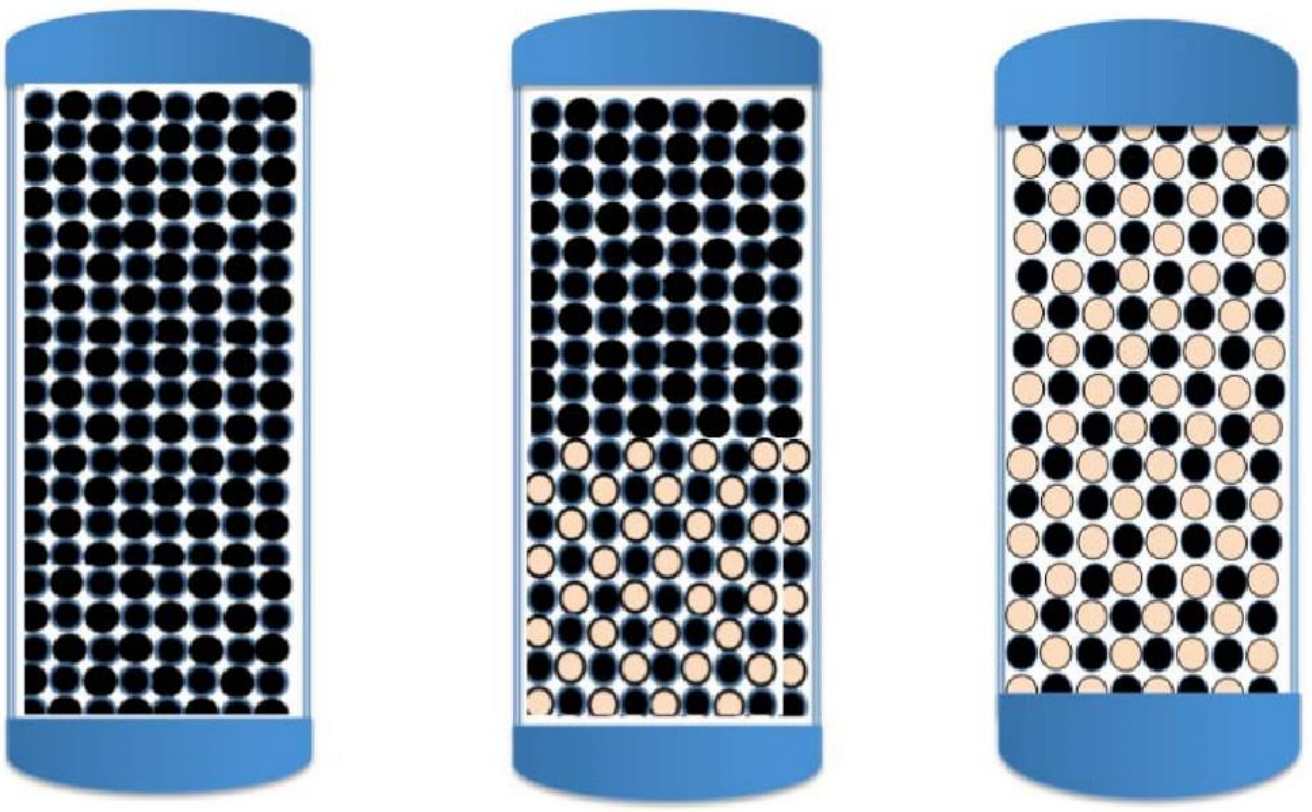

Field experiments lasted for approximately 12 months. During this period, operational problems occurred frequently in the pure $\mathrm{Fe}^{0}$ system. The most significant operational problem was a decrease in hydraulic conductivity (permeability loss) over time. Permeability loss was also documented in the hybrid $\mathrm{Fe}^{0}$ /sand system, but to a lower extent. The experiments were stopped when the residual value of the hydraulic conductivity was less than $10 \%$ of the initial value (for the hybrid $\mathrm{Fe}^{0} / \mathrm{sand}_{\text {system). }}$ Other operational problems included: (i) air entrainment, (ii) electrical power outage at the site, and (iii) cracks in reactor.

The most important results of Westerhoff and James [124] could be summarized as follows: (i) permeability loss was more pronounced under field conditions (due to a continuous supply of dissolved $\mathrm{O}_{2}$ ), (ii) there was a lack in the nitrogen mass balance (co-precipitation or enmeshment), (iii) a large difference in intrinsic reactivity was documented between the two tested $\mathrm{Fe}^{0}$ materials, and (iv) from the bottom (influent side) to the top the material in the column exhibited differential compaction 
behaviours. In particular, for the hybrid system (bottom $\mathrm{Fe}^{0} / \mathrm{sand}$, top pure $\mathrm{Fe}^{0}$ ) the three following layers were observed: (i) the bottom $10 \mathrm{~cm}$ consisted of highly cemented $\mathrm{Fe}^{0}$ and sand, (ii) the intermediate layer (still within the $\mathrm{Fe}^{0}$ /sand zone) was black in colour and was visually similar to the original $\mathrm{Fe}^{0}$ material, but the $\mathrm{Fe}^{0}$ particles were irregular in shape, and (iii) the upper pure $\mathrm{Fe}^{0}$ layer had maintained the irregular shape of the iron but had changed to a black-gray colour. Despite increased cementation in the influent zone, the same trend was observed in the pure $\mathrm{Fe}^{0}$ column.

\subsection{Lessons from the pioneering work}

The observations from the hybrid system of Westerhoff and James [124] correspond to the recent results of Miyajima [135] and Phukan [136]. These authors used a 1:1 $\mathrm{Fe}^{0}$ :sand (vol/vol) for methylene blue discoloration in column studies for 4 and 3 months respectively and observed that at the influent of the column, about $3 \mathrm{~cm}$ was brown coloured (Fig. 3) and hardly compacted, while the remaining $\mathrm{Fe}^{0} /$ sand layer was less or not compacted and black coloured. Recent works have recalled that the availability of dissolved $\mathrm{O}_{2}$ is the major factor causing particle cementation and permeability loss $[25,100,122,123]$. However, even without this 'recent' knowledge, a pragmatic approach would have consisted in comparing the density of $\mathrm{Fe}^{0}\left(7.8 \mathrm{~g} / \mathrm{cm}^{3}\right)$ and $\mathrm{Fe}$ oxides (e.g. $\beta$-FeOOH; $\left.3.6 \mathrm{~g} / \mathrm{cm}^{3}\right)[137]$. Because the volume of a filter is constant, iron corrosion is necessarily coupled with a decrease of the pore volume because in-situ generated oxides are less dense or more voluminous than parent $\mathrm{Fe}^{0}$. If $\mathrm{Fe}^{0}(\mathrm{ZVI})$ is to be transformed to Akageneite $[\beta-\mathrm{FeO}(\mathrm{OH}, \mathrm{Cl})]$, a volume of about $2 * \mathrm{~V}_{\mathrm{ZVI}}$ is necessary for the reaction to be quantitative. 
Figure 3. Photograph of a column design depicting the typical sequence of coloration described by Westerhoff and James [124]. It is seen that the entrance zone of the $\mathrm{Fe}^{0}$ /sand zone is colored brown while the upper section is black. The sand layer after the $\mathrm{Fe}^{0} / \mathrm{sand}$ zone more or less maintains his

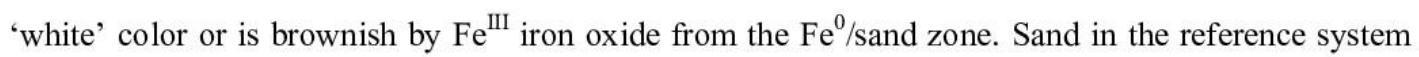
(first column) and the sand layers preceding the $\mathrm{Fe}^{0} / \mathrm{sand}$ zone is blue colored by methylene blue (see text).

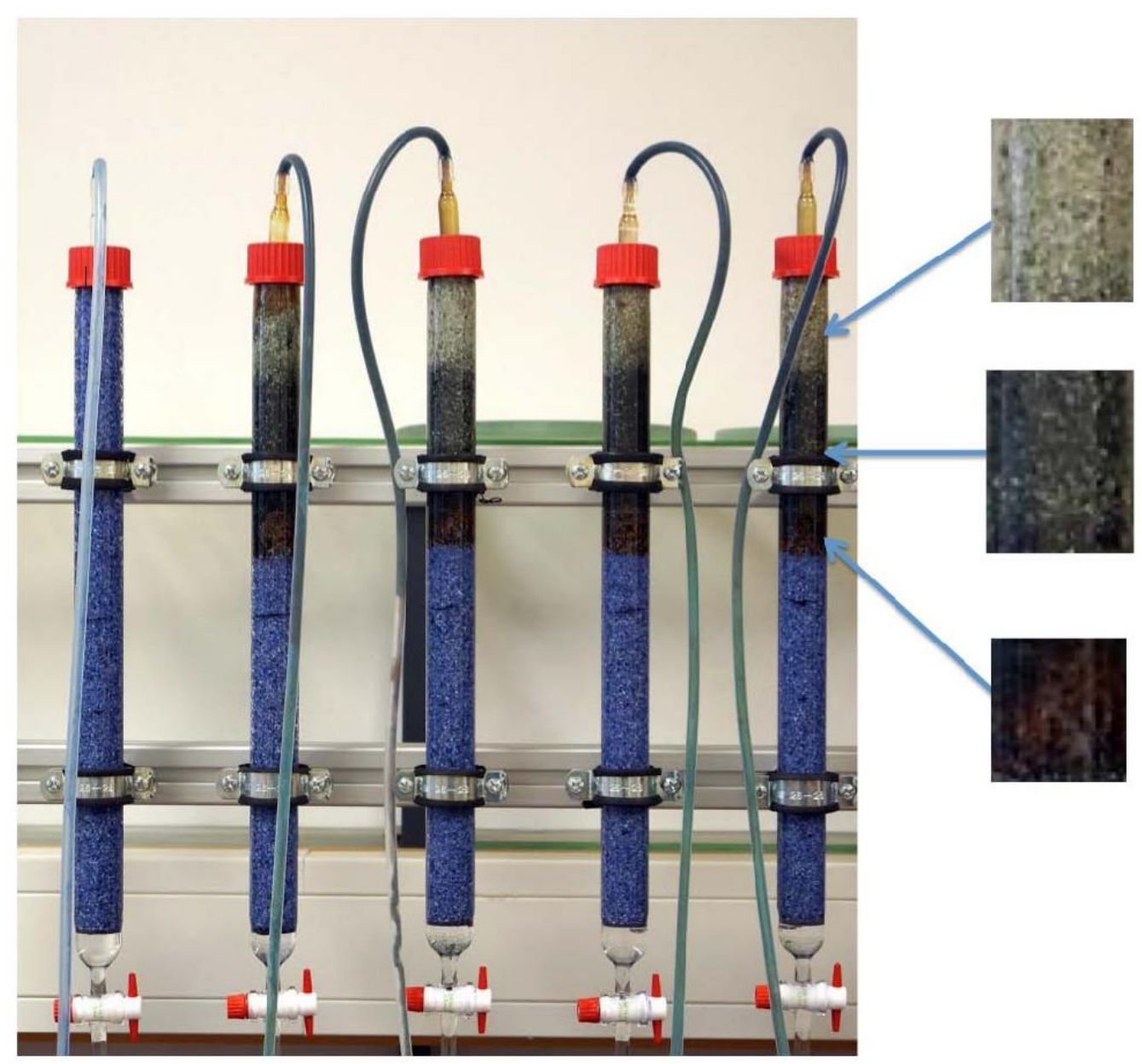

4.3. Disregarding lessons from the pioneering work 
Despite the clear message from Westerhoff and James [124] that pure $\mathrm{Fe}^{0}$ systems are not sustainable, research with pure systems has continued. For example, Ruhl et al. [125] recently tested four binary mixtures ( $\mathrm{Fe}^{0} /$ anthracite, $\mathrm{Fe}^{0} /$ gravel, $\mathrm{Fe}^{0} /$ pumice and $\mathrm{Fe}^{0}$ /sand) for their efficiency at removing Trichloroethylene (TCE) in column experiments for up to 200 d. No accompanying $\mathrm{Fe}^{0}$ system (reference system) was tested, the work of Westerhoff and James [124] was not considered for the discussion. The authors concluded that "the mixed reactive filters" are not applicable for treatment of the "tested groundwater with its indigenous microorganisms". This conclusion is erroneous for at least three reasons: (i) it is not likely that used $\mathrm{Fe}^{0}$ is depleted within $200 \mathrm{~d}$, (ii) pure $\mathrm{Fe}^{0}$ system is not tested (no operative reference), (iii) TCE removal by binary systems containing only $22 \% \mathrm{Fe}^{0}$ (w/w) was the system used to demonstrate the feasibility of $\mathrm{Fe}^{0}$ for groundwater remediation [58].

A second example showing how the results of Westerhoff and James [124] are not properly considered is presented by Huang et al. [88-90]. The authors have reported on a new efficient hybridized $\mathrm{Fe}^{0} / \mathrm{Fe}_{3} \mathrm{O}_{4} / \mathrm{Fe}^{\mathrm{II}}$ system for environmental remediation and water treatment. However, it is not clear from the related works, what makes the system sustainable and why magnetite is the suitable additive. In a system in which $\mathrm{Fe}^{\mathrm{II}}$ is in-situ generated (iron corrosion) and is suitable at the long-term, the introduction of external $\mathrm{Fe}^{\mathrm{II}}$ could be regarded as counterintuitive (LeChatelier Principle). In other words, Huang and colleagues have not yet rationalized the functionality of their system.

\subsection{Evaluation}

The two examples in $\S 4.3$ and the parameters in Tab. 1 and Tab. 2 testify that various $\mu \mathrm{m}$ and mmscale $\mathrm{Fe}^{0}$ materials have been tested as filter materials for water treatment. Most of the experiments have been performed at laboratory scale. Field experiments have been reported as well. Some $200 \mathrm{Fe}^{0}$ permeable reactive barriers $\left(\mathrm{Fe}^{0} \mathrm{PRBs}\right)$ have been installed worldwide [138-140]. Results from laboratory experiments (controlled conditions) have typically shown promising treatment efficiencies. Results from the field trials, including commercial $\mathrm{Fe}^{0}$ PRBs, have been more various. In particular, failures of $\mathrm{Fe}^{0}$ PRBs [83,141] have not been satisfactorily rationalized [122,123]. It is evident that the 
composition of contaminated waters and effluents vary to a large extent. This is also one of the reasons why comparison of published results is challenging.

Table 1. Selected operational conditions of column studies presented as examples in $\S 4$ with regard to their diversities. $\mathrm{X}$ is the contaminant of concern and 'n.s.' stands for non specified. Generally, diversities of operational conditions including the amount of $\mathrm{Fe}^{0}$ materials and their proportion in hybrid systems render fixation of reported discrepancies between studies difficult.

\begin{tabular}{|c|c|c|c|c|c|c|}
\hline \multirow[t]{2}{*}{$\mathrm{Fe}^{0} /$ solid ratio } & \multicolumn{2}{|c|}{ Column dimensions } & \multirow[t]{2}{*}{ Flow rate } & \multirow[t]{2}{*}{ Duration } & \multirow[t]{2}{*}{$\mathbf{X}$} & \multirow[t]{2}{*}{ Reference } \\
\hline & D & $\mathbf{L}$ & & & & \\
\hline (vol:vol) & $(\mathrm{cm})$ & $(\mathrm{cm})$ & $(\mathrm{ml} / \mathrm{min})$ & (days) & & \\
\hline $\mathrm{Fe}^{0}(100 \%)$ & 5.0 & 30 & variable & weeks & $\mathrm{NO}_{3}{ }^{-}$ & [124] \\
\hline $\mathrm{Fe}^{0} /$ sand $(3: 1)$ & 7.5 & 91 & n.s. & 365 & $\mathrm{NO}_{3}^{-}$ & {$[124]$} \\
\hline $\mathrm{Fe}^{0}(100 \%)$ & 7.5 & 91 & n.s. & 365 & $\mathrm{NO}_{3}^{-}$ & {$[124]$} \\
\hline $\mathrm{Fe}^{0} /$ sand $(3: 1)$ & 16 & 107 & 4.2 to 201 & 0.21 & As & {$[54]$} \\
\hline $\mathrm{Fe}^{0} /$ sand $(1: 1)$ & 16 & 107 & 4.2 to 202 & 0.21 & As & {$[54]$} \\
\hline $\mathrm{Fe}^{0}(100 \%)$ & 16 & 107 & 4.2 to 203 & 0.21 & As & {$[54]$} \\
\hline $\mathrm{Fe}^{0} /$ anthracite (n.s.) & 2.5 & 21.5 & 0.075 & 200 & TCE & {$[125]$} \\
\hline $\mathrm{Fe}^{0} /$ gravel (n.s.) & 2.5 & 21.5 & 0.075 & 200 & TCE & {$[125]$} \\
\hline $\mathrm{Fe}^{0} /$ pumice (n.s.) & 2.5 & 21.5 & 0.075 & 200 & TCE & {$[125]$} \\
\hline $\mathrm{Fe}^{0} /$ sand (n.s.) & 2.5 & 21.5 & 0.075 & 200 & TCE & {$[125]$} \\
\hline $\mathrm{Fe}^{0}(100 \%)$ & 5.1 & 15.0 & n.s. & 14 & $\mathrm{PO}_{4}{ }^{3-}$ & {$[8]$} \\
\hline $\mathrm{Fe}^{0}(100 \%)$ & 5.1 & 15.0 & 0.8 to 1.0 & 14 & As, $\mathrm{Cr}, \mathrm{Se}$ & [9] \\
\hline $\mathrm{Fe}^{0}(100 \%)$ & 5.1 & 15.0 & 0.8 to 1.0 & 14 & $\mathrm{Cd}, \mathrm{Cu}, \mathrm{Pb}$ & [9] \\
\hline
\end{tabular}


Table 2. Selected characteristic of $\mathrm{Fe}^{0}$-based filter materials used in studies presented as examples in $\S$ 4.

\begin{tabular}{llllll}
\hline \multicolumn{1}{c}{ Material } & \multicolumn{1}{c}{ Availlability } & \multicolumn{1}{c}{ Origin } & Mass & d & Ref. \\
& & & $(\mathrm{g})$ & $(\mathrm{mm})$ & \\
\hline Iron filings & scrap iron & Masterbuilders Inc. & 1636 & $0.05-0.6$ & {$[124]$} \\
Iron chips & commercial & Baker Iron & 2271 & $0.5-5.0$ & {$[124]$} \\
Iron fillings & commercial & Connelly-GPM Inc. & n.s. & $0.08-2.4$ & {$[54]$} \\
Iron fillings & commercial & Gotthart Maier & n.s. & $1.0-2.0$ & {$[54]$} \\
Granulated cast iron & commercial & Gotthart Maier & 100 & $0.3-2.0$ & {$[125]$} \\
Zero-valent iron (ZVI) & commercial & Connelly-GPM & n.s. & $0.1-2.0$ & {$[8,9]$} \\
Porous iron composite (PIC) & commercial & NA Höganäs Inc & n.s. & $0.1-2.0$ & {$[8,9]$} \\
Sulfur modified iron (SMI) & commercial & SMI_PS, Inc. & n.s. & $0.1-2.0$ & {$[8,9]$} \\
\hline
\end{tabular}

Tables 1 and 2 clearly relate the diversity among $\mathrm{Fe}^{0}$ material tested or used for environmental remediation and water treatment. Although $\mathrm{Fe}^{0}$ has been used in some 200 PBRs, little progress has been made toward characterizing the variability in reactivity among $\mathrm{Fe}^{0}$ samples from different sources [132-134,142,143].

The $\mathrm{Fe}^{0}$ literature review has also revealed that it is very hard to normalize the data from different independent studies [144,145]. In fact, despite an observed linear relationship between the first-order rate constant $\left(\mathrm{k}_{\mathrm{obs}}\right)$ and the specific surface area of $\mathrm{Fe}^{0}$, the introduction of the $\mathrm{k}_{\mathrm{SA}}$-concept (surface area normalized rate constant) did not enable comparison of experiments obtained by different $\mathrm{Fe}^{0}$ types. There are several reasons for this including: (i) the intrinsic reactivity of tested $\mathrm{Fe}^{0}$, (ii) the various physical properties (shape, size, specific surface area) of tested $\mathrm{Fe}^{0}$, (iii) the proportion of $\mathrm{Fe}^{0}$ in the system, and (iv) the solution $\mathrm{pH}$ and the redox potential. Furthermore, a standard protocol is 
missing which might enable the comparison of $\mathrm{Fe}^{0}$ materials based on their treatment efficiency for a given volume of water, with a given level of contamination, and flow through the $\mathrm{Fe}^{0}$-based filter at a certain flow velocity. Only under such defined conditions could the complexity of processes occurring in $\mathrm{Fe}^{0} / \mathrm{H}_{2} \mathrm{O}$ systems be properly addressed.

Summarizing the $\mathrm{Fe}^{0}$ literature, it is observed that despite 20 years of intensive research and numerous field scale treatment facilities, the explanations for contaminant removal from water by $\mathrm{Fe}^{0}$ are is still in its infancy [25]. Drawbacks have not been reported to a large extent, the attention seems to be focused on success stories $[118,122,123]$. The use of $\mathrm{Fe}^{0}$ as filter materials for water treatment is necessarily connected to two major 'drawbacks' [41]: (i) 'reactivity loss' or non linearity of $\mathrm{Fe}^{0}$ corrosion, and (ii) permeability loss resulting from the loss of interconnectivity of the initial pore space (in-situ generation of 'cementing' agents). In essence, both 'reactivity loss' and permeability loss are inherent to $\mathrm{Fe}^{0}$ filtration for water treatment. This implies that both apparent 'disadvantages' have occurred (to different extents) at success sites. Therefore, the way forward is further systematic research. Such a collaborative research path has recently been initiated in our laboratories. Achieved results are summarized in the following section.

\subsection{Rationally designing $\mathrm{Fe}^{0}$ filters}

A critical literature review ( $§ 4.1$ through 4.4 ) has revealed unsatisfactory aspects related to the design of $\mathrm{Fe}^{0}$ filters. It has also shown that, based on Westerhoff and James [124], the $\mathrm{Fe}^{0}$ system design could have been given more attention during the past 10 years. This approach would have been beneficial for the procurement of new systems as well as the modification and operation of existing systems (e.g. three-pitcher household filter). It is of vital importance that these systems are designed according to the intrinsic properties of $\mathrm{Fe}^{0}[101,104,108,109]$, and known principles for designing conventional granular filters [146-148]. Moreover, the intrinsic properties of contaminants should be considered because classifications like "organic contaminants (e.g., dyes, pesticides, and pharmaceuticals/drugs)" or "industrial organic wastes (e.g., phenols and aromatic amines)" say nothing about the chemical reactivity or the affinity of the species of concern for the $\mathrm{Fe}^{0} / \mathrm{H}_{2} \mathrm{O}$ system. 
The realization that aqueous contaminant removal in the presence of $\mathrm{Fe}^{0}\left(\mathrm{Fe}^{0} / \mathrm{H}_{2} \mathrm{O}\right.$ system) is not a property of the reduction by $\mathrm{Fe}^{0}$ but a characteristic of corroding $\mathrm{Fe}^{0}[115,149-151]$ was decisive for the rational design of $\mathrm{Fe}^{0}$ filters. In other words, contaminant removal is not mediated by reductive degradation or reductive precipitation but by the interactions between dissolved contaminants and (i) primary $\left(\mathrm{Fe}^{\mathrm{II}}, \mathrm{H} / \mathrm{H}_{2}\right)$, secondary $\left(\mathrm{Fe}^{\mathrm{II}} / \mathrm{Fe}^{\mathrm{III}}\right.$-hydroxides/oxides) and tertiary ( $\mathrm{Fe}^{\mathrm{III}}$-hydroxides/oxides) products of $\mathrm{Fe}^{0}$ oxidative dissolution. Here, $\mathrm{Fe}^{0}$ is oxidized by water $\left(\mathrm{H}^{+}\right.$or $\left.\mathrm{H}_{2} \mathrm{O}\right)$. This observation corresponds to reports of several researchers [152-155] with the subtle but decisive difference that reduction (if applicable) is subordinated to adsorption, co-precipitation and size-exclusion. Clearly, under experimental conditions, there is reduction in the presence of $\mathrm{Fe}^{0}$ (in $\mathrm{Fe}^{0} / \mathrm{H}_{2} \mathrm{O}$ systems) but not by $\mathrm{Fe}^{0}$ (no direct reduction).

The finding that direct reduction (reduction by $\mathrm{Fe}^{0}$ ) is of secondary importance for the process of contaminant removal in $\mathrm{Fe}^{0} / \mathrm{H}_{2} \mathrm{O}$ systems implies that observed reduction was mediated by primary corrosion products $\left(\mathrm{Fe}^{\mathrm{II}}\right.$ and $\left.\mathrm{H} / \mathrm{H}_{2}\right)$ and that contaminants are removed by adsorption, co-precipitation and size-exclusion. This finding was followed by a theoretical work discussing the suitability of using hybrid systems instead of pure $\mathrm{Fe}^{0}$ layers $[120,130,131]$. Results challenged the still popular view, that mixing $\mathrm{Fe}^{0}$ with non reactive materials (e.g. pumice, sand) is a chance to save $\mathrm{Fe}^{0}$ costs while satisfying width requirements $[125,127,128]$. Rather, it is demonstrated that mixing $\mathrm{Fe}^{0}$ and a non expansive aggregate is a prerequisite for sustainable $\mathrm{Fe}^{0}$ filters, the most sustainable system containing $25 \% \mathrm{Fe}^{0}(\mathrm{v} / \mathrm{v})[98,100,121]$. These theoretical results have been experimentally validated $[135,156-$ 159].

The ion-selective nature of $\mathrm{Fe}^{0} / \mathrm{H}_{2} \mathrm{O}$ systems was also demonstrated using methylene blue (MB) as operational indicator $[135,156,158,159]$. The suitability of MB for this purpose arises from the fact that MB (cationic) has a very low affinity for iron hydroxides/oxides $\left(\mathrm{pH}_{\mathrm{pzc}}>6.0\right)$ covering the surface of $\mathrm{Fe}^{0}$ in $\mathrm{Fe}^{0} / \mathrm{H}_{2} \mathrm{O}$ systems. Under these conditions, the most reactive system is the one quantitatively producing iron oxides, or the one in which "early" MB breakthrough is observed [132]. From Fig. 3, a 
summary of the behavior of the $\mathrm{Fe}^{0}$ /sand/MB system can be read as: (i) negatively charged sand is an excellent adsorbent for $\mathrm{MB}$, (ii) in the $\mathrm{Fe}^{0} /$ sand zone, $\mathrm{MB}$ discoloration is first 'disturbed' by $\mathrm{Fe}^{\mathrm{II}}$ and $\mathrm{Fe}^{\mathrm{III}}$ ions (concurrence for negatively charged sand surface), and later by ion oxides, in-situ coated on sand $[135,158]$, (iii) the preferential flow created in the $\mathrm{Fe}^{0} / \mathrm{sand}$ zone makes the sand layer upwards not fully available for MB discoloration (no blue coloration).

This hypothesis from MB discoloration was further confirmed/validated using two anionic dyes: Orange II and reactive red 120 [136,160]. Using MB as operative indicator has solved the long lasting problem of reducing the experimental duration while achieving reliable results $[113,161,162-166]$. Using up to $100 \mathrm{~g} \mathrm{Fe}^{0}$ packed in fixed beds, it is clearly demonstrated that reliable results could be obtained only after 2 months. This should be regarded as the absolute minimal duration of a column study. Tab. 1 recalls that larger $\mathrm{Fe}^{0}$ amounts have been typically used for sometimes shorter experimental duration.

The demonstration that the $\mathrm{Fe}^{0} / \mathrm{H}_{2} \mathrm{O}$ system is ion-selective and the evidence that only hybrid systems are sustainable are the cornerstones for the design of better laboratory and field $\mathrm{Fe}^{0}$ filters. This issue is addressed in the following section. The ion-selective nature of the $\mathrm{Fe}^{0} / \mathrm{H}_{2} \mathrm{O}$ system suggests that available literature on the interaction of iron oxides/hydroxides with contaminants should be considered in designing $\mathrm{Fe}^{0}$ filters. In other words, classifications like "heavy metals", "industrial organic wastes", "organic contaminants" or "personal care products" are not really useful. As an example, recent review on dyes adsorptive removal [167,168] reveals that the science of dye interaction with metal oxides (including iron oxides) dates back to the years 1951-1970. Since then, it was established that there are three classes of dye: anionic, cationic and non-ionic, behaving differently with various metal oxides and hydroxides [169-176]. The main open question for the $\mathrm{Fe}^{0}$ research is how to correlate available knowledge on contaminant adsorption on iron oxides and the fact that these adsorbents are progressively in-situ generated in $\mathrm{Fe}^{0} / \mathrm{H}_{2} \mathrm{O}$ systems. A further question would be when 
the generation of iron oxides stops or when available $\mathrm{Fe}^{0}$ will be completely exhausted in the filters. Answering this question would enable the prediction of service life of $\mathrm{Fe}^{0}$ filters.

\section{Designing $\mathrm{Fe}^{0}$ filters for on-site water treatment}

The $\mathrm{Fe}^{0}$ amount necessary to treat a given volume of water depends on five main parameters: (i) the nature of the contaminant (solubility, affinity to iron corrosion products), (ii) the contamination level, (iii) the $\mathrm{Fe}^{0}$ intrinsic reactivity, (iv) the water flow velocity and the resulting interaction time as well as (v) the water chemistry (including $\mathrm{pH}$ value and hardness). The first intrinsic issue associated with $\mathrm{Fe}^{0}$ is that its physical structure and chemistry constantly changes during aqueous corrosion. This inherent difficulty makes stoichiometric determinations between $\mathrm{Fe}^{0}$ and aqueous contaminant species extremely challenging, i.e. it is difficult to define operational parameters such as adsorption capacity which is a trivial process for non-reactive adsorbents [13,177-179].

\subsection{Modular $\mathrm{Fe}^{0}$ filter design}

The present paper intends to provide rationale for the design of a pilot plan in which a $\mathrm{Fe}^{0}$ filter operates as an independent treatment unit, similar to the pioneering work by Westerhoff and James [124]. The scientific basis for this design is summarized in Noubactep et al. [121] and Rahman et al. [98]. The basic treatment system should consist of a modular series of treatment processes and includes in the following sequence (i) roughing filters, (ii) slow sand filters (SSF) and (iii) $\mathrm{Fe}^{0} / \mathrm{sand}$ filters. $\mathrm{Fe}^{0} / \mathrm{sand}$ filters could also be followed by SSF or iron removing filters for maximum effluent water quality. As stated above, the goal is to build a module for the treatment of drinking water for 100 people. The World Health Organization estimates that the average daily water requirement for drinking and cooking per person is $7.5 \mathrm{~L}$, which equates to $750 \mathrm{~L}$ for 100 persons. The system presented herein will therefore be designed to treat a minimum of $1000 \mathrm{~L}\left(1 \mathrm{~m}^{3}\right)$ water per day.

It should be explicitly stated that slow sand filter (SSF) are currently more or less successfully used for drinking water provision at household and small community levels $[54,120]$. However, sand itself does very little in cleaning water contaminated with organic and inorganic species (chemical contamination) 
and the removal of biological contamination is not resolved to this day. In essence, sand. filters in study [180] work only when the groundwater to be cleaned is $\mathrm{Fe}^{\mathrm{II}}$-rich. This $\mathrm{Fe}^{\mathrm{II}}$ is oxidized to $\mathrm{Fe}^{\mathrm{III}}$ and derived $\mathrm{Fe}^{\mathrm{III}}$-(hydr)oxides in-situ coat sand grains making it suitable for the removal of contaminants such as As [50]. The effort presented herein could be regarded as an attempt to improve SSF.

\subsection{Appropriateness of $\mathrm{Fe}^{0}$ filters}

An implicit shortcoming for $\mathrm{Fe}^{0}$ /sand filters is that $\mathrm{Fe}^{0}$ corrosion by natural water can not be accelerated 'on request'. Positively tested approaches to accelerate $\mathrm{Fe}^{0}$ corrosion include (see $\S 4.1$ ) (i) the reduction of the particle size down to nano-scale [86], (ii) using porous materials $[8,9,14]$, (iii) using electro-dissolution and internal electrolyse [27,181], (iv) using oxidizing agents like $\mathrm{H}_{2} \mathrm{O}_{2}$ or $\mathrm{O}_{3}$ [24,52], (v) using multi-metallic systems, including sulfur modified iron [8,9,27,69], (vi) using minerals with the potential to act as $\mathrm{Fe}^{\mathrm{II}}$ scavenger $\left(\mathrm{MnO}_{2}\right)[159,182]$, and (vii) controlling the $\mathrm{O}_{2}$ level [124]. Of these approaches, only those implying no chemicals and no technical skills are suitable for small communities (in the developing world). These are: using porous materials, using multi-metallic systems, using minerals like $\mathrm{MnO}_{2}$, controlling the $\mathrm{O}_{2}$ level and combinations thereof.

In preliminary studies, the initial water flow rate should correspond to that of a slow sand filter. This initial flow rate will be stepwise increased to take the maximum advantage of microbial processes in the SSF and chemical and physical processes in the $\mathrm{Fe}^{0}$ /sand filters.

\subsection{Improving available designs}

A compilation of literature data $[24,121,124,183]$, suggests that an effective pilot system is likely to comprise: (i) a series of polyethylene tanks ( $\geq 1200 \mathrm{~L})$ installed for instance beside a municipal water treatment plant (raw water storage), (ii) a series of roughing filters, (iii) a series of slow sand filter (SSF), (iv) a series of $\mathrm{Fe}^{0} /$ sand filters, eventually (v) a series of filters for the removal of Fe escaping from the $\mathrm{Fe}^{0}$ /sand filters, and (vi) a second series of polyethylene tanks to collect and store drinking water. The number of filters in each series depends on the quality of the raw water and the quality of potable water to be delivered to the community. In a pilot study, after each treatment step, the quality of water should be monitored. 
As a starting point, a modified field column of Westerhoff and James [124] can be applied: $\mathrm{V}=4400$ $\mathrm{mL}, \mathrm{d}=7.5 \mathrm{~cm}, \mathrm{~L}=100 \mathrm{~cm}$. Each $\mathrm{Fe}^{0} / \mathrm{sand}$ column comprises a $70 \mathrm{~cm}$ reactive layer sandwiched between $2 * 15 \mathrm{~cm}$ gravel or fine sand. Roughing filters and slow sand filters are filled in the same manner but the reactive layer $(70 \mathrm{~cm})$ is replaced by gravel and fine sand respectively (Fig. 4).

Figure 4. Concept for the configuration of multi-barrier water treatment systems: (up) the sustainable biochar-based system, and (down) a comparable $\mathrm{Fe}^{0}$-based system. Adapted from Kearns [184]. A comparison of the cleaning efficiency of any material to $\mathrm{Fe}^{0}$ should be performed by replacing the $\mathrm{Fe}^{0}$ /sand unit by the corresponding unit(s) containing the material of concern. This approach will enable the extension of the multi-barrier concept for efficient water treatment.

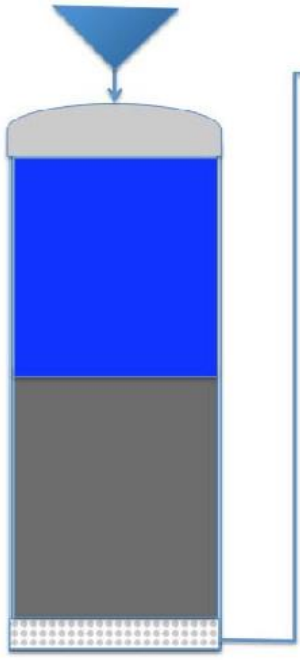

Roughing filter

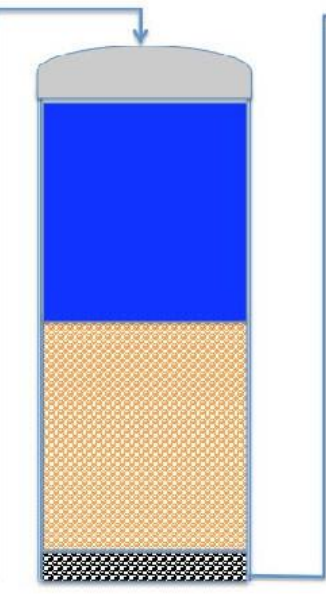

biosand filter

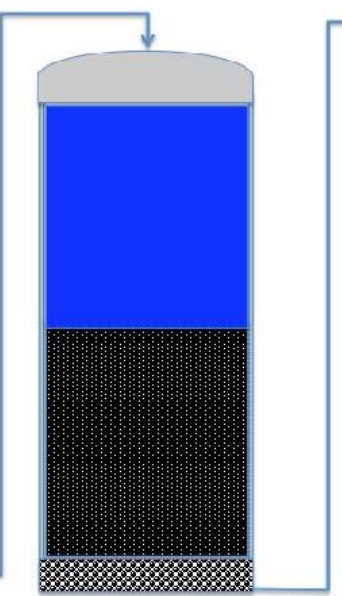

biochar filter

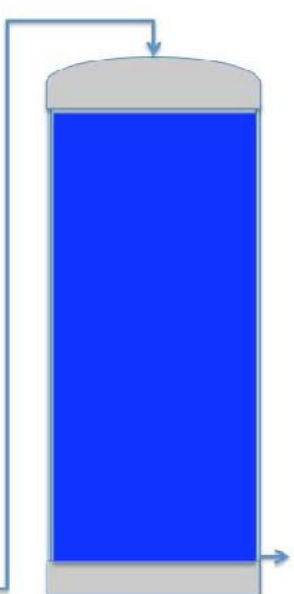

treated water 
Water 2014, 6

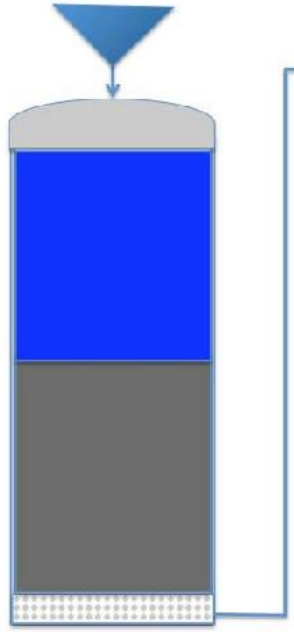

Roughing filte

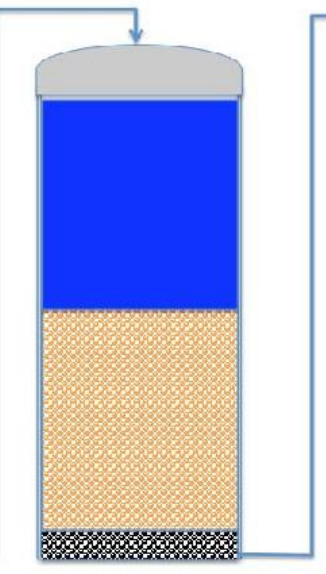

biosand filter

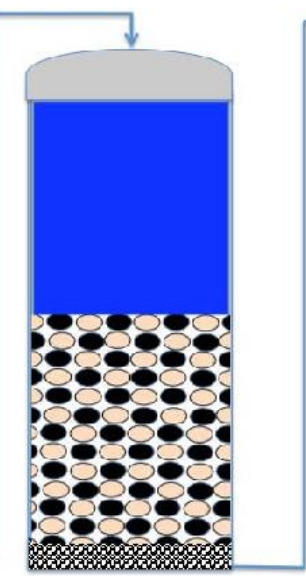

$\mathrm{Fe}$ / Sand filter

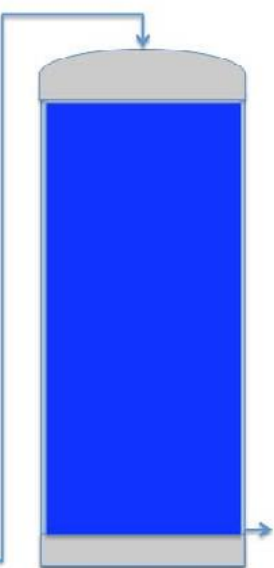

treated water 


\subsection{Ways to efficient $\mathrm{Fe}^{0}$ on-site water treatment plants}

Section 4.4 has demonstrated that a minimum of six variables $\left(\mathrm{Fe}^{0}\right.$ intrinsic reactivity, $\mathrm{Fe}^{0}$ shape and size, $\mathrm{Fe}^{0}$ content (amount and proportion), solution $\mathrm{pH}$ and the redox potential) have been shown to have an important impact on the decontamination efficiency of $\mathrm{Fe}^{0} /$ sand filters. This makes comparisons and correlation of available data difficult. However, a profound analysis of the fundamental reactions involved, together with some recently obtained design criteria, brings out a number of important considerations which may simplify design efforts. They can be summarized as (i) use only volumetric $\mathrm{Fe}^{0}$ ratios $\leq 50 \%$, (ii) characterize the intrinsic reactivity of used $\mathrm{Fe}^{0}$, (iii) use as less $\mathrm{Fe}^{0}$ as necessary for reliable observations, and (iv) avoid too short experimental durations.

Testing $\mathrm{Fe}^{0}$ materials at pilot scale (a given model water) can be resumed in the following: (i) test several well-characterized $\mathrm{Fe}^{0}$ materials, (ii) test several $\mathrm{Fe}^{0} /$ sand ratios $\left(\mathrm{Fe}^{0}<50 \%\right)$, for a given $\mathrm{Fe}^{0}$ material and $\mathrm{Fe}^{0} / \mathrm{sand}$ ratio, (iiia) test the number of each unit for satisfactorily water treatment, (iiib) insert wood charcoal units before $\mathrm{Fe}^{0}$ /sand units, (iv) partly or totally replace sand by porous materials including: anthracite, gravel, $\mathrm{MnO}_{2}$ and pumice.

At each site and for each design water samples should be analysed on a weekly basis. Beside the concentrations of relevant contaminants (including pathogen indicators), the Fe level, the turbidity and the $\mathrm{pH}$ values should also be monitored. The hydraulic conductibility should also be recorded. This ambitious program implies the equipment of water laboratories wherever pilot scales are planned: ideally in any country water contamination is potentially a problem. Clearly the whole developing world should be equipped by good water laboratories. At the end of the field operation, the $\mathrm{Fe}^{0} / \mathrm{sand}$ column should be dismantled and thoroughly characterized. In this effort the seminal work of Westerhoff and James [124] can be used as guide.

\subsection{Comparing $\mathrm{Fe}^{0}$ filters to other technologies}

The constancy that the nature of $\mathrm{Fe}^{0}$ filters has not been properly considered in filter design efforts implies the necessity to revisit the approach to (i) compare $\mathrm{Fe}^{0}$ and other affordable filter materials for water treatment $[185,186]$, and (ii) implement $\mathrm{Fe}^{0}$ in a combination of treatment methods for more 
efficient systems $[187,188]$. The presentation above has already shown that $\mathrm{O}_{2}$ scavengers including SSF should precede $\mathrm{Fe}^{0}$ /sand filters. The situation of multiple contaminant mixtures which may not be efficiently treated by a single technology [189] is an opportunity to compare $\mathrm{Fe}^{0}$ filtration to other available affordable filtration systems [190] and shape multi-barrier systems involving $\mathrm{Fe}^{0}$ filters. Contaminants possess different properties with respect to adsorptive behaviour, degradation potential, molecular size, solubility and surface charge [191]. $\mathrm{Fe}^{0}$ filters are ionic selective in nature because at neutral $\mathrm{pH}$ values, the surface of iron oxides is positively charged [160,191]. This means that negatively charged contaminants are readily removed in $\mathrm{Fe}^{0}$ filters. Because multiple contaminant mixtures may contain positively charged species as well, it is important to comparatively test $\mathrm{Fe}^{0}$ and other materials under the same operational conditions. Relevant filter materials include activated carbons, bark, bio-carbons (biochar), wood charcoal, calcareous shale, chitin, chitosan, commercial ion exchangers, dairy manure compost, dolomite, fly ash, lignite, limestone, olivine, peat, rice husks, steel slag materials, vegetal compost, yeast and zeolites [190,192].

Comparing $\mathrm{Fe}^{0}$ filters to other filtration systems is resumed in replacing $\mathrm{Fe}^{0} / \mathrm{sand}$ units in a treatment train as described in $\S 5.3$ by a unit filled by the material to be tested ( $70 \mathrm{~cm}$ per unit). Here the materials are not compared based on their mass, their chemical reactivity, but on the efficiency of a 70 $\mathrm{cm}$ packed filter. Results of such experiment will give strong basis for the design of multi-barrier systems involving $\mathrm{Fe}^{0} /$ sand units.

\subsection{Economic considerations}

The economy of $\mathrm{Fe}^{0} /$ sand filters has already been discussed. According to Gottinger et al. [24,52], $\mathrm{Fe}^{0} /$ sand filtration for removal of $\mathrm{As}$ and $\mathrm{U}$ is economically feasible for small-communities. The total treatment cost is less than $\$ 0.01 / \mathrm{L}$ water in their modular treatment train, including filter installation, media, operation and maintenance, and disposal. The system presented herein should be less expensive because no ozonation and no aeration are needed. 
The mass of iron needed for each $\mathrm{Fe}^{0} /$ sand unit can be estimated using the data of Westerhoff and James [124]. Here, $2271 \mathrm{~g}$ of the densest $\mathrm{Fe}^{0}$ material fill $600 \mathrm{~mL}$ with a porosity of $40 \%$. Assuming the same porosity, the volume corresponding to $\mathrm{L}=70 \mathrm{~cm}$ reactive zone can be calculated using Eq. 1 :

$$
\mathrm{V}=\mathrm{L} . \mathrm{S}=\pi * \mathrm{~L}^{*} \mathrm{D}^{2} / 4
$$

where $\mathrm{S}=\pi^{*} \mathrm{D}^{2} / 4$ is the cross section of the column with a diameter $\mathrm{D}=7.5 \mathrm{~cm}$. The calculations yield a volume of $3094 \mathrm{~cm}^{3}$ or $3094 \mathrm{~mL}$. The corresponding $\mathrm{Fe}^{0}$ mass is given by the rule of proportion like (Eq. 2):

$$
\mathrm{m}=3094 * 2271 / 600
$$

The calculations yield a mass of $11710 \mathrm{~g}$ or $11.71 \mathrm{~kg}$ of $\mathrm{Fe}^{0}$ for a $100 \% \mathrm{Fe}^{0}$ unit. For a $1: 1 \mathrm{Fe}^{0}$ to sand mixture, just 5.86 or about $6 \mathrm{~kg}$ of $\mathrm{Fe}^{0}$ is need. If it is further supposed that $4 \mathrm{Fe}^{0} / \mathrm{sand}$ units will be needed and the system will operate for one year, then a 100-inhabitant-community may needed just 24 $\mathrm{kg} \mathrm{Fe}^{0}$ for one year.

In addition, having good water and the know-how to produce more at low cost or low money expense, small communities have the possibility to commercialize exceeding water. That are some $250 \mathrm{~L}$ per day for the model community of this study that can be bottled and offered to consumers. In other words, $\mathrm{Fe}^{0} /$ sand filters are not only affordable for communities in need; they are also a potential source of income. Business models for commercialization of treated water in the developing world have already been presented [7].

\subsection{Implementation of $\mathrm{Fe}^{0}$-based water treatment plants}

There are important aspects of $\mathrm{Fe}^{0}$ filter's implementation that should be pointed out before sending a construction crew to the field. The maintenance of the $\mathrm{Fe}^{0}$ filters is not addressed herein as it will be considered during pilot testing under real life conditions. In recent years, there have been numerous pilot plant testing for water filters, partly involving $\mathrm{Fe}^{0}[24,26,27,52,124,184,193-195]$. Construction materials (ceramic, concrete, metallic, plastic) are numerous and include: (i) plastic tanks (e.g. polyetheylene), (ii) modified shipping container, (iii) ferro-cement tanks and (iv) PVC tubing. $\mathrm{Fe}^{0}$ materials can be commercially obtained. In general, manufacturing of $\mathrm{Fe}^{0}$ filters is comparable to other 
existing filters, making it à priori a feasible technology. This section will enumerate the materials used by Kearns [195] and adaptable for $\mathrm{Fe}^{0}$ filters.

\subsubsection{Siting}

Water is ideally moved by gravity. The water system is sited at lower elevation than the source water and at higher elevation than the location(s) where treated water will be used. This circumstance enables completely passive operation of the treatment system and very simple control using only a float valve. When water is withdrawn from the storage tank (Fig. 4a) the water level in the system drops, opening the float valve. When the system is full, the float valve closes.

\subsubsection{Containment}

The $\mathrm{Fe}^{0}$-based water treatment system presented herein is an open architecture which could be constructed, modified, adapted and improved on a site-specific basis. Filters containers can be locally built, for example from stackable prefabricated concrete rings commonly used for tank construction. Commercially available plastic tanks can be also modified and used. Appropriately skilled masons can construct custom ferro-cement tanks. In this case the dimensions should enable facile filling of filter media and routine maintenance including the removal/replacement of all materials.

Some cover material (lid) should be used to exclude sunlight and inhibit the growth of photosynthetic microorganisms (algae, cyanobacteria) in the system. Tank tops should be wrapped in fine mesh screening to prevent entrance of insects, bird droppings, leaves and bits of debris, etc. into the system.

\subsubsection{Plumbing}

PVC pipe is ubiquitous and cheap in most locations. The most suitable diameter for most connections to and from the water system and between the tanks should be used. Plumbing in the bottom of filter tanks should be protected from physical damage and blockage by under drains made from rock and coarse gravel at least $20 \mathrm{~cm}$ in depth.

\subsubsection{Filter materials}

Standard gravel $(1.0-4.0 \mathrm{~cm})$ should be used for the roughing filter. Standard fine sand $(0.15-0.35$ $\mathrm{cm})$ should be used for the sand filter [194]. The sand to be used in the reactive zone ( $\left.\mathrm{Fe}^{0} / \mathrm{sand}\right)$ should 
be coarser (e.g. $0.5-2.0 \mathrm{~cm}$ ) and of comparable particle size. $\mathrm{Fe}^{0}$ should be abundantly available and selected for its appropriate reactivity.

\subsubsection{Implementation Plan}

Whatever materials will be tested at pilot scale, there is the possibility to find cheaper options. A pilot plan should be able to be implemented in a single phase. Firstly the tanks, piping materials and other equipment listed need to be sourced, bought and transported to the pilot site. The transport can be made by any common trailer truck. Once at the site, it will be relatively simple to build, operate and monitor the $\mathrm{Fe}^{0}$-based plant for at least 6 months.

\section{Concluding remarks}

The need for a scientific-based approach to design and evaluate the efficiency of $\mathrm{Fe}^{0}$ filters is corroborated in this study. The urgency of such a consensual approach is evident as it is established herein that required knowledge (science of aqueous iron corrosion) is available, but has not been considered in the right way. All is needed is a systematic holistic approach enabling the characterization of aqueous iron corrosion as influenced by the water chemistry, including the $\mathrm{pH}$ value, the presence of contaminants and co-solutes. The present study intends to create/initiate a synergy among researchers who are working for more efficient $\mathrm{Fe}^{0}$ filtration systems for decentralized water treatment. The adoption or at least the general consideration of fundamental aspects presented herein would accelerate the understanding of the operating mode of $\mathrm{Fe}^{0}$ filters and thus, outline the strengths and limitations of this still innovative, but potentially highly efficient technology.

This study specifically restricted its attention to aspects relevant for filter design and the evaluation of their performance in long-term experiments, in particular at pilot scale. The specific objectives of the paper were to make recommendations based on the current state of the science concerning (i) aqueous iron corrosion and (ii) contaminant removal by iron oxides/hydroxides in the environment. The achievement can be summarized in a number of questions, including the following: (i) Which $\mathrm{Fe}^{0}$ materials are suitable for water treatment (intrinsic reactivity, porosity, size)? (ii) Which level of 
dissolved $\mathrm{O}_{2}$ is needed for sustainable systems? (iii) How can one warrant the needed level of dissolved $\mathrm{O}_{2}$ ? (iv) What is the general filter design (depth of filter, layering arrangement with particles of different sizes, compaction of the media during construction)? (v) Is it feasible to classify chemicals according to their affinities to the $\mathrm{Fe}^{0} / \mathrm{H}_{2} \mathrm{O}$ system? (vi) What types of data are needed for the evaluation of chemicals (molecular size, molecular weight, solubility)? (vii) How does one proceed when data for critical inputs are missing (molecular size)? (viii) Are transformation half-lives of any realistic significance in assessing the relative removal efficiency of species in $\mathrm{Fe}^{0} / \mathrm{H}_{2} \mathrm{O}$ system? (ix) Which other treatment units, beside sand filters (e.g. activated carbons) are necessary to optimize the efficiency of the system (on a site specific basis)? and (x) What is the optimal frequency of filtration events (intermittent filters).

If future experiments are performed with these ten questions in mind, it will soon be possible to establish the science of ' $\mathrm{Fe}^{0}$ for environmental remediation' based on the science of aqueous iron corrosion and knowledge on the interactions of iron oxides and hydroxides with aqueous species.

\section{Acknowledgments}

Thanks are due to Sabine Caré (Université ParisEst/France); Emmanuel Chimi (Université Douala/Cameroon); Mohammad A. Rahman (Leibniz Universität Hannover/Germany) and Paul Woafo (Université Yaoundé 1/Cameroon) and for fruitful collaboration on investigating the evolution of the porosity of iron filtration systems. Gerhard Max Hundertmark is acknowledged for technical support. We acknowledge support by Deutsche Forschungsgemeinschaft and Open Access Publishing Fund of Georg-August-Universität Göttingen.

\section{Author Contributions}

The text of this article was written by Chicgoua Noubactep and Richard Crane with contributions from Raoul Tepong-Tsindé, Achille Nassi and Hans Ruppert. Raoul Tepong-Tsindé conducted background research on the design of a pilot plan. 


\section{Conflicts of Interest}

The authors declare no conflict of interest.

\section{References and Notes}

1. Shannon, M.A.; Bohn, P.W.; Elimelech, M.; Georgiadis, J.G.; Marinas B.J.; Mayes, A.M. Science and technology for water purification in the coming decades. Nature 2008, 452, 301310.

2. Mohapatra, M.; Anand, S.; Mishra, B.K.; Giles, D.E.; Singh, P. Review of fluoride removal from drinking water. J. Environ. Manage. 2009, 91, 67-77.

3. Peter-Varbanets, M.; Gujer, W.; Pronk, W. Intermittent operation of ultra-low pressure ultrafiltration for decentralized drinking water treatment. Water Res. 2012, 46, 3272-3282.

4. Slaughter, S. Improving the sustainability of water treatment systems: Opportunities for innovation. Solutions 2010, 1, 42-49.

5. Tellen, V.; Nkeng, G.; Dentel, S. Improved filtration technology for pathogen reduction in rural water supplies. Water 2010, 2, 285-306.

6. Grady, C.; Younos, T. Bottled water technology and its global ramifications: an overview. Int Water Technol. J. 2012, 2, 185-194.

7. Sima, L.C.; Elimelech, M. More than a drop in the bucket: decentralized membrane-based drinking water refill stations in southeast Asia. Environ Sci Technol. 2013, 47, 7580-7588.

8. Allred, B.J.; Racharaks, R. Laboratory comparison of four iron-based filter materials for drainage water phosphate treatment. Water Environ. Res. 2014, 86, 852-62.

9. Allred, B.J.; Tost, B.C. Laboratory comparison of four iron-based filter materials for water treatment of trace element contaminants. Water Environ. Res. 2014, 86, 2221-2232.

10. Wang, H.; Wang, T.; Zhang, B.; Li, F.; Toure, B.; Omosa, I.B.; Chiramba, T.; Abdel-Monem, M.; Pradhan, M. Water and wastewater treatment in Africa - Current practices and challenges. CLEAN-Soil, Air, Water 2014, 42, 1029-1035. 
11. Momba, M.N.B.; Obi, C.L.; Thompson, P. Survey of disinfection efficiency of small drinking water treatment plants: Challenges facing small water treatment plants in South Africa. Water SA 2009, 35, 485-494.

12. Frechen, F.-B.; Exler, H.; Romaker, J.; Schier, W. Long-term behaviour of a gravity-driven dead end membrane filtration unit for potable water supply in cases of disasters. Water Sci. Technol. Water Supply 2011, 11, 39-44.

13. Ali, I. Water treatment by adsorption columns: Evaluation at ground level. Sep. Purif. Rev. 2014, 43, 175-205.

14. Hussam, A.; Munir, A.K.M. A simple and effective arsenic filter based on composite iron matrix: Development and deployment studies for groundwater of Bangladesh. J. Environ. Sci. Health A 2007, 42, 1869-1878.

15. Ngai, T.K.K.; Shrestha, R.R.; Dangol, B.; Maharjan, M.; Murcott, S.E. Design for sustainable development - Household drinking water filter for arsenic and pathogen treatment in Nepal. $J$. Environ. Sci. Health A 2007, 42, 1879-1888.

16. Noubactep, C.; Schöner, A.; Woafo, P. Metallic iron filters for universal access to safe drinking water. Clean: Soil, Air, Water 2009, 37, 930-937.

17. Noubactep, C. Metallic iron for safe drinking water worldwide. Chem. Eng. J. 2010, 165, 740749.

18. Chiu, P.C. Applications of zero-valent iron (ZVI) and nanoscale ZVI to municipal and decentralized drinking water systems - A review. In Novel Solutions to Water Pollution, Ahuja S. and Hristovski K. (Eds), ACS Symposium Series, Vol. 1123; American Chemical Society: Washington, DC, doi: 10.1021/bk-2013-1123.ch014, 2013, pp 237-249.

19. Schäfer, A.I.; Broeckmann, A.; Richards, B.S. Renewable energy powered mem-brane technology. 1. Development and characterization of a photovoltaic hybrid membrane system. Environ. Sci. Technol. 2007, 41, 998-1003. 
20. Schäfer, A.I.; Hughes, G.; Richards, B.S. Renewable energy powered membrane technology: A leapfrog approach to rural water treatment in developing countries? Renew. Sust. Energy Rev. 2014, 40, 542-556.

21. Johnson, D.M.; Hokanson, D.R.; Zhang, Q.; Czupinski, K.D.; Tang, J. Feasibility of water purification technology in rural areas of developing countries. J. Environ. Manage. 2008, 88, $416-427$.

22. Litter, M.I.; Morgada, M.E.; Bundschuh, J. Possible treatments for arsenic removal in Latin American waters for human consumption. Environ. Pollut. 2010, 158, 1105-1118.

23. Giles, D.E.; Mohapatra, M.; Issa, T.B.; Anand, S.; Singh, P. Iron and aluminium based adsorption strategies for removing arsenic from water. J. Environ. Manage. 2011, 92, 30113022 .

24. Gottinger, A.M.; McMartin, D.W.; Wild, D.J.; Moldovan, B. Integration of zero valent iron sand beds into biological treatment systems for uranium removal from drinking water wells in rural Canada. Can. J. Civ. Eng. 2013, 40, 945-950.

25. Domga, R.; Togue-Kamga, F.; Noubactep, C.; Tchatchueng, J.-B. Discussing porosity loss of $\mathrm{Fe}^{0}$ packed water filters at ground level. Chem. Eng. J. 2015, 263, 127-134.

26. Kowalski, K. New method for arsenic compounds elimination from naturally contaminated drinking water systems. Dissertation, Aalborg Universitet, Denmark, 2014.

27. Kowalski, K.P.; Søgaard, E.G. Implementation of zero-valent iron (ZVI) into drinking water supply - Role of the ZVI and biological processes. Chemosphere 2014, 117, 108-114.

28. Noubactep, C.; Schöner, A. Metallic iron for environmental remediation: Learning from electrocoagulation. J. Hazard. Mater. 2010, 175, 1075-1080.

29. Bojic, A.; Purenovic, M.; Kocic, B.; Perovic, J.; Ursic-Jankovic, J.; Bojic, D. The inactivation of Escherichia coli by microalloyed aluminium based composite. Facta Universitatis 2001, 2, 115-124. 
30. Bojic, A.; Purenovic, M.; Bojic, D. Removal of chromium(VI) from water by micro-alloyed aluminium based composite in flow conditions. Water SA 2004, 30, 353-359.

31. Bojic, A.Lj.; Purenovic, M.; Bojic, D.; Andjelkovic, T. Dehalogenation of trihalomethanes by a micro-alloyed aluminium composite under flow conditions. Water SA 2007, 33, 297-304.

32. Bojic, A.Lj.; Bojic, D.; Andjelkovic, T. Removal of $\mathrm{Cu}^{2+}$ and $\mathrm{Zn}^{2+}$ from model wastewaters by spontaneous reduction-coagulation process in flow conditions. J. Hazard. Mater. 2009, 168, 813-819.

33. Lackovic, J.A.; Nikolaidis, N.P.; Dobbs, G.M. Inorganic arsenic removal by zero-valent iron. Environ. Eng. Sci. 2000, 17, 29-39.

34. Scherer, M.M.; Richter, S.; Valentine, R.L.; Alvarez, P.J.J. Chemistry and microbiology of permeable reactive barriers for in situ groundwater clean up. Rev. Environ. Sci. Technol. 2000, $30,363-411$.

35. Mantha, R.; Taylor, K.E.; Biswas, N.; Bewtra, J.K. A continuous system for $\mathrm{Fe}^{0}$ reduction of nitrobenzene in synthetic wastewater. Environ. Sci. Technol. 2001, 35, 3231-3236.

36. You, Y.; Han, J.; Chiu, P.C.; Jin, Y. Removal and inactivation of waterborne viruses using zerovalent iron. Environ. Sci. Technol. 2005, 39, 9263-9269.

37. Diao, M.; Yao, M. Use of zero-valent iron nanoparticles in inactivating microbes. Water Res. 2009, 43, 5243-5251.

38. Noubactep, C. On the mechanism microbe inactivation by metallic iron. J. Hazard. Mater. 2011, 198, 383-386.

39. Shi, C.; Wie, J.; Jin, Y.; Kniel, K.E.; Chiu, P.C. Removal of viruses and bacteriophages from drinking water using zero-valent iron. Sep. Purif. Technol. 2012, 84, 72-78.

40. Cheng, R.; Li, G.; Cheng, C.; Liu, P.; Shi, L.; Ma, Z.; Zheng, X. Removal of bacteriophage f2 in water by nanoscale zero-valent iron and parameters optimization using response surface methodology. Chem. Eng. J. 2014, 252, 150-158. 
41. Wu, D.; Zheng, S.; Ding, A.; Sun, G.; Yang, M. Performance of a zero valent iron-based anaerobic system in swine wastewater treatment. J. Hazard. Mater. 2015, 286, 1-6.

42. Yang, M.; Hashimoto, T.; Hoshi, N.; Myoga H. Fluoride removal in a fixed bed packed with granular calcite. Water Res. 1999, 33, 3395-3402.

43. Meenakshi; Maheshwari, R.C. Fluoride in drinking water and its removal. J. Hazard. Mater. 2006, 137, 456-463.

44. García, M.G.; Borgnino, L.; Bia, G.; Depetris, P.J. Mechanisms of arsenic and fluoride release from Chacopampean sediments (Argentina). Int. J. Environ. Health 2014, 7, 41-57.

45. Trikha, R.; Sharma, B.K. Studies on factors affecting fluoride removal from water using passive system. J. Environ. Chem. Eng. 2014, 2, 172-176.

46. Omenka, E. Improvement of Decentralised Wastewater Treatment in Asaba, Nigeria. Master's Thesis, Lund University, Sweden, 100 pp, 2010.

47. Younos, T. Paradigm shift: Holistic approach for water management in urban environments. Frontiers Earth Sci. 2011, 5, 421-427.

48. Hussam, A. Contending with a Development Disaster: SONO Filters Remove Arsenic from Well Water in Bangladesh. Innovations 2009, 4, 89-102.

49. Noubactep, C. Affordable safe drinking water for victims of natural disasters. In Kätsch C., and Meliczek H. (Eds) "Natural Disasters and Sustainable Development", Proceedings of the International Seminar held in Göttingen, Germany 17-19 April 2013, Cuvillier Verlag, Göttingen; ISBN-13: 9783954046683, 2014, pp. 57-75.

50. Khan, A.H.; Rasul, S.B.; Munir, A.K.M.; Habibuddowla, M.; Alauddin, M.; Newaz, S.S.; Hussam, A. Appraisal of a simple arsenic removal method for groundwater of bangladesh. $J$. Environ. Sci. Health A 2000, 35, 1021-1041.

51. Antia, D.D.J. Modification of aquifer pore-water by static diffusion using nano-zero-valent metals. Water 2011, 3, 79-112. 
52. Gottinger, A.M.; Wild, D.J.; McMartin, D.; Moldovan, B.; Wang, D. Development of an ironamended biofilter for removal of arsenic from rural Canadian prairie potable water. In: Water Pollution X. A.M. Marinov and C.A. Brebbia, Eds.; WIT Press: Ashurst, Southampton, 2010, 2010, 333-344.

53. Neumann, A.; Kaegi, R.; Voegelin, A.; Hussam, A.; Munir, A.K.M.; Hug, S.J., Arsenic removal with composite iron matrix filters in Bangladesh: A field and laboratory study. Environ. Sci. Technol. 2013, 47, 4544-4554.

54. Trois, C.; Cibati, A. South African sands as a low cost alternative solution for arsenic removal from industrial effluents in permeable reactive barriers: Column tests. Chem. Eng. J. 2015, 259, 981-989.

55. Gillham, R.W.; O’Hannesin, S.F. Enhanced degradation of halogenated aliphatics by zerovalent iron. Ground Water 1994, 32, 958-967.

56. Matheson, L.J.; Tratnyek, P.G. Reductive dehalogenation of chlorinated methanes by iron metal. Environ. Sci. Technol. 1994, 28, 2045-2053.

57. Weber, E.J. Iron-mediated reductive transformations: investigation of reaction mechanism. Environ. Sci. Technol. 1996, 30, 716-719.

58. O'Hannesin, S.F.; Gillham, R.W. Long-term performance of an in situ "iron wall" for remediation of VOCs. Ground Water 1998, 36, 164-170.

59. Sarr, D. Zero-valent-iron permeable reactive barriers - how long will they last? Remediation 2001, 11, 1-18.

60. Murugan, S.; Paulpandian, P. Synergistic antibacterial evaluation of commercial antibiotics combined with nanoiron against human pathogens. Int. J. Pharm. Sci. Rev. Res. 2013, 18, 183190.

61. Henderson, A.D.; Demond A.H. Long-term performance of zero-valent iron permeable reactive barriers: a critical review. Environ. Eng. Sci. 2007, 24, 401-423. 
62. Bartzas, G.; Komnitsas, K. Solid phase studies and geochemical modelling of low-cost permeable reactive barriers. J. Hazard. Mater. 2010, 183, 301-308.

63. Li, L.; Benson, C.H. Evaluation of five strategies to limit the impact of fouling in permeable reactive barriers. J. Hazard. Mater. 2010, 181, 170-180.

64. Comba, S.; Di Molfetta, A.; Sethi, R. A Comparison between field applications of nano-, micro-, and millimetric zero-valent iron for the remediation of contaminated aquifers. Water Air Soil Pollut. 2011, 215, 595-607.

65. Crane, R.A.; Dickinson, M.; Popescu, I.C.; Scott T.B. Magnetite and zero-valent iron nanoparticles for the remediation of uranium contaminated environmental water. Water Res. 2011, 45, 2931-2942.

66. Gheju, M. Hexavalent chromium reduction with zero-valent iron (ZVI) in aquatic systems. Water Air Soil Pollut. 2011, 222, 103-148.

67. Scott, T.B.; Popescu, I.C.; Crane, R.A.; Noubactep, C. Nano-scale metallic iron for the treatment of solutions containing multiple inorganic contaminants. J. Hazard. Mater. 2011, $186,280-287$.

68. Allred, B.J. Laboratory evaluation of porous iron composite for agricultural drainage water filter treatment. Transactions ASABE 2012, 55, 1683-1697.

69. Allred, B.J. Laboratory evaluation of zero valent iron and sulfur-modified iron for agricultural drainage water treatment. Ground Water Monit. Remediat. 2012, 32, 81-95.

70. Crane, R.A.; Noubactep. Elemental metals for environmental remediation: lessons from hydrometallurgy. Fresen. Env. Bull. 2012, 21, 1192-1196.

71. Crane, R.A.; Scott T.B. Nanoscale zero-valent iron: Future prospects for an emerging water treatment technology. J. Hazard. Mater. 2012, 211-212, 112-125.

72. Noubactep, C.; Caré, S.; Crane, R.A. Nanoscale metallic iron for environmental remediation: prospects and limitations. Water Air Soil Pollut. 2012, 223, 1363-1382. 
73. Yoshino, H.; Kawase, Y. Kinetic modeling and simulation of zero-valent iron wastewater treatment process: simultaneous reduction of nitrate, hydrogen peroxide, and phosphate in semiconductor acidic wastewater. Ind. Eng. Chem. Res., 2013, 52, 17829-17840.

74. Crane, R.A.; Scott T.B. The removal of uranium onto nanoscale zero-valent iron particles in anoxic batch systems. J. Nanomater. 2014, 2014, 1-9. doi:10.1155/2014/956360

75. Fu, F.; Dionysiou, D.D.; Liu, H. The use of zero-valent iron for groundwater remediation and wastewater treatment: A review. J. Hazard. Mater. 2014, 267, 194-205.

76. Vodyanitskii Yu.N. Effect of reduced iron on the degradation of chlorinated hydrocarbons in contaminated soil and ground water: A review of publications. Eurasian Soil Sci. 2014, 47, $119-133$.

77. Vodyanitskii, Yu.N. Artificial permeable redox barriers for purification of soil and ground water: A review of publications. Eurasian Soil Sci. 2014, 47, 1058-1068.

78. Crane, R.A.; Dickinson, M.; Scott T.B. Nanoscale zero-valent iron particles for the remediation of plutonium and uranium contaminated solutions. Chem. Eng. J. 2015, 262, 319-325.

79. Naidu, R.; Birke, V. Permeable reactive barrier: sustainable groundwater remediation. CRC Press, 2015, 333 pp., ISBN 9781482224474.

80. Ghauch, A.; Abou Assi, H.; Bdeir, S. Aqueous removal of diclofenac by plated elemental iron: Bimetallic systems. J. Hazard. Mater. 2010, 182, 64-74.

81. Ghauch, A.; Abou Assi, H.; Baydoun, H.; Tuqan, A.M.; Bejjani, A. Fe ${ }^{0}$-based trimetallic systems for the removal of aqueous diclofenac: Mechanism and kinetics. Chem. Eng. J. 2011, $172,1033-1044$.

82. Ghauch, A. Iron-based metallic systems: An excellent choice for sustainable water treatment. Habilitation Thesis, University of Grenoble, France, 2013.

83. Lai, K.C.K.; Lo, I.M.C.; Birkelund, V.; Kjeldsen, P. Field monitoring of a permeable reactive barrier for removal of chlorinated organics. J. Environ. Eng. 2006, 132, 199-210. 
84. Jia, Y.; Aagaard, P.; Breedveld, G.D. Sorption of triazoles to soil and iron minerals. Chemosphere 2007, 67, 250-258.

85. Noubactep, C. Characterizing the discoloration of methylene blue in $\mathrm{Fe}^{0} / \mathrm{H}_{2} \mathrm{O}$ systems. $J$. Hazard. Mater. 2009, 166, 79-87.

86. Zhang, W.-x. Nanoscale iron particles for environmental remediation: An overview. $J$. Nanopart. Res. 2003, 5, 323-332.

87. Korte, N.E.; Zutman, J.L.; Schlosser, R.M.; Liang, L.; Gu, B.; Fernando, Q. Field application of palladized iron for the dechlorination of trichloroethene. Waste Manage 2000, 20, 687-694.

88. Huang, Y.H.; Tang, C.L.; Zeng, H. Removing molybdate from water using a hybridized zerovalent iron/magnetite/Fe(II) treatment system. Chem. Eng. J. 2012, 200, 205-263.

89. Huang, Y.H.; Peddi, P.K.; Zeng, H.; Tang, C.L.; Teng, X.J. Pilot-scale demonstration of the hybrid zero-valent iron process for treating flue-gas-desulfurization wastewater: Part I. Water Sci. Technol 2013, 67, 16-23.

90. Huang, Y.H.; Peddi, P.K.; Zeng, H.; Tang, C.L.; Teng, X.J. Pilot-scale demonstration of the hybrid zero-valent iron process for treating flue-gas-desulfurization wastewater: Part II. Water Sci. Technol. 2013, 67, 239-246.

91. Arnold, W.A.; Roberts, A.L. Pathways of chlorinated ethylene and chlorinated acetylene reaction with Zn(0). Environ. Sci. Technol. 1998, 32, 3017-3025.

92. Arnold, W.A.; Ball, W.P.; Roberts, A.L. Polychlorinated ethane reaction with zero-valent zinc: pathways and rate control. J. Contam. Hydrol. 1999, 40, 183-200.

93. Suresh, S. Reductive remediation of pollutants using metals. Open Waste Manage. J. 2009, 2, 6-16.

94. Salter-Blanc, A.J.; Tratnyek, P.G. Effects of solution chemistry on the dechlorination of 1,2,3trichloropropane by zero-valent zinc. Environ. Sci. Technol. 2011, 45, 4073-4079.

95. Han, V.; Chen, Z.-1.; Tong, L.-n.; Yang, L.; Shen, J.-m.; Wang, B.-y.; Liu, Y.; Liu, Y.; Chen, Q. Reduction of N-Nitrosodimethylamine with zero-valent zinc. Water Res. 2013, 47, 216-224. 
96. Dickerson, R.E.; Gray, H.B.; Haight Jr., G.P. Chemical Principles, 3. Edition, Benjamin/Cummings Inc. London, Amsterdam, 1979, 944 pp.

97. Noubactep, C. The suitability of metallic iron for environmental remediation. Environ. Progr. Sust. En. 2010, 29, 286-291.

98. Rahman, M.A.; Karmakar, S.; Salama, H.; Gactha-Bandjun, N.; Btatkeu-K., B.D.; Noubactep C. Optimising the design of $\mathrm{Fe}^{0}$-based filtration systems for water treatment: The suitability of porous iron composites. J. Appl. Solution Chem. Modeling 2013, 2, 165-177.

99. Gillham, R.W. Discussion of Papers/Discussion of nano-scale iron for dehalogenation. by Evan K. Nyer and David B. Vance (2001), Ground Water Monitoring \& Remediation, v. 21, no. 2, pages 41-54. Ground Water Monit. Remed. 2003, 23, 6-8.

100. Caré, S.; Crane, R.; Calabro, P.S.; Ghauch, A.; Temgoua, E.; Noubactep, C. Modelling the permeability loss of metallic iron water filtration systems. Clean - Soil, Air, Water 2013, $41,275-282$.

101. Sato, N. 1989 Whitney Award Lecture: Toward a more fundamental understanding of corrosion processes. Corrosion 1989, 45, 354-368.

102. Stratmann, M.; Müller, J. The mechanism of the oxygen reduction on rust-covered metal substrates. Corros. Sci. 1994, 36, 327-359.

103. Sato, N. Surface oxides affecting metallic corrosion. Corros. Rev. 2001, 19, 253-272.

104. Nesic, S. Key issues related to modelling of internal corrosion of oil and gas pipelines A review. Corros. Sci. 2007, 49, 4308-4338.

105. Dickinson, M.; Scott, T.B.; Crane, R.A.; Riba, O.; Barnes, R.J.; Hughes, G.M. The effects of vacuum annealing on the structure and surface chemistry of iron:nickel alloy nanoparticles. J. Nano. Res. 2010, 12, 2081-2092. 
106. Scott, T.B.; Dickinson, M.; Crane, R.A.; Riba, O.; Hughes, G.M.; Allen, G.C. The effects of vacuum annealing on the structure and surface chemistry of iron nanoparticles. $J$. Nano. Res. 2010, 12, 1765-1775.

107. Caule, E.J.; Cohen, M. An electron-micrograph study of oxide films on electropolished surfaces of iron. Can. J. Chem. 1953, 31, 237-241.

108. Cohen, M. The formation and properties of passive films on iron. Can. J. Chem. 1959, $37,286-291$.

109. Sikora, E.; Macdonald, D.D. The passivity of iron in the presence of ethylenediaminetetraacetic acid I. General electrochemical behavior. J. Electrochem. Soc. 2000, 147, 4087-4092.

110. Gheju, M.; Balcu, I. Removal of chromium from $\operatorname{Cr}(\mathrm{VI})$ polluted wastewaters by reduction with scrap iron and subsequent precipitation of resulted cations. J. Hazard. Mater. 2011, 196, 131-138.

111. Noubactep, C. A critical review on the mechanism of contaminant removal in $\mathrm{Fe}^{0}-\mathrm{H}_{2} \mathrm{O}$ systems. Environ. Technol. 2008, 29, 909-920.

112. Noubactep, C. Metallic iron for water treatment: A critical review. Clean - Soil, Air, Water 2013, 41, 702-710.

113. Noubactep, C.; Schöner, A.; Sauter, M. Significance of oxide-film in discussing the mechanism of contaminant removal by elemental iron materials. In "Photo-Electrochemistry \& Photo-Biology for the Sustainablity"; S. Kaneco, B. Viswanathan, H. Katsumata (Eds.), Union Press, ISBN-10: 4946428615; ISBN-13: 978-4946428616, 2012, pp. 97-122.

114. Noubactep, C. Processes of contaminant removal in " $\mathrm{Fe}^{0}-\mathrm{H}_{2} \mathrm{O}$ " systems revisited. The importance of co-precipitation. Open Environ. Sci. 2007, 1, 9-13.

115. Noubactep, C. An analysis of the evolution of reactive species in $\mathrm{Fe}^{0} / \mathrm{H}_{2} \mathrm{O}$ systems. $J$. Hazard. Mater. 2009, 168, 1626-1631. 
116. Noubactep, C. The fundamental mechanism of aqueous contaminant removal by metallic iron. Water $S A$ 2010, 36, 663-670.

117. Noubactep, C. Aqueous contaminant removal by metallic iron: Is the paradigm shifting? Water SA 2011, 37, 419-426.

118. Noubactep, C. Relevant reducing agents in remediation $\mathrm{Fe}^{0} / \mathrm{H}_{2} \mathrm{O}$ systems. Clean: Soil, Air, Water 2013, 41, 493-502.

119. Jiao, Y.; Qiu, C.; Huang, L.; Wu, K.; Ma, H.; Chen, S.; Ma, L.; Wu, L. Reductive dechlorination of carbon tetrachloride by zero-valent iron and related iron corrosion. Appl. Catal. B: Environ. 2009, 91, 434-440.

120. Noubactep, C. Metallic iron for safe drinking water production. Freiberg Online Geoscience 2011, 27, 38 pp. ISSN 1434-7512.

121. Noubactep, C.; Temgoua, E.; Rahman, M.A. Designing iron-amended biosand filters for decentralized safe drinking water provision. CLEAN - Soil, Air, Water 2012, 40, 798-807.

122. Noubactep, C. Flaws in the design of $\mathrm{Fe}(0)$-based filtration systems? Chemosphere 2014, 117, 104-107.

123. Noubactep, C. Designing metallic iron packed-beds for water treatment: A critical review. Clean - Soil, Air, Water 2015, doi:10.1002/clen.201400304.

124. Westerhoff, P.; James, J. Nitrate removal in zero-valent iron packed columns. Water Res. 2003, 37, 1818-1830.

125. Ruhl, A.S.; Ünal, N.; Jekel, M. Evaluation of two-component $\mathrm{Fe}(0)$ fixed bed filters with porous materials for reductive dechlorination. Chem. Eng. J. 2012, 209, 401-406.

126. Ruhl, A.S. Martin, J. Impacts of $\mathrm{Fe}(0)$ grain sizes and grain size distributions in permeable reactive barriers. Chem. Eng. J. 2012, 213, 245-250.

127. Bi, E.; Devlin, J.F.; Huang, B. Effects of mixing granular iron with sand on the kinetics of trichloroethylene reduction. Ground Water Monit. Remed. 2009, 29, 56-62. 
128. Ulsamer, S. A model to characterize the kinetics of dechlorination of tetrachloroethylene and trichloroethylene by a zero valent iron permeable reactive barrier. Master thesis, Worcester Polytechnic Institute, 2011, 73 pp.

129. Firdous, R.; Devlin, J.F. Consideration of grain packing in granular iron treatability studies. J. Contam. Hydrol. 2014, 164, 230-239.

130. Noubactep, C.; Caré S. Dimensioning metallic iron beds for efficient contaminant removal. Chem. Eng. J. 2010, 163, 454-460.

131. Noubactep, C.; Caré S. Designing laboratory metallic iron columns for better result comparability. J. Hazard. Mater. 2011, 189, 809-813.

132. Btatkeu-K., B.D.; Miyajima, K.; Noubactep, C.; Caré, S. Testing the suitability of metallic iron for environmental remediation: Discoloration of methylene blue in column studies. Chem. Eng. J. 2013, 215-216, 959-968.

133. Noubactep, C.; Meinrath, G.; Dietrich, P.; Sauter, M.; Merkel, B. Testing the suitability of zerovalent iron materials for reactive walls. Environ. Chem. 2005, 2, 71-76.

134. Noubactep, C.; Licha, T.; Scott, T.B.; Fall, M.; Sauter, M. Exploring the influence of operational parameters on the reactivity of elemental iron materials. J. Hazard. Mater. 2009, 172, 943-951.

135. Miyajima, K. Optimizing the design of metallic iron filters for water treatment. Freiberg Online Geosci. 2012, 32, 60 pp.

136. Phukan, M. Characterizing the $\mathrm{Fe}^{0} /$ sand system by the extent of dye discoloration. Master thesis University of Göttingen, 2015.

137. Caré, S.; Nguyen, Q.T.; L'Hostis, V.; Berthaud, Y. Mechanical properties of the rust layer induced by impressed current method in reinforced mortar. Cement Concrete Res. 2008, 38, 1079-1091.

138. Gillham, R.W. Development of the granular iron permeable reactive barrier technology (good science or good fortune). In "Advances in environmental geotechnics : proceedings of 
the International Symposium on Geoenvironmental Engineering in Hangzhou, China, September 8-10, 2009"; Y. Chen, X. Tang, L. Zhan (Eds); Springer Berlin/London, 2010, pp. $5-15$.

139. Phillips, D.H.; Van Nooten, T.; Bastiaens, L.; Russell, M.I.; Dickson, K.; Plant, S.; Ahad, J.M.E.; Newton, T.; Elliot, T.; Kalin, R.M. Ten year performance evaluation of a fieldscale zero-valent iron permeable reactive barrier installed to remediate trichloroethene contaminated groundwater. Environ. Sci. Technol. 2010, 44, 3861-3869.

140. Wilkin, R.T.; Acree, S.D.; Ross, R.R.; Puls, R.W.; Lee, T.R.; Woods, L.L. Fifteen-year assessment of a permeable reactive barrier for treatment of chromate and trichloroethylene in groundwater. Sci. Tot. Environ. 2014, 468-469, 186-194.

141. Morrison, S.J.; Mushovic, P.S.; Niesen, P.L. Early Breakthrough of Molybdenum and Uranium in a Permeable Reactive Barrier. Environ. Sci. Technol. 2006, 40, 2018-2024.

142. Landis, R.L.; Gillham, R.W.; Reardon, E.J.; Fagan, R.; Focht, R.M.; Vogan, J.L. An examination of zero-valent iron sources used in permeable reactive barriers. 3rd International Containment Technology Conference (10-13 June 2001), Florida State University, Tallahassee. Orlando, FL. 2001, 5 pages.

143. Miehr, R.; Tratnyek, G.P.; Bandstra, Z.J.; Scherer, M.M.; Alowitz, J.M.; Bylaska, J.E. Diversity of contaminant reduction reactions by zerovalent iron: Role of the reductate. Environ. Sci. Technol. 2004, 38, 139-147.

144. Johnson, T.L.; Scherer, M.M.; Tratnyek. P.G. Kinetics of halogenated organic compound degradation by iron metal. Environ. Sci. Technol. 1996, 30, 2634-2640.

145. McGeough, K.L.; Kalin, R.M.; Myles, P. Carbon disulfide removal by zero valent iron. Environ. Sci. Technol. 2007, 41, 4607-4612.

146. Yao, K.-M.; Habibian, M.T.; O'melia, C.R. Water and waste water filtration: concepts and applications. Environ. Sci. Technol. 1971, 5, 1105-1112. 
147. Bedrikovetsky, P.; Siqueira, F.D.; Furtado, C.A.; Souza, A.L.S. Modified particle detachment model for colloidal transport in porous media. Transp. Porous Med. 2011, 86, 353383.

148. You, Z.; Osipov, Y.; Bedrikovetsky, P.; Kuzmina, L. Asymptotic model for deep bed filtration. Chem. Eng. J. 2014, 258, 374-385.

149. Noubactep, C.; Meinrath, G.; Dietrich, P.; Merkel, B. Mitigating uranium in ground water: prospects and limitations. Environ. Sci. Technol. 2003, 37, 4304-4308.

150. Noubactep, C.; Meinrath, G.; Merkel, J.B. Investigating the mechanism of uranium removal by zerovalent iron materials. Environ. Chem. 2005, 2, 235-242.

151. Noubactep, C.; Schöner, A.; Meinrath, G. Mechanism of uranium (VI) fixation by elemental iron. J. Hazard. Mater. 2006, 132, 202-212.

152. Lackovic, J.A.; Nikolaidis, N.P.; Dobbs, G.M. Inorganic arsenic removal by zero-valent iron. Environ. Eng. Sci. 2000, 17, 29-39.

153. Farrell, J.; Wang, J.; O'Day, P.; Conklin, M. Electrochemical and spectroscopic study of arsenate removal from water using zero-valent iron media. Environ. Sci. Technol. 2001, 35, 2026-2032.

154. Mantha, R.; Taylor, K.E.; Biswas, N.; Bewtra, J.K. A continuous system for Fe reduction of nitrobenzene in synthetic wastewater. Environ. Sci. Technol. 2001, 35, 3231-3236.

155. Furukawa, Y.; Kim, J.-W.; Watkins, J.; Wilkin, R.T. Formation of ferrihydrite and associated iron corrosion products in permeable reactive barriers of zero-valent iron. Environ. Sci. Technol. 2002, 36, 5469-5475.

156. Miyajima, K.; Noubactep, C. Impact of $\mathrm{Fe}^{0}$ amendment on methylene blue discoloration by sand columns. Chem. Eng. J. 2013, 217, 310-319. 
157. Miyajima, K.; Noubactep, C. Characterizing the impact of sand addition on the efficiency of granular iron for water treatment. Chem. Eng. J. 2015, 262, 891-896.

158. Btatkeu-K., B.D.; Olvera-Vargas, H.; Tchatchueng, J.B.; Noubactep, C.; Caré, S. (2014): Determining the optimum $\mathrm{Fe}^{0}$ ratio for sustainable granular $\mathrm{Fe}^{0} /$ sand water filters Chem. Eng. J. 2014, 247, 265-274.

159. Btatkeu-K., B.D.; Olvera-Vargas, H.; Tchatchueng, J.B.; Noubactep, C.; Caré, S. Characterizing the impact of $\mathrm{MnO}_{2}$ on the efficiency of $\mathrm{Fe}^{0}$-based filtration systems. Chem. Eng. J. 2014, 250, 416-422.

160. Phukan, M.; Noubactep, C.; Licha, T. Characterizing the ion-selective nature of $\mathrm{Fe}^{0}-$ based filters using azo dyes. Chem. Eng. J. 2015, 259, 481-491.

161. Badruzzaman, M.; Westerhoff, P. The application of rapid small-scale column tests in iron-based packed bed arsenie treatment systems. Advances in Arsenic Research, Chapter 19, 2005, 268-283 (ACS Symposium Series, Volume 915, DOI: 10.1021/bk-2005-0915.ch019).

162. Gu, B.; Phelps, T.J.; Liang, L.; Dickey, M.J.; Roh, Y.; Kinsall, B.L.; Palumbo, A.V.; Jacobs, G.K. Biogeochemical dynamics in zero-valent iron columns: implications for permeable reactive barriers. Environ. Sci. Technol. 1999, 33, 2170-2177.

163. Farrell, J.; Kason, M.; Melitas, N.; Li, T. Investigation of the long-term performance of zero-valent iron for reductive dechlorination of trichloroethylene. Environ. Sci. Technol. 2000, $34,514-521$.

164. Melitas, N.; Wang, J.P.; Conklin, M.; O’Day, P.; Farrell, J. Understanding soluble arsenate removal kinetics by zerovalent iron media. Environ. Sci. Technol. 2002, 36, 2074 2081. 
165. Bilardi, S.; Calabrò, P.S.; Moraci, N., Are accelerated column tests used in permeable reactive barriers design sufficiently reliable? Proceeding of the third international conference "Hazardous and industrial waste management". 12-14 Septembre 2012, 2012, Create, Greece.

166. Moraci, N.; Bilardi, S.; Calabrò, P. Critical aspects related to $\mathrm{Fe}^{0}$ and $\mathrm{Fe}^{0}$ /pumice $\mathrm{PRB}$ design. Environ. $\quad$ Geotechnics $2014, \quad$ Paper http://dx.doi.org/10.1680/envgeo.13.00120.

167. Kyzas, G.Z.; Fu, J.; Matis, K.A. The change from past to future for adsorbent materials in treatment of dyeing wastewaters. Materials 2013, 6, 5131-5158.

168. Dawood, S.; Sen, T.K.. Review on dye removal from its aqueous solution into alternative cost effective and non-conventional adsorbents. J. Chem. Proc. Engg. 2014, 1, 111.

169. Chapman, A.C.; Siebold, A. On the application of adsorption to the detection and separation of certain dyes. Analyst 1912, 37, 339-345.

170. Ewing, W.W.; Liu, F.W.J. Adsorption of dyes from aqueous solutions on pigments. $J$. Colloid Sci. 1953, 8, 204-213.

171. Whetstone, J. The adsorption of dyes by crystals. Discuss. Faraday Soc. 1954, 16, $132-$ 140.

172. Haldeman, R.G.; Emmett, P.H. Specific adsorption of alkyl orange dyes on silica gel. $J$. Phys. Chem. 1955, 59, 1039-1043.

173. Mitchell, G.; Poole, P.; Segrove, H.D. Adsorption of methylene blue by high-silica sands. Nature 1955, 176, 1025-1026.

174. Prasad, R.; Dey, A.K. Adsorption of dyestuffs by hydrous thorium oxide: Heat of adsorption of the dyes by various samples of the hydroxide. Kolloid Z. Z. Polym. 1962, 183, 153-155. 
175. Brooks, C.S. Mechanism of methylene blue dye adsorption on siliceous minerals. Kolloid Z. Z. Polym. 1964, 199, 31-36.

176. Padday, J.F. Adsorption of cyanine dyes at silver-halide surfaces. Trans. Faraday Soc. 1964, 60, 1325-1334.

177. Crittenden, J.C.; Luft, C.P.; Hand, D.W. Prediction of multicomponent adsorption equilibria in background mixtures of unknown composition. Water Res. 1985, 19, 1537-1548.

178. Worch, E. Fixed-bed adsorption in drinking water treatment: a critical review on models and parameter estimation. J. Water Supply Res. Technol. - AQUA 2008, 57, 171-183.

179. Xu, Z.; Cai, J.-g.; Pan, B.-c. Mathematically modeling fixed-bed adsorption in aqueous systems. J. Zhejiang Univ-Sci. A 2013, 14, 155-176.

180. Nitzsche, K.S.; Lan, V.M.; Trang, P.T.K.; Viet, P.H.; Berg, M.; Voegelin, A.; PlanerFriedrich, B.; Zahoransky, J.; Müller, S.-K.; Byrne, J.M.; Schröder, C.; Behrens, S.; Kappler, A. Arsenic removal from drinking water by a household sand filter in Vietnam - Effect of filter usage practices on arsenic removal efficiency and microbiological water quality. Sci. Tot. Environ. 2015, 502, 526-536

181. Gatcha-Bandjun, N.; Noubactep, C.; Loura Mbenguela, B. Water treatment with $\mathrm{Fe}^{0} / \mathrm{H}_{2} \mathrm{O}$ systems: Learning from internal electrolysis. Fresenius Environ. Bull. 2014, 23, 2663 2669.

182. Burghardt, D.; Kassahun, A. Development of a reactive zone technology for simultaneous in situ immobilisation of radium and uranium. Environ. Geol. 2005, 49, 314-320.

183. Leupin, O.X.; Hug, S.J. Oxidation and removal of arsenic (III) from aerated groundwater by filtration through sand and zero-valent iron. Water Res. 2005, 39, 1729-740. 
184. Kearns, J. Sustainable decentralized water treatment for rural and developing communities using locally generated biochar adsorbents. Water Conditioning and Purification International 2012, 54, 7-12.

185. Tillman, D.E. Combination of zero-valent iron and granular activated for the treatment of groundwater contaminated with chlorinated solvents. Master thesis, Massachusetts Institute of Technology, 1996.

186. Indelicato, B.M. Comparision of zero-valent iron and activated carbon for treating chlorinated contaminants in groundwater. Master thesis, Massachusetts Institute of Technology, 1998.

187. Bayer, P.; Finkel, M. Modelling of sequential groundwater treatment with zero valent iron and granular activated carbon. J. Contam. Hydrol. 2005, 78, 129-146.

188. Van Nooten, T.; Diels, L.; Bastiaens, L. Design of a multifunctional permeable reactive barrier for the treatment of landfill leachate contamination: Laboratory column evaluation. Environ. Sci. Technol. 2008, 42, 8890-8895.

189. Doula, M.K. Simultaneous removal of $\mathrm{Cu}, \mathrm{Mn}$ and $\mathrm{Zn}$ from drinking water with the use of clinoptilolite and its Fe-modified form. Water Res. 2009, 43, 3659-3672.

190. Westholm, L.J.; Repo E.; Sillanpää, M. Filter materials for metal removal from mine drainage - a review. Environ. Sci. Pollut. Res. 2014, 21, 9109-9128.

191. Kosmulski, M. The pH-dependent surface charging and points of zero charge: V. Update. J. Colloid Interf. Sci. 2011, 353, 1-15.

192. Mohan, D.; Pittman Jr., C.U. Arsenic removal from water/wastewater using adsorbents A critical review. J. Hazard. Mater. 2007, 142, 1-53.

193. Gottinger, A.M. Chemical-free arsenic removal from potable water with a ZVIamended biofilter. Master thesis, University of Regina (Saskatchewan, Canada) 2010, 90 pp. 
194. Clark, P.A.; Pinedo, C.A.; Fadus, M.; Capuzzi, S. Slow-sand water filter: Design, implementation, accessibility and sustainability in developing countries. Med. Sci. Monit. 2012, 18, RA105-RA117.

195. Kearns, J. Sustainable decentralized water treatment for rural and developing communities using gasifier biochar Version 1.0, March 2012. 2012, Available at: http://www.aqsolutions.org/ (Access January $30^{\text {th }} 2015$ )

(C) 2014 by the authors; licensee MDPI, Basel, Switzerland. This article is an open access article distributed under the terms and conditions of the Creative Commons Attribution license (http://creativecommons.org/licenses/by/4.0/). 